

\section{DISCLAIMER}

This report was prepared as an account of work sponsored by an agency of the United States Government. Neither the United States Government nor any agency Thereof, nor any of their employees, makes any warranty, express or implied, or assumes any legal liability or responsibility for the accuracy, completeness, or usefulness of any information, apparatus, product, or process disclosed, or represents that its use would not infringe privately owned rights. Reference herein to any specific commercial product, process, or service by trade name, trademark, manufacturer, or otherwise does not necessarily constitute or imply its endorsement, recommendation, or favoring by the United States Government or any agency thereof. The views and opinions of authors expressed herein do not necessarily state or reflect those of the United States Government or any agency thereof. 


\section{DISCLAIMER}

Portions of this document may be illegible in electronic image products. Images are produced from the best available original document. 


\section{NOTICE}

This report was prepared as an account of work sponsored by the United States Government. Neither the United States nor the United States Energy Research and Development Administration, nor any of their employees, nor any of their contractors, subcontractors, or their employees, makes any warranty, express or implied, or assumes any legal liability or responsibility for the accuracy, completeness or usefulness of any information, apparatus, product or process disclosed, or represents that its use would not infringe privately owned rights.

This report has been reproduced directly from the best available copy.

Available from the National Technical Information Service, U. S. Department of Commerce, Springfield, Virginia 22161

$$
\begin{aligned}
& \text { Price: Paper Copy } \$ 6.75 \text { (domestic) } \\
& \$ 9.25 \text { (foreign) / 6. } 0 \\
& \text { Microfiche } \$ 3.00 \text { (domestic) } \\
& \$ 4.50 \text { (foreign) }
\end{aligned}
$$




\title{
TOTAL INTEGRATED ENERGY SYSTEM (TIES) FEASIBILITY ANALYSIS FOR THE DOWNTOWN REDEVELOPMENT PROJECT, PASADENA, CALIFORNIA
}

April 1977

Work Performed Under Contract No. EY-76-C-03-1151

\author{
City of Pasadena \\ Pasadena, California \\ Pasadena Redevelopment Agency \\ Pasadena, California \\ Levine and McCann \\ Los Angeles, California

\section{Genge Communtty Consultants \\ Los Angeles, California}

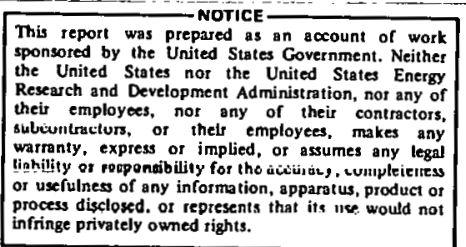

This report was prepared as an eccount of work

The United contractors. for the accuiral, comipleierires ents that its 115 would no 


\section{ACKNOWLEDGMENT}

The Feasibility Analysis of a Total Integrated Energy System (TIES) for the Downtown Redevelopment Project, Pasadena, California, was made possible by a contract from the United States Energy Research and Development Administration.

We wish to thank the following organizations and individuals who assisted us in the preparation and editing of this report:

John A. Martin \& Asșociates - Structural Engineers

Stanton Stockwell/Henningson Durham \& Richardson - Architects

Syska \& Hennessy Information Systems - Computer Analyses

Turner Construction Company - Cost Estimating and Scheduling

Gerald Leighton, Steve Cavros and John Rodousakis of ERDA,

Division of Buildings and Community Systems, Office of Conservation 


\section{contents}

I. INTRODUCTION
A. PURPOSE
$1-1$
B. BACKGROUND
C. DEFINITION OF SITE AND BUILDING DESIGN DATA
1. The Energy Using Community
2. Weather Data
3. Building Design and Usage

II. DEFINITION OF LOADS
A. COOLING, HEATING AND NON-HVAC LOADS

1. Required Services and Utilities

2. Analysis of Space Cooling and Heating Loads

3. Energy Analysis Computer Program

B. BUILDINO PEAK LOADS AND ANNUAL

$$
\text { ENERGY CONSUMPTION }
$$

III. DESCRIPTION OF CONVENTIONAL SYSTEM
A. DEFINITION OF CONVENTIONAL SYSTEM
III-1
B. ENE RGY CONSUMPTION
III-2
C. ANNUAL COSTS OF CONVENTIONAL SYSTEM
$|H| \cdot 2$

IV. DESCRIPTION OF CENTRAL COOLING/
HEATING PLANT SYSTEM

A. DEFINITION OF CENTRAL PLANT SYSTEM IV-1

B. ENERGY CONSUMPTION

IV.2

C. ANNUAL COSTS OF CENTRAL PLANT SYSTEM IV.2

V. EXAMINATION OF TIEE EYGTEMS

A. METHOD OF APPROACH V-1

1. Initial Examination of Energy Systcms and Project Constraints

2. Energy Cycle Relationships V.3

3. Ties Concept Advantages V.6

B. TIES SYSTEMS STUDIED $V \cdot 10$

1. Systeris Sludied : V.10

2. Energy Analysis of Ties Systems V.20

3. Other Axcess Input Parameters V.21

C. ENERGY CONSUMPTION OF TIES SYSTEMS STUDIED V-21

D. ANNUAL COSTS OF TIES SYSTEMS V.28

VI. DISCUSSION AND RECOMMENDATIONS •

A. COMPARISON OF TIES SYSTEMS WITH THE

CONVENTIONAL AND CENTRAL PLANT SYSTEMS VI-1

1. Eneigy Savings VI.1

2. Economic Fcasibility Comparison VI-1

3. Impact on Air Quality VI-3

B. COSTS OF GENERATING ELECTRICITY FOR

C. DISCUSSION OF SYSTEMS STUDIED VI.7

VII. GLOSSARY

V 1.7

\section{APPENDICES}




\section{list of figures}






\section{list of tables \\ NUMBER \\ page}

$11-1 \mathrm{a}$ ' $\mathrm{H}$ '-LOAD-COOLING AND HEATING LOADS

$11.1 \mathrm{~b}$ ' $H$ '-LOAD-COOLING AND HEATING LOADS

II.2 'H'-LOAD-COOLING LOAD 11.5

V.1 - GROUP 1-DIESEL ENGINE SYSTEM (WITH ABSORPTION

REFRIGERATION) $\quad$ V.12

V.2 GROUP 2-COMBUSTION TURBINE SYSTEM (WITH STEAM TURBINE DRIVEN CENTRIFUGAL REFRIGERATION)

V.3 GROUP 3-DESCRIPTION OF BOILER/STEAM TURBINE SYSTEM V-17

V-4 GROUP 4-COMBUSTION TURBINE SYSTEM IWITH BACKPRESSURF. STEAM TURBINE AND ABSORPTION REFRIGERATION) $\quad V-19$

V.5 GROUP 1-DIESEL ENGINE SYSTEM-ENERGY CONSUMPTION $\quad$ V.24

V.6 GROUP 2-GAS TURBINC/CENTRIFUGAL REFRIGERATION SYSTEM -ENERGY CONSUMPTION CONSUMPTION

V-8 GROUP 4-GAS TURBINE/ABSORPTION REFRIGERATION SYSTEM -ENERGY CONSUMPTION

V-9. CAPITAL COSTS

V-10 ANNUAL OPERATING COSTS

$V \cdot 27$

V.60

V.51

V.52

ANNUAL REVENUE

V.53

VI 1 COMPARIEON OF SYSTEM TNTRFY CONGUMPTION

VI.2

VI.2 . FEASIBILITY COMPARISON-TIES VS. CONVENTIONAL \& CENTRAL COOLING/HEATING PLANT

V.1-3

VI-3 ANNUAL EMISSIONS FROM PLANTS

VI.5

VI.4 COST OF GENERATING ELECTRICITY FOR TIES SCHEME

VI-6 
TOTAL INTEGRATED ENERGY SYSTEM

FEASIBILITY ANALYSIS FOR

THE DOWNTOWN REDEVELOPMENT PROJECT

PASADENA, CALIFORNIA

\section{INTRODUCTION}

\section{A. PURPOSE}

The purpose of this study is to determine the most desirable method of serving the energy needs of a commercial development to be constructed in Pasadena, California.

The factors that determine maximum desirability consist of the following:

1. Maximum economic benefit to the energy user and to the surrounding r.nmmiınity.

2. Minimum usage of energy by both the energy user and the surrounding community.

3. Minimum introduction of pollutants into the community.

The methods studied were the Total Integrated Energy System (TIES) concept in several configurations.

\section{B. BACKGROUND}

Several alternatives are available as methods of meeting a users total energy needs. The most common, however, is to acquire electric power from a serving utility company and to produce heating and cooling media; either through the use of electric power, or by firing a separate fuel in boilers, or by combinations of the two. Figure I-1a describes this "conventional" approach.

Assuming the utility company power plant is thermal in nature, losses of energy occur with in the plant due to radiation from plant equipment, cooling of plant equipment, non-recoverable stack losses, auxiliary power usage, and low potential heat rejection to atmosphere.

Within the user's facility, similar losses occur due to the energy conversion processes that take place. There also exists a transmission loss that occurs between the utility source and the user due to line impedance and transformer losses. 
Efforts to reduce these losses resulted in the total energy concept, whereby power production was brought into close proximity with the energy user, usually on the same site. (See Figure 1-1b)

Under this concept, much of the waste heat by-product of power generation could be used to produce a heating media, and through one cycle or another, most commonly - absorption, a cooling media could also be produced. No energy conversion is required by the energy user, so those losses are also eliminated.

The Total Energy Concept is valid, however, only during those moments of time when the waste heat by-product of power production (a function of instantaneous power demand) closely coincides with the waste heat neeried to equate to the sum of heat required to meet the simultaneous demands to heating media and cooling media. This ideal situation seldom occurs, so that during periods when waste heat production exceeds demand, the heat must be wasted to atmosphere. When waste heat production is lower than the simultaneous demand, auxiliary boilers or similar fuel consuming equipment must be fired to make up for the deficiency.

The TIES concept differs from the Total Energy Concept in the respect that the electric power output of the local power generation plant goes into the utility company distribution grid, rather than to the user. The user is served power from the grid, as with a conventional system, but also receives heating and cooling media produced from power generation by-product heat from the TIES plant. The effect of this concept is that a very large source-sink for electric energy is provided by the utility company grid. This in turn permits the plant to operate in response to instantaneous thermal demand, rather than instantaneous power demand. No auxiliary firing is ever required. No waste of unneeded byproduct energy to atmosphere ever occurs. Balance is achieved by either delivering excess power into the grid or by withdrawing power production deficiency from the grid. Near optimum efficiency is achieved during all operating conditions. There is no need whatsoever for the power generating plant to be sized to meet the power demand, since it seldom, if ever, tracks the power demand. Sizing of the electric generation is solely a function of economics and the demand for waste heat.

To proceed with the TIES concept, several conditions must be met:

1. Because TIES delivers its electric power output to a serving utility company grid, it becomes a part of the total utility company system and should, therefore, be directly operated by the utility company. The utility company need not own the plant, however.

2. To avoid instability in the combined systems, the TIES plant should be small compared to the utility company. In point of fact, the TIES maximum capacity should not exceed about 20 percent of the utility company's minimum demand. 


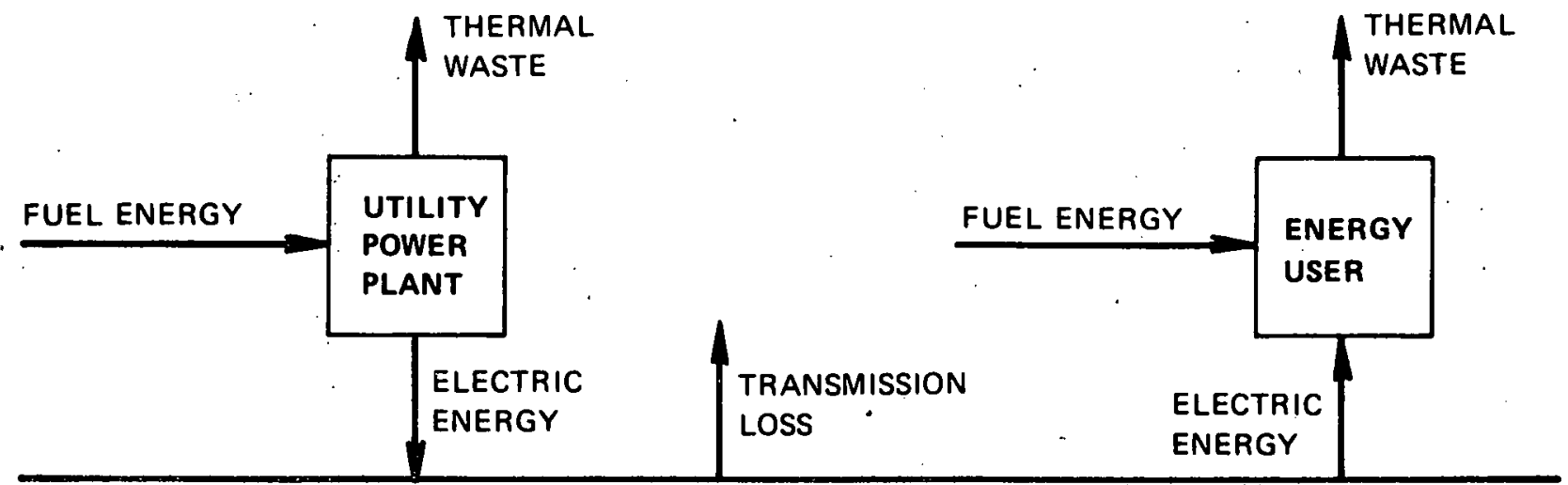

Utility Company Power Distribution Grid

1a - CONVENTIONAL ENERGY CONCEPT

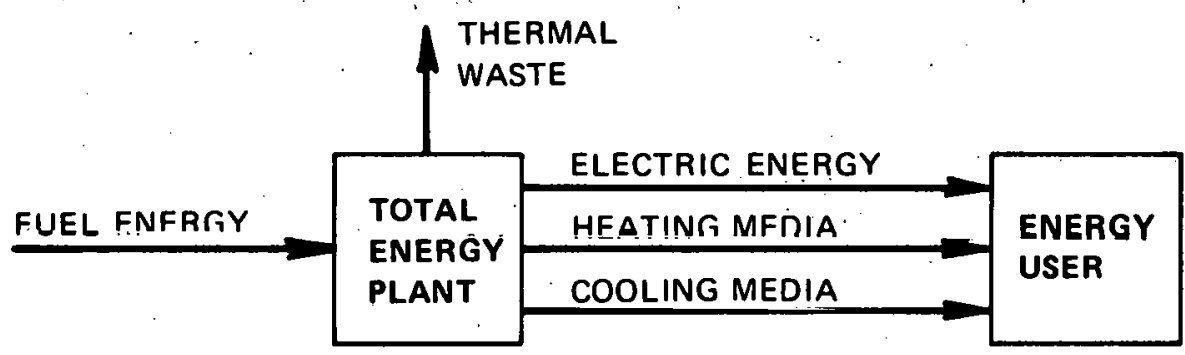

$1 b$ - TOTAL ENERGY CONCEPT

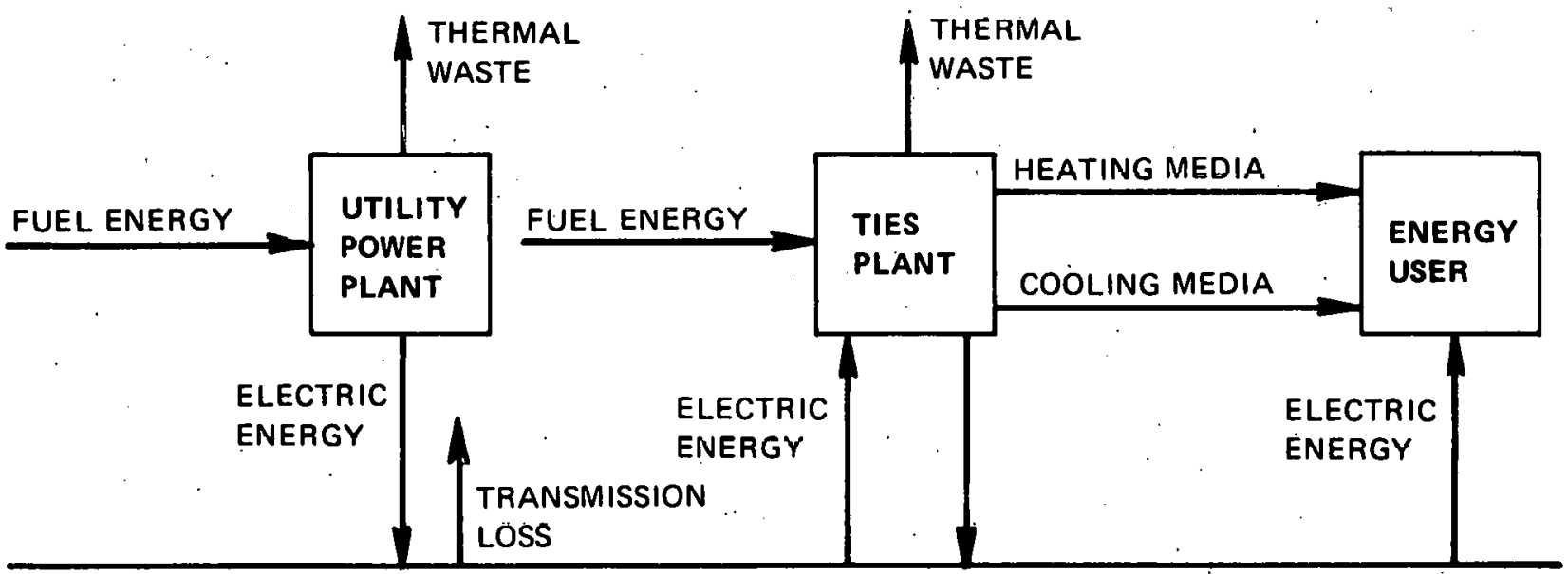

Utility Company Power Distribution Grid

1C - TIES CONCEPT 
3. Because the TIES maximum output is available to the utility on demand to meet emergency or other operating situations (albeit at lower energy efficiencyl the utility company should see fit to pay a monthly demand charge to the TIES plant owner for this available demand. The amount of this demand charge would normally be negotiated in the range of cost that the utility company would invest in some other form of peaking plant.

4. The TIES energy output, measured in KWH delievered to the grid should be purchased by the utility company. The negotiation of rate would be based on the cost of equivalent options available to the utility company for purchased power. It should be noted that thermal storage (discussed later) coupled with various heating-cooling equipment size selections can be tailored so that power is produced only during the utility company's period of peak demand. when the value of purchased energy is consider ably greater than excess energy produced during periods of off-peak demand.

The Pasadena Department of Water and Power (DWP), a municipally owned utility company, agreed to enter into such an arrangement with the Pasadena Redevelopment Agency (PRA) whereby DWP would operate such a plant and pay a monthly demand charge to PRA in the amount of $\$ 1.00$ per $\mathrm{KW}$ of installed capacity and purchase electric energy delivered to the grid at the rate of 1.8 cents per KWH.

PRA would construct the plant and receive all revenue from the sale of heating and cooling media to the adjacent energy using community.

Together, the two agencies sought and received funding from the Energy Research and Development Administration (ERDA) to explore the viability of the approach.

In arguing for these funds from ERDA the agencies relied on the apperent ad. vantages of TIES which are obvious:

- Continuous operation at optimum efficiency would consume less fuel.

- Less fuel burned would produce less air pollution.

- Demand capacity installed in TIES plants would offset part of the capital requircment neerled to expand available demand by the utility company.

This report indicates the merits of rigorous analysis, for all that is apparent is not necessarily true. 


\section{c. DEFINITION OF SITE AND BUILDING DESIGN DATA}

\section{The Energy Using Community}

The community under study is a proposed Retail/Office Building development in downtown Pasadena, California. The development consists of a two level retail shopping center, adjoining office buildings and parking facilities, the composition of which is planned as follows:

\section{DESCRIPTION}

Retail Center:

Major Department Stores

Tenant Retail Shops courts, corridors, stairs and exits)

\section{APPROXIMATE AREA}

(SQUARE.FEET)
Common Areas (Enclosed malls,

295,000

317,000

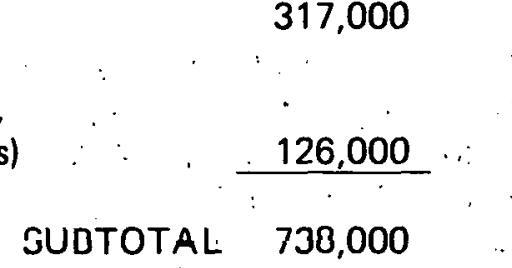

Office Buildings (Two in number)

60,000

TOTAL

798,000

Parking Facilities:

Two underground parking levels located under the shopping center proper 829,000

Adjoining multi-level parking 628,000

TOTAL $\quad 1,457,000$

Drawings of the proposed Energy Using Community are shown in Figures 1-2 through 1.4 inclusive.

In addition to the Energy Using Community described above, the program was to consider the future development of nearby office and retail.spaces that would total an additional 642,000 square feet. 


\section{Weather Data}

I he weather conditions prevailing at the development site are those of the typically benign climate of Southern California. Summers are warm and dry with somewhat cool evenings. Winters are mild, with freezing temperatures rarely achieved. Temperatures lower than 50 degrees $F$ during normal business hours are similarly rare. Seasonal variations are minor. Very warm weather can occur during the "winter" season and it is not uncommon to have a greater demand for cooling occurring during this period than during the spring or fall months.

- The hourly weather data for a typical year was obtained from the nearest local National Weather Bureau station in Burbank, California. Outside air (OSA) Dry Bulb temperatures in degrees Fahrenheit are shown in Figures 1-5, 1.6 and I-7 plotted on an hourly basis for three weeks representing the coldest week (January), the hottest week (August) and a typically mild week (November).

Cooling and heating design conditions recommended by ASHRAE for Pasadena are as follows:

\section{Cooling (.5\% values)}

Outside dry bulb $=94^{\circ} \mathrm{F}$

Outside wet bulb $=70^{\circ} \mathrm{F}$

Daily Range $=28^{\circ} \mathrm{F}$

Heating (.6\% values)

Outside dry bulb $=39^{\circ} \mathrm{F}$

\section{Building Design and Usage}

As is typical with projects in the early stage of development, the details of neither design nor usage havo bocn totally defined. There diul exist from the developer, however, certain information upon which reasonable cngineering judgments cuuld be ludsed:

a. There would be two large stores:

- A two-level store, similar in character to a major J. C. Penney sture.

- A three-level store, similar in character to a.Broadway Department Store (Broadway being a major Southern California chain). 
b. There would be a typical mix of tenants in the balance of retail area, as tabulated in APPENDIX B, with desired percentage of area allocation to:

- Food stores

- Drug stores

- Junior department stores

- Restaurants

- Real estate-travel agencies and other office type functions

- Jewelry, men's and women's shoes and similar specialty types of stores

c. Parking garages would be ventilated to meet minimum code requirements and would have mechanical ventilation only for spaces below ground.

d. It was assumed that the design of the building envelope, lighting and air conditioning systems would meet the minimum requirements of the pending State of California Energy Conservation Standards for New Non-Residential Buildings (Title 24) which is similar in nature to ASHRAE Standard 90-75. The construction details and factors used are tabulated in Appendix A.

e. Usage was given as follows:

- Weekdays - 10:00 AM to 9:00 PM

- Saturday - 10:00 AM to 6:00 PM

- Sundays and Holidays - Closed

- $\quad$ Christmas Period (December 1 through 24)

$$
\begin{aligned}
& \text { Weekdays - 10:00 AM to 10:00 PM } \\
& \text { Saturday 10:00 } \mathrm{AM} \text { to } 10: 00 \mathrm{PM} \\
& \text { Sunday - 11:00 AM to 7:00 PM }
\end{aligned}
$$

- $10-20 \%$ interior lights on during closed periods for security and display purposes

- Outside decorative lighting from 7 to 10 PM daily

- Covered parking lighting from 7 AM to 10 PM 


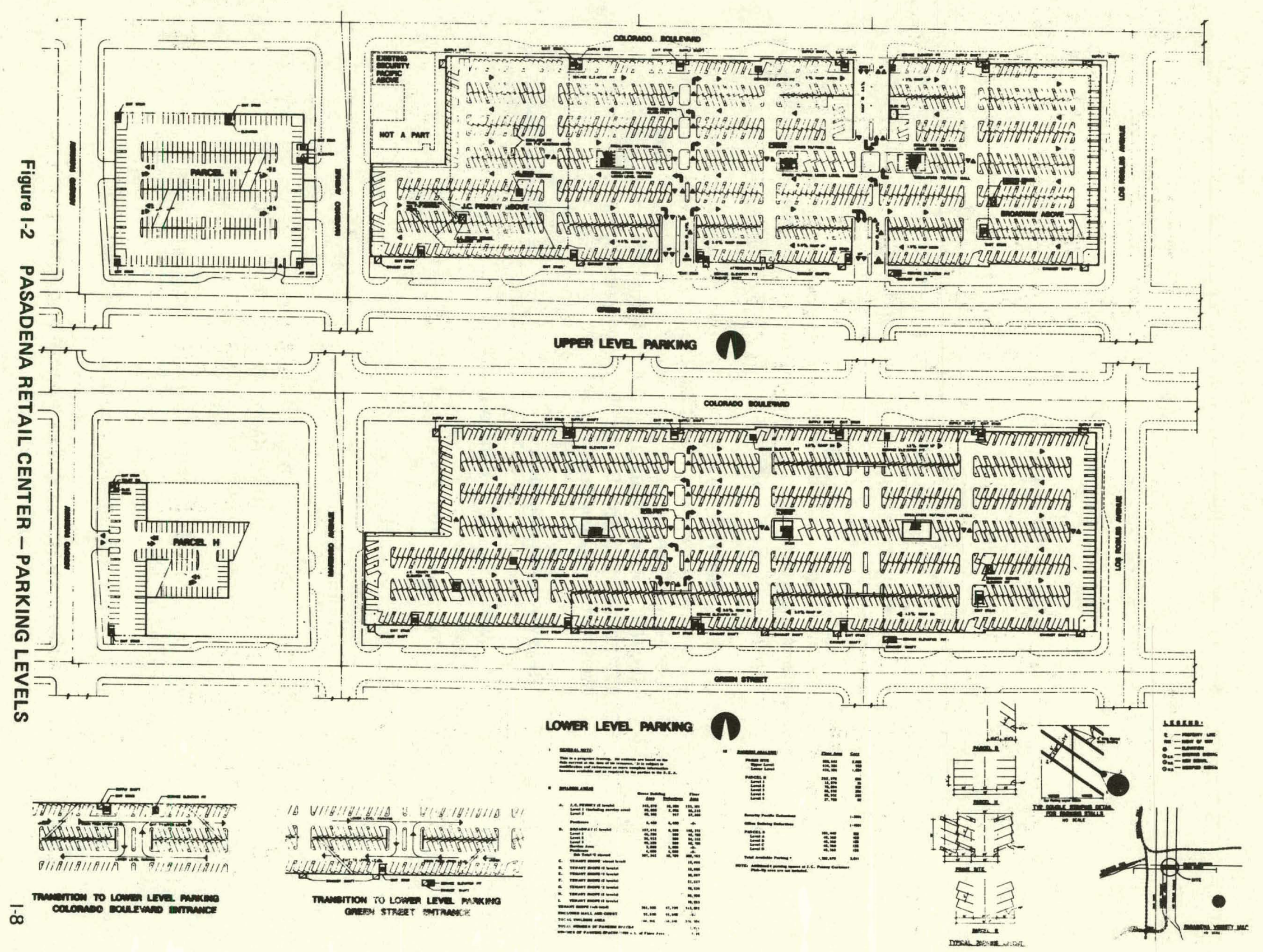




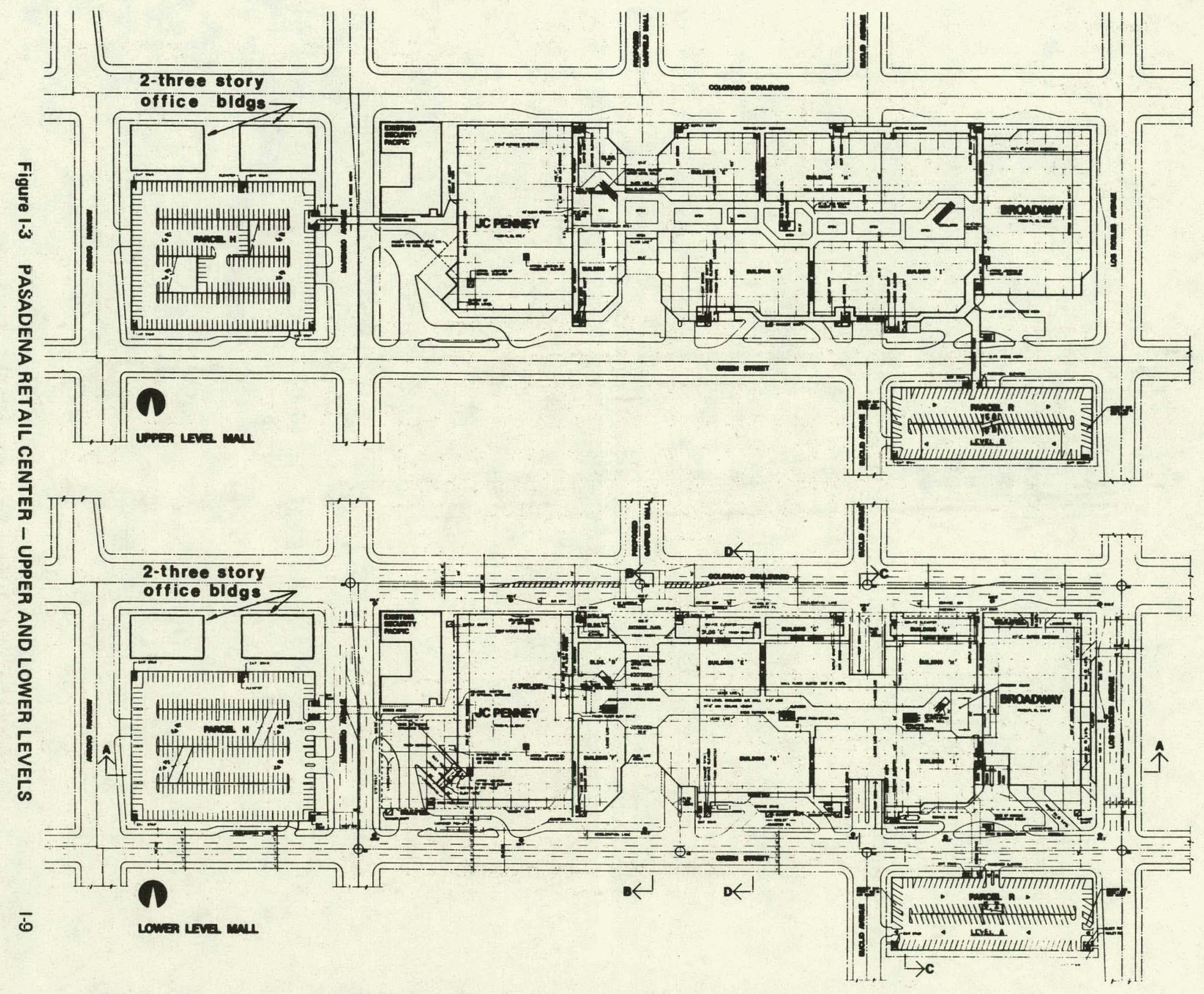




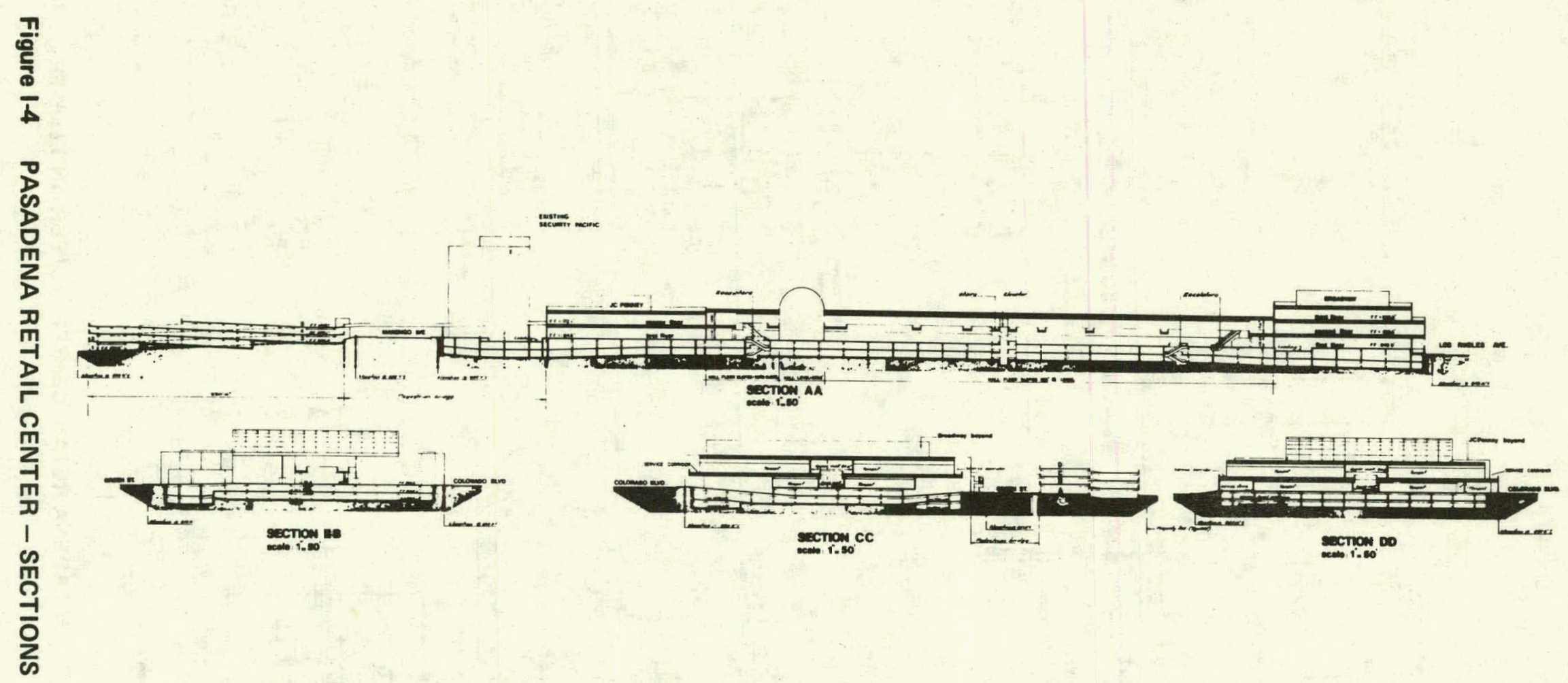

ذ̇ 


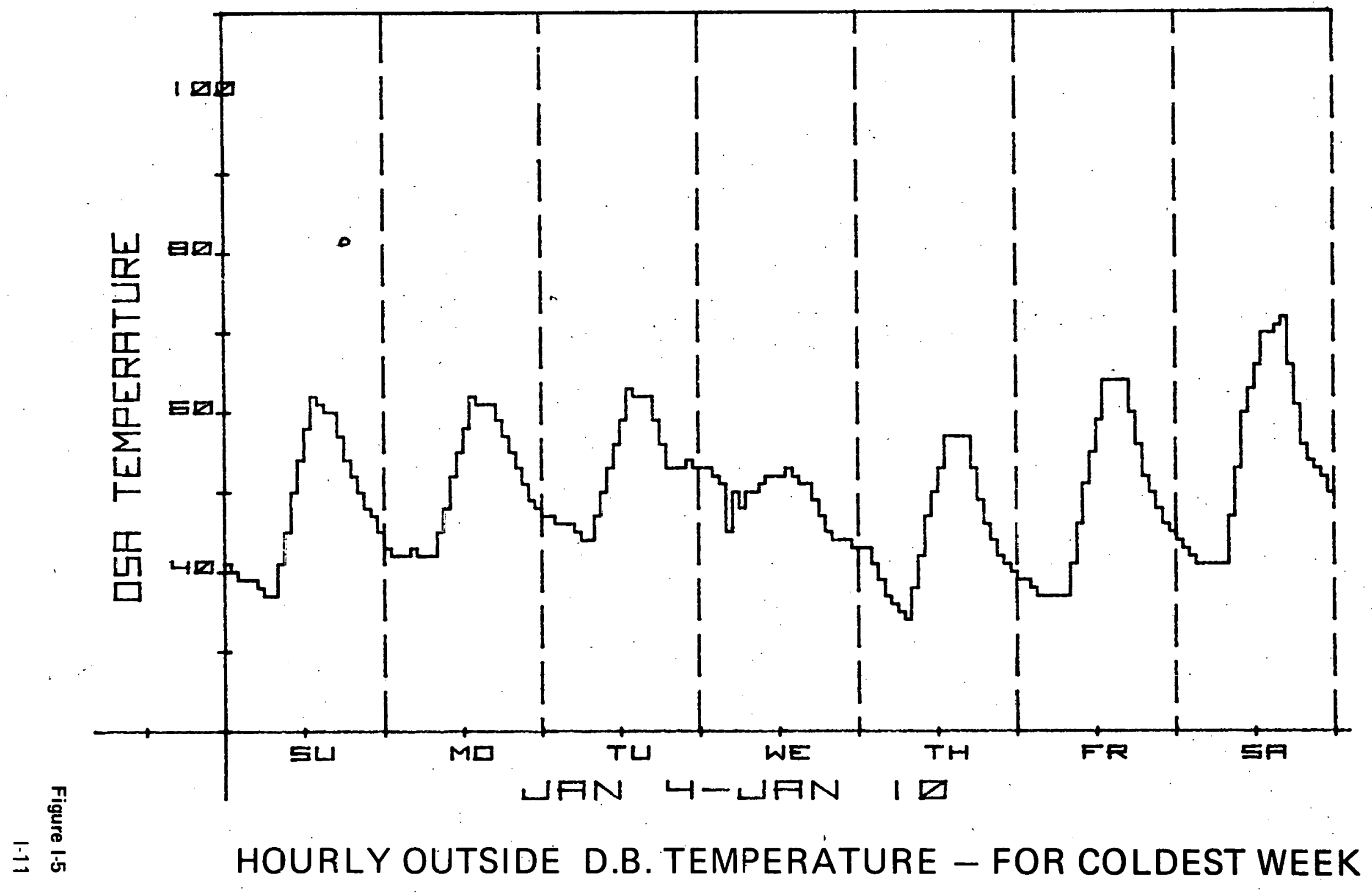




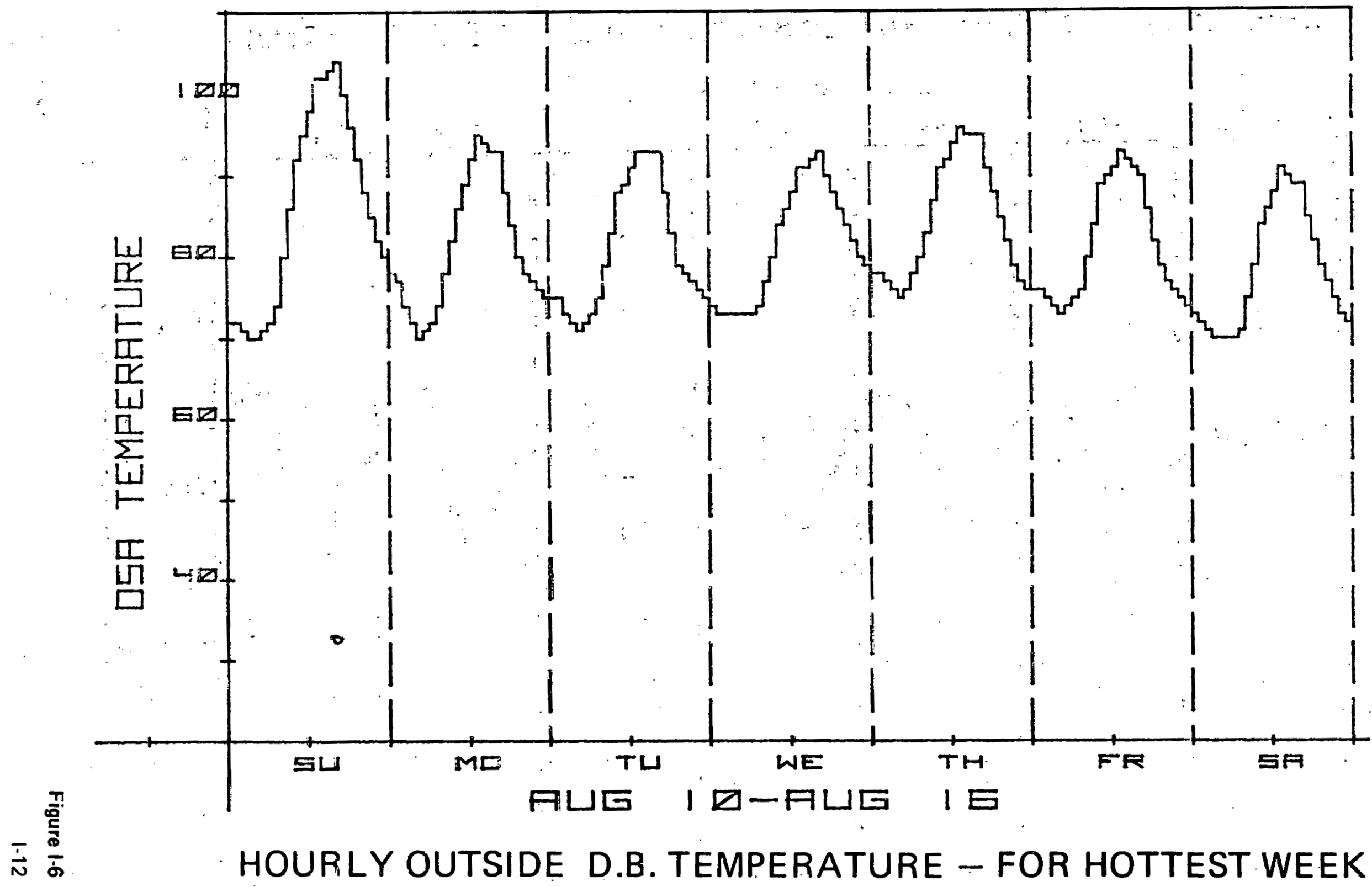




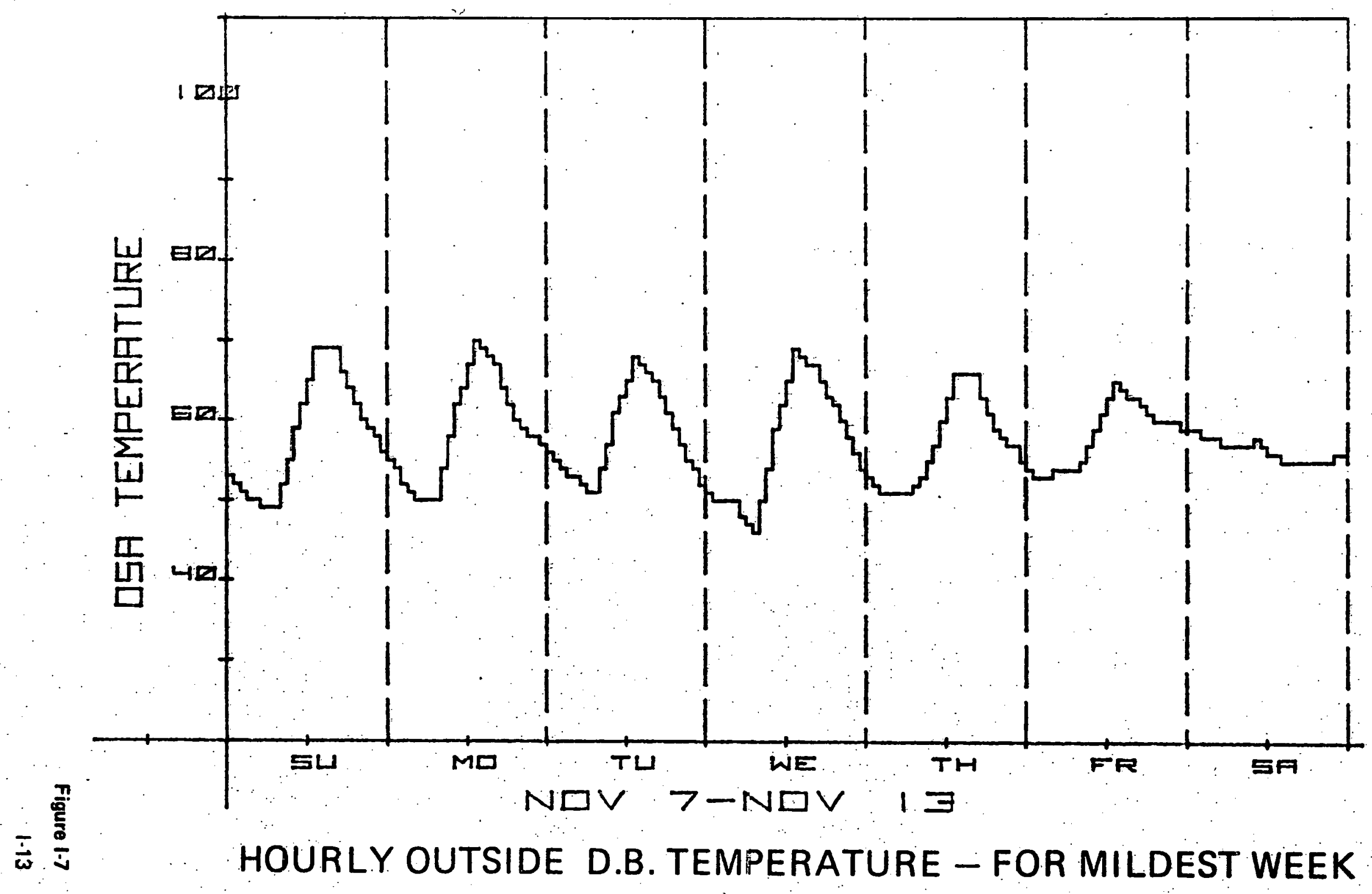




\section{DEFINITION OF LOADS}

\section{A. COOLING, HEATING AND NON-HVAC LOADS}

\section{Required Services and Utilities}

The Energy Using Community described and defined in Section I requires the following energy services:

a. Cooling Media

- For space cooling

b. Heating Media

- For space heating

- For domestic hot water

c. Electric Power

- For lighting of interior spaces, garages and landscape areas

- For miscellaneous electrical loads

- For cooking equipment in restaurant areas

- For vertical transportation systems and materials handling systems

- For pumps and fans

\section{Analysis of Space Cooling and Heating Loads}

The maximum cooling and heating loads, for the Energy Using Community, were determined using S\&H Information Systems, Inc. H-Load computer analysis program.

The data and procedure used were as follows:

a. Design conditions and building construction characteristics were based on data described in Section IC. These building construction characteristics, heating and cooling design criteria and building lighting levels were based upon the pending Energy Conservation Standards for New Nonresidential Buildings, State of California Administrative Code, Title 24. 
b. The building was subdivided into tenant areas and types of usage, such as department stores, shoe stores, restaurants, sales and stock areas, etc., based on information received from the proposed developer of the project. Individual tenant area loads for lighting, miscellaneous power, specialized power, and occupants were determined from developerfurnished records of similar projects and from prior experience of the engineering team. These loads are tabulated in Appendix B.

c. An assumption was made of the type of heating and ventilating system which would be used in the various areas of the development. Air handling systems were assumed to be of the variable volume type and were input as such. These systems are included under the definition of the Conventional System in Appendix. F.

d. All of this data was input into the H-Load computer analysis program. The program calculated required supply air quantities and maximum cooling and heating loads for each area (room) and each zone. The program summed up all of the calculated data for each zone to calculate the total instantaneous cooling and heating loads.

The total building heating load, on this basis, was $11,619,000$ BTU/HR, which, although the instantaneous building load would be lower than this sum of individual zone loads, gives an indication of the magnitude of the full building heating load.

The maximum building cooling load was calculated to be 3,006 tons. This data is shown on the $\mathrm{H}$.Load computer proyram printout sheets entitled "Full Building Results" and "Building Refrigeration Tonnage Profile," Tables II-1a, II-1b, and II-2 which follow.

\section{Energy Analysis Computer Program}

The community eritergy usage was analyzed using the Electrical Energy Association's AXCESS computer analysis program (Alternate Choice Comparison for Energy System Selection). The program analyzed the consumption and use of energy for the Energy Using Community, including all of the building areas previously defined and the ancillary landsraping areas and parkıng structures. 


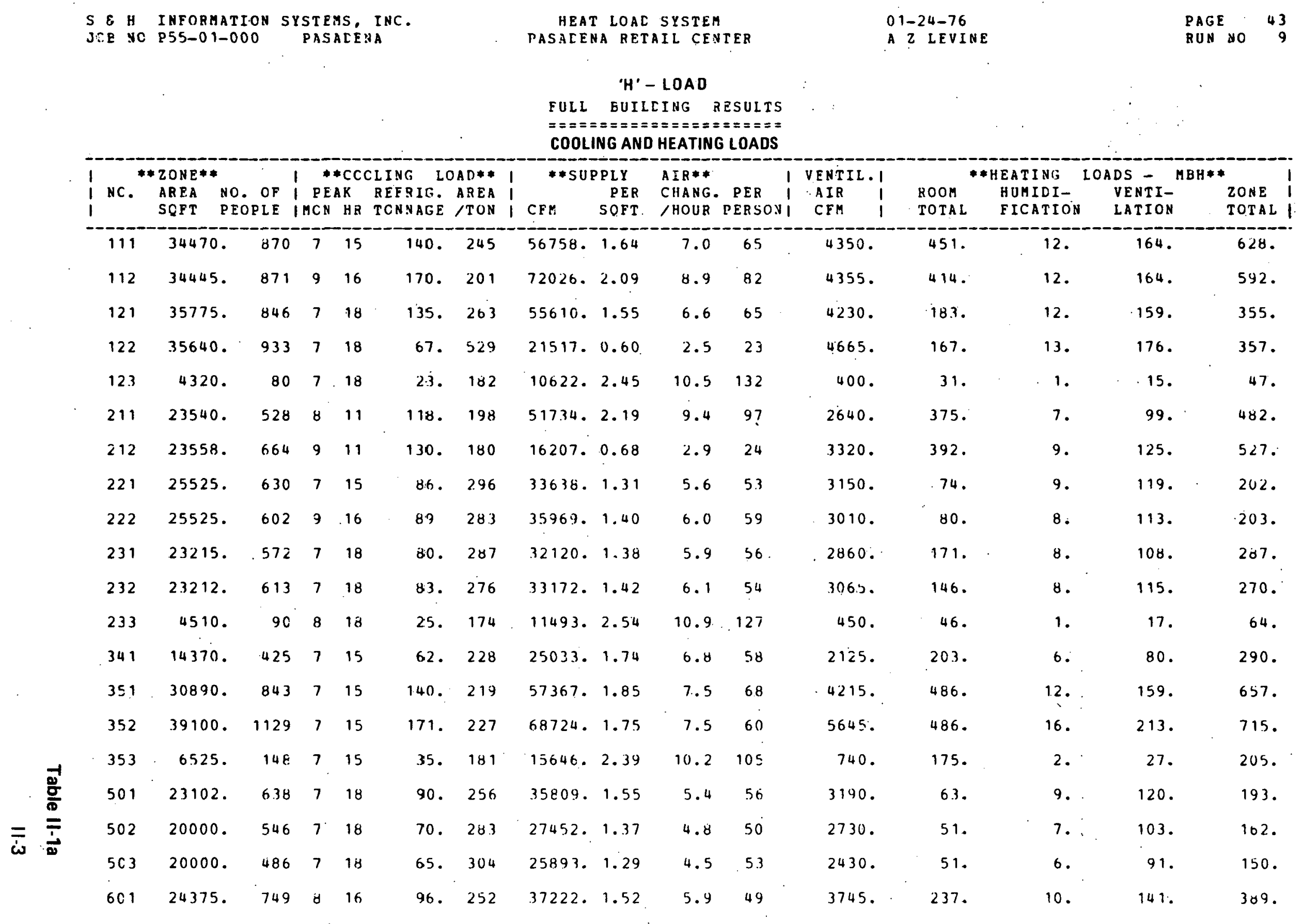


$S E H$ INFORMATION SYSTEMS, INC. JCB NO P55-01-000
HEAT LOAL SYSTEM PASAEENA RETAIL CENIER
$01-24-76$

A $Z$ LEVINE
PAGE RUN NO 9

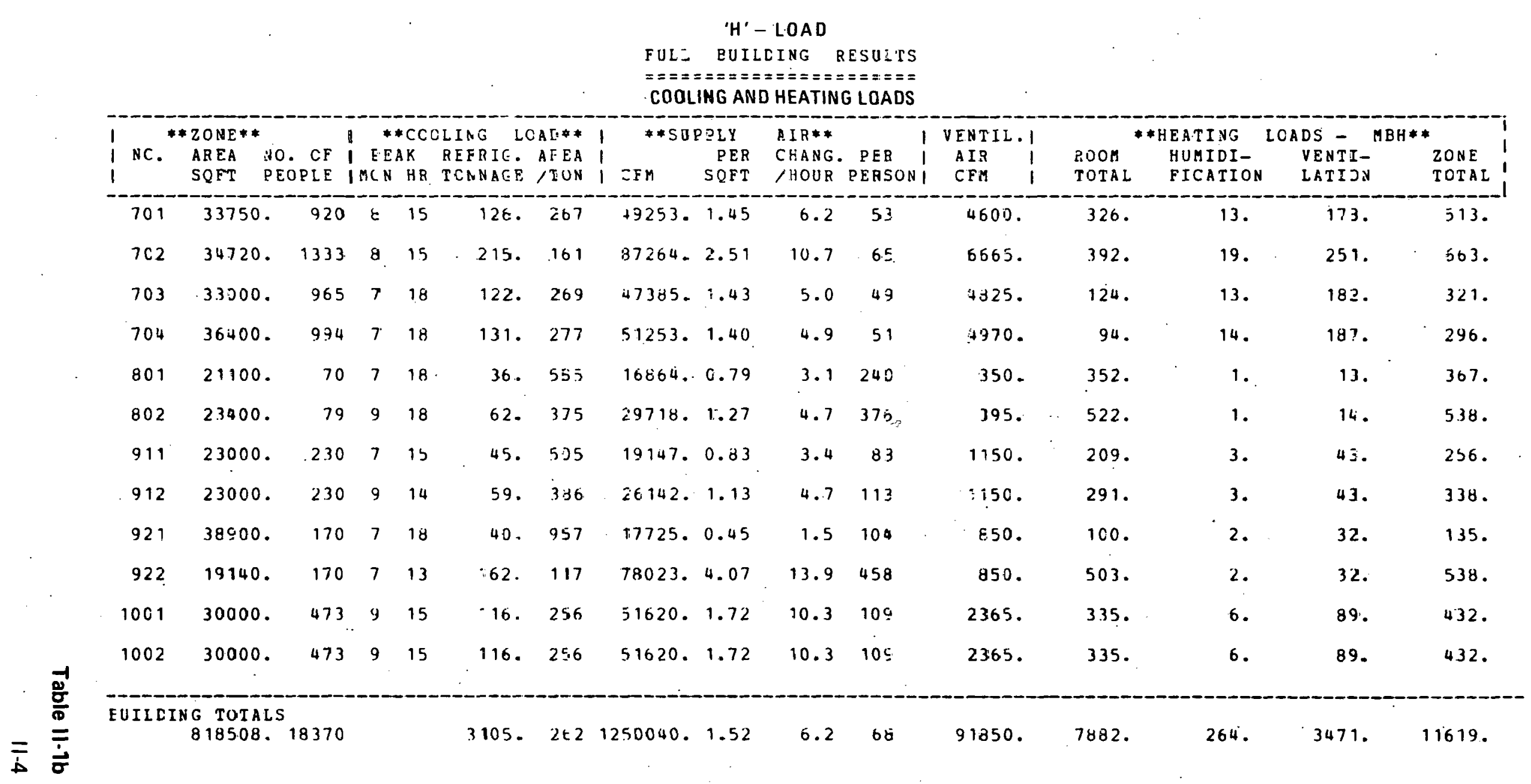


H IXPORHATION SYSTEMS, INC. $J C E$ УC P55-0.1-000
HEAT LOAD SYSTEM

PASACEHA RETAIL CENTE 'H' - LOAD

BUILDING REFRIGERATION TONHAGE EROFILE

COOLING LOAD--

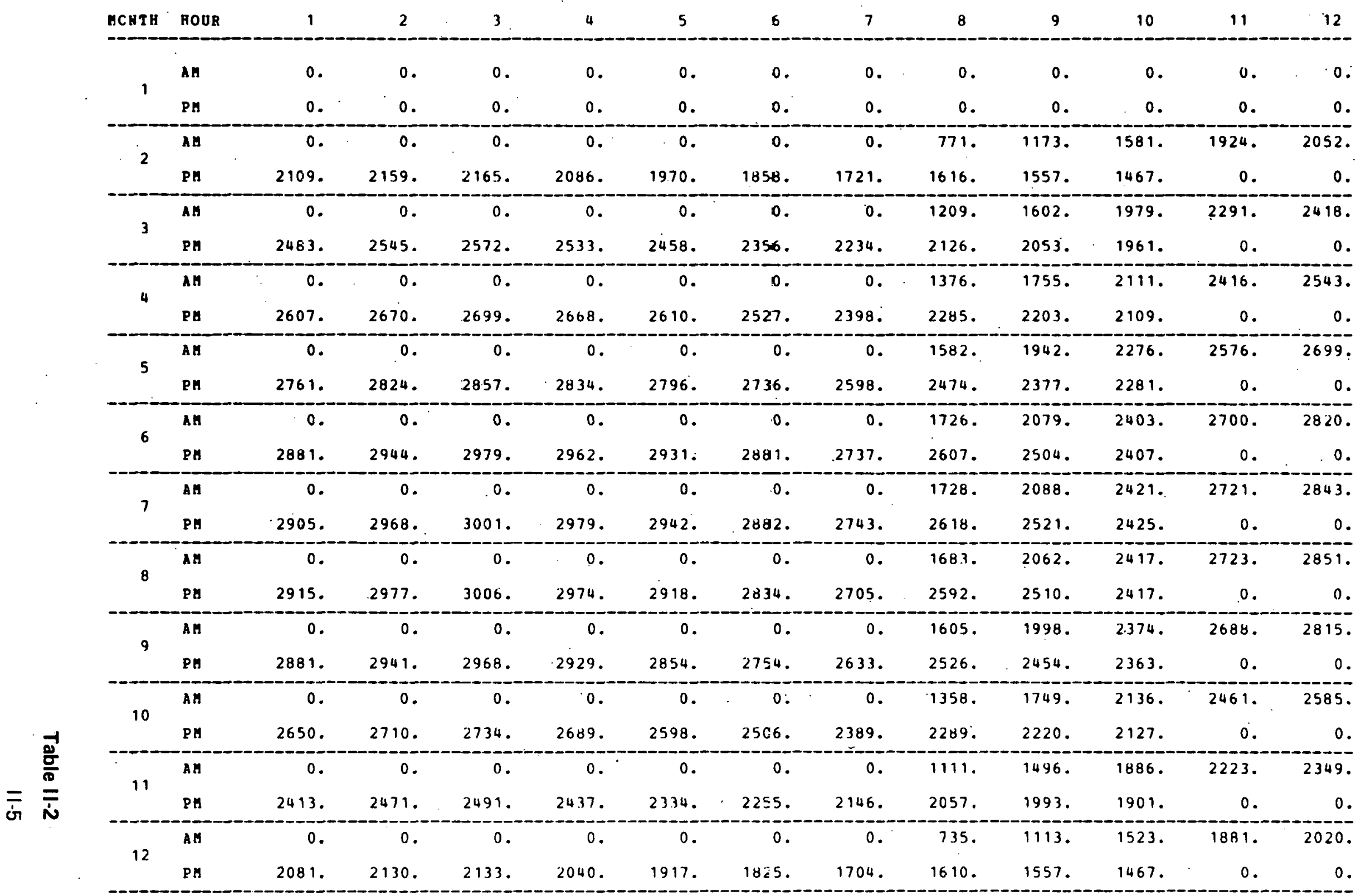


The data and procedure used were as follows:

a. In Section IIA, a determination of the services required by the community was made. The assignment of these services to a utility for the energy, usage analysis is as follows:

Space Cooling

COOLING UTILITY

Space Heating

Domestic Hot Water

HEATING UTILITY

Lighting

Misc. Power (convenience receptacles for

portable appliances, etc.)

Vertical Transportation

Materials Handling

ELECTRICAL UTILITY

Fans \& Pumps for HVAC \& Plumbing

Systems

Cooking

b. Heating and cooling design criteria, building electrical lighting and power levels and building construction characteristics were based on the same data used for the $\mathrm{H}$-Load Analysis, and as tabulated in Appendices A, B and $D$ and for the weather year of 1975 recorded at Burbank, California, a nearby station with weather similar to Pasadena.

c. The calculations for domestic hot water heating loads were made based on storage-type hot water heaters. Hot water flow rates for the retail areas wcrc bascd on gallons per day per persuri. Thie figures used were taken from a study of comparable spaces made by the Department of Civil Engineering of the University of Maryland, publisher in the AWWA Journal, May 1975.

Office area and restaurant loads were calculated on the basis of the latest publisshèd data by the American Society of Plumbing Engineers.

A tabulation of the estimated domestic hot water loads and usage profiles is included in Appondix $C$.

d. Profiles were established for electrical power on an hourly basis for each of the various building areas within the community, and for all the services required to those areas.

- The proflles were based on the hours of operation stated in Section I.

- . The profiles used were obtained from the Electric Energy Association and modified from analysis of computer printouts of hourly electrical meter readings of similar local department stores obtained from the Southern California Edison Co. 
- All cooking and water heating was assigned to the electrical service for the Conventional System, and cooking was assumed to be done electrically for the Central Cooling/Heating Plant System. The profiles used in this analysis and the electrical loads and profile maximum percentages used are tabulated in Appendix $D$.

- $\quad$ Part-load efficiency curves were developed for all primary cooling and heating equipment, based upon data obtained from equipment manufacturers.

e. The AXCESS computerized energy analysis program, using the abovementioned input data, calculated and tabulated instantaneous zone cooling and heating loads, and from these, calculated the required rates of conditioned air circulation and the power requirements and energy consumed by the required air moving equipment (fans).

The AXCESS program then calculated and tabulated the hourly, monthly and yearly values of the electrical energy usage of the building, and the energy used for building space cooling and heating and domestic water heating. It also calculated and tabulated the maximum demand values and time of occurrence for these !oads.

These values and quantities were shown in the AXCESS program printouts in the form of simulated "meter" readings. The program printout for the yearly total energy consumption for the building is shown in Appendix $E$.

\section{B. BUILDING PEAK LOADS AND ANNUAL ENERGY CONSUMPTION}

1. The results of the AXCESS energy analysis (computer run of March 4, 1976) shown in Appendix $E$, is summarized as follows:

a: Building Base Power: 22,575,248 KWH with maximum demand of 5,803 KW occurring on December 7 at 3:00 PM.

b. Building Cooling: $3,447,875$ ton-hours with maximum demand of 2,952 tons occurring on August 13 at 10:00 AM.

c. Building Heating: 7,566 million BTU with maximum demand of 10 million BTU occurring on January 2 at 10:00 AM.

d. Building Domestic Hot Water: 2,184 million BTU with maximum demand of $800 \mathrm{MBTU}$ occurring uniformly at 2:00 PM on each business day.

2. Plots were made of the hourly building electrical power flow (demand), cooling flow, and heating flow, for the coldest week (January), hottest week (August), and most stable week (November), based upon the load data and AXCESS computer program runs of March 4 and May, 1976. 
Figures $11-1$ through $11-9$ inclusive, following, illustrate the daily flow and fluctuation of energy usage and occurence of peak loads.

3. It is important to understand the relative energy use of the facility. Expressing annual usage in equivalent terms of trillions of BTU:

265.5 are consumed to produce electric power

86.2 would be consumed to produce cooling with an absorption cycle

32.4 would be consumed to produce cooling with a compressive cycle

\section{6 is consumed for heat}

\section{2 is consumed for domestic hot water}

The user's energy needs were dominated by electric power and by cooling, both of which involve second-law cycles, and are poor candidates for use of low potential waste heat. 'The sum of first-law energy needed for space heating and water heating which are excellent users of waste, represented only 2 to 3 percent of the total energy consumed. 


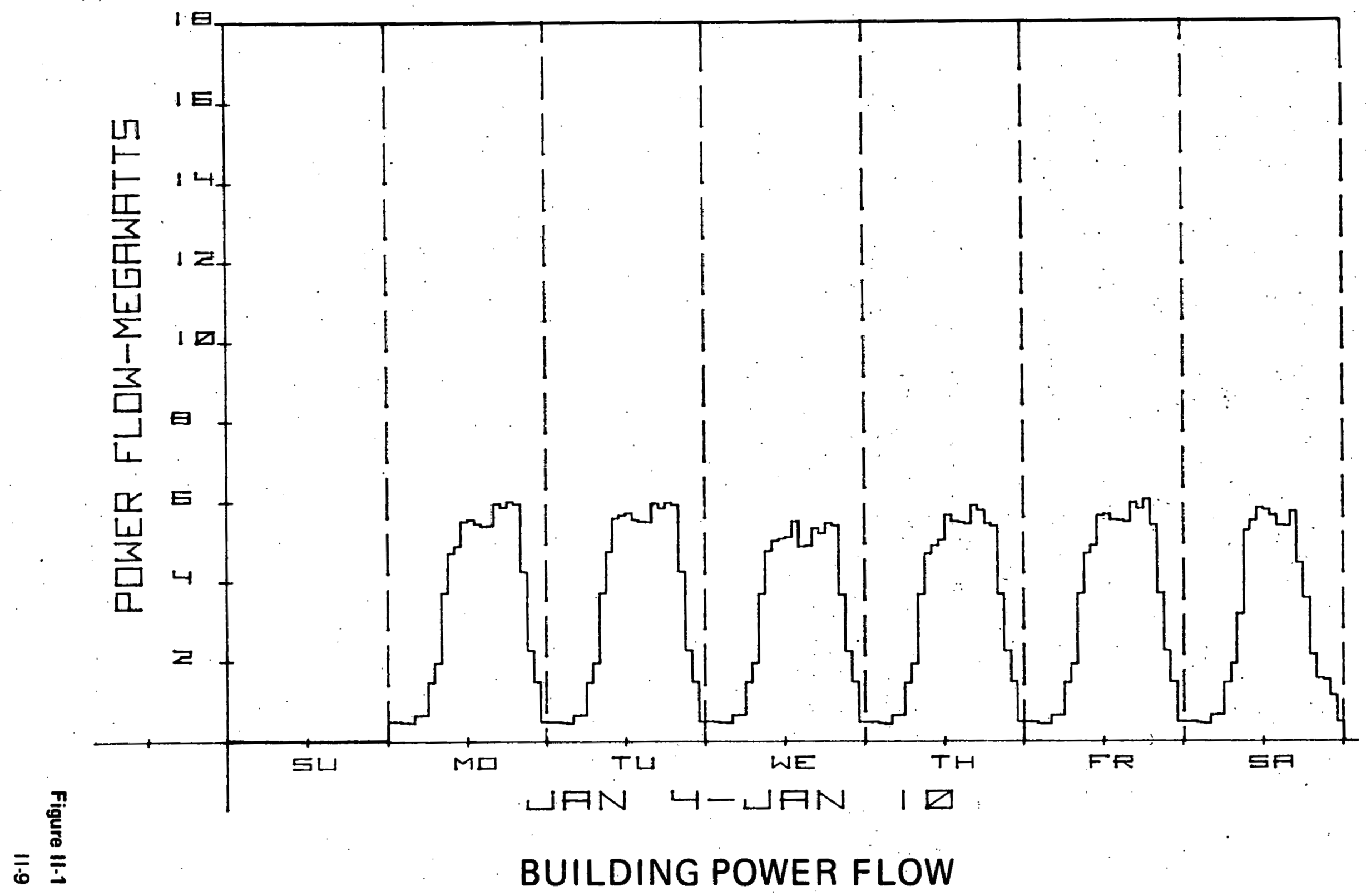




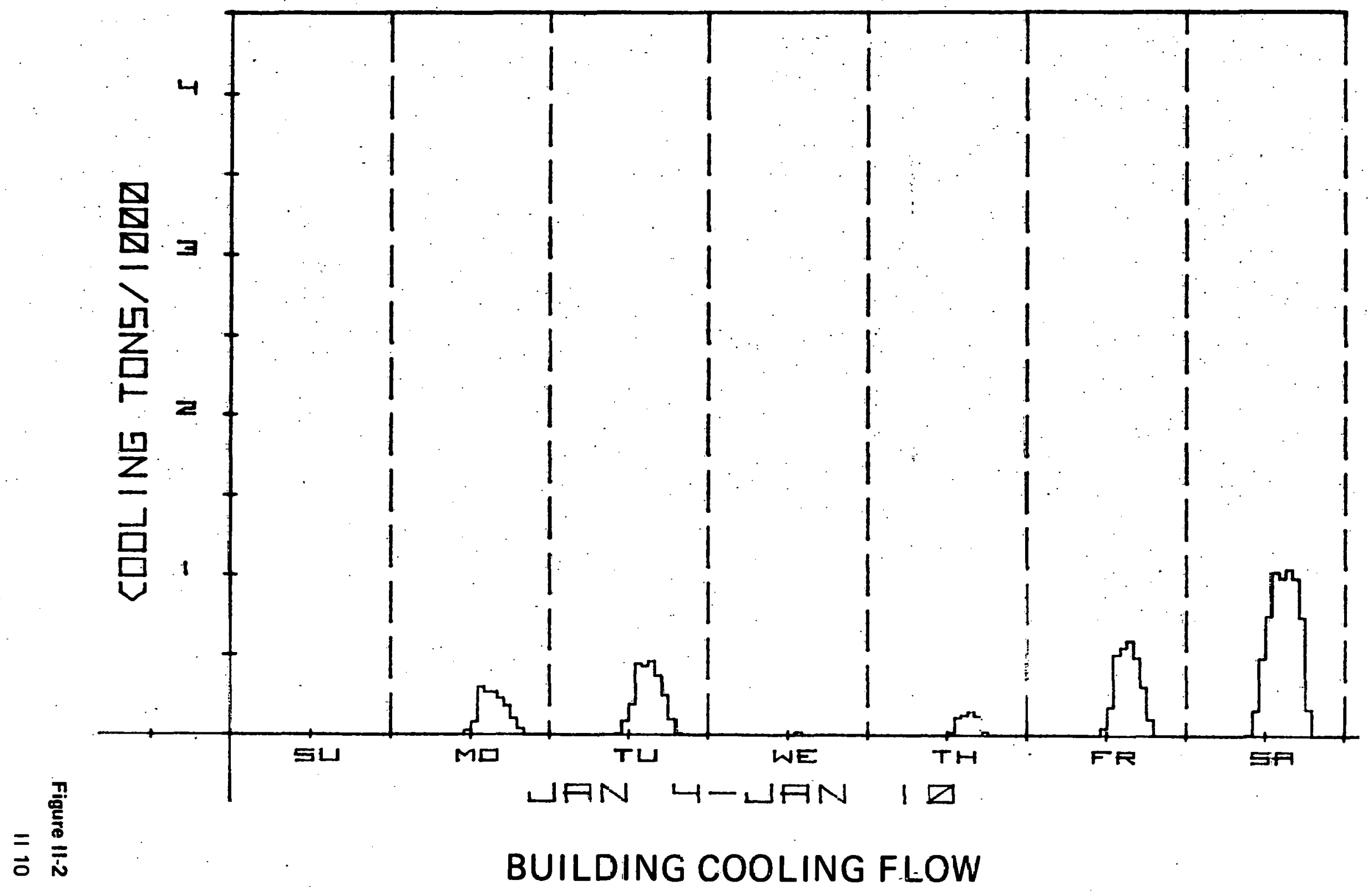




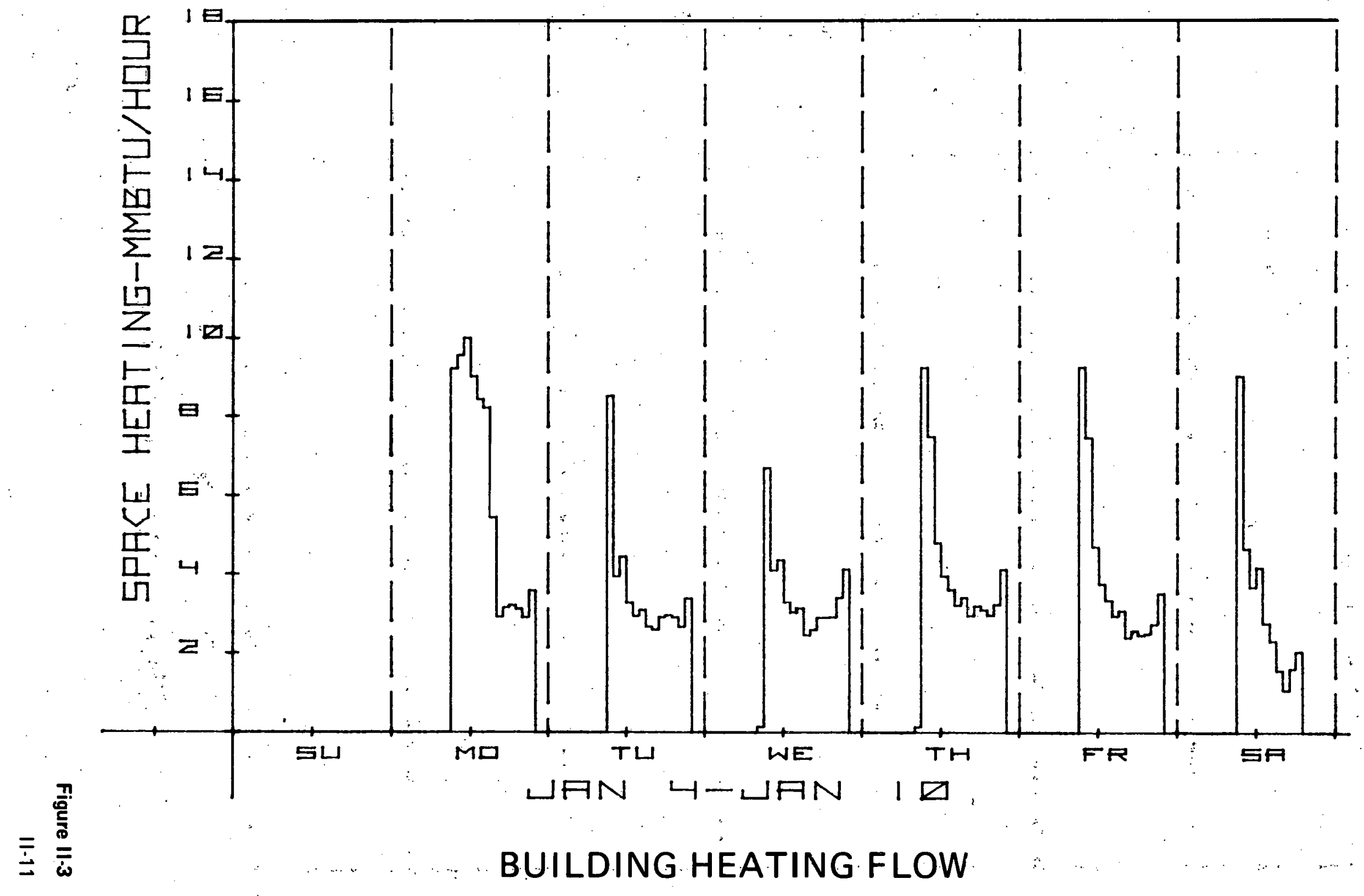




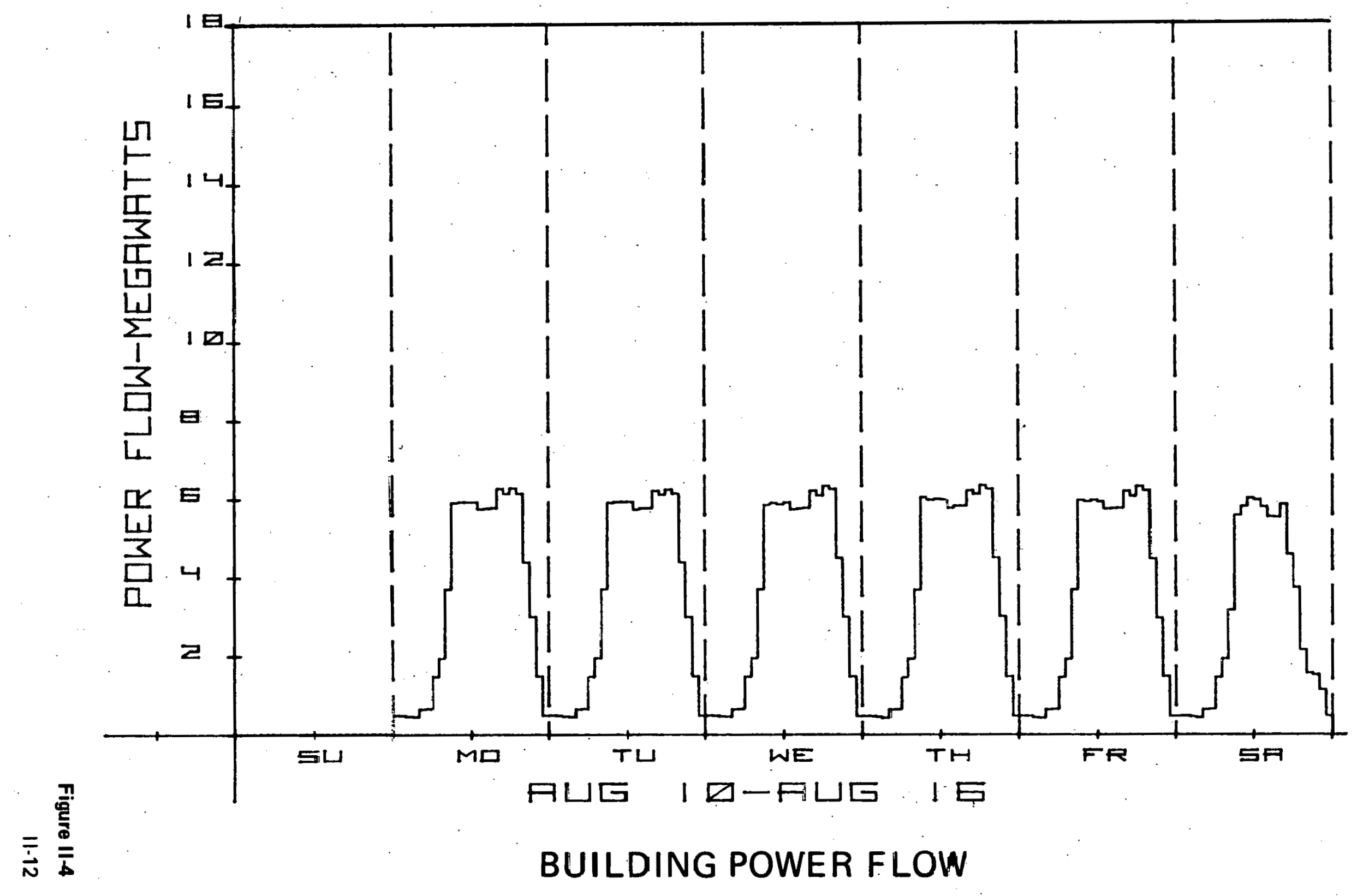




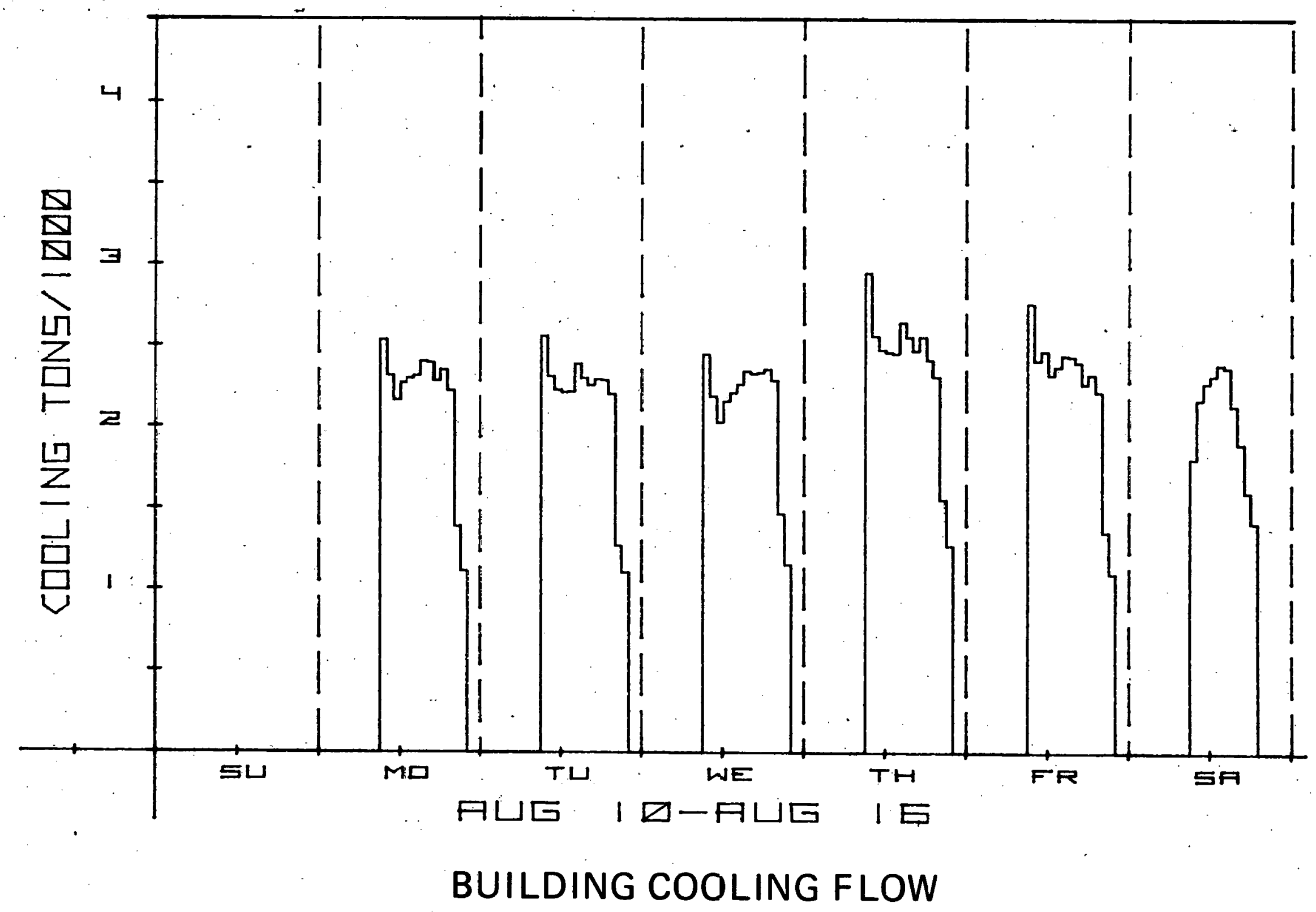




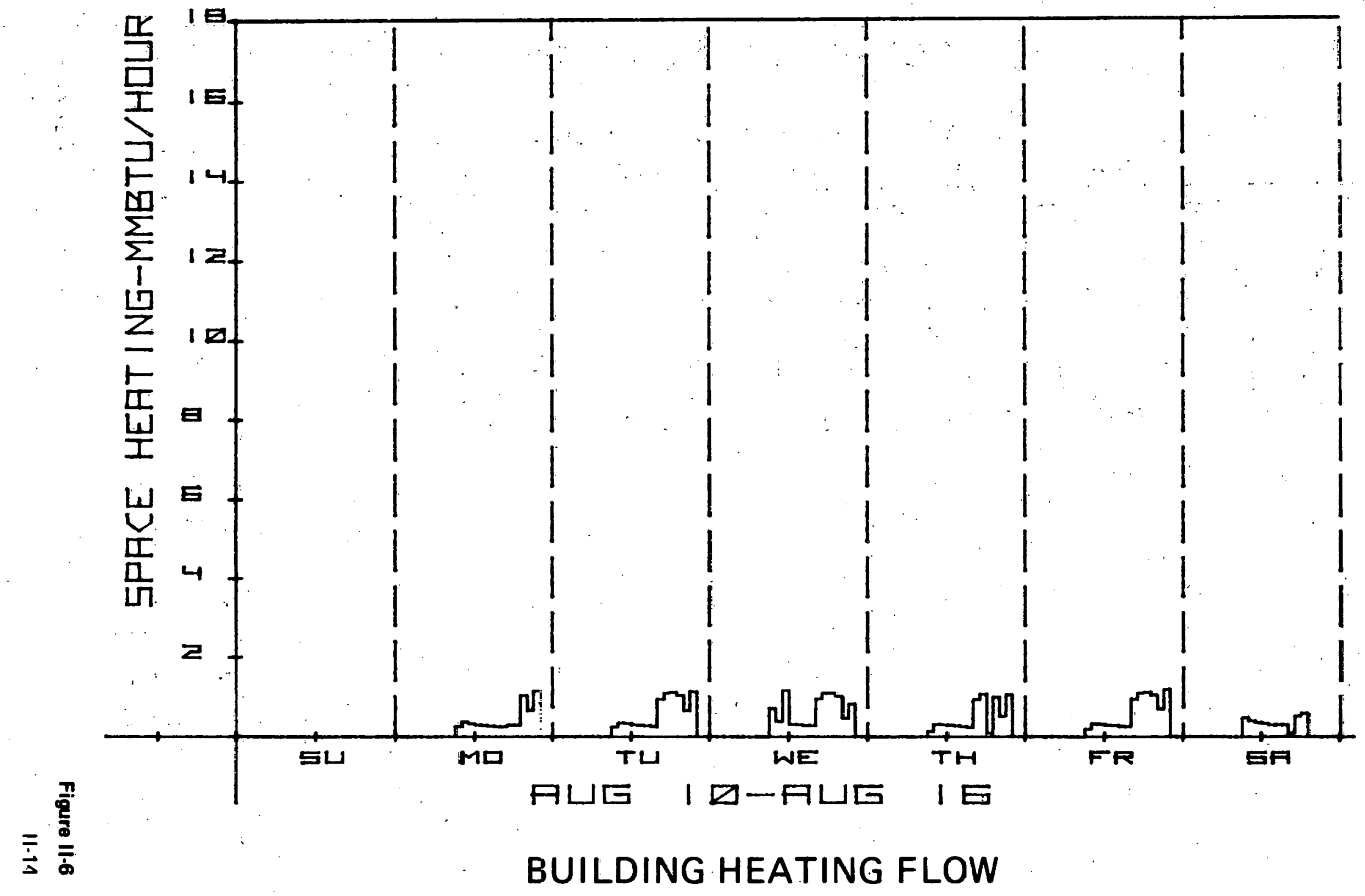




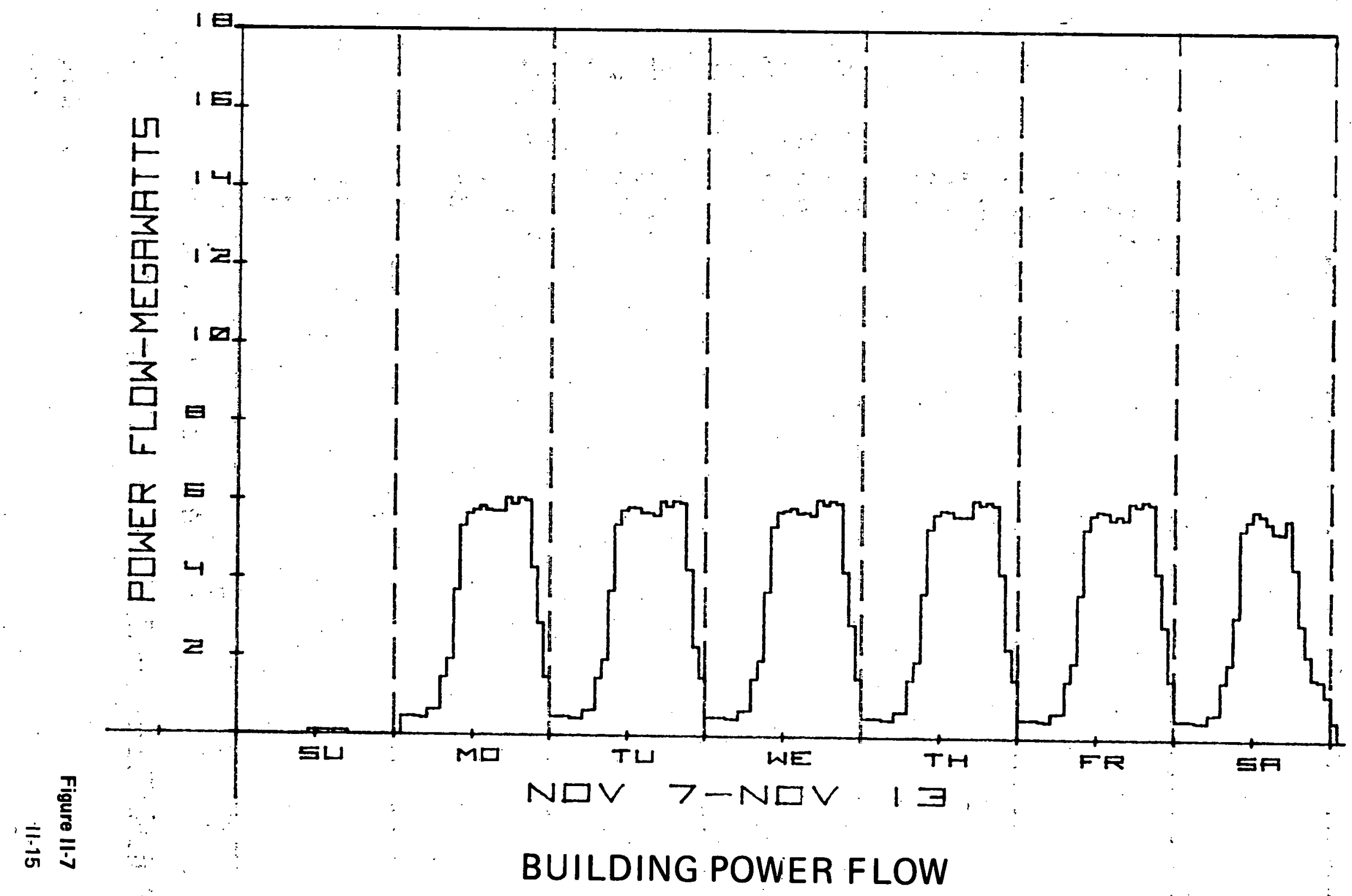




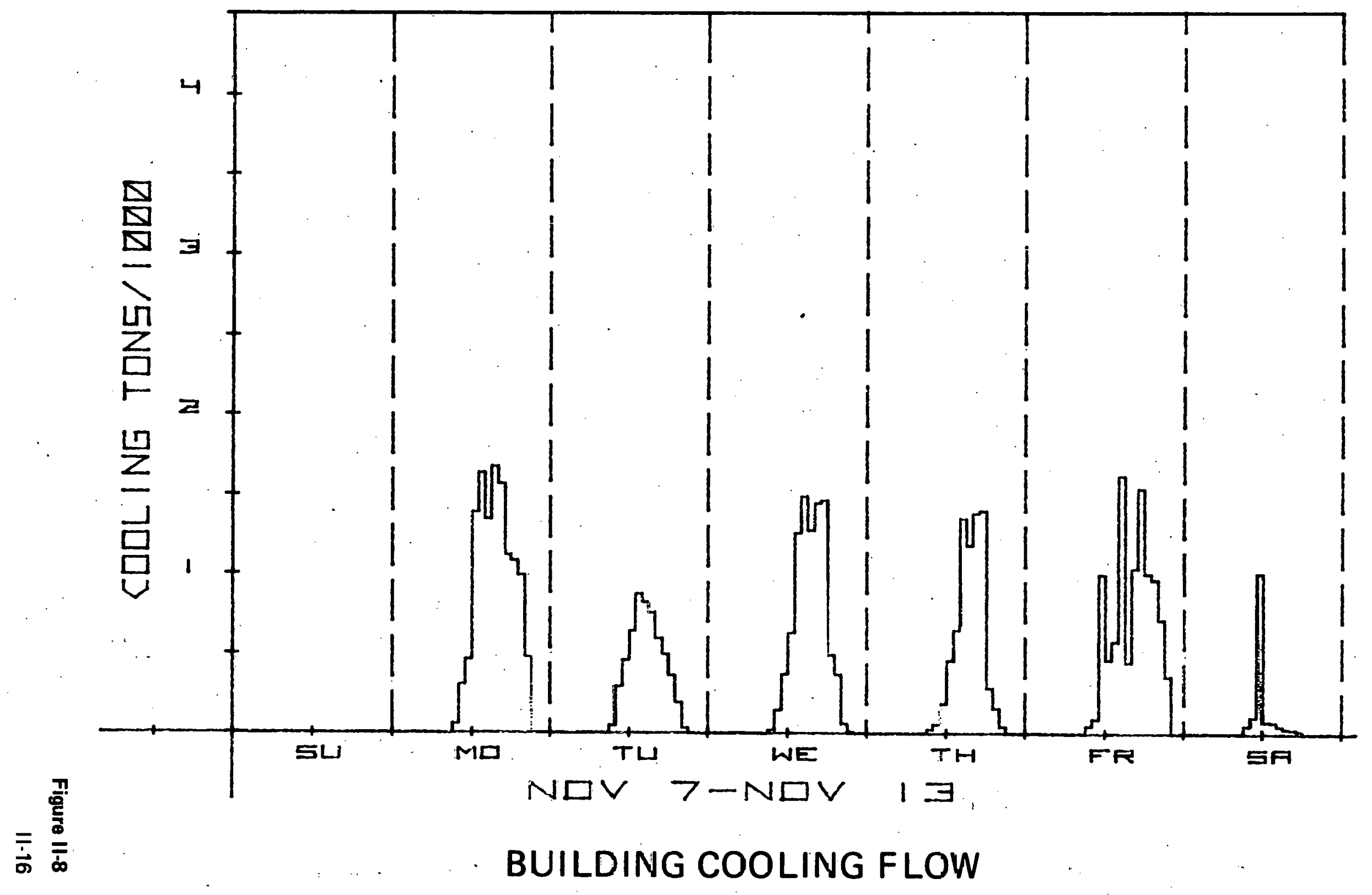




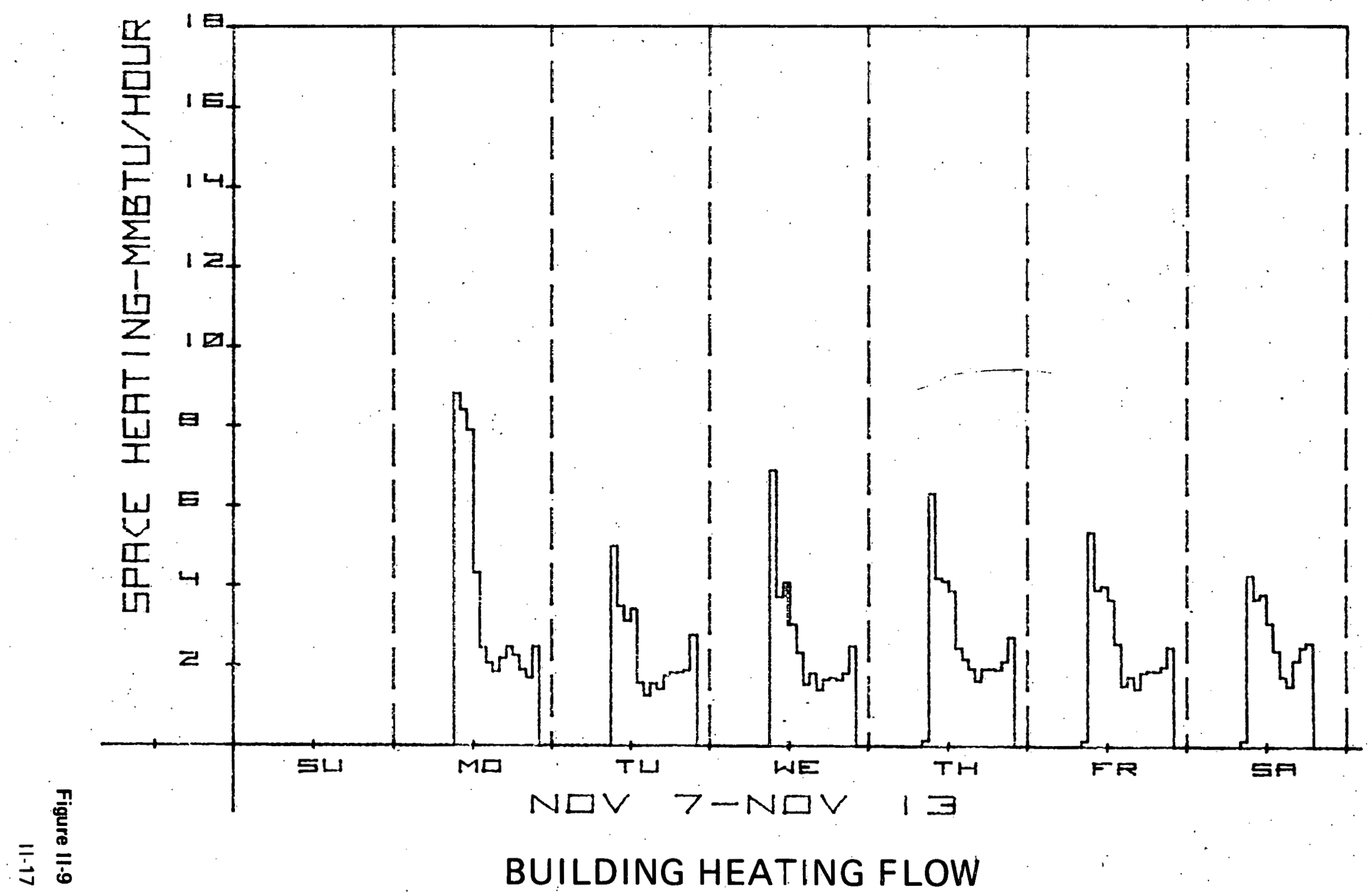




\section{DESCRIPTION OF CONVENTIONAL SYSTEM}

\section{A. DEFINITION OF CONVENTIONAL SYSTEM}

It was agreed that the base used to compare cost, energy use and pollution produc tion of the various options would be that used and produced by the development if it were built by the developer in whatever legal and satisfactory manner he wished.

The hypothetical Conventional System was then assumed to consist of systems and components that followed the typical construction practice that prevails in Southern California for Projects of this nature. These were modified somewhat to conform with the applicable sections of the pending State of California Energy Conservation Standards for New Nonresidential Buildings.

The Conventional Systems, in this report, were based on the following groups of equipment:

1. Department Stores, each (Penney's, Broadway):

a. Cooling and Heating Equipment: Centrally located electric drive aircooled screw-type refrigeration and oil-fired hot water boilers for space and domestic water heating, serving the main areas of the stores.

b. Air Moving Equipment: Variable air volume economy cycle air conditioning units with variable volume reheat terminal units.

c. Specialty Areas (restaurants, beauty parlor, tailor shop): Self-contained air conditioning units same as for tenant retail shops, below.

2. Tenant Retail Shops, each:

a. Cooling and Heating Equipment: Self-contained air-cooled roof mounted package air conditioner, with variable air volume feature and economy cycle.

b. Air Distribution: Variable air volume electric reheat terminal. Heating for glassed areas only.

c. Domestic Hot Water: Local electric domestic water heater.

3. Mall: Multiple self-contained air-cooled roof mounted package air conditioners, with variable air volume, electric heating and economy cycle features.

4. Office Buildings, each: Same as department stores. 


\section{B. ENERGY CONSUMPTION}

1. The AXCESS computer program was used to analyze the yearly energy consumption for the Conventional System. This was done in an AXCESS program run of February 28, 1976.

2. This computer run was also used to simultaneously analyze the yearly energy consumption for a Central Cooling/Heating Plant to serve the community, and is discussed in this report in the succeeding Section IV.

3. In order to measure and analyze the energy used for electrical power, cooling, hcating and domestic water heating for the Cuilventiunal Systern for the various use areas of the building, various combinations of schemes and priIriary equipmirll sysierrs were selected to be analyzed by the AXLtSS pro. gram. These combinations are described and tabulated in Appendix F.

4. The average system heat rate used in this report, or in other words the heating value of electricity purchased from the utility company, the Pasadena Department of Water and Power, was determined by them to be 11,200 BTU/ $\mathrm{KWH}$ plus $5 \%$ in estimated distribution line losses to the site, resulting in $11,760 \mathrm{BTU} / \mathrm{KWH}$.

This means that electricity purchased from the power company grid is being generated at

$\frac{3413 \text { BTU/KWH Output (Equivalent Heat Rate) }}{19,700 \text { BTU/KWH Input }}=29 \%$ Efficienc.y

5. The total energy consumption of the Cnnventional System(s), as explained in detail in Appendix $F$, is summarized below:

\section{ENERGY SOURCE}

$\begin{array}{lrrr}\text { Electric Power } & 31,001,492 \mathrm{KWH} & 11,760 \mathrm{BTU} / \mathrm{KWH} & 36.5 \times 10^{10} \\ \text { Fuel Oil } & 32,250 \mathrm{GAL} & 139,000 \mathrm{BTU} / \mathrm{GAL} & 0.4 \times 10^{10} \\ & & \text { TOTAL USE } & 36.9 \times 10^{10}\end{array}$

CONVERSION FACTOR
TOTAL BTU

\section{c. ANNUAL COSTS OF CONVENTIONAL SYSTEM}

1. Capital Costs

The capital costs of mechanical and electrical equipment for the Coriventional System, described above, which would provide cooling, heating and domestic water heating, but not including fans and duct distribution or controls for various use areas of the community, were estimated. These estimates included a $15 \%$ general contractor mark-up and $11 \%$ annual escalation, and are tabulated in Appendix G. 
The total equipment cost as shown was

Add for permits and fees

Add for $5 \%$ construction management fee
$\$ 1,615,000$

100,000

80,800

$\$ 1,795,800$

\section{Annual Operating Cost}

This cost is arrived at from the combination of annual maintenance and energy cost. The cost of fuel is based on $\$ .345$ per gallon. Electrical costs were calculated on the basis of DWP Schedule G-2 plus present fuel adjustment charges $(\$ .015 / \mathrm{KWH})$. Annual maintenance costs were estimated from manu facturer's data for major overhauls and estimated housekeeping and routine maintenance. Again, fan energy was included as it would be a cost common to all systems.

These figures are tabulated below, and in the comparison with the TIES systems, later on in the report, in Section V:

\begin{tabular}{|c|c|c|c|c|c|}
\hline SCHEME & $\begin{array}{c}\text { FUEL/YR } \\
\text { (OIL) } \\
\text { GAL }\end{array}$ & $\begin{array}{c}\text { ANNUÁL } \\
\text { FUEL } \\
\text { COST } \\
\$\end{array}$ & $\begin{array}{c}\text { ANNUAL* } \\
\text { ELEC. } \\
\text { COST } \\
\$\end{array}$ & $\begin{array}{c}\text { ANNUAL } \\
\text { MAINT. } \\
\text { COST } \\
\$\end{array}$ & $\begin{array}{c}\text { ANNUAL } \\
\text { OPER. } \\
\text { COSTS } \\
\$\end{array}$ \\
\hline $\begin{array}{l}\text { Conventional } \\
\text { System }\end{array}$ & 32,250 & 11,100 & 328,600 & 40,000 & 379,700 \\
\hline
\end{tabular}

\section{Annual Owning Cost}

The annual owning cost was computed on the following base:

- A 20-year capital recovery at $9 \%$ interest

- 20-year equipment life for large equipment

- 12-year equipment life for small equipment

- $1 \%$ Insurance costs

- $\quad 2.5 \%$ Property Tax Costs

On this basis, with $\$ 1,795,800$ invested in heating and cooling apparatus, the average annual owning cost would be $\$ 361,500$ and the total annual owning and operating cost would be $\$ 741,200$.

This figure is repeated in the comparison with the TIES systems, later on in the report, in Section V. 


\section{DESCRIPTION OF CENTRAL COOLING/HEATING PLANT SYSTEM}

\section{A. DEFINITION OF CENTRAL PLANT SYSTEM}

The Central Plant System, as used in this report, is defined as a central cooling/ heating plant that includes the equipment necessary to provide cooling and heating for the entire Energy Using Community. This would be a "standard" central plant, one that would only provide the above utilities, as opposed to a plant that would also produce electricity as in the case of the TIES System plants discussed in Section V.

It was assumed that the central plant would be located in the lower level of Parking Structure Parcel ' $H$ ' adjacent to the retail center.

The Central Plant System, was assumed to include the following equipment:

\section{Cooling Equipment}

Three hermetic electric driven centrifugal compressor water chilling units of 1000 tons refrigeration capacity each, piped in parallel, along with a threecell induced draft cooling tower and three condenser water pumps will provide $42^{\circ} \mathrm{F}$ chilled water. One primary chilled water pump for each chiller to circulate water to a primary piping loop in the central plant, and a variable flow pumping system to circulate chilled water from the primary piping loop to distribution mains supplying the tenant and common areas.

\section{Heating Equipment}

Hot water for heating produced by two packaged low pressure scotch marine, oil fired hot water boilers, each with an output of 10,000,000 BTU/HR. (One boiler is standby.) One hot water pump for each boiler to circulate water from the boilers to the distribution mains supplying the tenant and common areas.

\section{Domestic Water}

Domestic hot water produced by two packaged low pressure scotch marine oil fired hot water boilers, each with an output of 400,000 BTU/HR (one boiler is standby). One hot water pump for each domestic hot water boiler to circulate water from the boilers to a storage tank. Distribution mains to supply the tenant and common areas from the tank with a recirculating loop and pump to connect from the end of the distribution main back to the Plant, to maintain $120^{\circ} \mathrm{F}$ hot water temperature in the main. 


\section{B. ENERGY CONSUMPTION}

1. The AXCESS computer program was used to analyze the yearly energy consumption for the Central Plant System. This was done in an AXCESS program run of February 28, 1976.

2. This computer run was also used to simultaneously analyze the yearly energy consumption for the Conventional System to serve the community, and is discussed in this report in the preceding Section III.

3. The energy used for electrical power, cooling, heating and domestic water heating for the Central Plant System was measured by the AXCESS program under Scheme D, as described and tabulated in Appendix F.

4. Electricity purchased from the power company grid is generated at $29 \%$ efficiency (as described in Section III).

5. The total energy consumption of the Central Plant System detailed in Appendix $F$ is summarized below:

ENERGY SOURCE

Electric Power

Fuel Oil
AMOUNT/HR

$27,828,336 \mathrm{KWH}$

\section{CONVERSION}

FACTOR $11,760 \mathrm{BTU} / \mathrm{KWH}$
$139,000 \mathrm{BTU} / \mathrm{GAL}$

TOTAL USE

\section{TOTAL}

BTU

$32.7 \times 10^{10}$

$1.2 \times 10^{10}$

$33.9 \times 10^{1 n}$

\section{ANNUAL COSTS OF CENTRAL PLANT SYSTEM}

1. Capital Costs

The capital costs of mechanical and electrical equipment for the Central Plant System, described above, which would provide cooling, heating and domestic water heating for various use areas of the community, were csti mated. These estimates included a $15 \%$ general contractor mark-up and $11 \%$ annual escalation, and are tabulated in Appendix $\mathrm{H}$.

The plant structure and utilities

$\$ 490,000$

The total mechanical and electrical equipment cost

$1,937,000$

Add for permits and fees 100,000

Add for $5 \%$ construction management fee 121,400

Add for administration by PRA 122,000

TOTAL $\$ 2,770,400$ 


\section{Annual Operating Cost}

This cost is arrived at from the combination of annual maintenance and energy cost. The cost of fuel is based on $\$ .345$ per gallon. Electrical costs were calculated on the basis of DWP Schedule G-2 plus present fuel adjustment charges $(\$ .015 / \mathrm{KWH})$. Annual maintenance costs were estimated from manufacturer's data for major overhauls and estimated housekeeping and routine maintenance.

These figures are tabulated below, and in the comparison with the TIES systems, later on in the report, in Section V:

\begin{tabular}{|c|c|c|c|c|c|}
\hline SCHEME & $\begin{array}{c}\text { FUEL/YR } \\
\text { (OIL) } \\
\text { GAL }\end{array}$ & $\begin{array}{c}\text { ANNUAL } \\
\text { FUEL } \\
\text { COST } \\
\$\end{array}$ & $\begin{array}{c}\text { ANNUAL } \\
\text { ELEC. } \\
\text { COST } \\
\$\end{array}$ & $\begin{array}{c}\text { ANNUAL } \\
\text { MAINT: } \\
\text { COST } \\
\$ \$\end{array}$ & $\begin{array}{c}\text { ANNUAL } \\
\text { OPER. } \\
\text { COSTS } \\
\$\end{array}$ \\
\hline $\begin{array}{l}\text { Central Plant } \\
\text { System }\end{array}$ & 87,141 & 30,100 & 152,600 & 53,000 & 235,700 \\
\hline
\end{tabular}

\section{Annual Owning Cost}

The annual owning cost of the Central Plant System is calculated on the basis of a 22 year life and $7 \frac{1}{2} \%$ borrowing rate. A $5 \%$ contingency reserve and. $5 \%$ investment income loss was added to the loan for the 12 month construction period. Insurance at $1 \%$ is included, but property tax is exempt to PRA.

The total annual owning cost thus computed was $\$ 367,900$ and the total annual owning and operating cost is $\$ 603,600$.

This figure is repeated in the comparison with the TIES systems, later on in the report, in Section V. 


\section{EXAMINATION OF TIES SYSTEMS}

\section{A. METHOD OF APPROACH}

\section{Initial Examination of Energy Systems and Project Constraints}

a. At the start of this study an attempt was made to consider all possible known sources of fuels, energy and fuel, processing and energy conversion sub-systems which could serve the energy needs of a community. This initial investigation then evaluated the practicality of applying these known sub-systems to be used in an energy plant serving the specific community under study located in Pasadena, California.

b. Since the actual project construction schedule, location and budget of thise energy plant imposed certain limitations and constraints, the total list of known sub-systems was then reduced to a smaller group of subsystems which were considered project viable.

c. The criteria used in evaluating the viability of sub-systems were:

(1) Number 1 - Commercial Availability: This means sub-systems and their components which are presently produced commercially and have a proven record of efficient performance under operation in at least several existing installations throughout the world.

In the case of raw fuel or energy sub-systems, commercial availability would mean obtainability, such as from a utility company or mine, to the site of the energy using community under study.

(2) Number 2 - Environmental Constraints, including:

(a) Impact on air quality - must be approved by the Southern California Air Pollution Control District.

(b) Impact on community ambient noise levels.

(c) Impact on community radiation levels.

(3) Number 3 - Cost Constraints: The maximum initial cost of the project's energy plant installation was established by PRA and ERDA to be $\$ 15,000,000$. The cost of any sub-system considered for the project had to be low enough to fit into this budget figure.

(4) Number 4 - Project Construction Schedule: All sub-systems and their components had to be obtainable in time to meet the project's design and construction schedule of 18 months to completion and useful service. 
(5) Number 5 - Site Space Constraints: All sub-systems and their components had to be able to fit onto and into the proposed site in downtown Pasadena, California.

(6) Number 6 - Interrelationship of Sub-Systems: All sub-systems considered had to be viable in relationship to all other project subsystems simultaneously considered in a total system.

d. Known Sub-Systems Considered and Evaluated: The following is a list of the known sub-systems considered for evaluation and the criteria, if any, which eliminated them from further consideration:

\section{SUB.SYSTEM}

RAW FUEL/ENERGY

SUB-SYSTEMS

Coal

Oil

Nalural Gas

Solid Waste

Liquid Waste

Solar

Nuclear

Tidal

Wind Power

FUEL PHOCESSING

AND/OR

CONVERSION SUB-SYSTEMS

Coal Gasification

Incinerátión

Solar Energy Collector

Anaerobic Digestion

\section{ENERGY CONVERSION}

SUB-SYSTEMS

Boiler with Steam

Turbine (Rankine

Cycle)

Diesel Cycle

\section{ELIMINATING CRITERIA I.D. NUMBER}

5

2

None

1

2,3 and 5

3,5 and 6

1,3 and 5

(considered in this study for supplementing the low potential heat requirements for domestic hot water)

$1,2,3,4,5$ and 6

$1,3,4$ and 5

$1,3,4$ and 5
$1,2,3,4,5$ and 6

$2,3,4$ and 5

5 (used in limited capacity in this study as explained above)

$2,3,4$ and 5

None

None 
Combustion (Gas) Turbine

(Brayton Cycle)

None

Organic Rankine Cycle

1

Externally. Fired

Closed Brayton Cycle

Sterling Cycle

1

1

THERMAL CONVERSION

SUB-SYSTEMS

Diesel Engine Heat

Recovery

None

Combustion Turbine

Heat Recovery

Refrigeration Cycle

Heat Recovery

None

None

Compressive

Refrigeration

None

Absorption

Refrigeration

Combined Cycle

Steam Turbines

None

None

THERMAL STORAGE

SUB-SYSTEMS

Chilled Water -

For Cooling

None

Hot Water -

For Heating

None

e. The remaining sub-systems, those not eliminated by the evaluating criteria, were considered viable for the TIES concept project. These are specifically analyzed in the remainder of this study.

2. Energy Cycle Relationships

a. All engine cycles have four major phases:

(1) A heat input phase, during which heat enters the cycle at high potential (high temperature and pressure).

(2) A work output phase, during which work is performed by the cycle to produce power. 
(3) A heat rejection phase, during which low potential heat must be rejected from the cycle.

(4) A work input phase, during which the cycle is reinstated to its higher potential. Also included in this phase is the power requirements of equipment needed to drive cooling towers, air compressors, oil pumps, fuel pumps and other auxiliary power consuming units of the engine.

b. Heat recovery occurs only in phase (3), described above, and the recovered heat is available only at the potential that is inherent to the cycle during this phase. To benefit from the recovered heat, then, it is necessary to be able to use the heat at that potential level.

c. In a few cycles, such as a combustion turbine cycle, heat rejection takes place at a sufficiently high potential that a secondary engine cycle can

- be operated with reasonable efficiency to produce work (and power) from the waste heat. More commonly, however, the primary engine rejects heat at temperatures only 50 to $150^{\circ} \mathrm{F}$ above ambient, leaving a thermal potential too small to effectively produce work.

d. Normally, the creation of a heating media follows the first law of thermodynamics, that is that the amount of heat to raise the potential energy of the media is equal to the potential energy increase plus the losses that must occur in the heating process. Boilers and similar heating devices can seldom operate at efficiencies exceeding $80 \%$, and in the real world, boiler plants seldom operate above $70 \%$ efficiency. All that such heating plants do, is to raise the potential of a media to a given level so that heat transfer can occur and the input heat required will be 125 to $135 \%$ of the transferred heat. When the potential available in waste hcat is adequate tu meel the heat transfer needs, no further heat introduction is needed, and the heat introduced into the process noed only be the amount of heat transferred plus transmission losses. This makes heating a very logical candidate for waste heat utilization.

e. ' Cuuling, however, is a difterent process. Cooling is a work cycle of sorts, being more or less an engine cycle in reverse. See Figure V-1.

Cooling, then, has a work (or power) input phase which implies a need for high potential snurce for the work input nhnse. The exceupliun to this rule is the absorption refrigeration cycle which can perform the bulk of work input with fairly low potential heat $\left( \pm 225^{\circ} \mathrm{F}\right)$. The efficacy of this cycle is low, however, requiring about 20,000 BTU per. ton-hour as compared to the compressive refrigeration cycle which demands a high potential energy input, but consumes only about 3,000 BTU per ton-hour of refrigerating effect produced. 


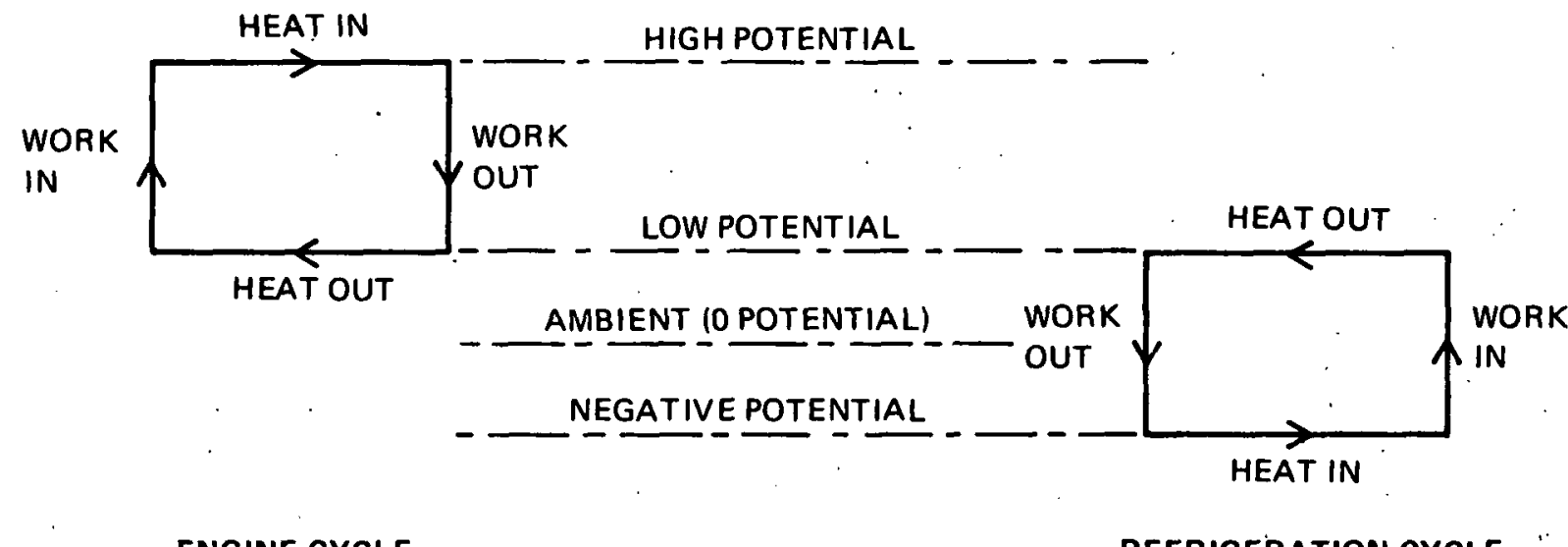

ENGINE CYCLE

REFRIGERATION CYCLE

Figure V-1

ENGINE AND REFRIGERATION CYCLES

f. Among the options available to the designer of an eneray svstem is to. use high potential waste heat to drive the more energy efficient compressive cycle refrigeration machine or to use this energy to drive a second stage electric generator and live with the low efficiency absorption cycle which only needs low potential energy.

g. Regardless of the potential of the waste energy, the objective is to put as much energy to beneficial use as possible. To accomplish this end, the Total Energy System designer should seek cycles that most closely produce a ratio of work output (power production) to available heat output (recoverable waste heat at useable potential) which most closely approximates the needs of the energy using facility.

h. The problem in typical total energy applications is that this ratio is not constant. For example, the amount of recovered energy needed for space heating and cooling both diminish considerably in a moderate climate while demand for electric power barely changes with respect to the weather. Similarly, peak demand for heat generally occurs during the morning warm-up cycle which occurs before the building is occupied, lights turned on, etc., so that needed power generation is very low.

j. The second major problem with the typical total energy system is that while the energy use of the auxiliary equipment is a small fraction ( 5 to $7 \%$ ) of the fuel energy input to the cycle when operating at design capacity, design capacity is seldom achieved. When the cycle is operated at part load, the auxiliary power requirement does not diminish nearly 
as much as the load and therefore becomes an increasingly larger energy loss as load goes down. Because major power demand fluctuations can and do occur in many buildings this factor becomes an important part of the hour-by-hour analysis.

\section{TIES Concept Advantages}

The TIES concept can minimize these two outstanding problems by incorporating the following major departures from earlier total energy arrangements:

a. Grid Tie-in

By delivering power to the electric utility company's grid rather than to the load, the need for continuous balance between power and thermal flows is eliminated. This permits the prime movers to he loanded in ac. cordance with thermal rather than power flows, and thus assurcs that the waste heat produced will be usefully consumed. It is not even necessary to match power generation to demand nor is it necessary to be concerned about the ratio of work to heat output. There remain, however, certain problems.

(1) Thermal requirements in many applications will frequently drop to very low values with the result that much prime mover operation occurs at well below optimum efficiency.

(2) Thermal flows can change rapidly, particularly when major energy r.nnsı!ming apparatus is turned off or on. Control and system response problems are introduced by this situation that are not easily solved.

(3) At times, thermal loads below the turn-down capability of the primc mover con exist, resul liriy in cyclic uperatlon. This is not only damaging to equipment but efficiency is significantly reduced.

b. Thermal Storage

All the above problems can be reduced or eliminated by introducing thermal storage into the cycle.

(1) Thermal storage offers the opportunity to eliminate part-load operation, as well as to adjust the operating hours of the plant. Utilizing a linearly stratified tank approach with supply temperature maintained at one end and return at the other, it is possible to utilize the design system temperature differential for storage. For this study, $16^{\circ} \mathrm{F}$ was assumed for chilled water, resulting in $16 \times 8.33=133.3 \mathrm{BTU}$ of storage per gallon or 90 gallons for each ton-hour stored. 
(2) By allowing the system to run more hours, the components of the system can be made smaller. On the worst cooling day evidenced by the energy analysis (August 13). the building required about 30,700 ton-hours of cooling, peaking at 2,952 tons. A 1,278 ton machine running at full capacity over a 24 -hour period would produce the same ton-hours. It would be severely overloaded much of the time, but the deficiency would come out of storage. During periods when the building demand is less than the machine output, or when the building systems are turned off, the stored cooling is replaced. See Figure V-2.

(3) Electric power generation is not required to match the user's power demand in the TIES concept, but is sized solely to produce the thermal requirements of the system. In the case study, thermal input required for the refrigeration equipment exceeds that required for heat by a considerable margin, so the refrigeration system thermal input was used as the basis for sizing electric power generating equipment and waste heat boilers.

(4) The result of large storage systems is that the size, and therefore the cost, of all the equipment reduces in direct relation to the size of the refrigeration system, which creates a net first cost benefit.

(5) Storage can also be used to control power peaks and the method deserves consideration. If the cooperating utility company did not wish to accept power into its distribution grid except during periods of maximum system demand, and identified that period, for example as 12 noon to 8 p.m., a 3,835 ton refrigeration plant would be able to produce the needed daily ton-hours within the 8-hour period - 10,800 ton-hours of storage (972,000 gallons) would be required to serve the load that occurs before or after those hours. While this increases the size and initial cost of all apparatus, the utility may be willing to pay the owner considerably more for power produced only during a fixed period of the day.

Figure $V-3$ describes the refrigeration machine sizes, maximum run hours on the hottest day and minimum storage sizes required for project and typical calculations are included in Appendix $\mathrm{J}$.

c. Other Storage Considerations:

Other fartors involving storage are as follows:

(1) It may be desirable to store only the heating media, depending on its temperature, pressure and specific heat characteristics, in order to reduce the volume requirement, and install a conventional cooling plant that withdraws the heat in relation to load demand. 


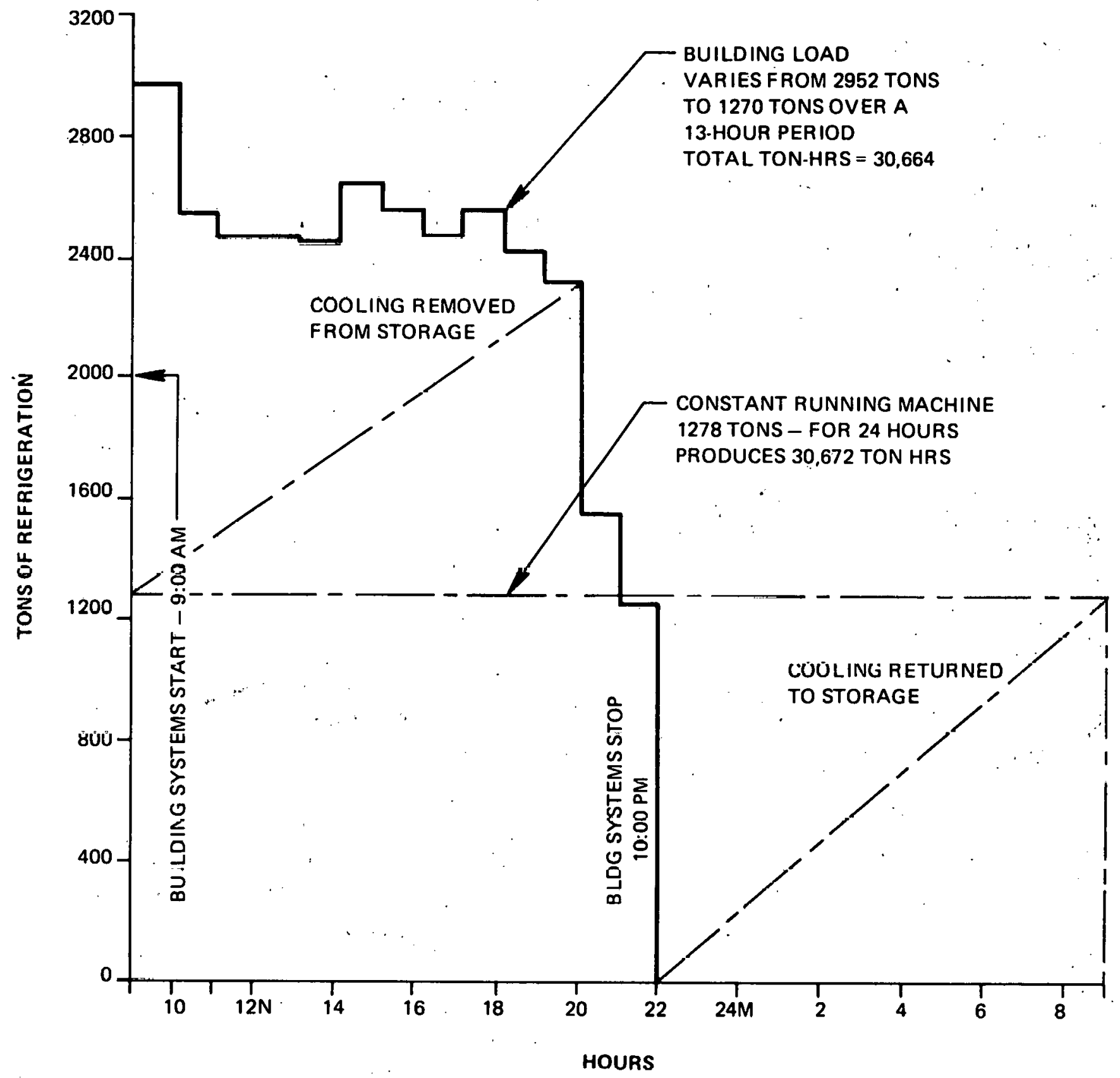

Figure V-2

WORST CASE BUILDING COOLING LOAD - (AUGUST 13) 


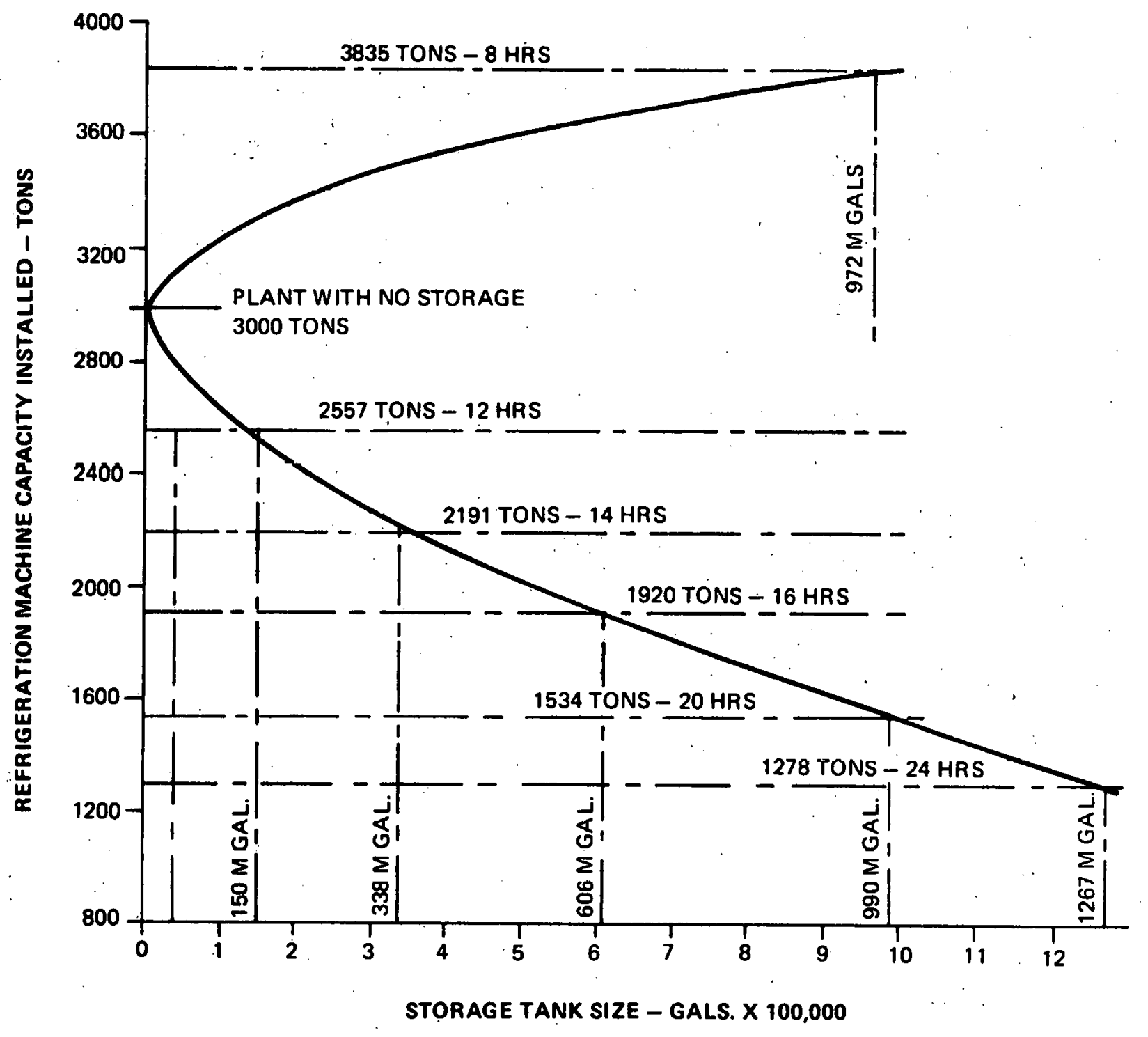

Figure V-3

REFRIGERATION MACHINE OPERATION vS. STORAGE TANK SIZE 
(2) If solid or liquid waste is being processed in the plant for recovery of energy the heat thus res.nvered ran he similarly stored for later use as demand may indicate. The integration of waste heat recovery with total energy has been studied under the Multiple Integrated Utility Systems (MIUS) Program being directed by the Department of Housing and Urban Development.

\section{B. TIES SYSTEMS STUDIED}

\section{Systems Studied}

The specific arrangements of sub-systems selected for detailed analysis for the TIES systems, are as follows:

a. Dicsel Enginc System (Scheme Group 1)

To produce heat, the thermal conversion sub-system which is most applicable to heat recovery from prime mover units, is single package heat recovery units, which are a type of heat exchanger, which recover heat at 15 psig steam pressure at $2 b U^{\circ} r$. I his is a sutticient temperature for space heating and domestic hot water heating. For refrigeration purposes it is applicable to absorption refrigeration sub-systems only, since 15 psig saturated steam has too low a potential for practical use to drive compressive refrigeration, or for combined cycle power generation. This scheme, or arrangement, is illustrated in Figure V-4, and described and tabulated in Tablc $V 1$, and identificd as Echemes 1A through 1E. Scheme $1 A$ has ro themal storage. Scherites 1B through 1E have in. creasing amounts of storage.

b. Combustion Turbine System (Scheme Groups 2 \& 4)

Combustion turbines operate on the thermodynamic cycle called the Open Brayton Cycle. Heat produced by thermal conversion sub-system components used to recover heat from combustion turbines, may reach $400 \mathrm{psig}, 500^{\circ} \mathrm{F}$ superheated steam. This signifies the ability to recover high-grade heat, that which has the potential to perform work to drive generators or other high temperature energy convertors, from the combustion turbine.

Since either compressive refrigeration, using steam turbine drive, or absorption refrigeration may be used as the cooling thermal converșion sub-systems, two arrangements are analyzed with this prime mover.

(1) The first, Scheme Group 2, with steam turbine refrigeration drive, the most efficient arrangement employs a condensing turbine to drive the chillers. When a requirement for heating exists, a backpressure steam turbine generator produces electric power, serving in effect as a pressure reducing valve for the high grade heat 


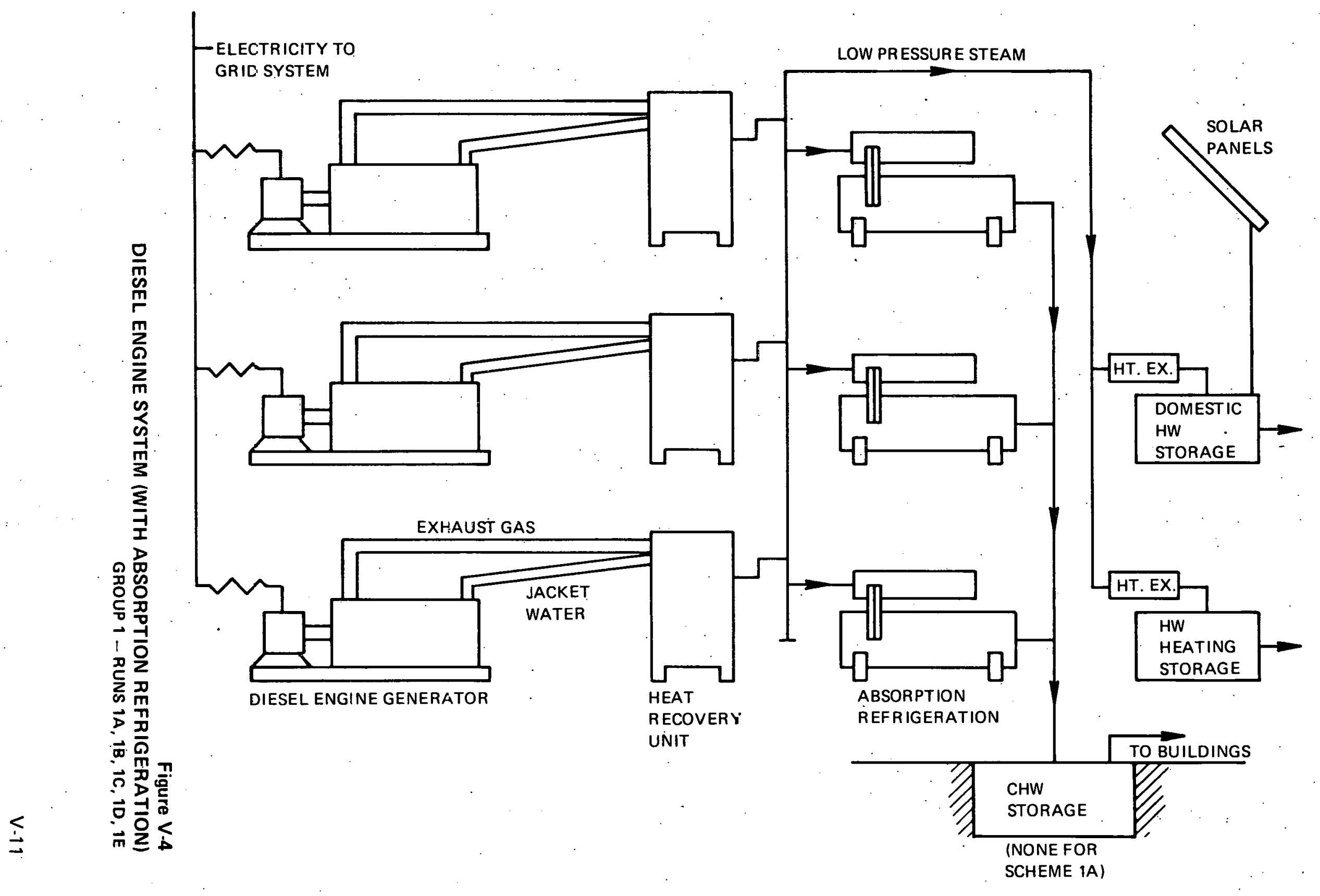


GROUP 1 - DIESEL ENGINE SYSTEM

(WITH·ABSORPTION REFRIGERATION)

\begin{tabular}{|c|c|c|c|c|c|c|c|c|c|}
\hline $\begin{array}{l}\text { RUN } \\
\text { NO. }\end{array}$ & $\begin{array}{l}\text { INSTALLED } \\
\text { CHILLED } \\
\text { WATER } \\
\text { STORAGE } \\
\text { GALLONS } \\
\text { (I) }\end{array}$ & $\begin{array}{l}\text { INSTALLED } \\
\text { REFRIG. } \\
\text { ERATION } \\
\text { TONMAGE } \\
\text { (2) }\end{array}$ & $\begin{array}{l}\text { INSTALLED } \\
\text { ABSORPTION } \\
\text { REFRIG- } \\
\text { ERATION- } \\
\text { MACHINES } \\
\text { WO. @ TONS } \\
\text { (3) }\end{array}$ & $\begin{array}{l}\text { STEAM FLOW } \\
\text { REQUIRED } \\
\text { PER AB- } \\
\text { SORPTION } \\
\text { MACHINE } \\
\text { LB/HR } \\
\text { (4) }\end{array}$ & $\begin{array}{l}\text { WASTE } \\
\text { HEAT } \\
\text { UTILI. } \\
\text { ZATION } \\
\text { FACTOR } \\
\text { (5) }\end{array}$ & $\begin{array}{l}\text { EQUIVALENT } \\
\text { STEAM FLOW } \\
\text { REQUIRED } \\
\text { FROM HEAT } \\
\text { RECOVERY } \\
\text { UNIT LB/HR } \\
\text { (6) }\end{array}$ & $\begin{array}{l}\text { DIESEL ENGINE } \\
\text { HEAT } \\
\text { RECOVERY } \\
\text { RATE LB/HR } \\
\text { PER KW } \\
\text { GENERATED } \\
\text { (7) }\end{array}$ & $\begin{array}{l}\text { INSTALLED } \\
\text { DIESEL } \\
\text { ENGINE } \\
\text { GENERATOR } \\
\text { SETS } \\
\text { NO. @ KW } \\
\text { (8) }\end{array}$ & $\begin{array}{c}\text { INSTALLED } \\
\text { HOT WATER } \\
\text { STORAGE } \\
\text { GALLONS } \\
\text { (9) }\end{array}$ \\
\hline 1A & $\mathbf{a}$ & 3,000 & $4 @ 750$ & 13,500 & .90 & 15,000 & 4.18 & $4 @ 3,589$ & 0 \\
\hline 1B & 370,000 & 2,190 & 3 @ 730 & 13,140 & .92 & 14,283 & 4.18 & $3 @ 3,417$ & 53,000 \\
\hline $1 \mathrm{C}$ & $65 a, 000$ & 1,920 & 3 @ 640 & 11,520 & .93 & 12,387 & 4.18 & $3 @ 2,963$ & 46,000 \\
\hline $1 D$ & $1,100,000$ & $1, \equiv 60$ & $3 @ 520$ & 9,360 & .94 & 9,957 & 4.18 & $3 @ 2,382$ & 40,000 \\
\hline $1 E$ & $1,400,000$ & $1, \overline{290}$ & $3 @ 430$ & 7,740 & .95 & 8,147 & 4.18 & $3 @ 1,949$ & 40,000 \\
\hline
\end{tabular}

(4) Based on $18 \mathrm{lb} /$ ton-hoi, $r$ steam flow at full load.

(5) Allowance for more fraquent start-up loss for larger units, than =or small units which run more continuously.

(6) Equal (4) $\div(5)$.

(7) Average values from manufacturers data, interpclated for size range.

(8) Same number of diesek as absorftion refrigeration machines installed at $(6) \div(7)$.

$<\frac{\vec{N}}{\stackrel{0}{\frac{0}{0}}}$ 
recovered. The low potential turbine exhaust heat can then be used for building heating or supplemental domestic hot water heating. The resultant combustion turbine system is illustrated in Figure V-5 and described and tabulated in Table V-2, and identified as Schemes $2 A$ through $2 D$. In this and all succeeding schemes, SubScheme $A$ has minimum thermal storage and Sub-Scheme $D$ has maximum thermal storage.

(2) The second arrangement, Scheme Group 4, uses a backpressure steam turbine generator combined with absorption refrigeration. This arrangement allows the high potential heat from the prime mover heat recovery device to be directed to power generation. The resultant combustion turbine-combined cycle system is illustrated in Figure V-7, and described and tabulated in Table V-4, and identified as Schemes $4 A$ through 4D.

\section{c. Boiler/Steam Turbine System (Scheme Group 3)}

Steam boilers in conjunction with steam turbines operate on the thermodynamic cycle called the Rankine Cycle. This cycle, while it represents a form of total energy system, does not follow the TIES concept of waste heat recovery to meet site thermal needs. It was, however, included in the study of TIES central plants at the request of the Pasadena Department of Water \& Power. No waste heat is recovered from the prime mover, which in this case is the combination of a boiler and steam turbine. Rather the system consists of generation of high potential energy in the boiler, work production in a steam turbine with a turbine discharge of low-potential energy. The only application for the discharged low-grade BTU's in the cooling thermal conversion subsystem is in absorption refrigeration.

The resultant boiler/steam turbine system is illustrated in Figure V-6, and described and tabulated in Table V-3, and identified as Schemes $3 A$ through 3D. 


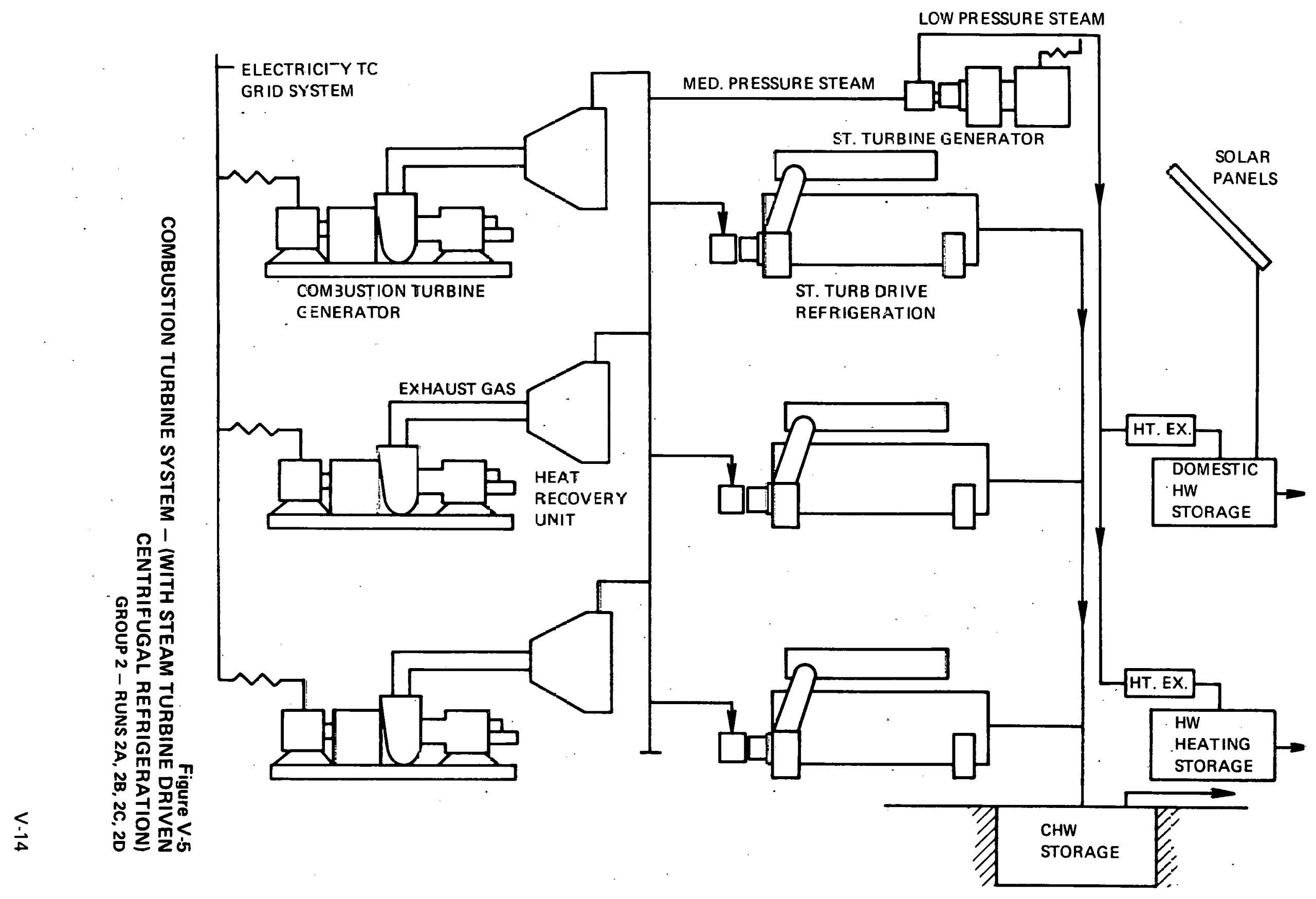


GROUP 2 - COMBUSTION TURBINE SYSTEM (WITH STEAM TURBINE DRIVEN CENTRIFUGAL REFRIGERATION)

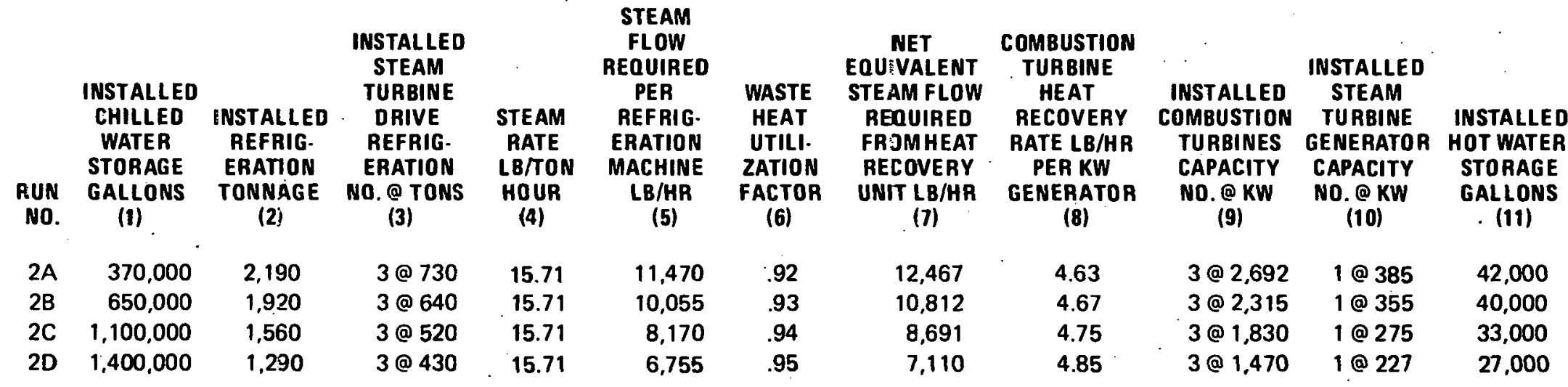

(4) At $400 \mathrm{PSIA}, 500^{\circ} \mathrm{F}$ inlet, 4" HG outlet, $51 \%$ net turbine efficiency, steam rate $=18.49 \mathrm{LB} / \mathrm{KW}, .85 \mathrm{KW} /$ Ton equivalent net drive ratio.

(5) Equals (3) $\times(4)$.

(6) Allowance for more frequent start-up loss for larger units than for smaller units which run more continuously.

(7) Equals (5) $\div$ (5)

(8) Average values from manufacturers data, interpolated for size range.

(9) Same number of combustion turbines as refrigeration machines, at (7) $\div(8)$.

(10) At $400 \mathrm{PSIA}, 500^{\circ} \mathrm{F}$ inlet, $20 \mathrm{PSIA}$ outlet, $51 \%$ net turbine efficiency (including gear and generator losses), steam rate $=29.74 \mathrm{LB} / \mathrm{KW}$. Using one steam turbine at same steam flow as one sefrigeration, equals $(5) \div 29.74$. 


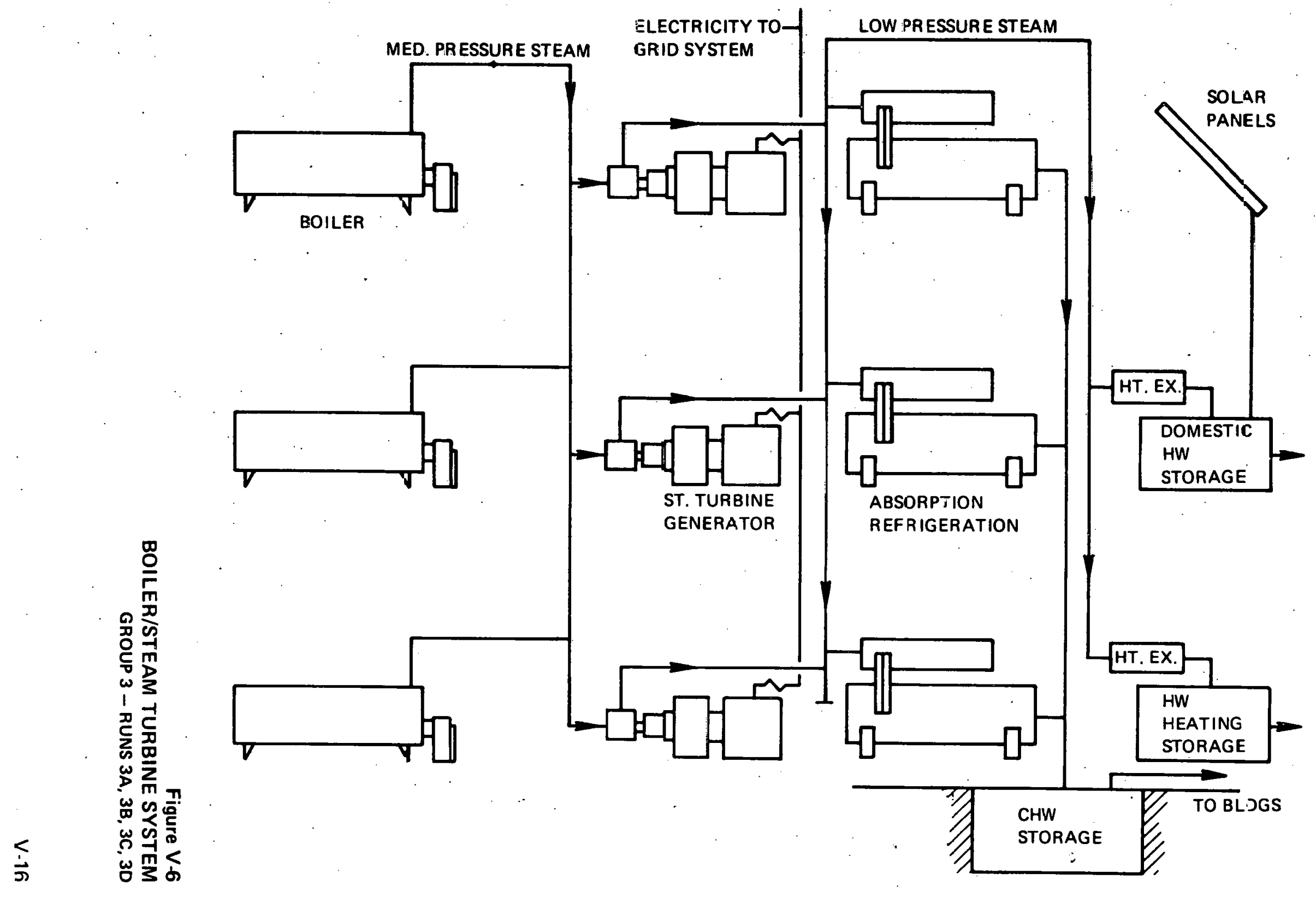




\section{GROUP 3 - DESCRIPTION OF BOILER/STEAM TURBINE SYSTEM}

\begin{tabular}{|c|c|c|c|c|c|c|c|c|}
\hline $\begin{array}{l}\text { RUN } \\
\text { NO. }\end{array}$ & $\begin{array}{l}\text { INSTALLED } \\
\text { CHILLED } \\
\text { WATER } \\
\text { STORAGE } \\
\text { GALLONS } \\
\text { (1) }\end{array}$ & $\begin{array}{l}\text { INSTALLED } \\
\text { REFRIG- } \\
\text { ERATION } \\
\text { TONNAGE } \\
\text { (2) }\end{array}$ & $\begin{array}{l}\text { INSTALLED } \\
\text { ABSORPTION } \\
\text { REFRIG. } \\
\text { ERATION } \\
\text { MACHINES } \\
\text { NO. @ TONS } \\
\text { (3) }\end{array}$ & $\begin{array}{l}\text { STEAM FLOW } \\
\text { REQUIRED } \\
\text { PER } \\
\text { ABSORPTION } \\
\text { MACHINE } \\
\text { LB/HR } \\
\text { (4) }\end{array}$ & $\begin{array}{l}\text { INSTALLED } \\
\text { STEAM } \\
\text { TU ZBINE } \\
\text { GENERATOR } \\
\text { CAPACITY } \\
\text { NO. @ KW } \\
\text { (5) }\end{array}$ & $\begin{array}{l}\text { HEAT } \\
\text { UTILIZATION } \\
\text { FACTOR } \\
\text { (6) }\end{array}$ & $\begin{array}{c}\text { INSTALLED } \\
\text { BOILERS } \\
\text { NO. @ LB/HR } \\
\text { (7) }\end{array}$ & $\begin{array}{c}\text { INSTALLED } \\
\text { HOT WATER } \\
\text { STORAGE } \\
\text { GALLONS } \\
\text { (8) }\end{array}$ \\
\hline $3 A$ & 370,000 & 2,190 & $3 @ 730$ & 14,052 & 3 @ 419 & .92 & $3 @ 15,275$ & 53,000 \\
\hline $3 B$ & 650,000 & 1,920 & 3 @ 640 & 12,320 & $3 @ 368$ & .93 & $3 @ 13,247$ & 46,000 \\
\hline $3 C$ & $1,100,000$ & 1,560 & $3 @ 520$ & 10,010 & 3@ 299 & .94 & 3 @ 10,649 & 38,000 \\
\hline 3D & $1,400,000$ & 1,290 & $3 @ 430$ & 8,278 & $3 @ 247$ & .95 & $3 @ 8,713$ & 31,000 \\
\hline
\end{tabular}

(4) Based on $19.25 \mathrm{lb} /$ ton-hour steam flow at full load, with wet steam from ti rbine into absorption machine.

(5) At 400 PSIA, $500^{\circ} \mathrm{F}$ inlet, $30 \mathrm{PSI}$. outlet, $51 \%$ net turbine efficiency, stean rate $=33.46 \mathrm{LB} / \mathrm{KW}$; at same steam flow as absorption machine, equals $(4) \div 33.46$.

(6) Allowarice for more frequent start-up loss. for larger units than for smaller $t$.nits which run more continuously.

(7) Equals (4) $\div(6)$. 


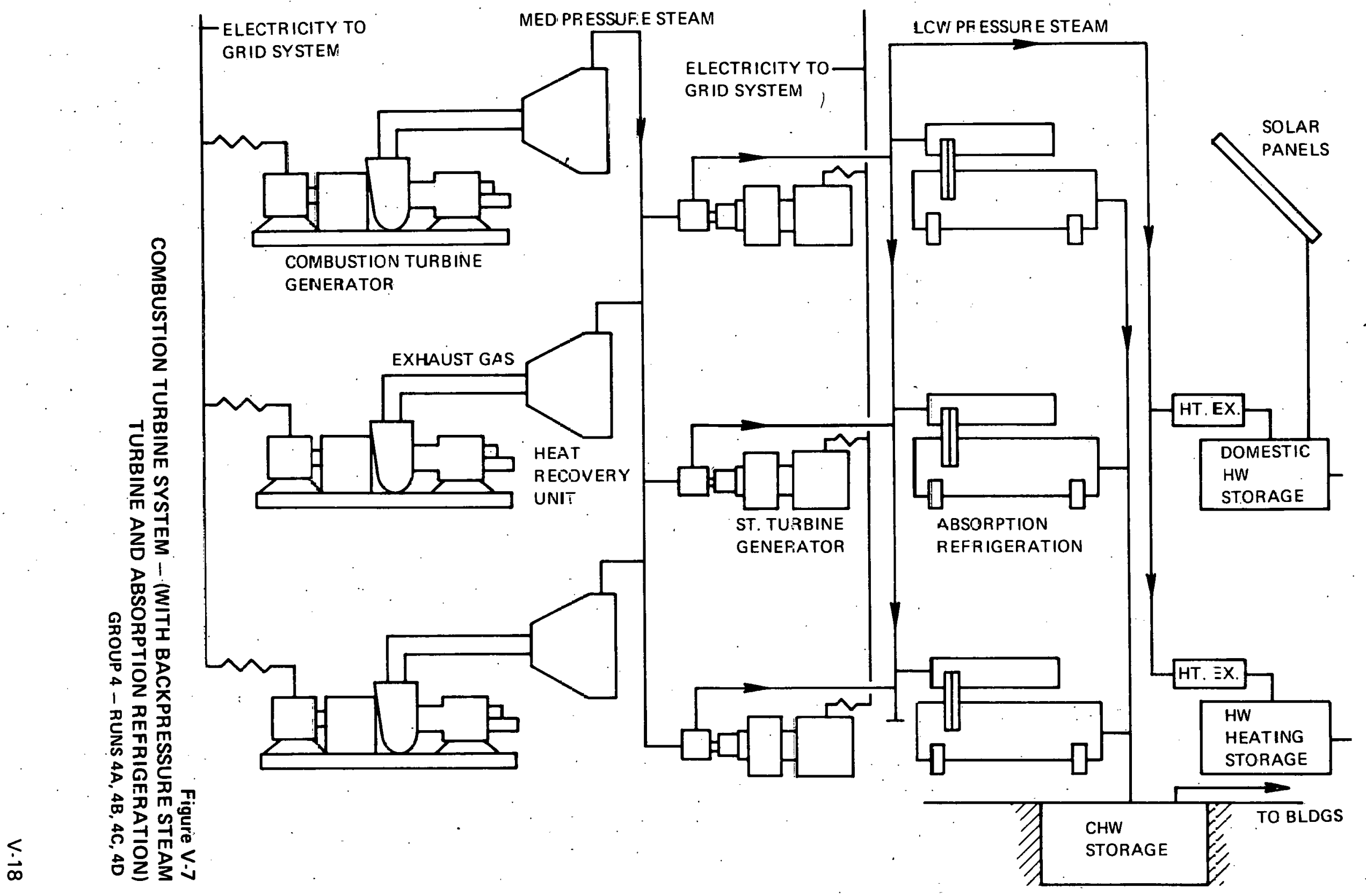


GROUP 4 - COMBUSTION TURBINE SYSTEM

(WITH BACKPRESSURE STEAM TURBINE AND ABSORPTION REFRIGERATION)

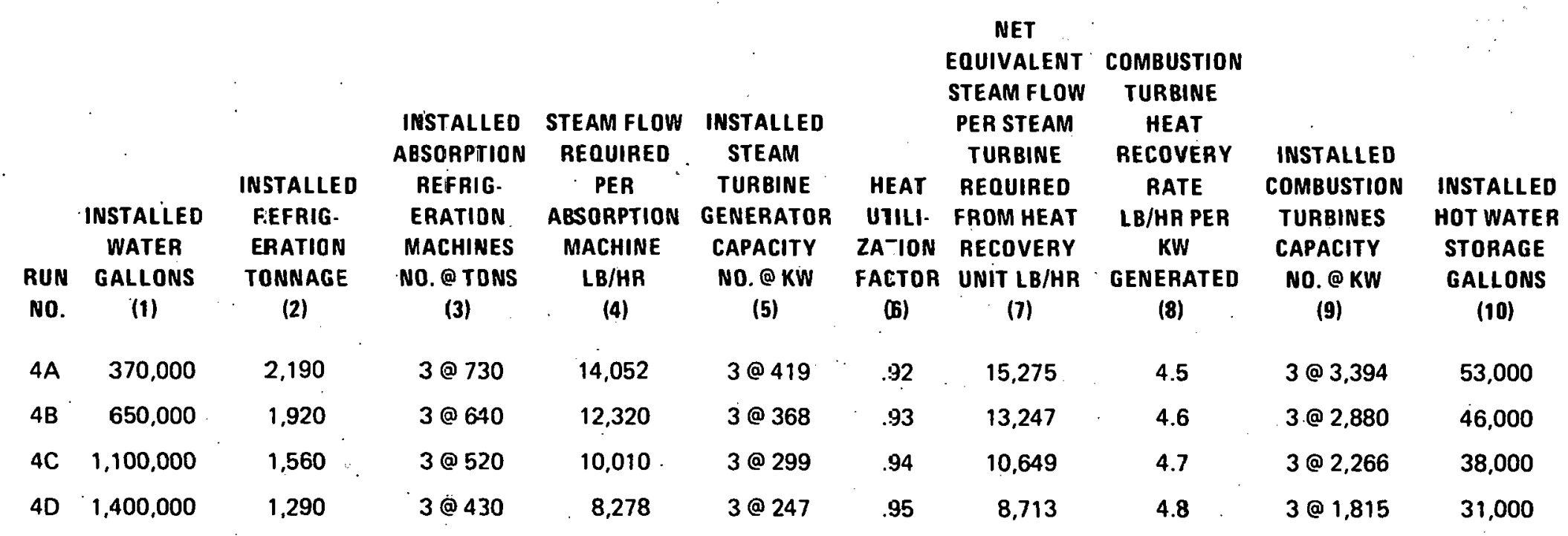

(4) Based on $19.25 \mathrm{lb} /$ ton-hour steam flow at full load with wet steam from turbire into absorption machine.

(5). At $400 \mathrm{PSIA}, 500^{\circ} \mathrm{F}$ inlet, $30 \mathrm{PSIA}$ outlet, $51 \%$ net turbine efficiency, steam rate $=33.46 \mathrm{LB} / \mathrm{KW}$, at same steam flow as absorption machine, equals $(4) \div 33.45$.

(6) Allowance for more frequent start-up oss for larger units, than for smaller uni-s which run more continuously.

(7) Equals $(4) \div(6)$.

(8) Average values from manufacturers data interpolated for size range.

(9) Equals $(7) \div(8)$. 


\section{Energy Analysis of TIES Systems}

a. General

Prior to inputing the data for the computer simulation, several assumptions were made for this arialysis. These are:

(1) In order to evaluate both initial cost and annual energy consumption impacts of storage for heating and cooling medium, it was decided to run each system or scheme with varying amounts of thermal storage. The chilled water and hot water thermal storage tanks were assumed to be underground concrete tanks, installed benoath tho floor of tho TIES Plant. The tank. walle, hottom and top would be constructed of 12 inch thick reinforced cuncrele, and the tanks would include concrete baffles to create a serpentirte flow path througli the tanks. The tank roofs would be insulated.

(2) For all schemes with storage, systems are designed so that component units operate at only full load output.

(3) The full load waste heat produced by generating equipment matched the full load thermal input demand of each thermal unit.

(4) The daily hours of operation input vary from the minimum of 13 hours of user load demand to a maximum of 24 hours.

(5) For considerations of reliability, at least three prime movers and refrigeration machines are considered in each scheme. This allows tho TIES plant to furnich at least two-thirds the required thermal demand on a peak day and most or all of it during the balance of

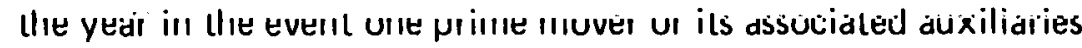
fails.

(6) The capacities selected are interpolations of manufacturers' data (see Appendix J). During preliminary design, which follows, the closest actual available commercial size of components were

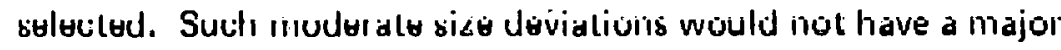
impact on the final results.

b. For each family of cycles analyzed, the AXCESS program was run four times, varying the installed power, refrigeration tonnage, and installed chilled water and hot water storage tank capacities for each run to determine the theoretical optimum plant capacity and fuel consumption. 
In addition, one run, the first (Scheme IA) was made with no storage as a basis for comparison.

\section{Other AXCESS Parameters}

\section{a. Refrigeration Machine Operation}

Refrigeration Machine start-stop operation was programmed to function with the storage tank in a manner that when warm water in the tank displaced cold water to an extent that the full running output of a machine for one-hour was required, one machine would start. As displacement continued, second and third machines similarly start. (See Figure V-8) The purpose of this control was to avoid short-cycling the equipment. For hot weather, however, an outdoor thermostat, set at $80^{\circ} \mathrm{F}$ starts two machines when the building systems start to avoid early depletion of the tank. Other, and perhaps more satisfactory control methods can be devised but this control was simple enough to be programmable to the computer.

b. Solar Energy System

The AXCESS program also analyzed the impact and benefits of a solar energy system. The solar energy system was analyzed on the basis of supplementing the domestic hot water energy needs of the project, as this application is most suited to solar collection.

c. Electrical System

Separate hourly summaries of electrical energy generated and energy consumed by both plant auxiliaries and the proposed development were tabulated. These were then arithmetically summed to obtain net electrical energy flow to or from the DWP grid system. The net amount of power consumed is equal to the gross amount of power delivered minus the gross amount returned to the grid.

d. Auxiliaries

Plant auxiliaries for each scheme were input in two groups; those such as the plant ventilation system which are constant, regardless of plant output, and those such as pumps which vary with the required plant output..

\section{ENERGY CONSUMPTION OF TIES SYSTEMS STUDIED}

\section{AXCESS Energy Analysis}

The previously described input parameters for each of the 17 TIES schemes described, were input to the AXCESS program. A summary of the results 


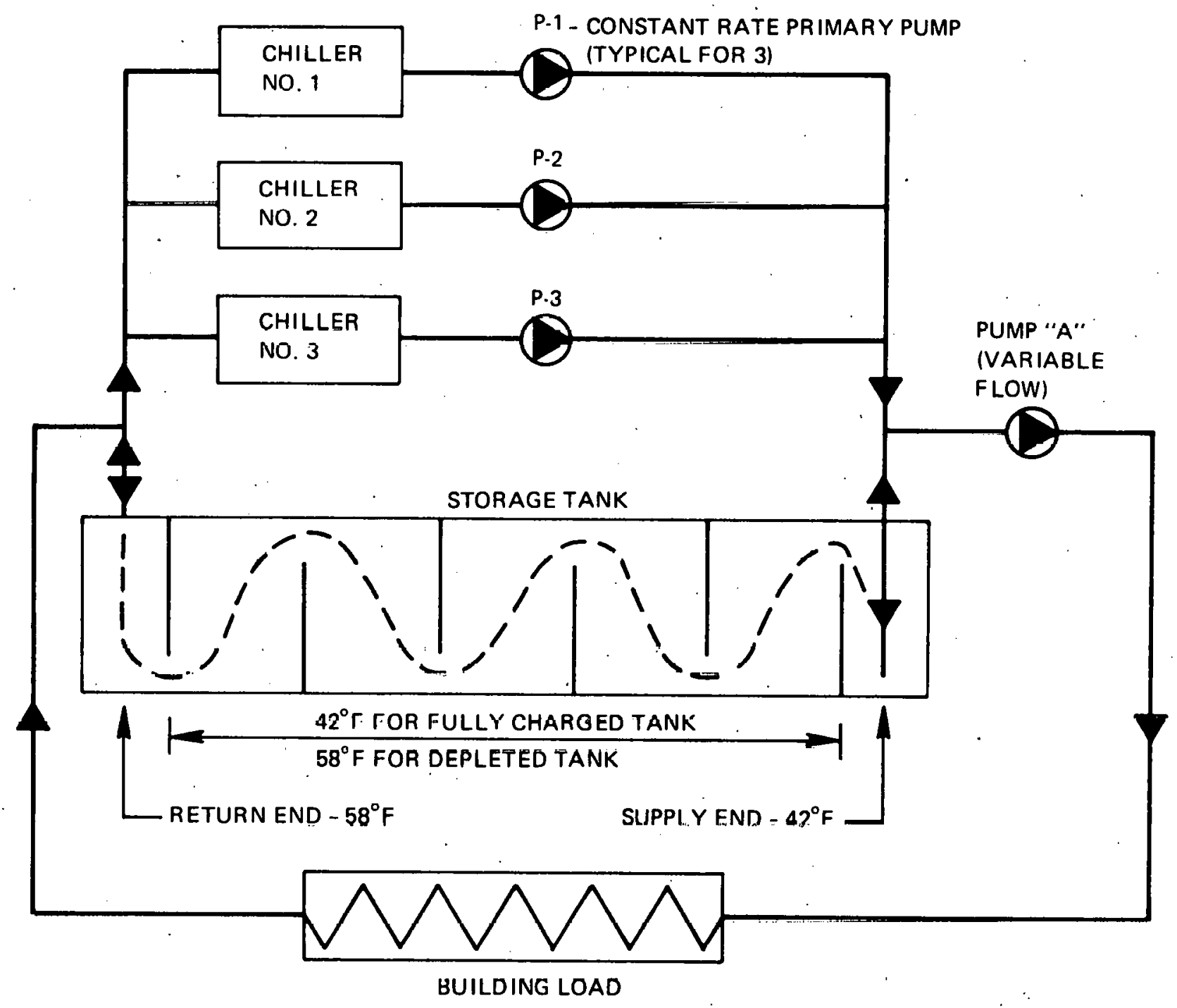

Figure V-8 REFRIGERATION MACHINE AND STORAGE TANK OPERATION 
from the AXCESS Computer program (Runs of May 12 through 16, 1976) are tabulated on the following pages. See Tables V-5 through V-8.

An analysis of the results indicated the following:

a. There is a substantial energy benefit obtained by introducing minimum thermal storage but a negligible energy benefit for increasing the amount of thermal storage to its maximum. (Comparison of Schemes 1 A thru 1E.)

b. As expected, the diesel schemes ranked highest in energy efficiency, the combustion turbine schemes next and the boiler/steam turbine schemes result in only a marginal energy savings over the standard central plant.

c. None of the schemes analyzed generated the annual electrical energy needs of the proposed development.

\section{Cyclic Flow of Building and Plant Outputs}

To illustrate the cyclic nature and flow of the building and plant thermal and electric outputs and net power flow in response to load and as effected by thermal storage tank sizes, graphs were prepared for weeks during spring, summer and fall operation, for selected schemes (runs).

a. A representative sample of these graphs for fall operation (November) are listed below and are included following this listing. These include:

$$
\begin{aligned}
& \text { Scheme 1A - Diesel Engine System (with absorption refrigera- } \\
& \text { tion) - with no thermal storage } \\
& \text { Scheme 1B - } \begin{array}{l}
\text { Diesel Engine System - with } 370,000 \mathrm{GAL} \\
\text { (minimum) chilled water thermal storage. }
\end{array} \\
& \text { Scheme 1E - Diesel Engine System - with 1,400,000 GAL } \\
& \text { (maximum) chilled water thermal storage. } \\
& \text { Scheme 2A - Combustion Turbine System (with steam turbine } \\
& \text { driven centrifugal refrigeration) - with } 370,000 \\
& \text { GAL (minimum) chilled water thermal storage. }
\end{aligned}
$$

$$
\begin{array}{r}
\text { Scheme 2D - Combustion Turbine System - with } 1,400,000 \\
\text { GAL (maximum) chilled water thermal storage. }
\end{array}
$$

b. The graphs for Scheme 1A, with no storage, illustrate the thermal and electric outputs in direct response to the building loads. The remaining graphs illustrate: that as the amount of cooling thermal storage is increased, the size of the refrigeration machines can be reduced to 


\section{GROUP 1 - DIESEL ENGINES, WASTE HEAT BOILERS, ABSORPTION \\ REFRIGERATION MACHINES \\ (ENER SY CONSUMP־ION OF TIES SYSTEMS STUDIED)}

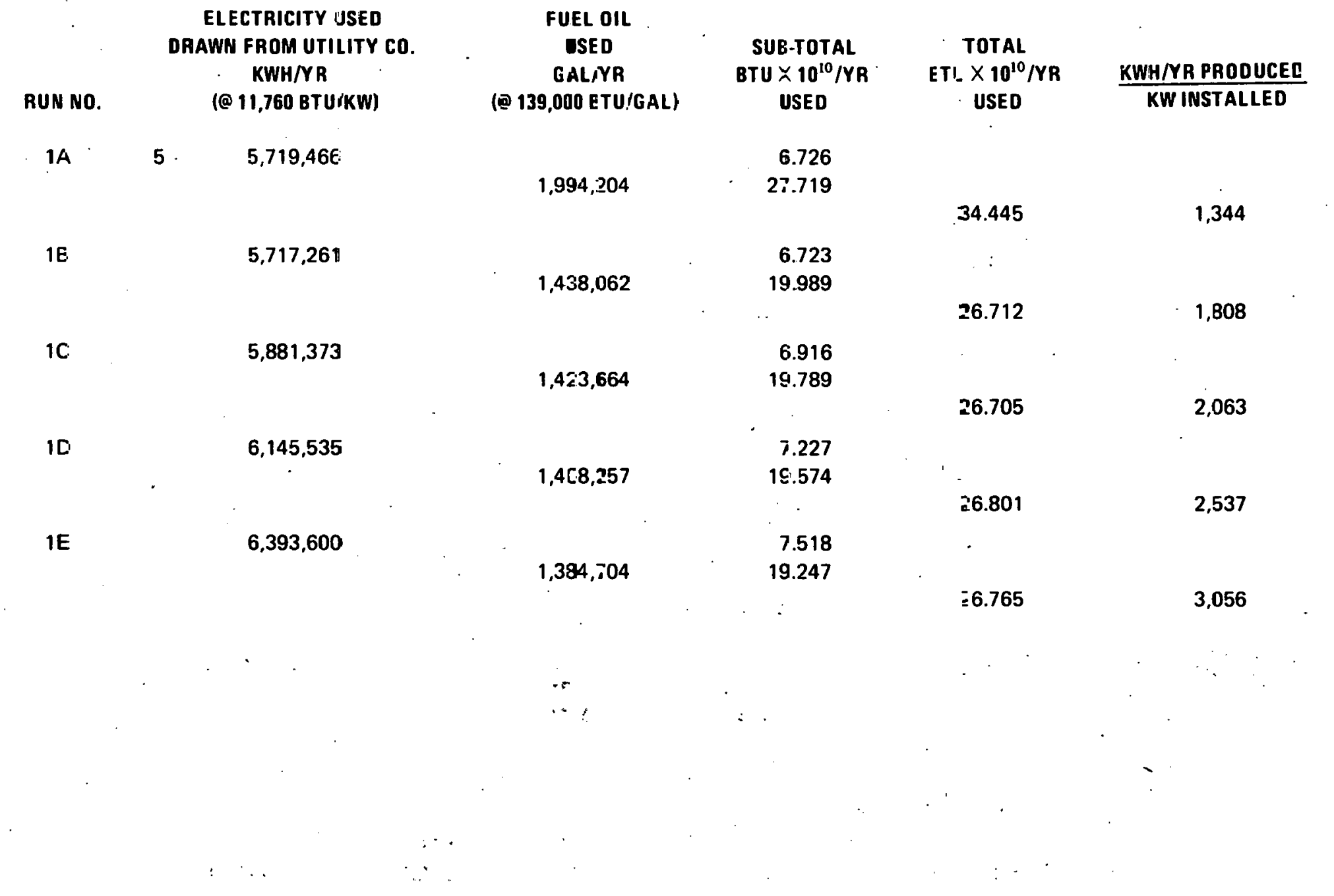


GROUP 2 - GAS TURBINES, WASTE HEAT BOILERS, CONDENSING STEAM TURBINES, CENTRIFUGAL REFRIGERATION MACHINES

(ENERGY CONSUMPTION OF TIES SYSTEMS STUDIED)

\begin{tabular}{|c|c|c|c|c|c|}
\hline RUN NO. & $\begin{array}{c}\text { ELECTRICITY USED } \\
\text { DRAWN FRDM UTILITY CO. } \\
\text { KWH/YR } \\
\text { (@ } 11,760 \mathrm{BTU} / \mathrm{KW})\end{array}$ & $\begin{array}{c}\text { FUEL OIL } \\
\text { USED } \\
\text { GAL/YR } \\
\text { (@ 139,000 BTU/GAL) }\end{array}$ & $\begin{array}{l}\text { SUB-TOTAL } \\
\text { BTU } \times 10^{10} / \mathrm{YA} \\
\text { USED }\end{array}$ & $\begin{array}{c}\text { TOTAL } \\
\text { BTU } \times 10^{10} / Y R \\
\text { USED }\end{array}$ & $\frac{\text { KWH/YR PRODUCED }}{\text { KW INSTALLED }}$ \\
\hline \multirow[t]{3}{*}{$2 A$} & $7,856,155$ & & 9.23 & & \\
\hline & & $1,852,484$ & 25.74 & & . \\
\hline & : & & & 34.98 & 2,008 \\
\hline \multirow[t]{3}{*}{$2 B$} & $8,168,519$ & & $9: 60$ & & \\
\hline & & $1,816,615$ & 25.20 & & \\
\hline & & & & 34.85 & 2,288 \\
\hline \multirow[t]{3}{*}{$2 C$} & $8,378,540$ & & 9.85 & & \\
\hline & & $1,761,836$ & 24.40 & & \\
\hline & & & & 34.34 & 2,866 \\
\hline \multirow[t]{3}{*}{ 2D } & $8,871,855$ & & 10.43 & & \\
\hline & & $1,691,207$ & 23.50 & & \\
\hline & & & & 33.93 & 3,480 \\
\hline
\end{tabular}


GROUP 3 - STEAM BOILERS, BACK PRESSURE STEAMI TURBINES,

ABSORPTION REFRIGERATION MACHINES

(ENERGY.CONSUMPTION OF TIES SYSTEMS STUDIED)

\begin{tabular}{|c|c|c|c|c|c|}
\hline RUN NO. & $\begin{array}{c}\text { ELECTRICITY USED } \\
\text { DRATTN FROM UTTLITY CO. } \\
\text { KWH/YR } \\
\text { (@ } 11,760 \mathrm{BTU} / \mathrm{KW})\end{array}$ & $\begin{array}{c}\text { FUEL OIL } \\
\text { USED } \\
\text { GAL/YR } \\
\text { (@ 139,000 BTU/GAL) }\end{array}$ & $\begin{array}{c}\text { SUB.TOTAL } \\
\text { BTU } \times 11^{10} / Y R \\
\text { USED }\end{array}$ & $\begin{array}{c}\text { TOTAL } \\
\text { BTLE } \times 10^{10} / \mathrm{VR} \\
\text { USED }\end{array}$ & $\frac{\text { KWH/YR PRODUCED }}{\text { KW IMSTALLED }}$ \\
\hline \multirow[t]{3}{*}{$3 A$} & $22,069,572$ & & 25.95 & & \\
\hline & & 794,242 & 11.04 & & \\
\hline & & & & 36.99 & 1,808 \\
\hline \multirow[t]{3}{*}{38} & $21,995,764$ & & 25.87 & & \\
\hline & & 785,585 & 10.92 & & \\
\hline & & & & 36.79 & 2,062 \\
\hline \multirow[t]{3}{*}{$3 \mathrm{C}$} & $22,062,068$ & & 25.94 & & \\
\hline & & $776, \bar{i} 20$ & 10.80 & & \\
\hline & & & & 35.74 & 2,537 \\
\hline \multirow[t]{3}{*}{ 3D } & $22,074,067$ & & 25.96 & & \\
\hline & & $764, E: 18$ & 10.63 & & \\
\hline & & & & ¿̄o.59 & 3,053 \\
\hline
\end{tabular}


GROUP 4 - GAS TURBINES, WASTE HEAT BOILERS, BACK PRESSURE STEAM TURBINES, ABSORPTION REFRIGERATION MACHINES

(ENERGY CONSUMPTION OF TIES SYSTEMS STUDIED)

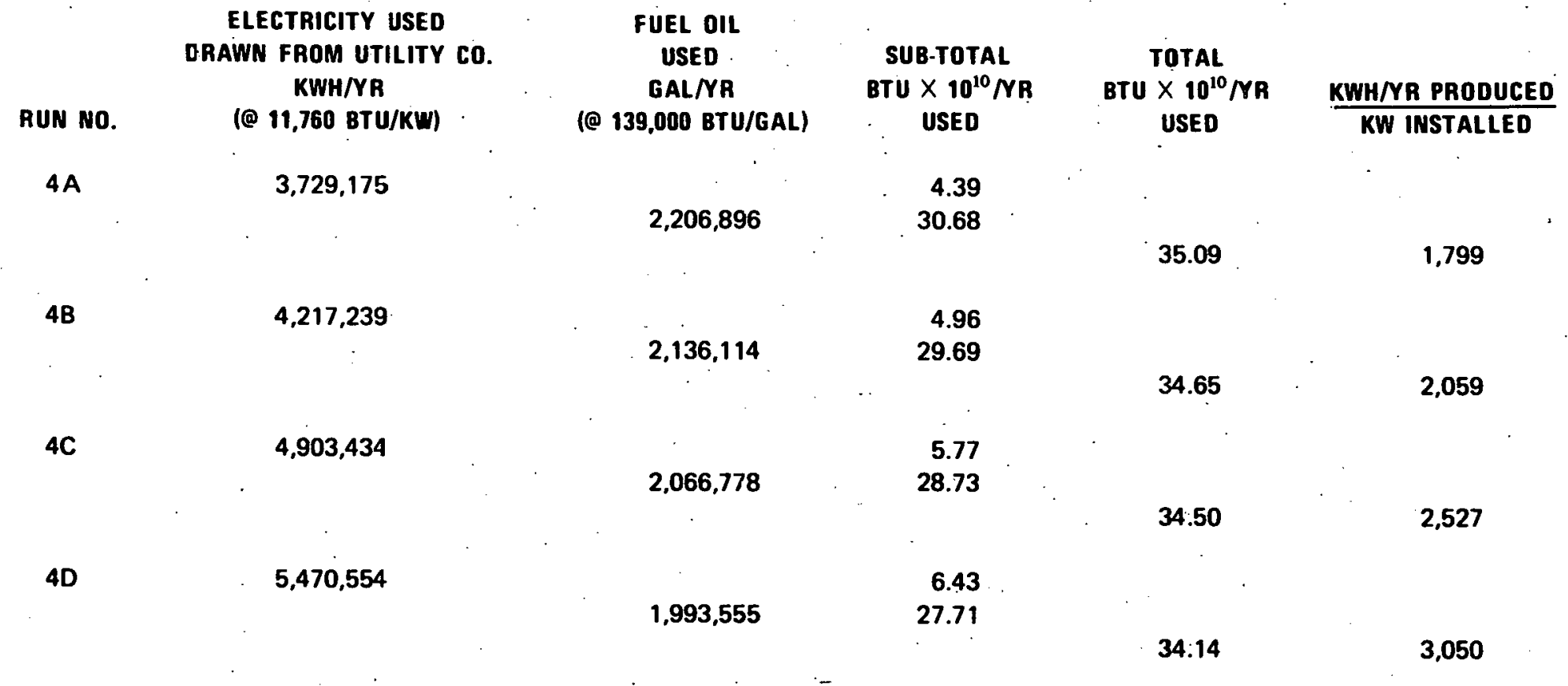


produce the same ton-hours per day; and that simultaneously less waste heat is rejected to the heating thermal storage tanks, requiring smaller tanks with less heating thermal storage; and that simultaneously the plant electrical power output decreases while the net electricity drawn from the power company grid increases.

\begin{tabular}{|c|c|c|c|}
\hline FIG. NO: & MONTH & SCHEME & TITLE \\
\hline$V \cdot 9$ & Nov. & $1 \mathrm{~A}$ & Plant Power Output \\
\hline$V-10$ & Nov. & $1 \mathrm{~A}$ & Net Grid Output \\
\hline$V-11$ & Nov. & $1 \mathrm{~A}$ & Plant Cooling Output \\
\hline$V-12$ & Nov. & $1 \mathrm{~A}$ & Plant Heating Output \\
\hline$V-13$ & Nov. & $1 B$ & Plant Power Output \\
\hline V-14. & Nov. & $1 B$ & Net Grid Output \\
\hline$V-15$ & Nov. - & $1 B$ & Plant Cooling Output \\
\hline$V-16$ & Nov. & $1 B$ & Plant Heating Output \\
\hline$v-17$ & Nov. & IE & Plant Power Output \\
\hline$V-18$ & Nov. & $1 E$ & Net Grid Output \\
\hline$V-19$ & Nov. & $1 E$ & Plant Cooling Output \\
\hline$V \cdot 20$ & Nov. & $1 E$ & Plant Heating Output \\
\hline$V-21$ & Nov. & $2 A$ & Plant Power Output \\
\hline$V-22$ & Nov. & $2 A$ & Net Grid Output \\
\hline$V-23$ & Nov. & $2 A$ & Plant Cooling Output \\
\hline$V-24$ & Nov. & $2 A$ & Plant Heating Output \\
\hline$V-25$ & Nov. & $2 \mathrm{D}$ & Plant Power Output \\
\hline V-26 & Nov. & $2 D$ & Net Grid Output \\
\hline V-27 & Nov. & $2 \mathrm{D}$ & Plant Cooling Output \\
\hline$V-28$ & Nov: & 20 & Plant Heating Output \\
\hline
\end{tabular}

D. ANNUAL COSTS OF TIES SYSTEMS

1. Capital Costs

The data for capital costs for the TIES plant, for the various schemes, was developed as follows:

d. The cost of the plant structure was estimated by the cost estimating and scheduling consultants for Pasadena Redevelopment Agency. This wuuld be the cost of the space or portion of structure occupied by the TIFS Plant which was assumed to be located in ilie luwer level of Parking Structure, Parcel ' $\mathrm{H}$ ', adjacent to the retail center. This cost also included the underground thermal storage tanks.

b. To these costs were added the costs of site utilities to serve the TIES

Plant, also obtained from the community cost consultants.

c. Plus the costs for mechanical and electrical work. 


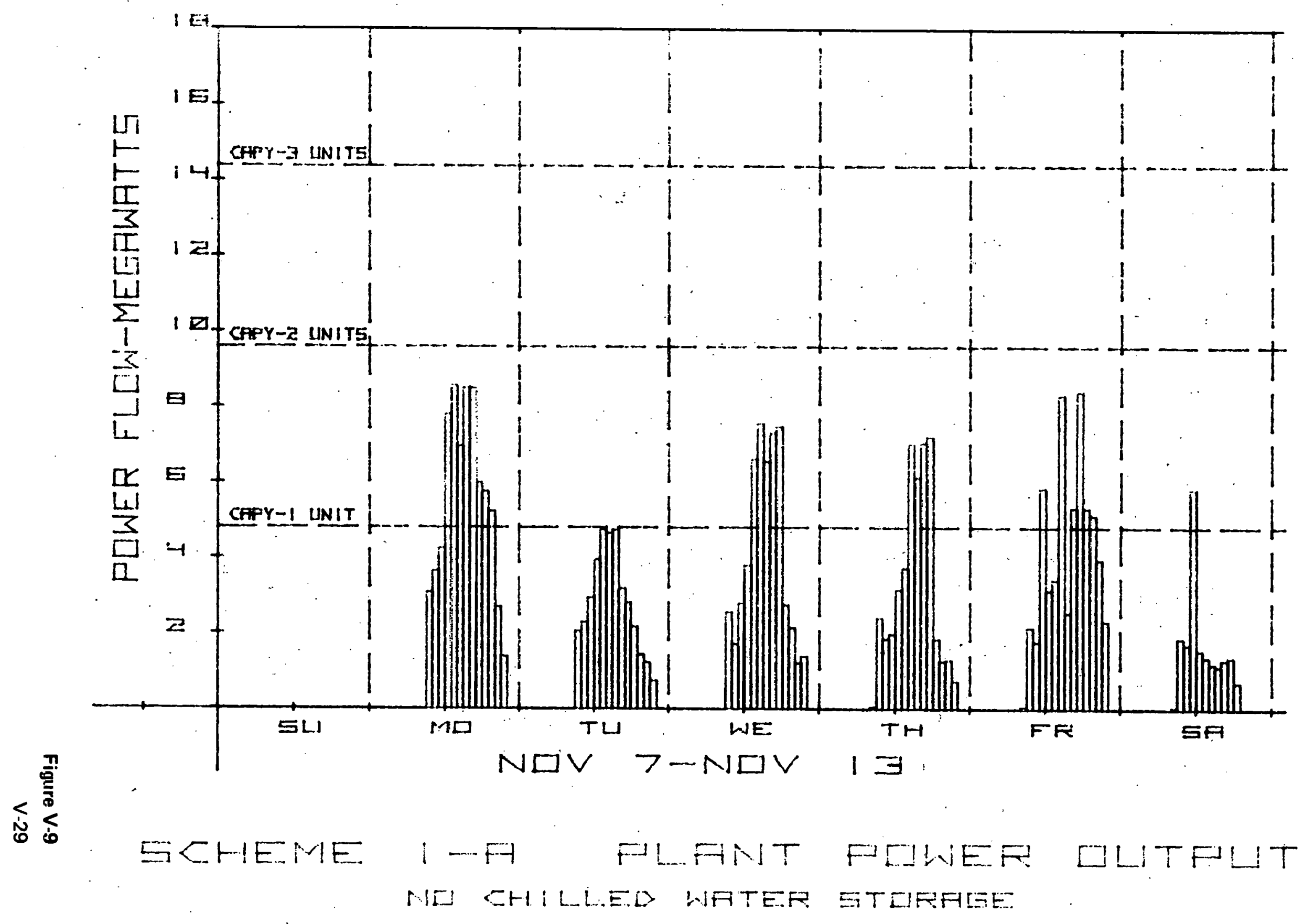




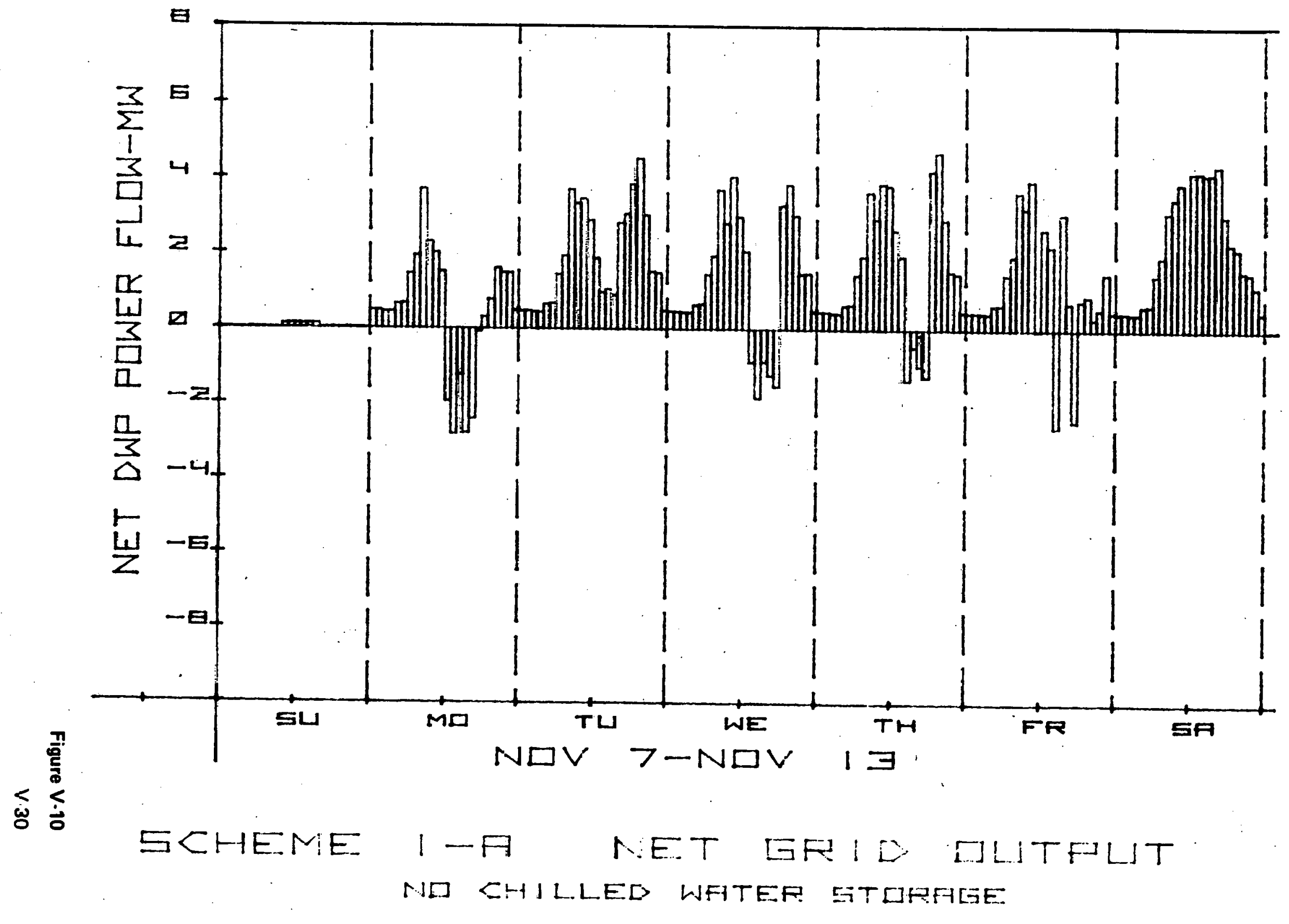




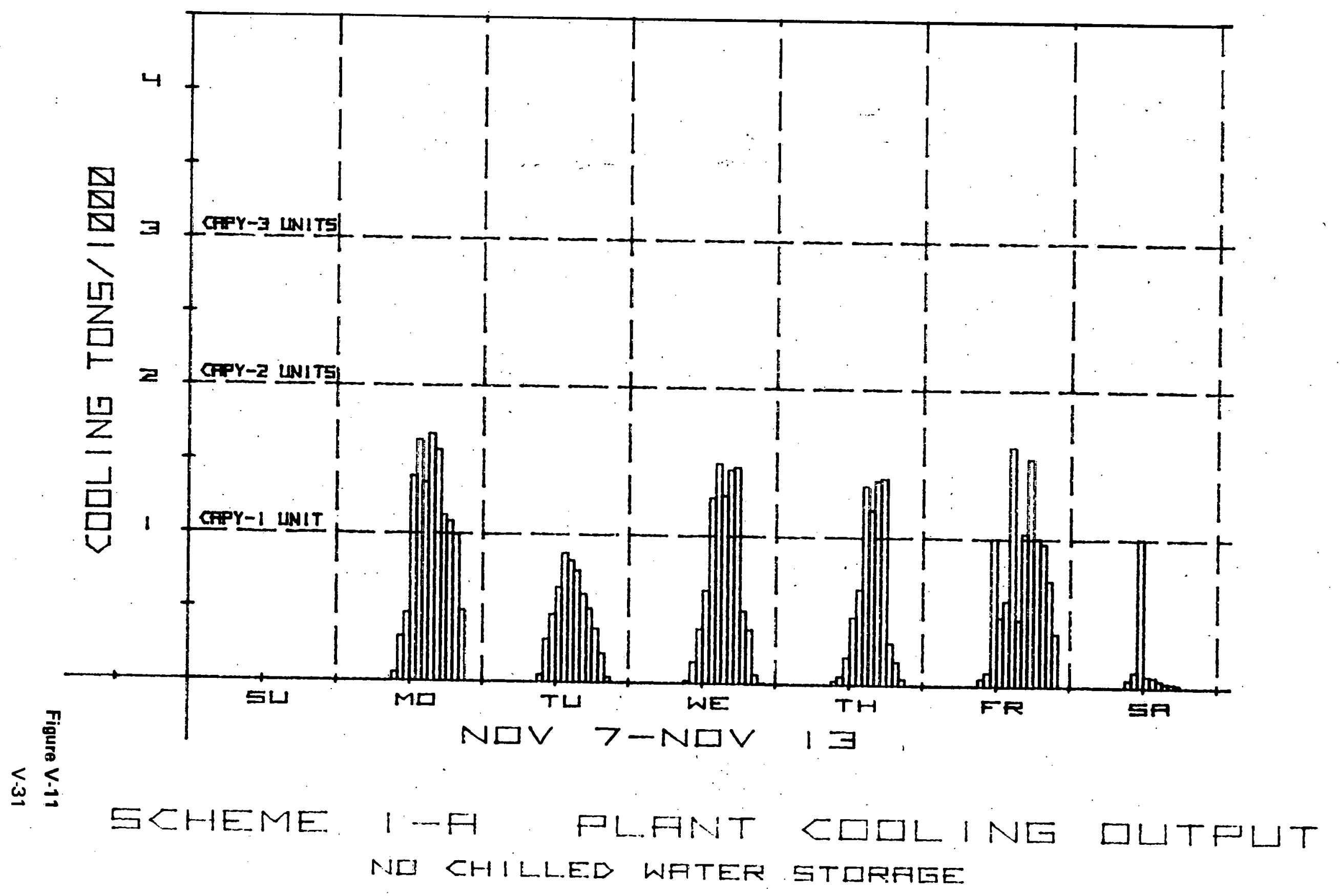


WWWW 


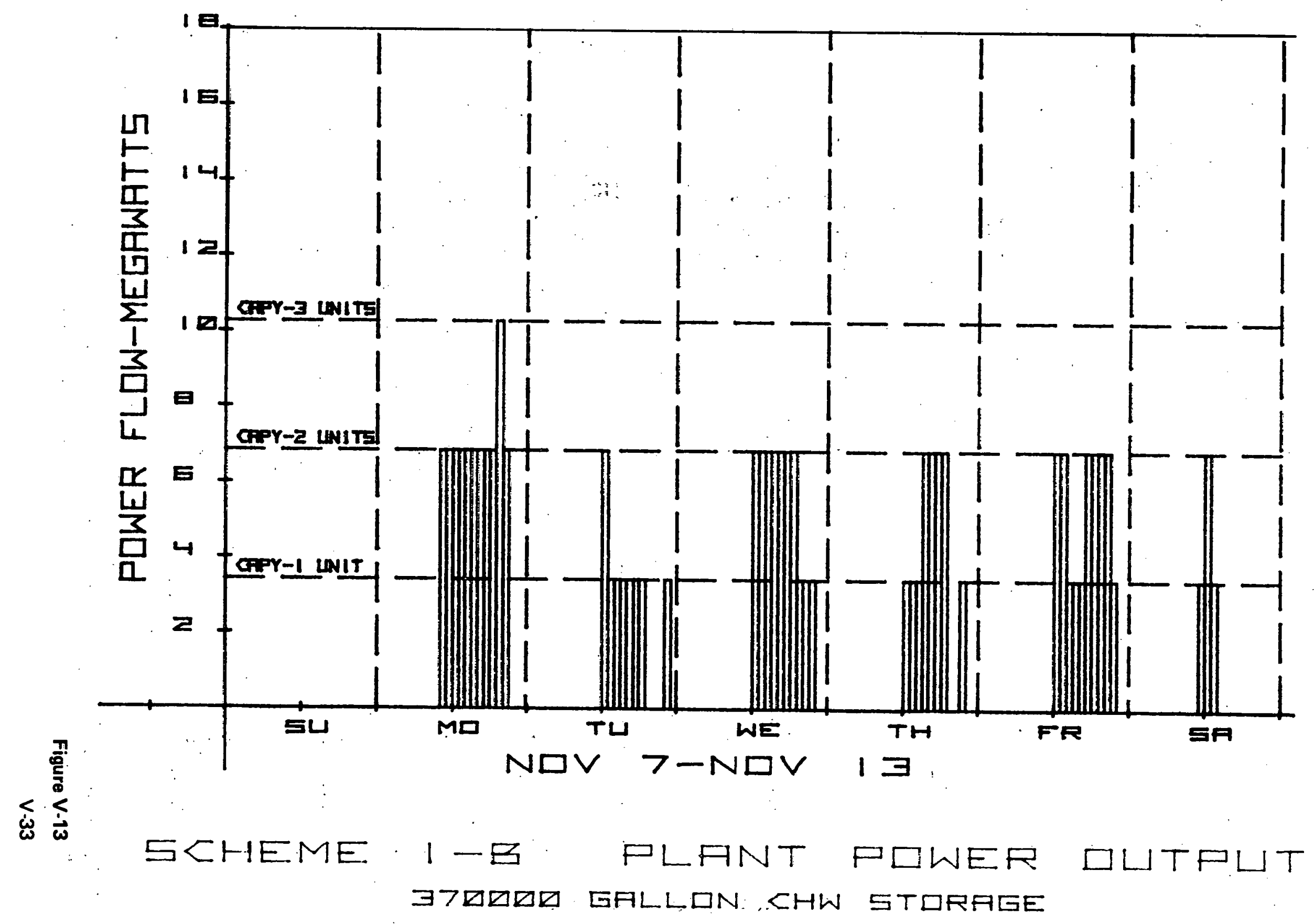




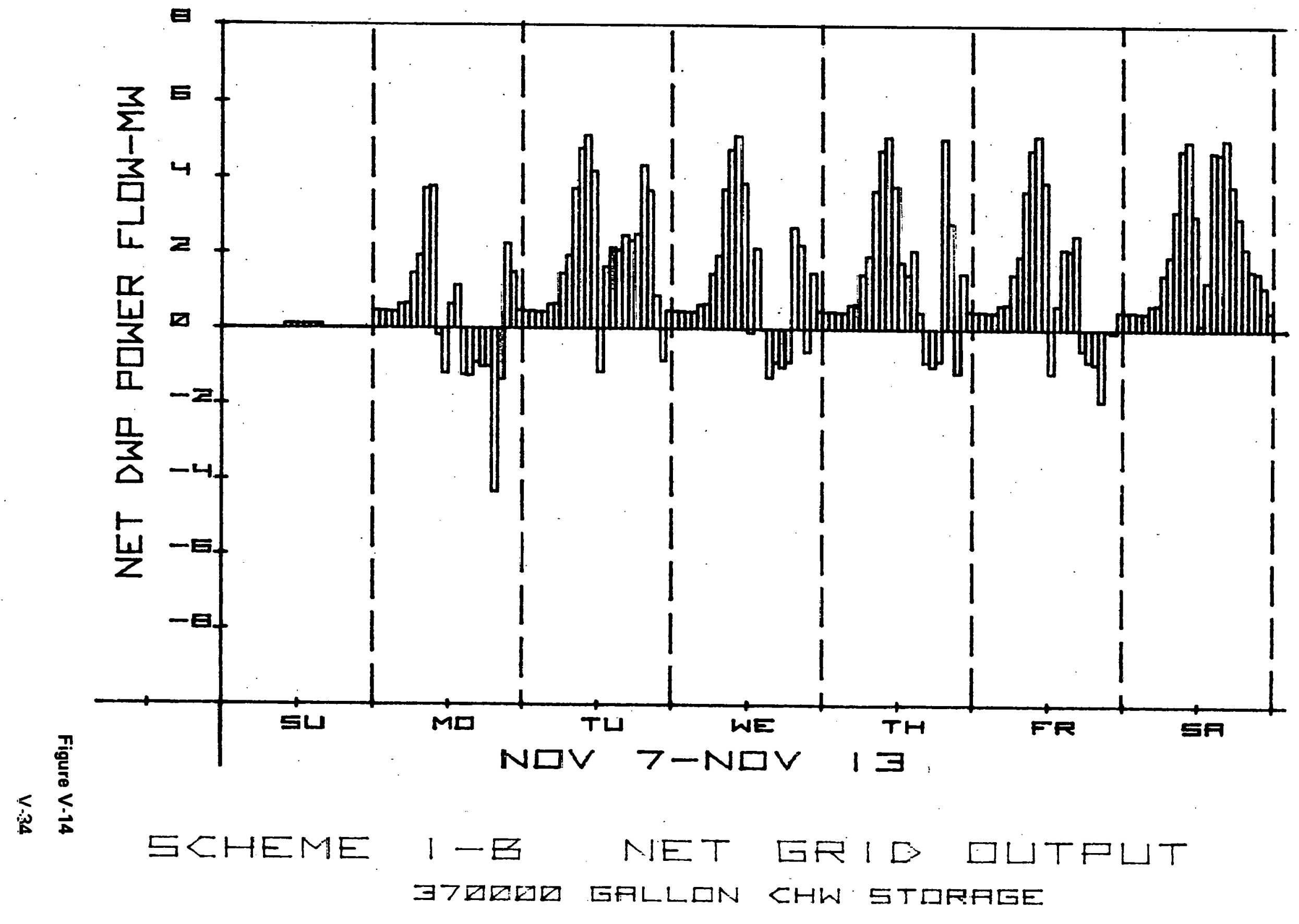




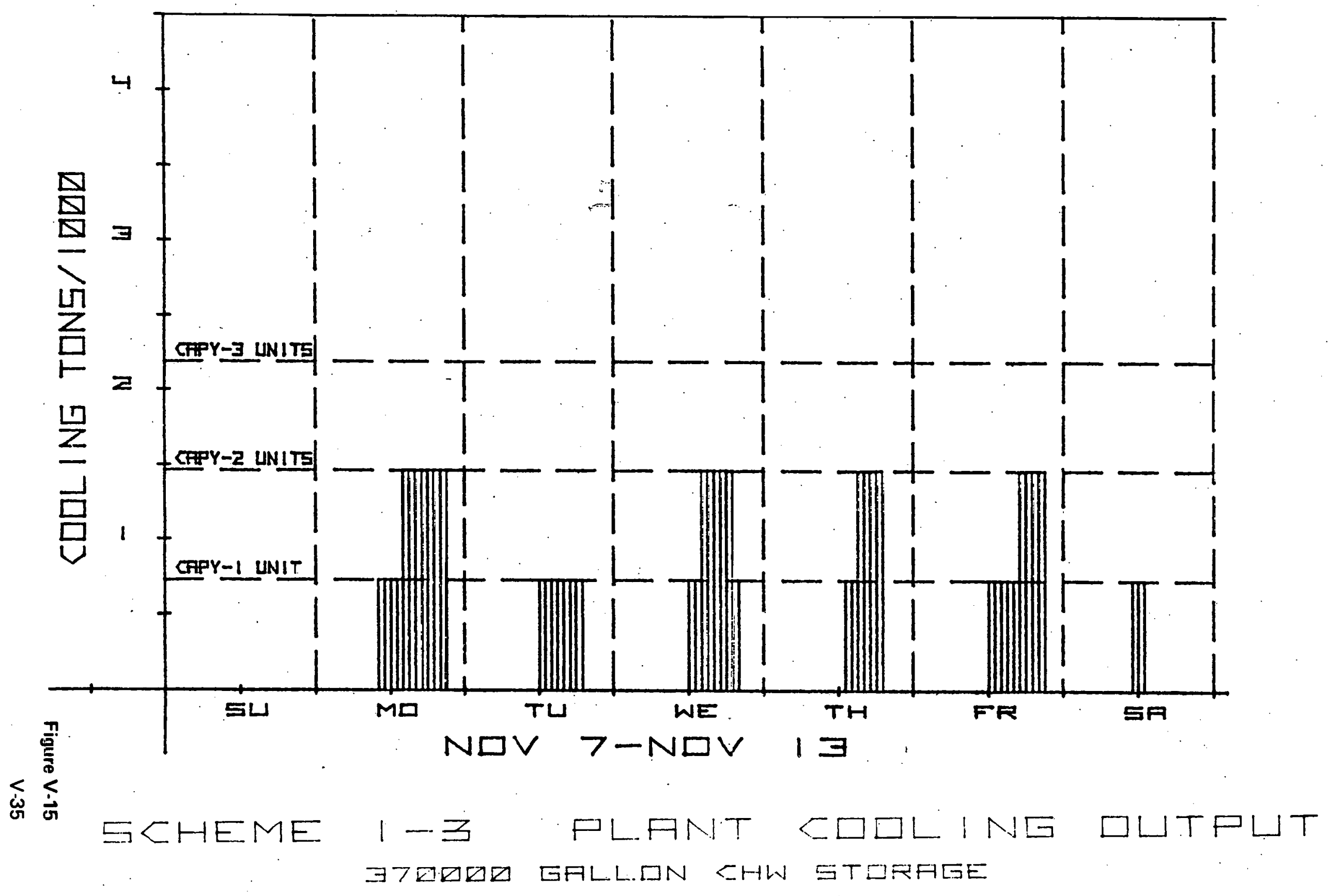




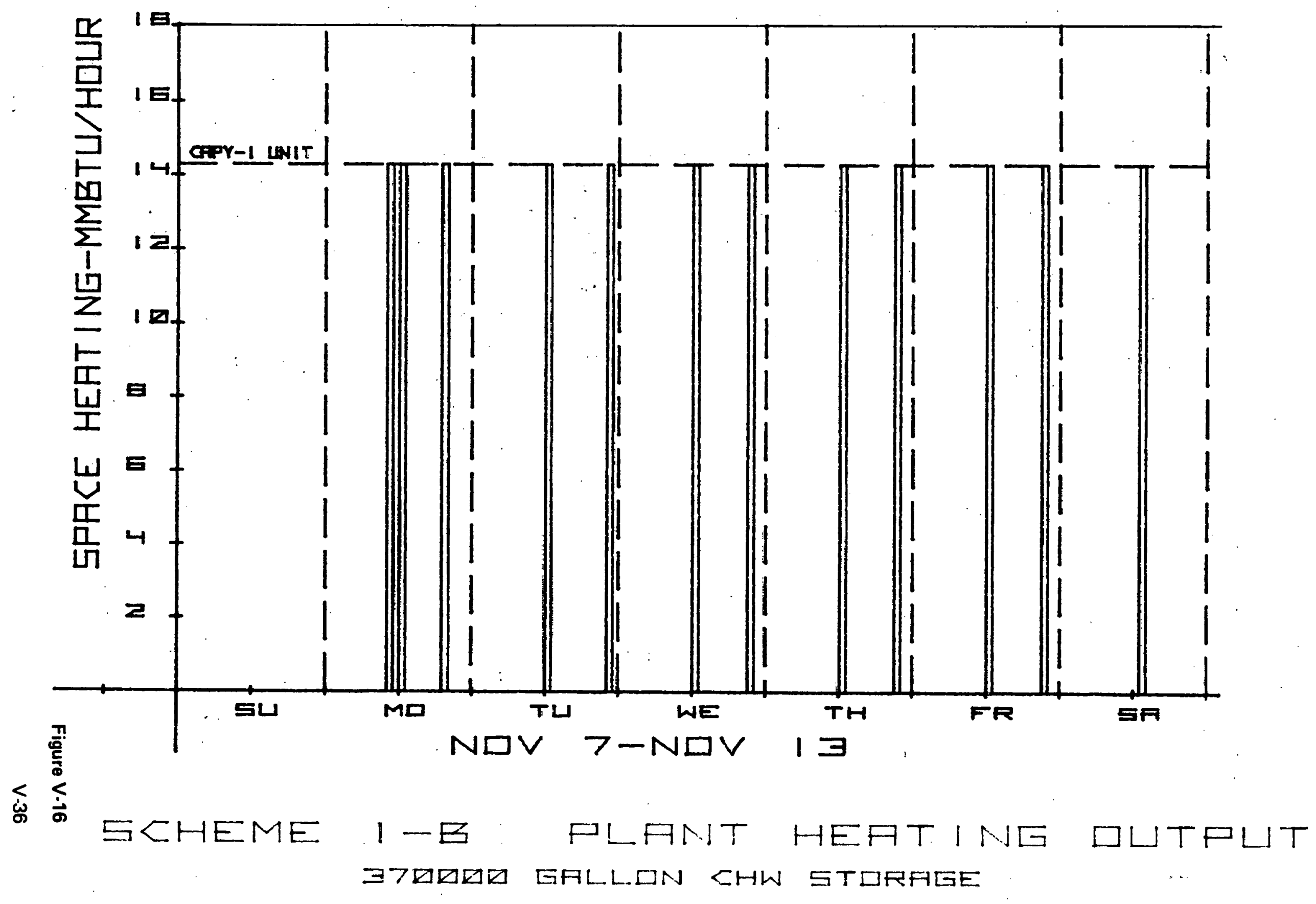




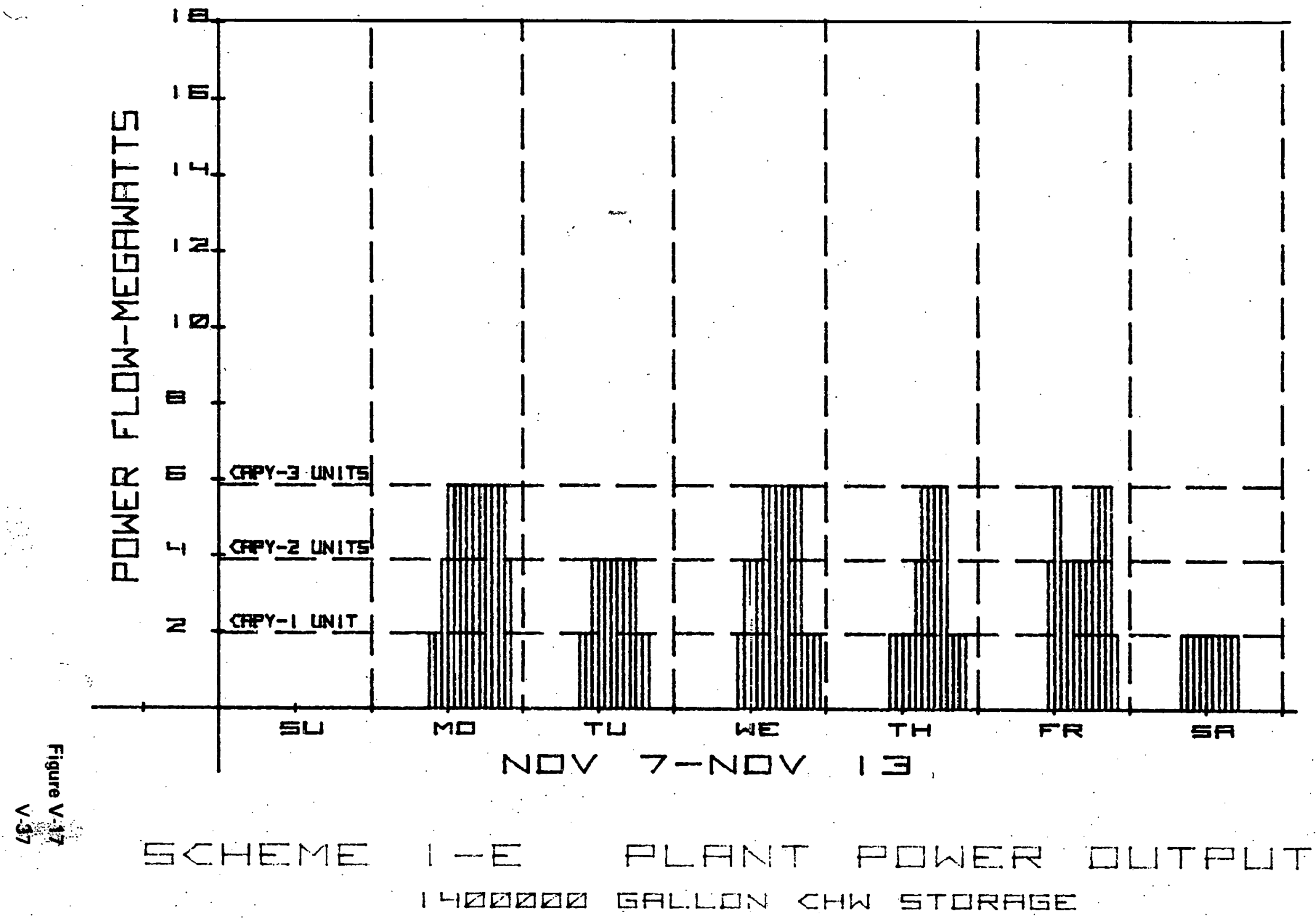




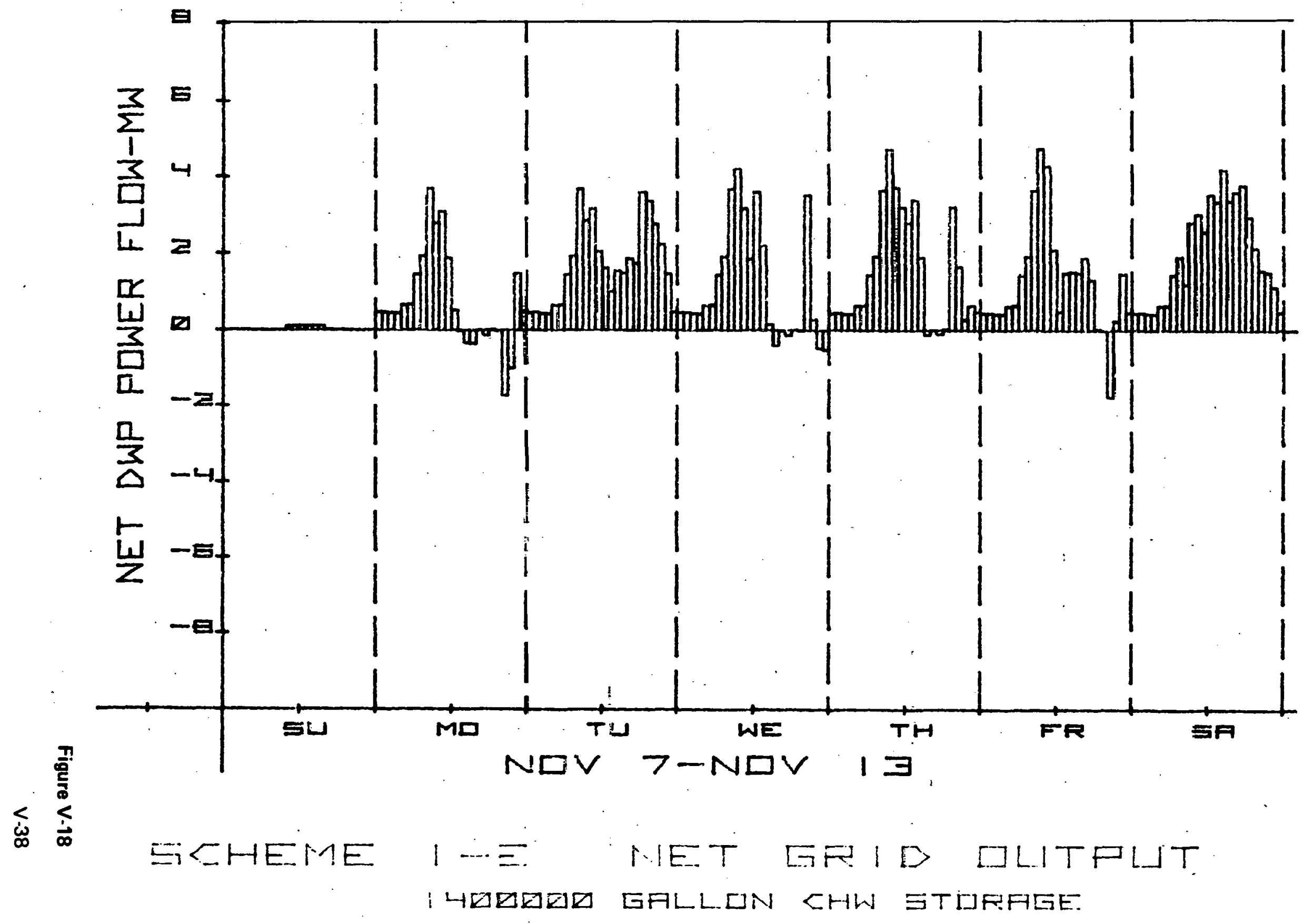




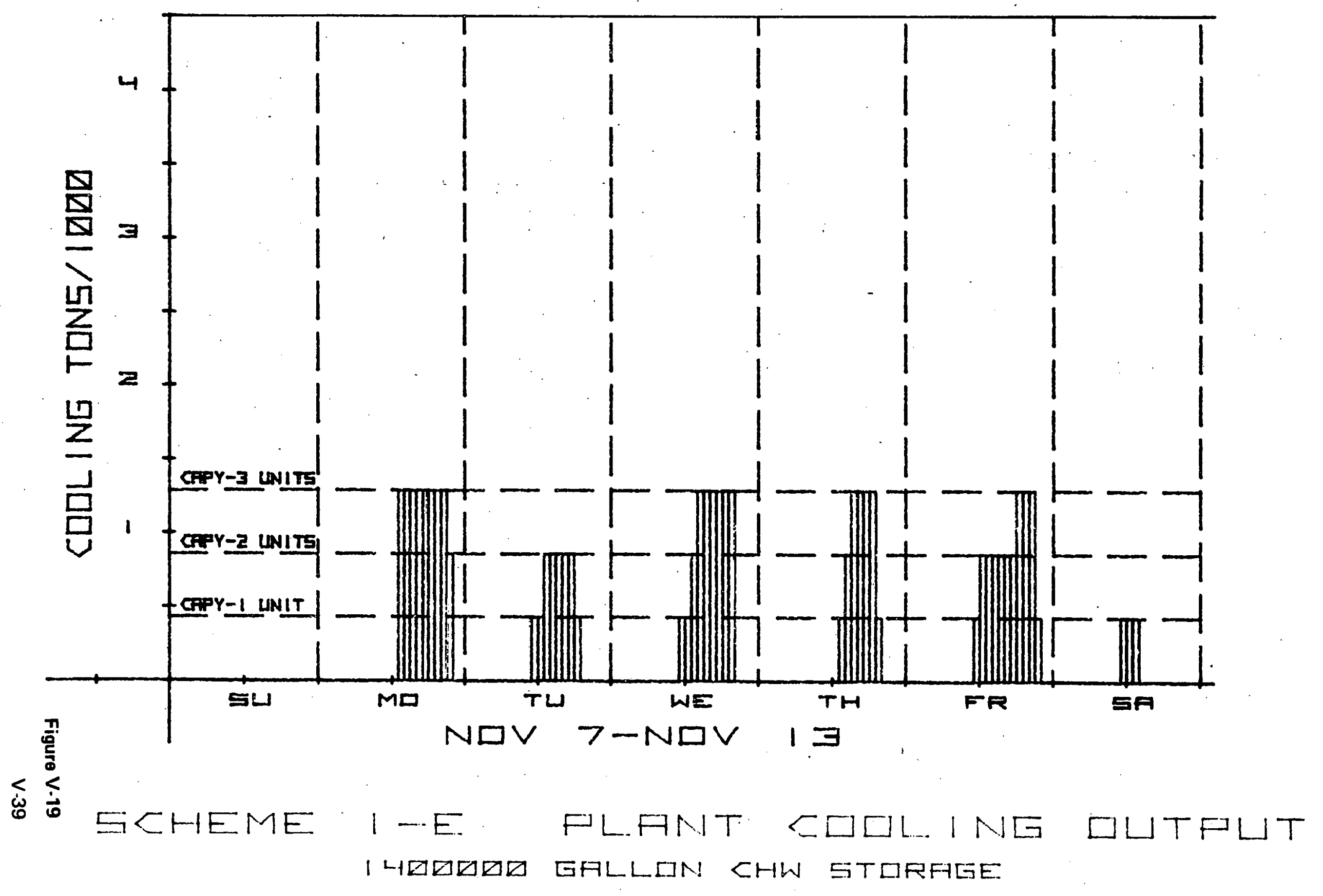




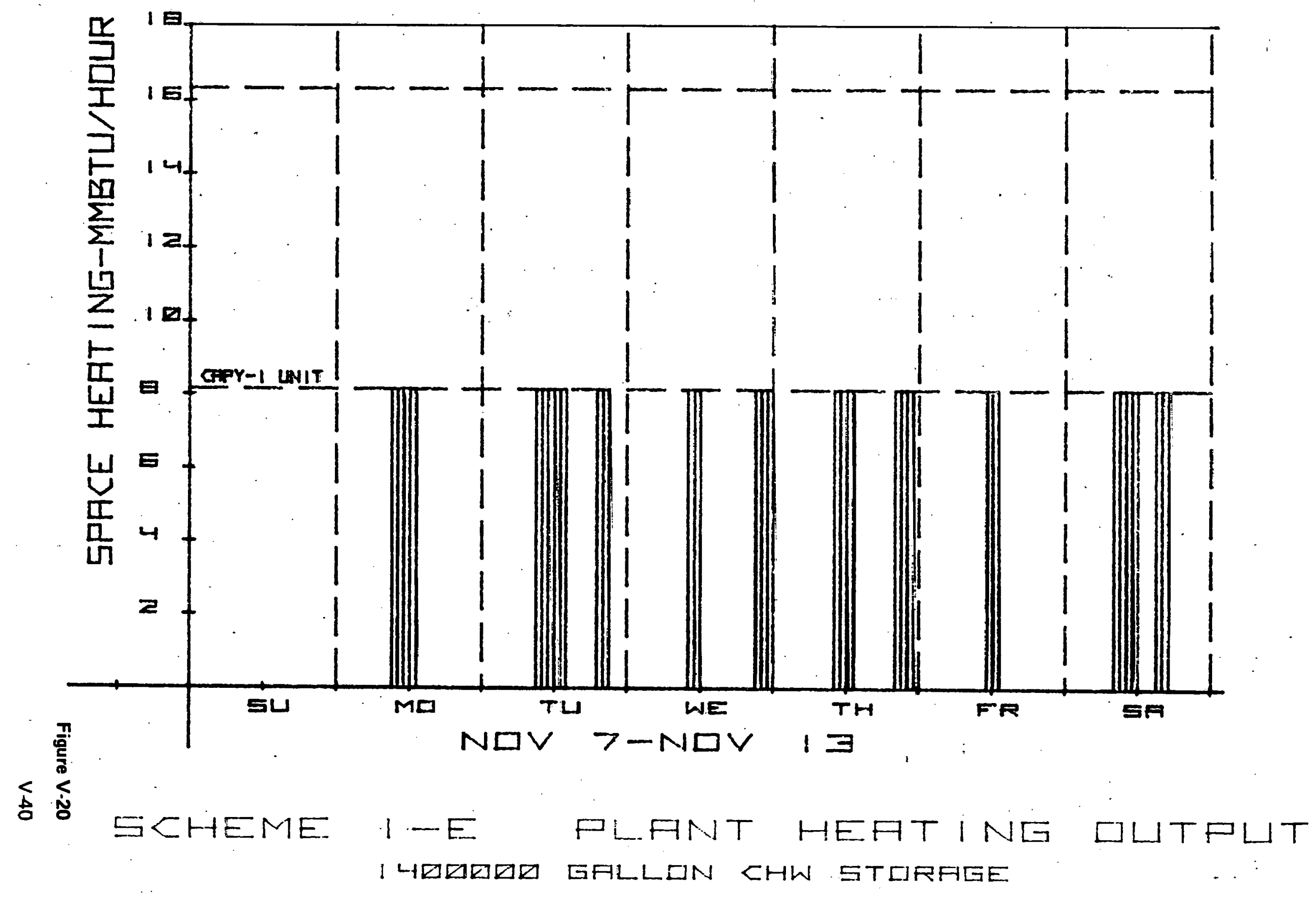




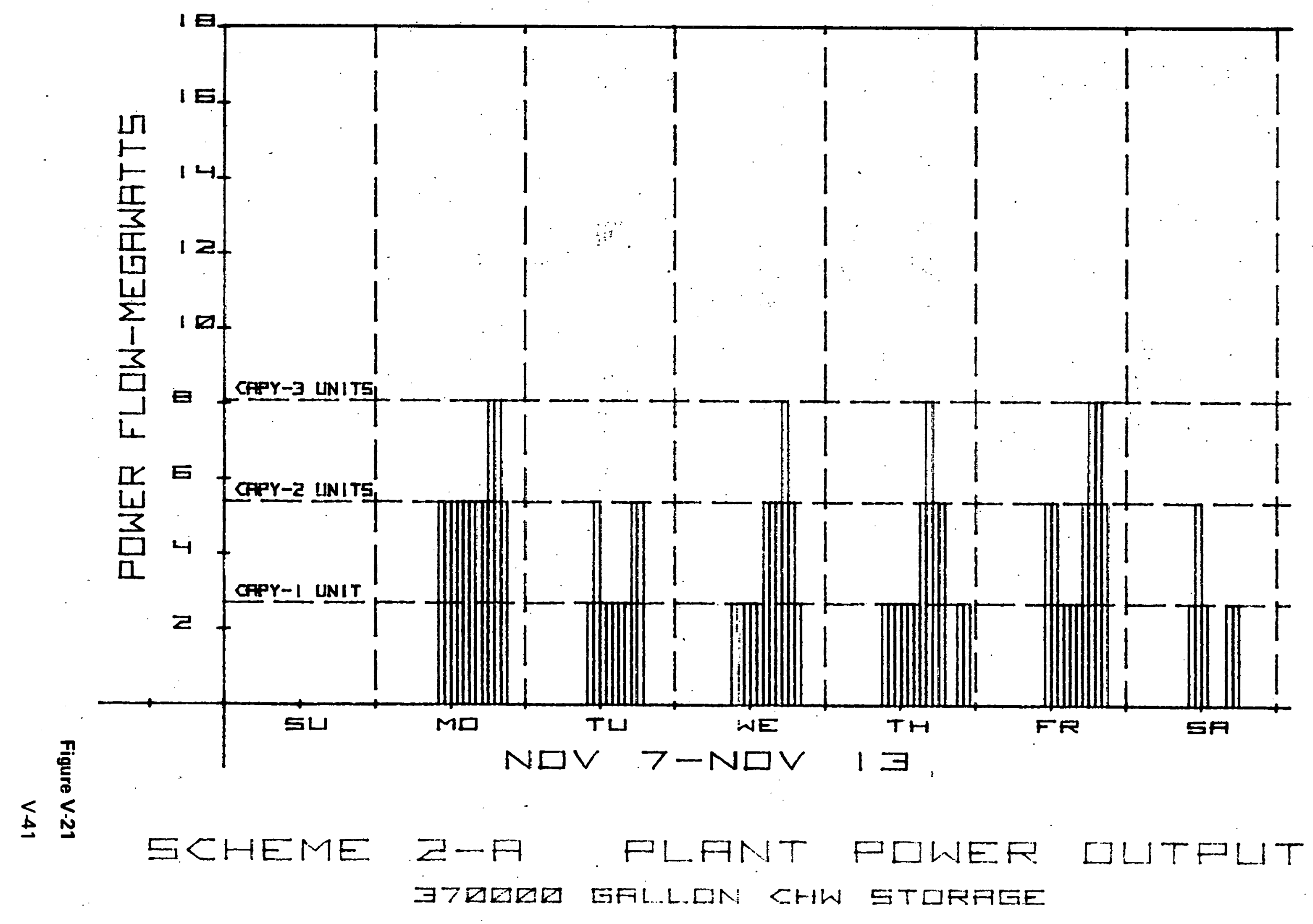




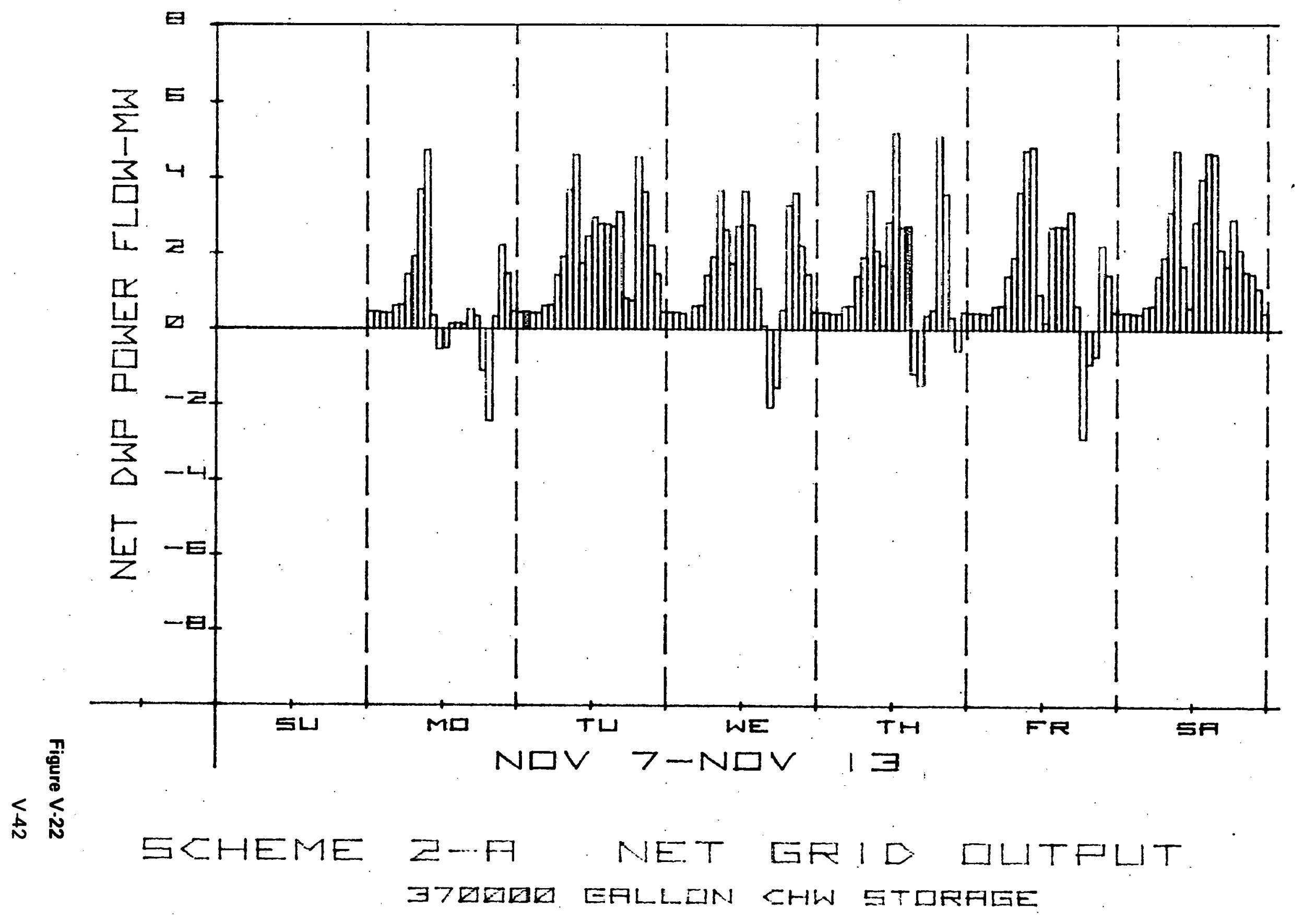




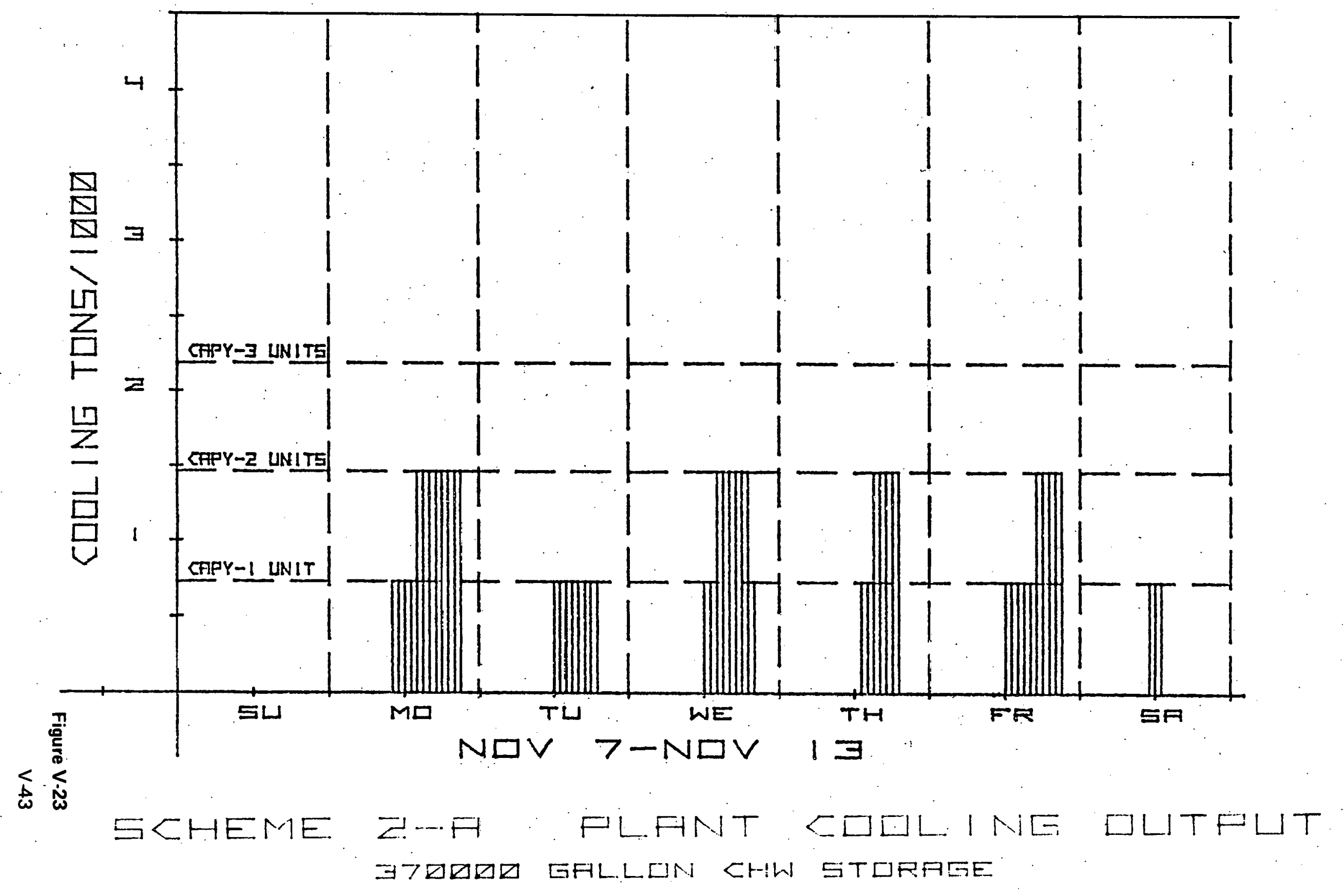




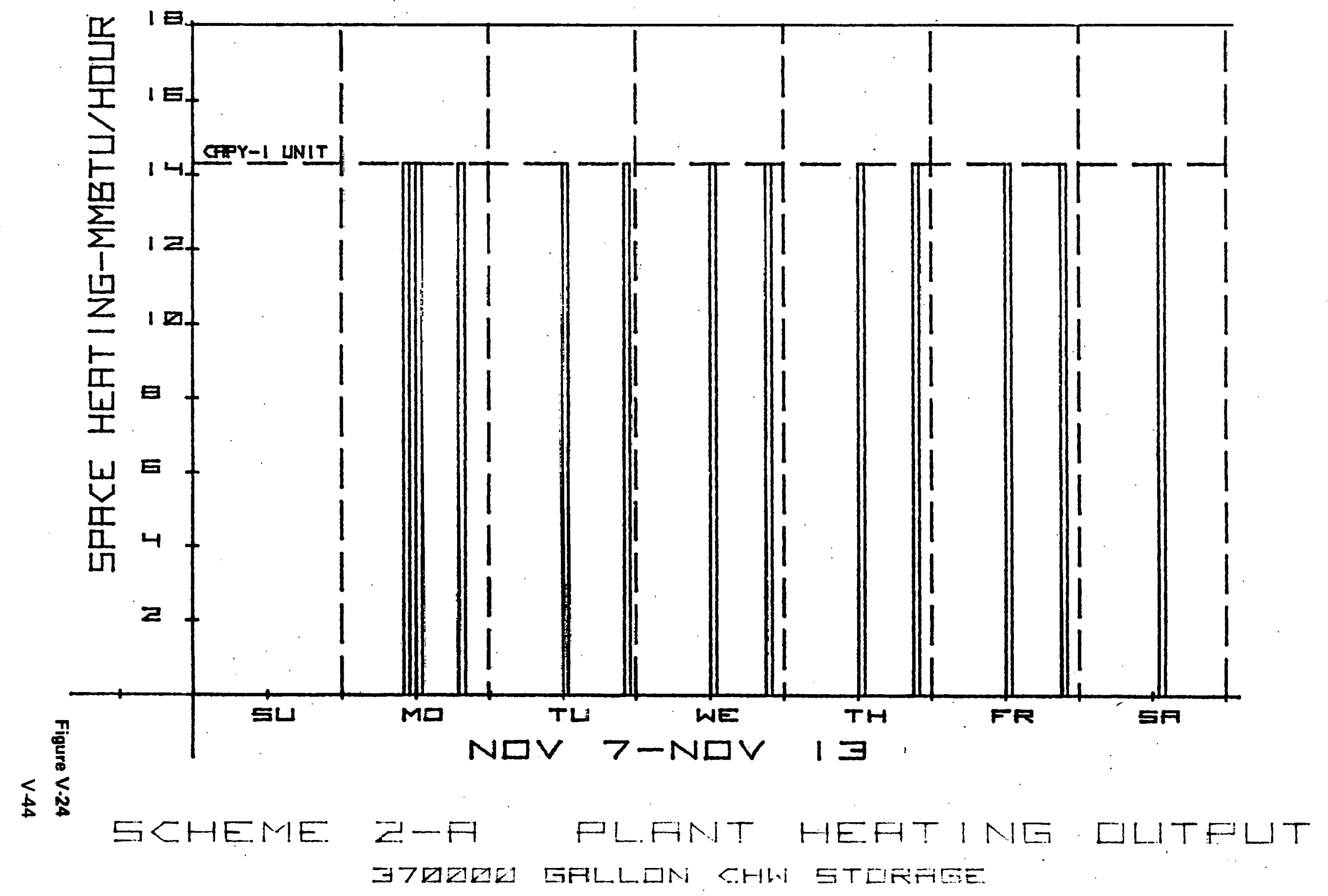




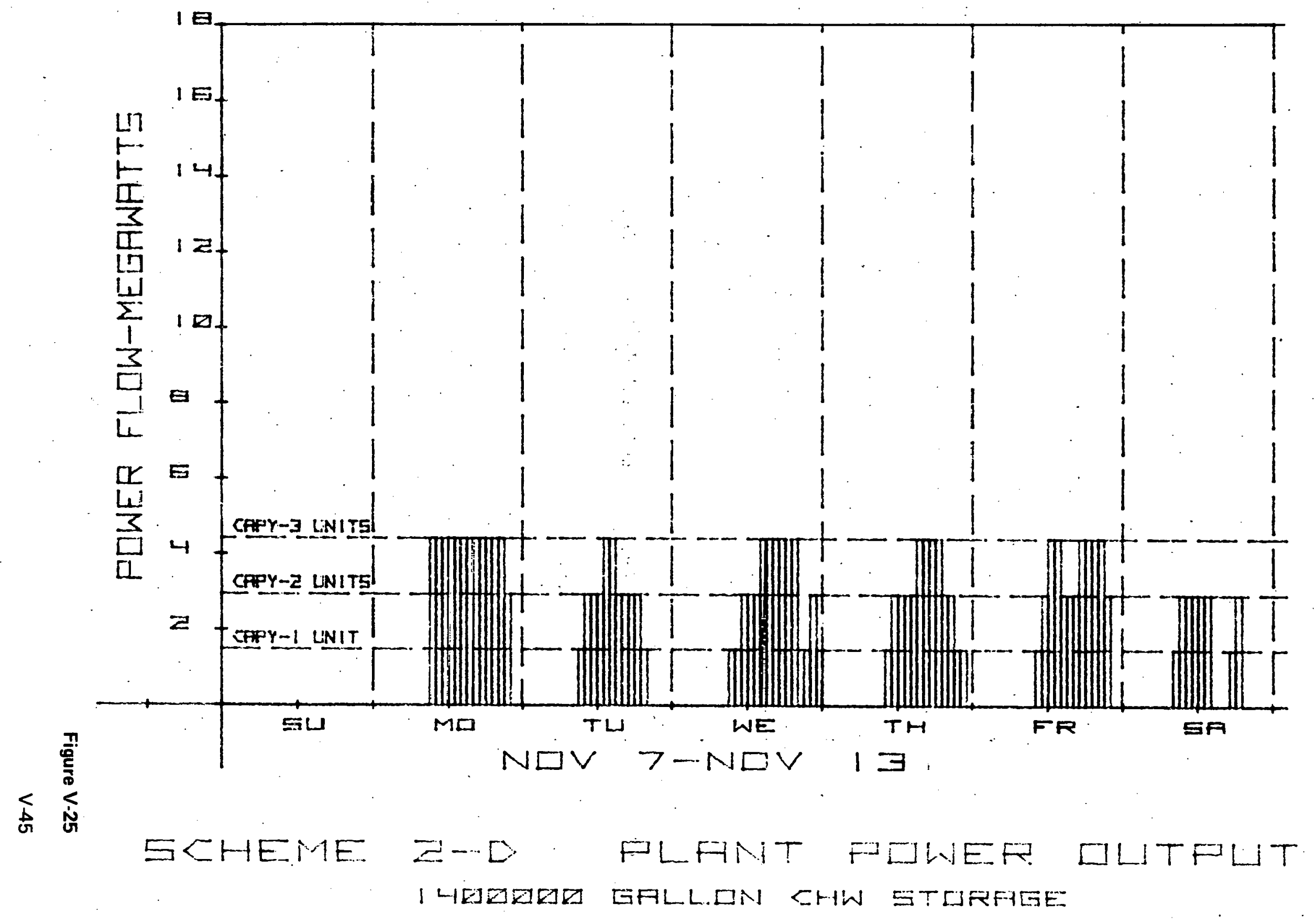




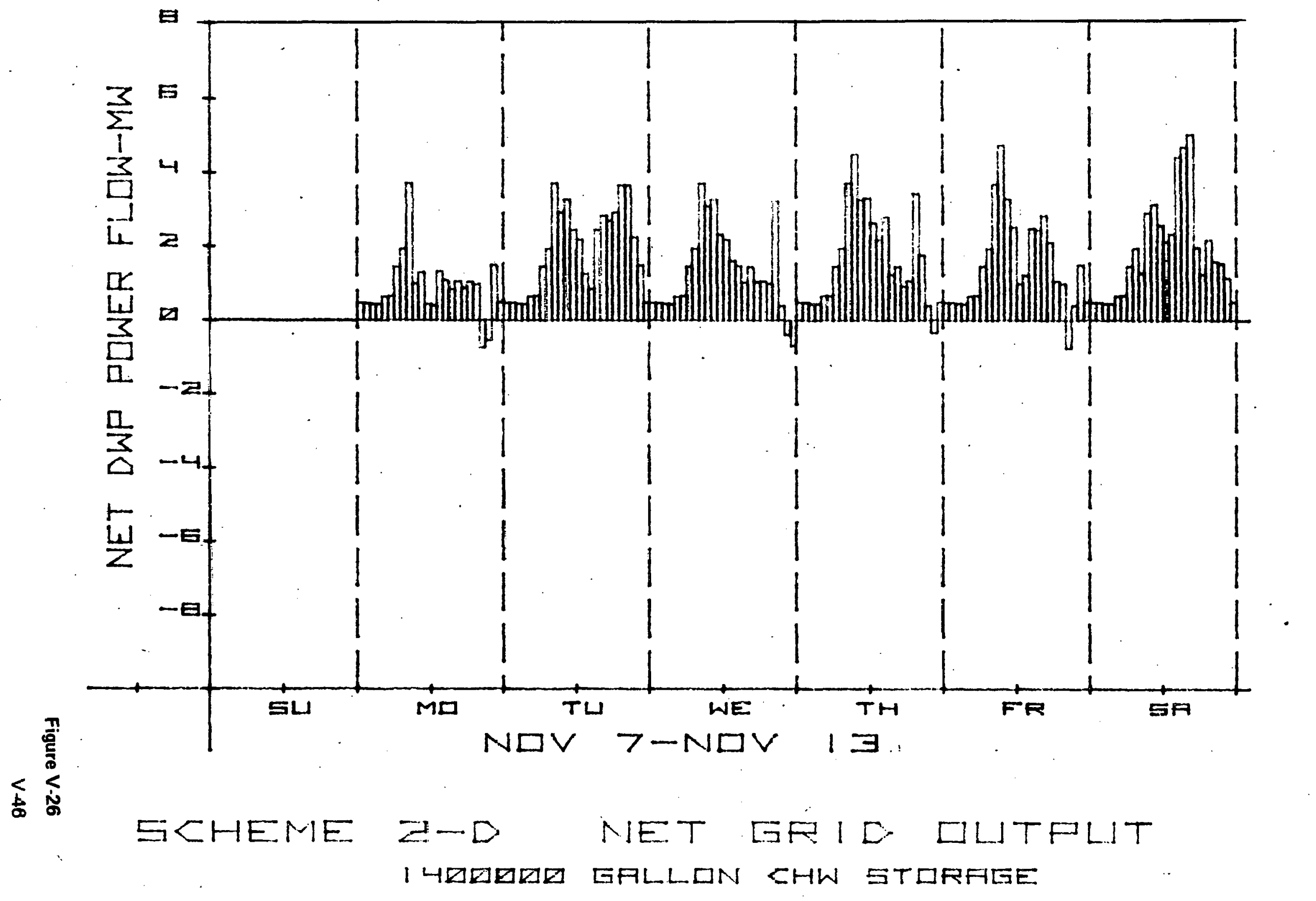




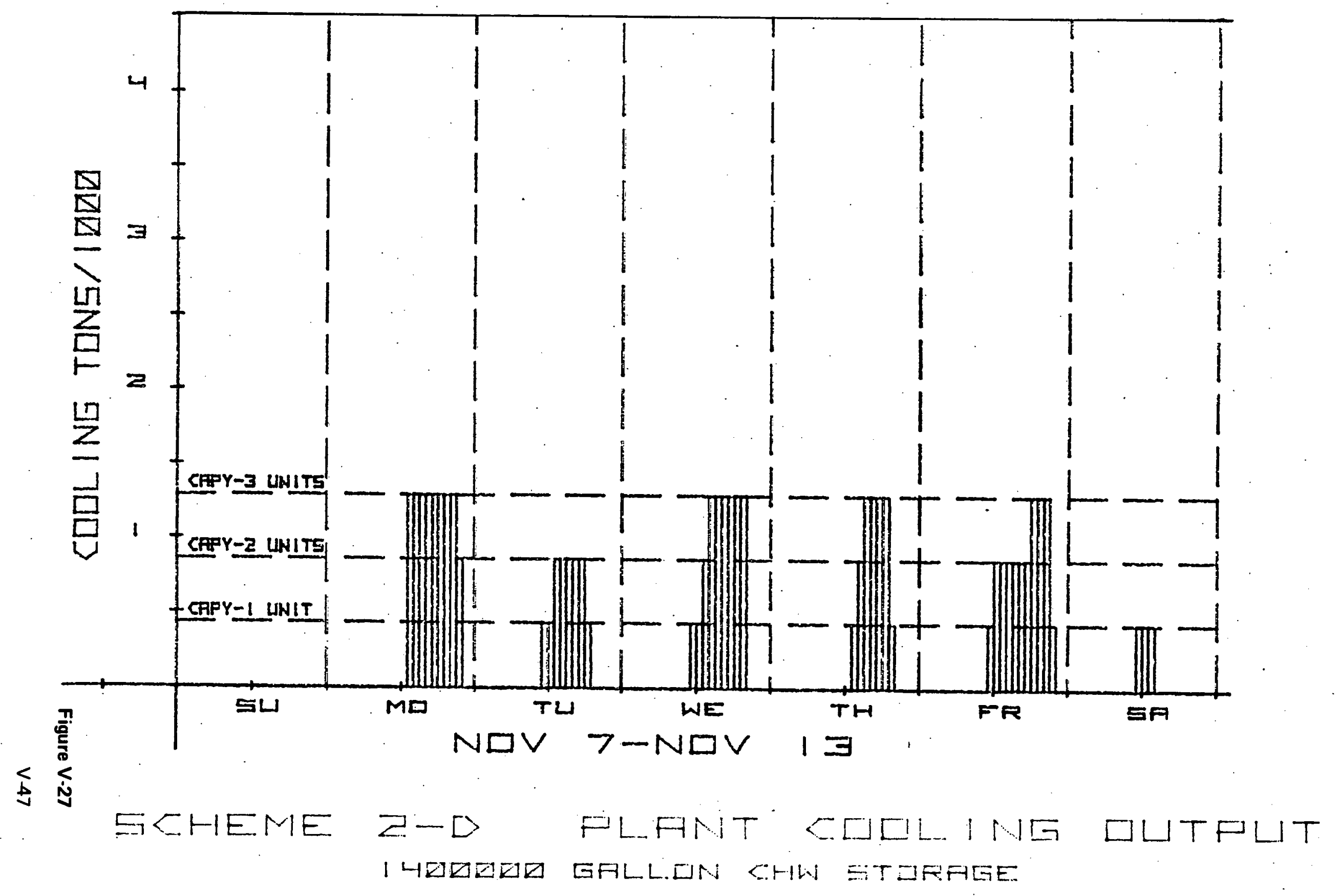




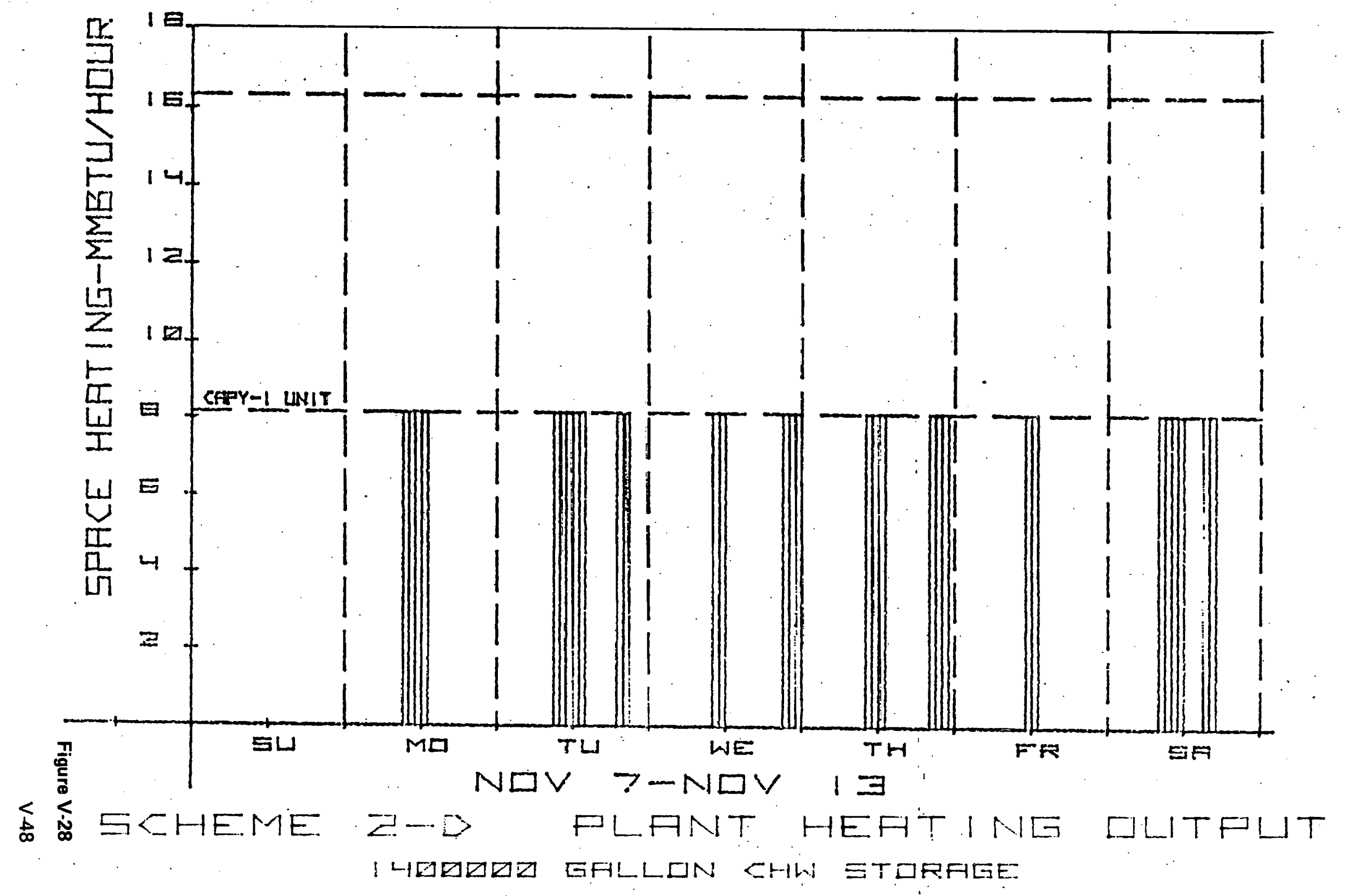


d. Plus the costs of permits, fees, construction management and administration fees.

These capital costs for the TIES schemes and also for the Conventional scheme and the standard Central Plant scheme for comparison, are tabulated in Table V-9.

\section{Annual Operating Cost}

This cost is arrived at from the combination of annual maintenance and energy cost. Electrical costs were calculated on the basis of DWP Schedule G-2 plus present fuel adjustment charges $(\$ .015 / \mathrm{KWH})$. The cost of fuel is based on $\$ .345$ per gallon. Annual maintenance costs were estimated from manufacturer's data for major overhauls and estimated housekeeping and routine maintenance. It should be noted that the TIES plant is assumed to be unattended. Start-up, shut-down and other operating and maintenance tasks are expected to be done by DWP personnel on a part time basis. Monitoring of essential operating points would be accomplished at DWP Central Control via leased telephone lines.

These annual operating costs for the TIES schemes and also for the Conventional and the standard Central Plant schemes for comparison, are tabulated in Table V-10.

\section{Annual Revenue}

Total annual revenue includes revenues for power produced, cooling and heating. The values for determining demand and energy revenue for electrical generation were assigned by DWP. The values for heating and cooling were based on average prevalent costs charged for these utilities by operators of central plants in the area. These values and amounts are tabulated in Table V-11.

\section{Bonding Costs and Income}

The following additional factors were considered and estimated by the Pasadena Redevelopment Agency's financial consultant for the TIES schemes.

(1) Insurance Reserve: $5 \%$ of construction cost.

(2) Cost of Bond Issuance: $\$ 125,000$ for all schemes.

(3) Investment Income: 5\% during the course of a 12 month construction period.

(4) Borrowing Rate: $7.1 / 2 \%$ (with 22 year amortization of principal). 


\section{Summary}

Table V-12 indicates the summary of the bonding feasibility analysis. As can be readily seen, none of the TIES schemes can support the annual owning and operating cost from annual revenue.

SCHEME NO.

CONVENTIONAL

CAPITAL COSTS

(ALL FIGURES IN THOUSANDS OF. DOLLARS)

\begin{tabular}{|c|c|c|c|c|}
\hline SCHEME NO. & $\begin{array}{c}\text { PLANT } \\
\text { STRUCTURE \& } \\
\text { UTILITIES }\end{array}$ & $\begin{array}{c}\text { M\&E, } \\
\text { MARK-UP \& } \\
\text { ESCALATION }\end{array}$ & $\begin{array}{l}\text { PERMITS, FEES, } \\
\text { CONST. MGMT., } \\
\text { ADMIN. }\end{array}$ & TOTAL \\
\hline CONVENTIONAL & - & 1,615 & 180.8 & $1,795.8$ \\
\hline $\begin{array}{l}\text { CENTRAL } \\
\text { COOL/HTG. }\end{array}$ & & & 3434 & \\
\hline PLANT & 490.0 & 1,937 & 343.4 & $2,770.4$ \\
\hline $1 \mathrm{~A}$ & 772.9 & 10,416 & 781.4 & $11,970.3$ \\
\hline 1B & $1,169.9$ & 8,019 & 681.4 & $9,870.3$ \\
\hline $1 \mathrm{C}$ & 1.280 .9 & 7.355 & 653.8 & 9.289 .7 \\
\hline 10 & $1,487.9$ & 6,349 & 613.8 & $8,350.7$ \\
\hline $1 E$ & $1,622.9$ & 5,634 & 584.8 & $7,841.7$ \\
\hline $2 A$ & $1,169.9$ & 7,269 & 643.9 & $9,082.8$ \\
\hline $2 B$ & $1,280.9$ & 6,673 & 619.7 & $8,573.6$ \\
\hline ?s. & $1,487.9$ & 6,067 & 599.7 & $8,164,6$ \\
\hline 20 & $1,622.9$ & 5,472 & 676.7 & $7,671.6$ \\
\hline $3 A$ & $1,169.9$ & 4,106 & 485.8 & $5,761.7$ \\
\hline $3 B$ & $1, \angle 8 \bar{U} \cdot y$ & 3,869 & $4 / 9.5$ & $5,629.4$ \\
\hline $3 \mathrm{C}$ & $1,487.9$ & 3,571 & 474.9 & $5,533.8$ \\
\hline 3D & $1,622.9$ & 3,361 & 471.2 & $5,455.1$ \\
\hline $4 A$ & $1,169.9$ & 8,091 & 685.0 & $9,945.9$ \\
\hline $4 B$ & $1,280.9$ & 7,371 & 654.6 & घ, З̇ub.b \\
\hline $4 C$ & $1,487.9$ & 6,476 & 620.2 & $8,584.1$ \\
\hline $4 D$ & $1,622.9$ & 5,835 & 594.9 & $8,052.8$ \\
\hline
\end{tabular}

"Based on $\$ 100,000$ for permits and fees, plus $5 \%$ construction management fees, plus $\$ 122,000$ for administration by PRA for TIES schemes and for the Central Cooling/Heating Plant scheme; and based on $\$ 100,000$ permits and fees plus $5 \%$ construction management fees for the Conventional scheme. 


\begin{tabular}{|c|c|c|c|c|c|}
\hline . & $\begin{array}{l}\text { ANNL } \\
\text { (ALL }\end{array}$ & $\begin{array}{l}\text { OPERA } \\
\text { GURES IN }\end{array}$ & $\begin{array}{l}\text { NG COSTS } \\
\text { IOUSANDS) }\end{array}$ & & \\
\hline SCHEME NO. & $\begin{array}{c}\text { FUEL/YR } \\
\text { (OIL) } \\
\text { GAL } \\
\end{array}$ & $\begin{array}{c}\text { ANNUAL } \\
\text { FUEL } \\
\text { COST } \\
\$ \\
\end{array}$ & $\begin{array}{c}\text { ANNUAL* } \\
\text { ELEC. } \\
\text { COST } \\
\$ \\
\end{array}$ & $\begin{array}{c}\text { ANNUAL } \\
\text { MAINT. } \\
\text { COST } \\
\$ \\
\end{array}$ & $\begin{array}{c}\text { TOTAL } \\
\text { ANNUAL } \\
\text { OPER. } \\
\text { COSTS } \\
\$ \\
\end{array}$ \\
\hline CONVENTIONAL & 32.3 & 11.1 & 328.6 & 40.0 & 379.7 \\
\hline $\begin{array}{l}\text { CENTRAL } \\
\text { COOL/HTG. }\end{array}$ & 871 & 301 & 1526 & 530 & 2357 \\
\hline & & 30.1 & 102.0 & 00.0 & 200.1 \\
\hline $1 \mathrm{~A}$ & 1,994 & 687.9 & 66.3 & 1.11 .8 & 866.0 \\
\hline $1 B$ & 1,438 & 496.1 & 64.5 & .95 .3 & 655.9 \\
\hline $1 \mathrm{C}$ & 1,424 & 491.3 & 63.0 & 94.0 & 648.3 \\
\hline 10 & 1,408 & 485.8 & 71.7 & 92.8 & 650.3 \\
\hline $1 E$ & 1,385 & 477.8 & 69.7 & 91.5 & 639.0 \\
\hline $2 A$ & 1,852 & 6.3R.9 & 57,1 & 77.6 & 773.6 \\
\hline $2 B$ & 1,817 & 626.9 & 56.3 & 75.9 & 759.1 \\
\hline $2 \mathrm{C}$ & 1.762 & 607.9 & 56.9 & 74.9 & 739.7 \\
\hline 2D & 1,691 & 583.4 & 59.5 & 73.4 & 716.3 \\
\hline $3 A$ & 794 & 273.9 & 67.7 & 101.8 & 443.4 \\
\hline $3 B$ & 786 & 271.2 & 64.6 & 100.1 & 435.9 \\
\hline $3 C$ & 777 & 268.1 & 65.4 & 98.6 & 432.1 \\
\hline 3D & 765 & 263.9 & 63.9 & 96.6 & 424.1 \\
\hline $4 A$ & 2,207 & 761.4 & 49.8 & 107.7 & 918.9 \\
\hline 4B & 2,136 & 736.9 & 49.7 & 106.1 & 892.7 \\
\hline $4 \mathrm{C}$ & 2,067 & 713.1 & 53.0 & 104.5 & 870.6 \\
\hline $4 D$ & 1,994 & 687.9 & 52.7 & 101.9 & 842.5 \\
\hline
\end{tabular}

Table V-10 
ANNUAL REVENUE.

(ALL FIGURES IN THOUSANDS)

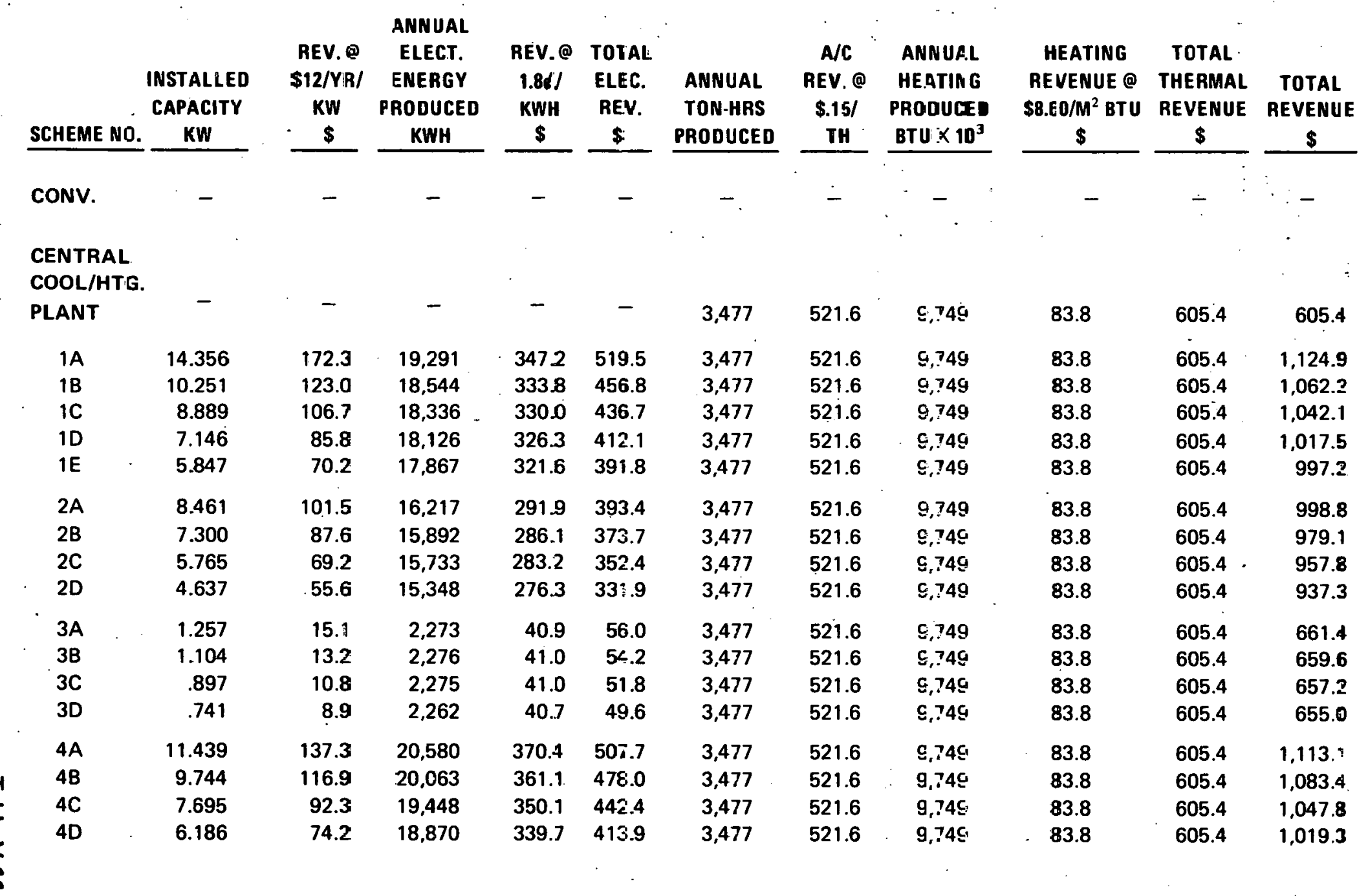


BONDING FEASIBILITY SUMMARY

(All Figures in Thousands of Dollars)

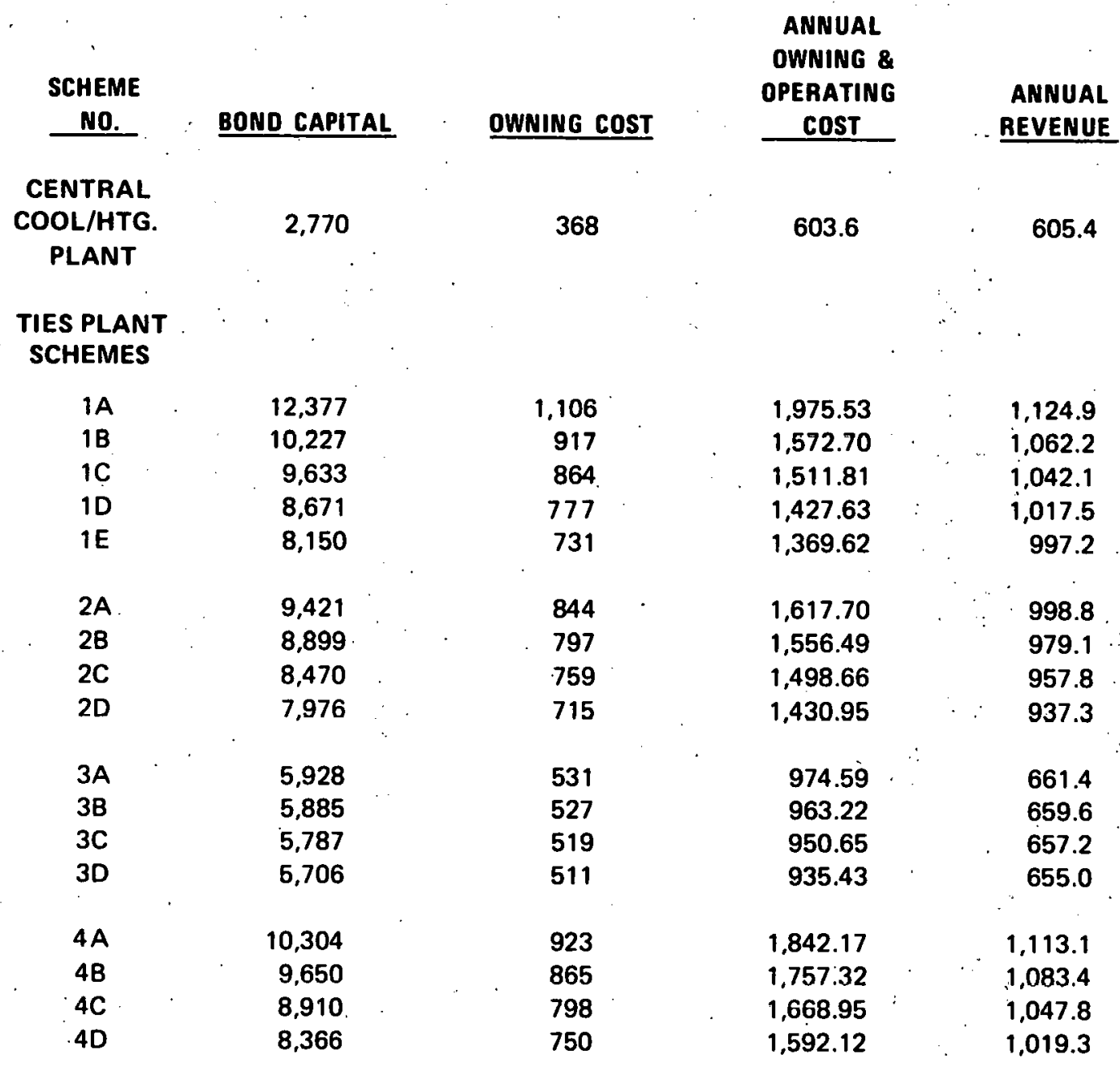

Táble V-12 


\section{DISCUSSION AND RECOMMENDATIONS}

\section{A. COMPARISON OF TIES SYSTEMS WITH THE CONVENTIONAL AND CENTRAL PLANT SYSTEMS}

The following conclusions resulted from the case study of the TIES plant for Pasadena:

\section{Energy Savings}

a. The yearly energy consumption of the various TIES schemes is compared in Table VI-1. This indicates that all TIES schemes analyzed will consume less energy annually than the assumed Conventional System method of providing cooling, heating and electric power services to the Energy Using Community.

With utilization of thermal storage, the energy savings are: $28 \%$ for the Diesel Engine System; 8\% for (both) Combustion Turbine Systems; and less than $1 \%$ for the Boiler/Steam Turbine System.

b. A TIES plant with a Diesel Engine System consumes approximately $21 \%$ less energy than a "standard" Central Cooling/Heating Plant. All other TIES plant systems studied consume slightly more energy than a Central Cooling/Heating Plant.

c. Utilization of storage for heating and cooling media results in reduced energy usage.

d. Schemes utilizing diesel engine generation and absorption refrigeration proved to be most energy efficient of the cycles studied.

e. A supplemental solar energy system designed to satisfy the domestic hot water needs, could provide approximately $0.5 \%$ annual fuel savings in conjunotion with all TIES schemes.

\section{Economic Feasibility Comparison}

a. General

Economic feasibility for a given TIES system in this study is defined as a system which can produce the required utilities at an equal or lower cost than conventional means. The basis for this comparison was determined to be the annual owning and operating cost. Only the most feasible of each of the base TIES schemes are compared to the Conventional and the Central Cooling/Heating Plant (Schemes IE, 2D, 3D and 4D). In all cases, these are the schemes with maximum thermal storage.

The Annual Owning and Operating Cost of the Central Cooling/Heating Plant is calculated on the same basis as the TIES plant on the assumption that the plant will be financed in an identical manner, experiencing the same fees and other costs estimated for the TIES plants. 


\section{COMPARISON OF SYSTEM ENERGY CONSUMPTION}

Conventional System $=36.9 \times 10^{10} \mathrm{BTU} / \mathrm{YR}$.

Central Plant System $=33.9 \times 10^{10}$ BTU/YR.

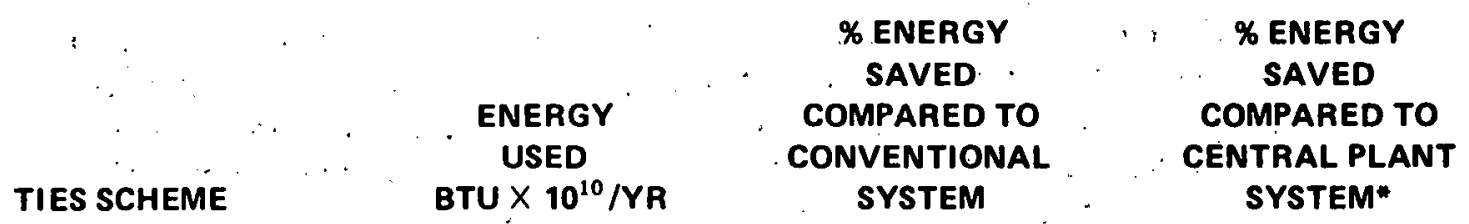

Diesel Engine

System:

Scheme 1A

1B

$1 E$
34.45

26.71

26.77
6.6

27.6

27.5
$-1.6$

21.2

21.0

Combustion Turbine-

Centrifugal Refrig.

System:

Scheme 2A

2D

Boiler/Steam

Turhine System:

Scheme 3A

3D
36.99

36.59
34.98

33.93
5.2

8.0
$-3.2$

0.0

Combustion Turbine-

Absorption Refrig.

System:

Scheme 4A

4D
35.09

34.14
4.9

7.5
$-9.1$

$-7.9$

* Negative values indicate more energy used than a Central Plant System. 
b. Summary

As indicated in Table VI-2, none of the TIES schemes are economically feasible in comparison to the Conventional. However, it is evident that the Central Cooling/Heating Plant is the most feasible scheme of all those evaluated. In fact, when a comparison of the annual owning and operating cost of the Central Cooling/Heating Plant is made against estimated annual revenue, it appears that this scheme could return a slight profit to the investor, and therefore justifies further study to optimize the design and to achieve the desired end results.

\section{FEASIBILITY COMPARISON}

TIES VS. CONVENTIONAL \& CENTRAL COOLING/HEATING PLANT

\begin{tabular}{|c|c|c|c|}
\hline \multicolumn{4}{|c|}{ (All Figures in Thousands of Dollars) } \\
\hline SCHEME & $\begin{array}{c}\text { TOTAL } \\
\text { ANNUAL } \\
\text { OWNING \& } \\
\text { OPERATING } \\
\text { COST }\end{array}$ & $\begin{array}{c}\text { REVENUE } \\
\text { FOR ELECTRIC } \\
\text { POWER } \\
\text { SOLD TO } \\
\text { DWP }\end{array}$ & $\begin{array}{c}\text { NET } \\
\text { HEATING-COOLING } \\
\text { SYSTEM ANNUAL } \\
\text { OWNING \& } \\
\text { OPERATIONS COST }\end{array}$ \\
\hline CONV. & 741.2 & 0 & 741.2 \\
\hline $\begin{array}{l}\text { CENTRAL } \\
\text { COOLING/HTG. } \\
\text { PLANT }\end{array}$ & 603.6 & 0 & 603.6 \\
\hline $1 E$ & 1370.0 & 321.6 & 1048.4 \\
\hline $2 D$ & 1431.3 & 276.3 & 1155.0 \\
\hline $3 D$ & 935.1 & 40.7 & 894.4 \\
\hline 4D & 1592.5 & 339.7 & 1252.8 \\
\hline
\end{tabular}

Table VI-2

\section{Impact on Air Quality}

\section{a. General}

The total emissions resulting from the installation of a TIES Plant is the sum of the emissions from the TIES Plant prime movers, plus the emissions from the Utility Co. resulting from the generation of grid power drawn by the TIES Plant to meet electrical loads. 
Incremental emission rates for the power drawn from the grid were obtained from the Pasadena Water and Power Dept. as:

$5 \mathrm{lb} /$ megawatt-hour of $\mathrm{NO}_{X}$

$4 \frac{1}{2} \mathrm{Ib} /$ megawatt-hour of $\mathrm{SO}_{\mathrm{x}}$

$\mathrm{NO}_{\mathbf{x}}$ (nitrogen oxides) emissions determined from EPA data and manufacturers were established at:

$.4 \mathrm{lb} / 10^{6}$ BTU or .055 lh/gal for họilers

$2.69 \mathrm{lb} / 10^{x}$ DTU Ui . $37 \mathrm{lW} / \mathrm{yal}$ ful diesels

$.5 \mathrm{lb} / 10^{6}$ BTU or $.07 \mathrm{lb} / \mathrm{gal}$ for turbines

$\mathrm{SO}_{x}$ (sulphur oxides) emissions are determined directly from the sulphur content of the input fuel, since $95 \%$ of the sulphur content is discharged as oxides to the alıuvsphiere. For the Pasadena project only low sulphur content fuels were considered:

Boiler and Diesel Schemes: $7.8 \mathrm{lb} / \mathrm{gal}$ of fuel oil at $0.35 \%$ by weight sulphur yields $.0546 \mathrm{lb} / \mathrm{gal}$ oxides of sulphur.

Internal Conmbustion Turbine Schemes: $7.2 \mathrm{lb} / \mathrm{gal}$ of fuel oil at $0.2 \%$ by woight sulphur yields $.0288 \mathrm{lb} / \mathrm{gal}$ oxides of sulphur.

Table VI-3 indicates the summary of the $\mathrm{NO}_{X}$ and $\mathrm{SO}_{X}$ emissions for each scheme. No evaluation of particulates was made since the data was unavailable from DWP.

b. Summary

(1) None of the diesel schemes is acceptable from an air quality standpoint because of the $\mathrm{NO}_{X}$ emissions. The balance of the TIES schemes appear to be acceptable, although somewhat marginally so. The most acceptable scheme is the Central Cooling/Heating Plant.

(2) Other than the diesel schemes, the TIES schemes appear to be acceptable within the present air quality regulations of Los Angeles County, although the total pollution rate is increased by all TIES schemes.

(3) A supplemental solar energy system for domestic hot water reduces total pollutants discharged for all TIES schemes by approximately $0.2 \%$. 


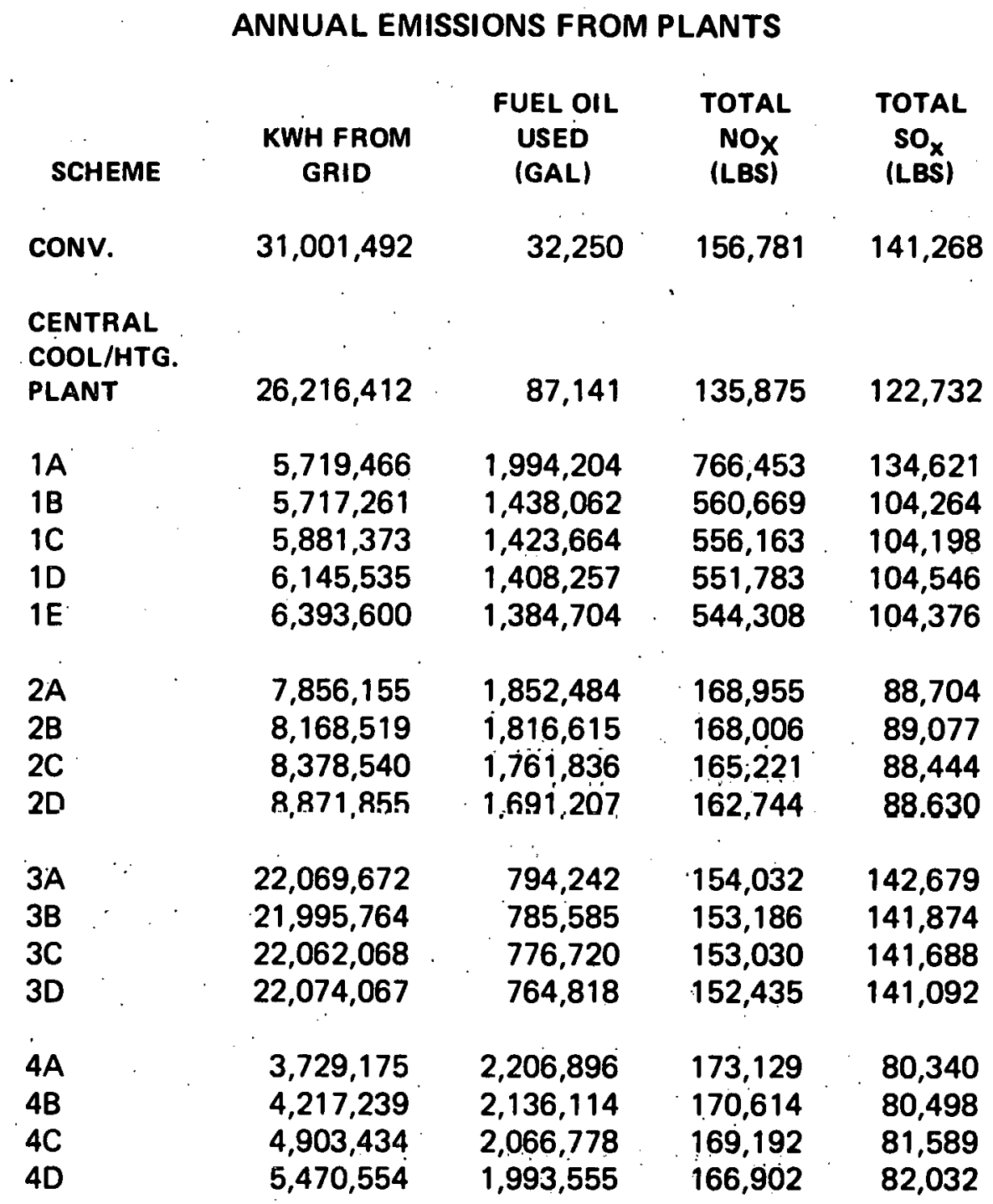

Table VI-3

\section{B. COSTS OF GENERATING ELECTRICITY FOR TIES SCHEMES}

The costs of generating electricity for various TIES schemes is shown in Table VI-4.

This shows that the generating cost varied from $4.3 \% / \mathrm{KWH}$ for the Diesel Engine System with maximum thermal storage to $5.1 \notin / \mathrm{KWH}$ for the best Combustion Turbine System.

The Boiler/Steam Turbine System cost was $14.6 \AA / \mathrm{KWH}$ with maximum thermal storage.

All of these costs are considerably higher than the price of $1.8 \notin / \mathrm{KWH}$, which the utility company DWP would pay for electric energy delivered to the grid. 


\section{COSTS OF GENERATING ELECTRICITY FOR TIES SCHEME}

\begin{tabular}{|c|c|c|c|c|c|c|c|}
\hline $\begin{array}{l}\text { SCHEME } \\
\text { NO. }\end{array}$ & $\begin{array}{c}\text { KW } \\
\text { INST.ALLED }\end{array}$ & $\begin{array}{l}\text { KWH/YR PRODUCED } \\
\text { KW INSTALLLED }\end{array}$ & $\begin{array}{c}\text { KWH/YR } \\
\text { PRODUCED } \\
\text { (1000's) }\end{array}$ & $\begin{array}{c}\text { TOTAL } \\
\text { ANNUAL } \\
\text { OWNING \& } \\
\text { OPERATING } \\
\text { COST } \\
\text { (\$1000) }\end{array}$ & $\begin{array}{l}\text { COOLING } \\
\text { HEATING } \\
\text { REVENUE } \\
\text { (\$1000) }\end{array}$ & $\begin{array}{l}\text { NET } \\
\text { COST' } \\
\text { FOR } \\
\text { POWER } \\
\text { (\$1000) }\end{array}$ & $\underset{(\$)}{\operatorname{cost/KWh}}$ \\
\hline $1 \mathrm{~A}$ & 14,356 & 1,134 & 16,280 & 1.975 .3 & 305.4 & $1,369.9$ & .084 \\
\hline 1B & 10,251 & 1,8018 & 18,534 & 1.572 .7 & 505.4 & 967.3 & .052 \\
\hline $1 E$ & $5 ; 847$ & 3,056 & 17,868 & $1,369.6$ & 605.4 & 764.2 & .043 \\
\hline $2 A$ & 8,461 & $2,0 \subseteq 8$ & 16,990 & $1,617.7$ & 605.4 & $1,012.3$ & .060 \\
\hline 2D & 4,637 & 3,480 & 16,137 & $1,431.0$ & 605.4 & 825.6 & .051 \\
\hline $3 A$ & 1,257 & 1,808 & 2,273 & 974.6 & 605.4 & 369.2 & . 162 \\
\hline 3D & 741 & 3,053 & 2,262 & 935.4 & 605.4 & 330.0 & .146 \\
\hline $4 A$ & 11,439 & 1,799 & 20,579 & $1,842.2$ & 605.4 & $1,236.8$ & .060 \\
\hline 4D & 6,186 & 3,050 & 18,867 & $1,592.1$ & 605.4 & 986.7 & .052 \\
\hline
\end{tabular}

$\frac{j}{b} \quad \frac{\overrightarrow{0}}{\sigma}$ 


\section{DISCUSSION OF SYSTEMS STUDIED}

The following conclusions can be drawn from the systems studies:

1. None of the TIES schemes analyzed proved financially feasible. This is in part due to the fact that revenue for power generation was not sufficient to pay for the cost of installing or operating the power generation equipment. In addition, there was insufficient heating usage and, therefore, insufficient heating revenue. This was due to the location and type of project.

2. A standard Central Cooling/Heating Plant is marginally feasible-economically.

3. Minimum capital investment in the TIES schemes is achieved with maximum utilization of storage for heating and cooling media.

4. Thermal storage in conjunction with a TIES plant, can also be used in design of supplemental peaking plants for Electrical Utilities.

5. A supplemental solar system for domestic hot water is not economically feasible primarily due to high initial cost,

6. Applications involving more weekly hours of operation and having more equal summer and winter thermal requirements, would fare bettereconomically.

7. It is unlikely that the TIES concept will prove economically feasible for communities where cooling is the major thermal demand being served.

8. The concept of producing high pressure steam for a backpressure turbine generator, in order to produce electric power and then reducing to low pressure to meet the cooling requirements, (Scheme Group 4) does not appear to be justifiable from either an energy or cost point-of:view.

\section{RECOMMENDATIONS}

1. This study results in the following recommendations:

a. That the Energy Using Community in Pasadena, California purchase electrical power from the local utility company.

b. That a further study be made as to the economic feasibility of obtaining cooling and heating media from a Central Cooling/Heating Plant to serve the community's thermal needs. 


\section{Recommendations for Further TIES Study}

a. Generally available computer programs cannot directly accomplish the type of analysis desired, an economical, simple-to-use program geared to optimization and sensitivity analyses of TIES plants should be developed.

b. Future TIES studies should be funded for industrial, residential, university and health facility communities, located in varied climatalogical regions, in order to determine the probable national impact of the TIES concept.

c. Additional load profile data for usage of various utility systems should be determined by actual metering of existing facilitios.

d. Future TIES studies should only include evaluation of systems which are likely to be environmentally acceptable.

e. This study compares the TIES plant energy use with the average heat rate of the utility company. This may or may not be valid, depending on time of day and other factors. TIES power output may at times reduce the utility company's plant efficiency by reducing the loading of an efficient plant. On the other hand, TIES output may eliminate operation of a peaking unit which has a lower than average efficiency. This complex interrelationship requires careful input from the utility company involved. 


\section{GLOSSARY}

Capacity: The maximum output for which a component, subsystem, or system is rated.

Combined Cycle: The type of plant arrangement in which a combustion turbine drives a generator, and the waste heat from the turbine is recovered in the form of steam which drives a second generator via a steam turbine.

Commercial Article: A manufactured subsystem or component which (1) is commercially available (2) is listed in commercial catalogs showing overall physical and performance characteristics and ratings (3) has been in commercial use and (4) can be covered by warranty or performance bond.

Component: A hardware element.

Demand: The peak requirement imposed upon a utility within a given period of time.

Efficiency: The ratio of the effective or useful output to the corresponding input to the system, subsystem or component.

Energy Conversion Subsystem: The arrangement of components which serve to transform one fundamental form of energy (thermal, electrical, mechanical, chemical) to another. .

Energy Distribution Subsystem: The arrangement of components which serves to bring energy from the central plant to a specified location on each site.

Fuel Conversion Subsystem: The arrangement of components which serve to transform an input fuel to another form, i.e. from solid to liquid or gas, without changing its fundamental form (thermal, electrical, mechanical or chemical).

Fuel Processing Subsystem: The arrangement of components which serve as an intermediate step in the transformation of a raw fuel into a fuel more readily usable by energy conversion subsystems.

High-Grade BTU: Thermal energy which has the potential to perform effective mechanical work as well as to provide heat.

Load Profile: A curve showing the demand for a service by the site plotted against time of occurrence.

Low-Grade BTU: Thermal energy which has the potential to provide heating.

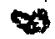

Prime Mover: A component which produces shaft output (mechanical) work.

Recovered Heat: That heat which is normally an unused by-product of an energy conversion process, but which is reclaimed in a TIES plant and converted for mechanical or thermal use.

Service: Energy community requirement expressed in its utilization form.

Solid Waste: All. unwanted or discarded solid materials of the energy community.

Sub-system: An arrangement of components which serve to perform one of the major functions of a total system. 
System: The arrangement of sub-systems which expresses the complete energy interrelationship.

Thermal Conversion Sub-system: The arrangement of components which serves to recover input heat of one form and by means of heat exchangers, etc., transform the heat into a form more readily usable for satisfying thermal loads of the site.

Utility: Energy product or by-product of an energy plant. 
APPENDIX A

FACTORS USED IN LOAD CALCULATIONS

Reference: Pending State of California Energy Conservation Standards for New Nonresidential Buildings, (Title 24).

1. CITY OF BURBANK WEATHER

(0.5\% Design Data)

Winter Design Dry Bulb Temperature: $36^{\circ} \mathrm{F}$

Summer Design Dry Bulb Temperture: $94^{\circ} \mathrm{F}$

Summer Design Wet Bulb Temperature: $70^{\circ} \mathrm{F}$

Annual Degree Days: 1694

Latitude: $\quad 34^{\circ}$ North

Elevation: 864 feet

2. WALL CONSTRUCTION - RETAIL CENTER AND DEPARTMENT STORES

Assumed Hoavy; 60-80 LB/SQ. FT. -5 hour average

Maximum $U_{o w}=0.43$ (Figure 4-1, Section T20-1493)

Assumed Fenestration $=16 \%$ (unshaded glass)

Required $U$ value of wall $=0.40 \mathrm{BTU} / \mathrm{HR} \mathrm{Ft}^{2}{ }^{\circ} \mathrm{F}$

3. WALL CONSTRUCTION - OFFICE BUILDINGS

Assumed Light, 20-30 LB/SO. FT. -3 hour average

Maximum $U_{o w}=0.43$ (Figure 4-1, Section T20-1493)

Assumed Fenestration $=32 \%$ Glass, Moderate Shading with open weave drape

Required $U$ value of $\mathrm{Net} W$ all $=0.10 \mathrm{BTU} / \mathrm{HR} \mathrm{Ft}^{2}{ }^{\circ} \mathrm{F}$

4. ROOFS

Figure 4-2, Section T20-1493: Required $\mathrm{U}_{\mathrm{OR}}$ value is $0.10 \mathrm{BTU} / \mathrm{HR} \mathrm{Ft}^{2}{ }^{\circ} \mathrm{F}$. Skylight in retail center is calculated $2.5 \%$ of gross roof, with assumed $U_{g}=1.1$, therefore, retail center net roof, must have a $\mathrm{U}$ value of $.074 \mathrm{BTU} / \mathrm{HR} \mathrm{Ft}^{2}{ }^{\circ} \mathrm{F}$.

5. FLOORS OVER UNHEATED SPACE

Figure 4-5, Section T20-1493: Maximum $U_{f}=0.26 \mathrm{BTU} / \mathrm{HR} \mathrm{Ft}^{2}{ }^{\circ} \mathrm{F}$. (Note, this will require insulation between parking space and rental space.) 
APPENDIX B

FACTORS USED TO DEVELOP TENANT AREA

ALLOCATIONS AND ELECTRICAL LOADS

1. DEPARTMENT STORES

J.C. Penney - 144,680 Sq. Ft.

Broadway - 149,030 Sq. Ft.

$\begin{array}{cc}\text { SELLING } & \text { SUPPORT } \\ \text { AREA } & \text { AREA } \\ \text { (Sales) } & \text { (Stock) }\end{array}$

SPECIAL

AREA

AREA DIVISION

Merchandising

Stock Fitting

Tailor Shop

$70 \%$

Restaurant

$25 \%$

3.6

2.0

2.0

General Lighting

Showcase-Display

Vert. Transp.

Steam Boiler

Kitchen - W/FT ${ }^{2}$

2.4

$20 \mathrm{KW}$

$$
\text { (=50\% Rest. Area) }
$$

Kitchen Fans

Tailor Shop Lights

Christmas Lights

Orcupanay - SF/Person

0.25

$2 \%$

$3 \%$

2. GENERAL RETAIL (SHOPS)

30

300

20

$30 \mathrm{KW}$ Tailor Shop $20 \mathrm{~W} / \mathrm{FT}^{2}$

$$
\begin{aligned}
& 2 \mathrm{~W} / \mathrm{FT}^{2} \\
& 5 \mathrm{~W} / \mathrm{FT}^{2}
\end{aligned}
$$

2. GENERAL RETAIL (SHOPS)

TYPE

TOTAL

AREA

RETAIL

SERVICE

Women's Department

64,110

31,900

Men's Department

41,370

Jr. Department

16,420

Household

31,900

Shoes

67,900

Seasonal \& Misc.

20,210

$80 \%$
$80 \%$
$80 \%$
$85 \%$
$75 \%$
$85 \%$
$90 \%$

$20 \%$

$20 \%$

$20 \%$

$15 \%$

$25 \%$

$15 \%$

$10 \%$ 
LIGHTING

General

Showcase-Display

For Jewelry

Christmas Lights

Occupancy - SF/Person

3. FOOD SERVICE (RESTAURANTS)

Area $=10.2 \% \times 315,800 S F=31,580$ SF

SEATING

Area Division

Lighting W/FT ${ }^{2}$

Misc. Power W/FT ${ }^{2}$

Kitchen Fans

Occupaney - SF/Persün
RETAIL

3.6

2.5

3.5

0.25

30
SERVICE

2.0

300

4. COMMON AREAS

ENCLOSED MALL

Area $=80,000 \mathrm{Sq}$. Ft. (Net occupied floor area)

L.ighting $=1.5 \mathrm{~W} / \mathrm{FT}^{2}$

Occupancy $=1$ person $/ 100$ Sq. $\mathrm{Ft}$.

STAIRS, EXITS, SERVICE CORRIDORS

Area $=45,700 \mathrm{Sq}$. $\mathrm{Ft}$.

Lighting $=1.3 \mathrm{~W} / \mathrm{FT}^{2}$

Occupancy $=1$ person $/ 300 \mathrm{Sq} . \mathrm{Ft}$.

PARKING GARAGES

LIghting $=0.4 \mathrm{~W} / \mathrm{rI}^{2}$

Fall Puwer $=1.2 \mathrm{~W} / \mathrm{FT}^{2}$

Occupancy $=1$ person $/ 200 \mathrm{Sq} . \mathrm{Ft}$.

LANDSCAPED AREA

Lighting $=0.5 \mathrm{~W} / \mathrm{FT}^{2}$ 
5. OFFICE SPACE AND NON-RETAIL SPACE

$60,000 \mathrm{SF}+3.1 \%$ of $315,800 \mathrm{SF}=9,790 \mathrm{SF}$

OCCUPIED

SUPPORT

Area Division

$85 \%$

$15 \%$

Lighting Load $W / \mathrm{FT}^{2}$

2/3 Task @ 4.8

3.7

1.5

3.2

1.5

$1 / 3$ General @ 1.6

0.5

2 @ $30 \mathrm{HP}$ (Grd..F/r. Only)

Elevators (2/Office BIdg.)

Misc. Power W/FT ${ }^{2}$ Misc. Small Loads

0.5

0.1

Occupancy - SF/Person

100

300

\section{PEAK OCCUPANCY ESTIMATES}

Reference: Uniform Building Code

USE

$\mathrm{FT}^{2} /$ OCCUPANT

Retail Space 30

Dining Rooms

15

Store Rooms - exits, etc.

300

Mall Area

100

100

Office Area

30

Bank Area (Same as Retail)

(1st FIr. Office Bldgs.)

$1 / 3$ of total occupancy is considered employees, except in office space where 3/4 are considered employees.

7. HOT WATER USAGE - PEAK

Lavaturies required per Uniform Plumbing Code; Appendix $C$.

NO. OF PEOPLE

$1: 15$

16-35

$36-60$

$61-90$

91-125
PLUMBING FIXTURES

REQUIRED

One additional for each 45 persons over 125. 
8. FAN POWER CALCULATIONS

Fan HP $=\frac{C F M \times \text { Total Pressure }}{6356 \times \text { Efficiency }}$

$746 \mathrm{Fan} H P=F$ an Watts

Supply Fan CFM $\times$ Total Pressure is limited to $0.5 / \mathrm{Sq}$. Ft. by T20-1506 California Administrative Code.

Fan and Motor Efficiency is estimated to be .60 .

Therefore, Supply Fan W/Sq. Ft. $=\frac{5.0 \times 746}{6356 \times .60}$

$$
\begin{aligned}
= & 0.98 \\
& \text { Say } 1.0 \mathrm{Wal} / \mathrm{Su} . \mathrm{Ft} .
\end{aligned}
$$

Return Fan @ 25\% SP, 80\% Air $=0.20 \mathrm{~W} / \mathrm{FT}^{2}$

Exhaust Fan @ 30\% SP, 15\% Air. $=0.05 \mathrm{~W} / \mathrm{FT}^{2}$

For VAV fans, discharge damper control is assumed, and hourly used by supply and return fans will vary directly with supply CFM.

B-4 
APPENDIX C

ESTIMATED DOMESTIC HOT WATER HEATING LOADS

AREA SERVED

RATE GPH

TEMP. RISE

$\mathrm{MBH}$

(degrees)

General Retail and

Shopping, Non-Retail

320

50-120

200

J.C. Penneys Retail

140

50-120

85

Broadway Retail

140

50-120

85

Office Buildings

125

50-120

80

Shopping Plaza Kit.

(2 @ 200 GPH each)

400

$50-140$

300

Dept. Store Rest.

(2@ $30 \mathrm{GPH}$ each)

60

50-140

50

C-1 
APPENDIX D

\section{ELECTRICAL LOADS AND LOAD PROFILES}

1. ELECTRICAL LOADS

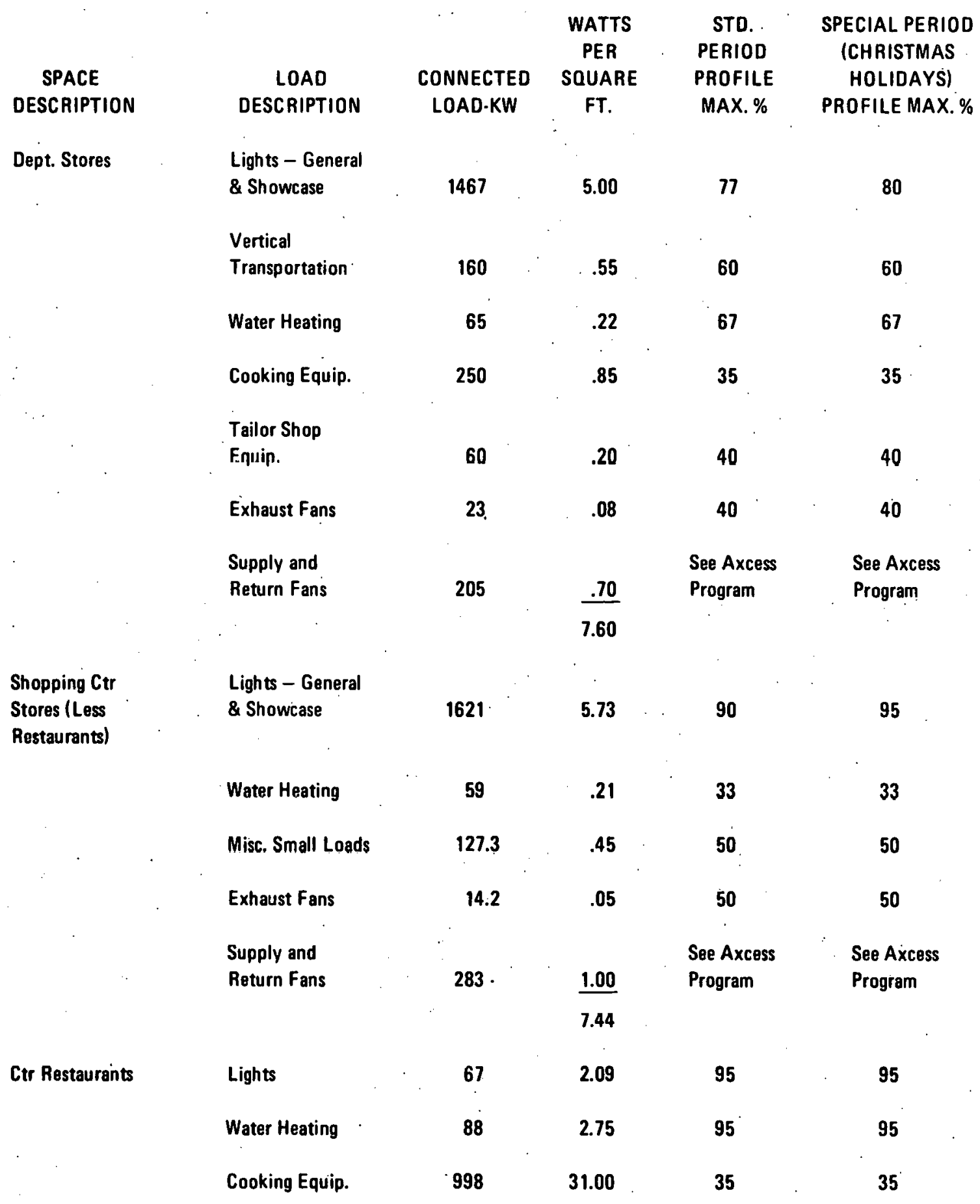




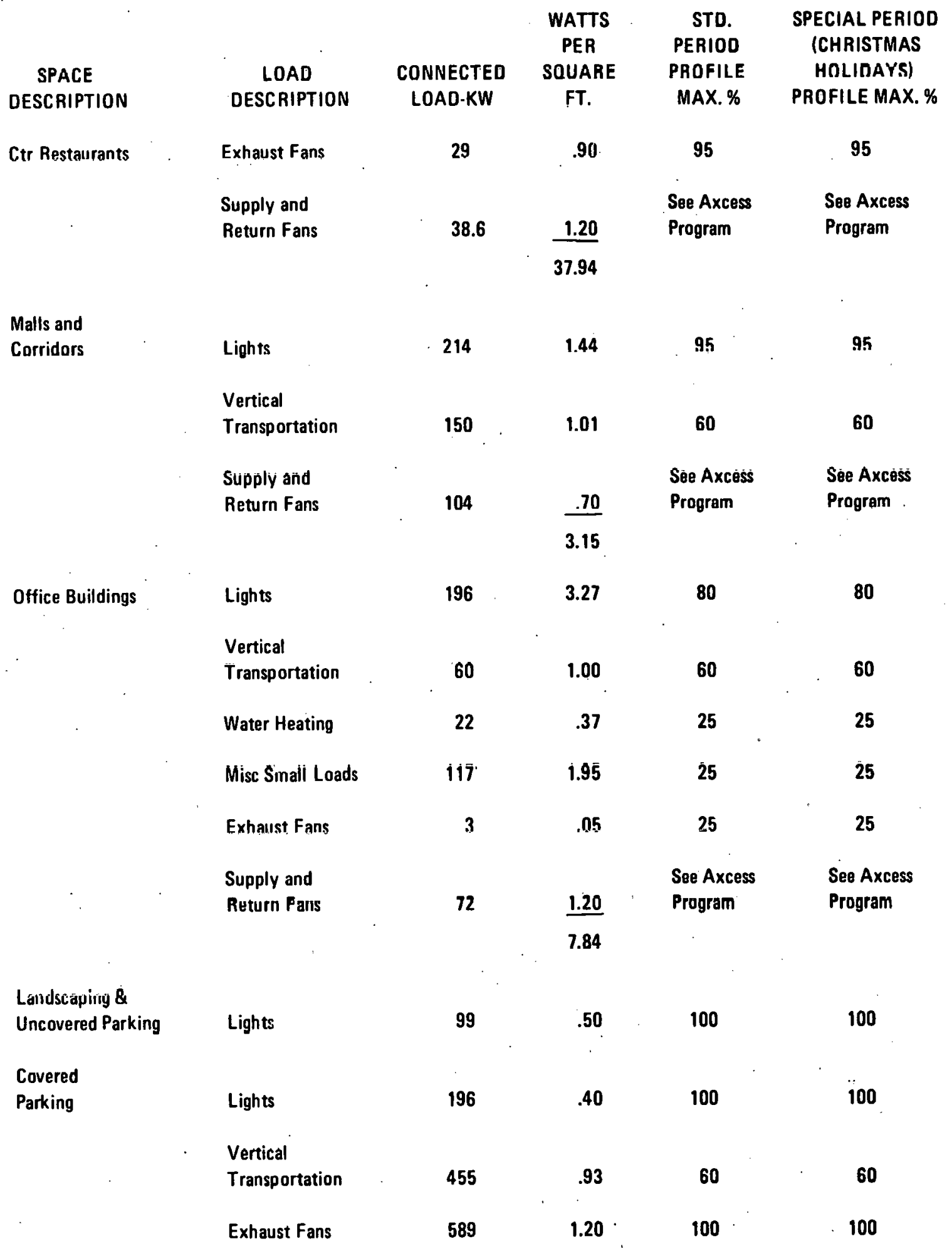


LIGHTS:

DEPT. STORES: PROFLE I WEEKDAY WEEKDAY CHRISTMAS -...-..

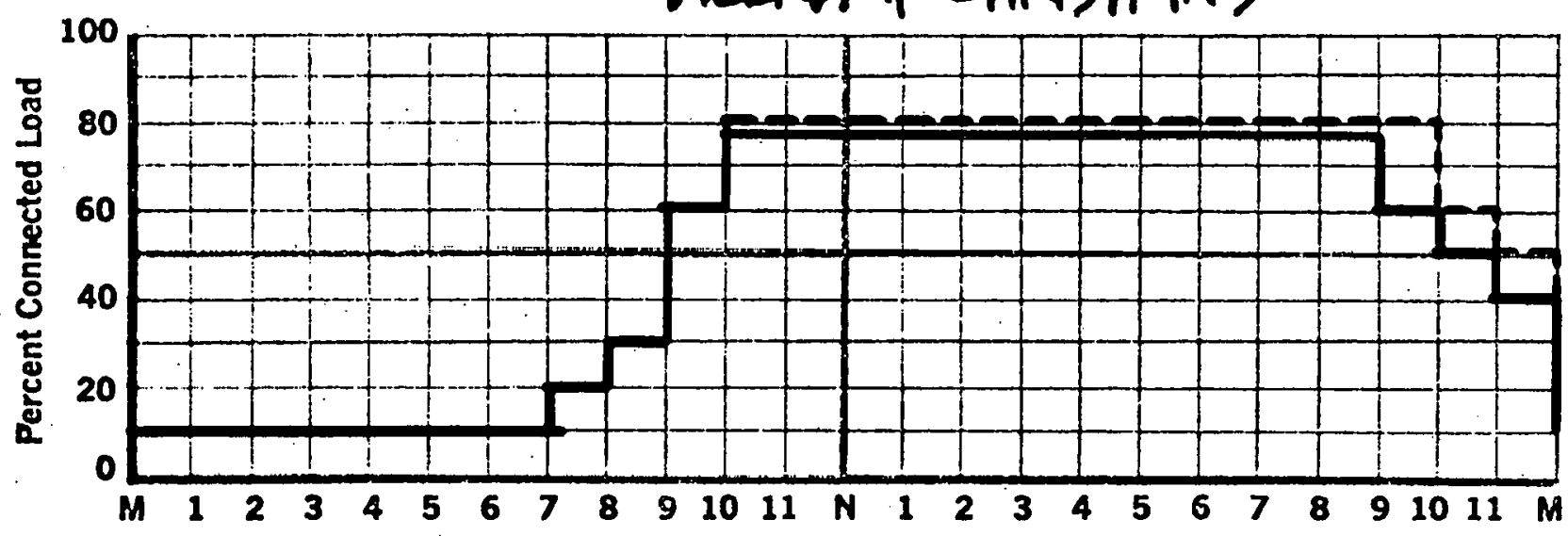

SATURDAY SATURDAY CHRISTMAS

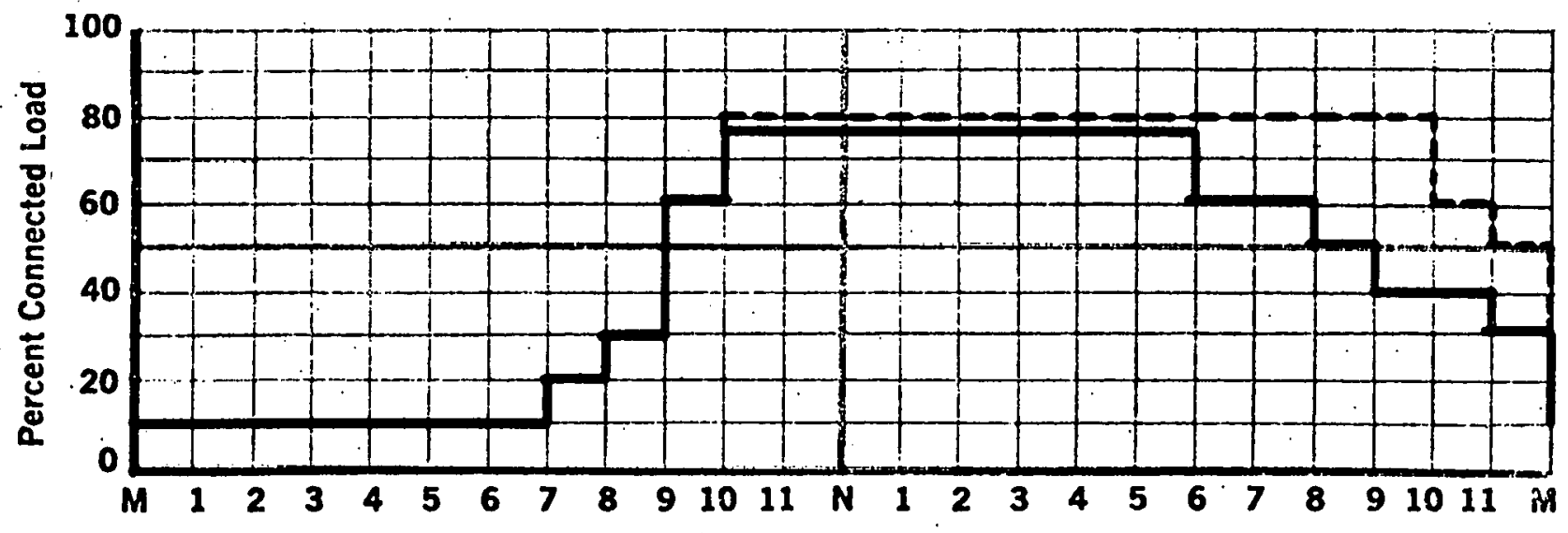

D-3 


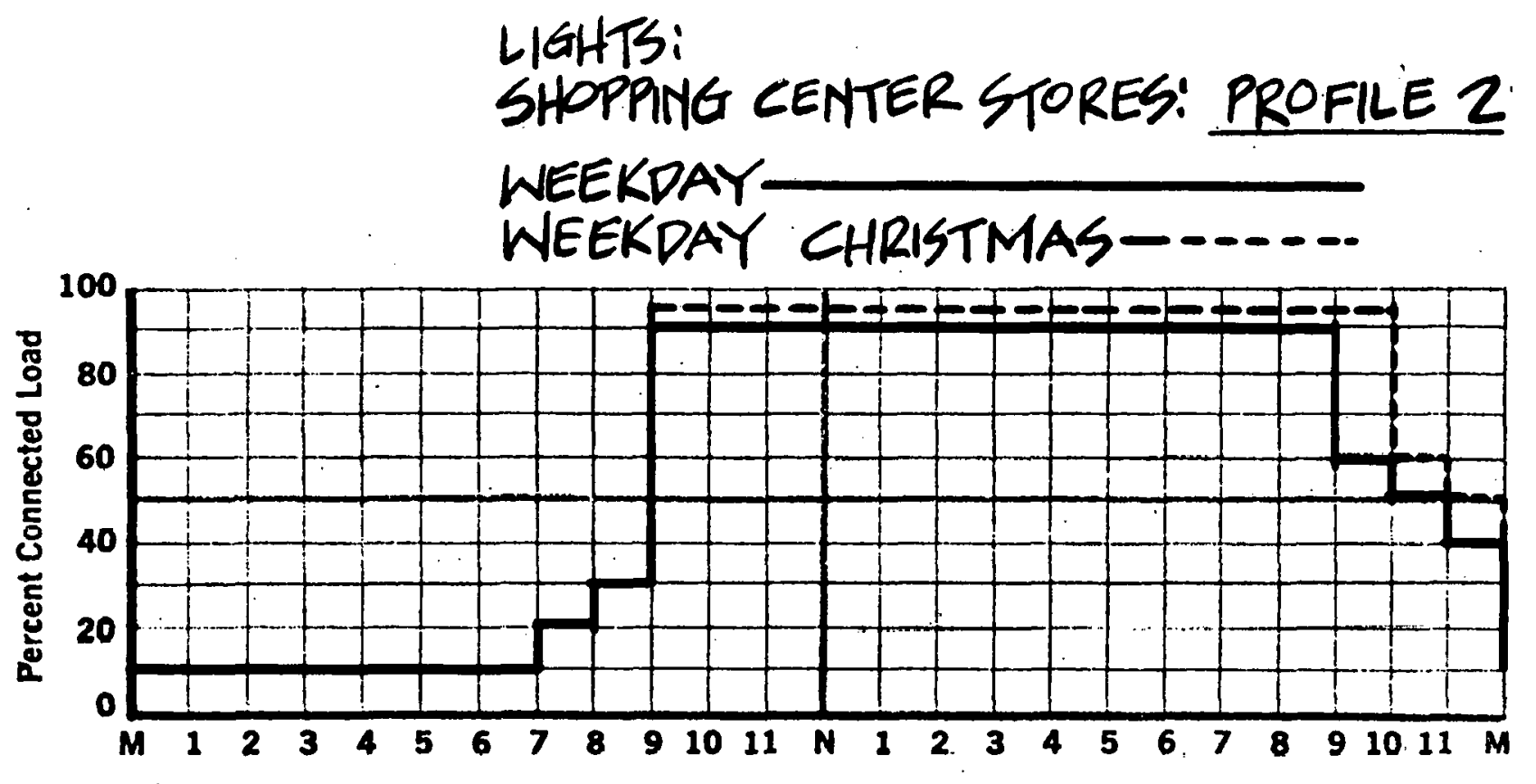

SATIRDAY CHRSTMAS--:----

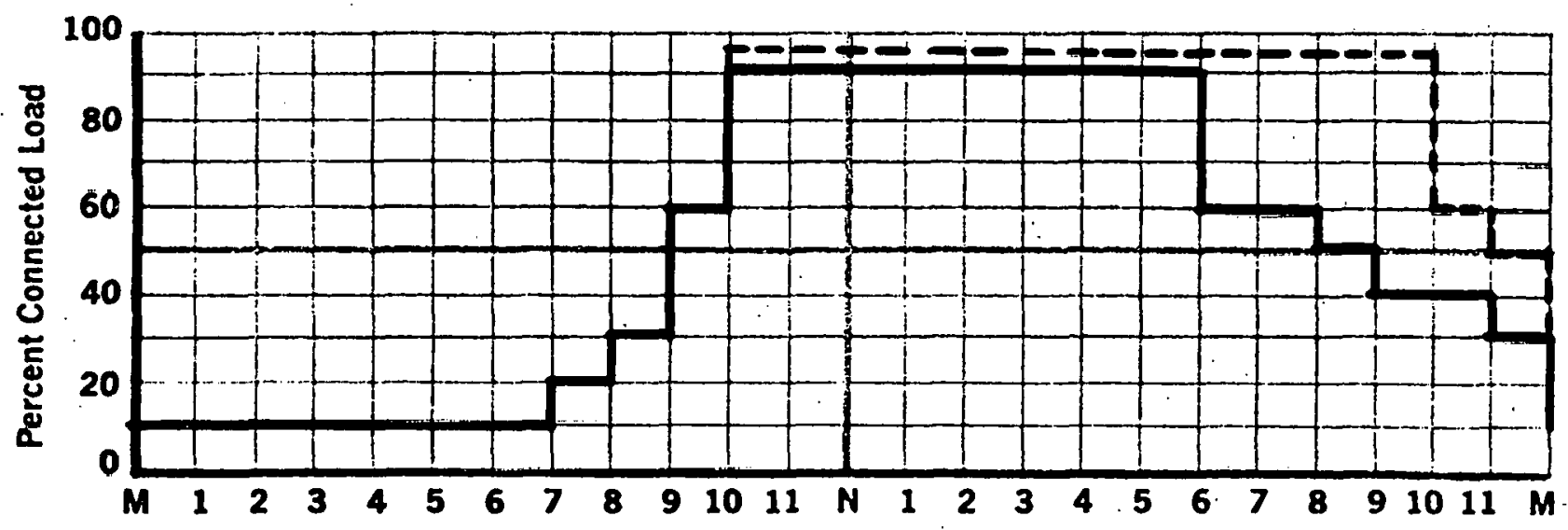



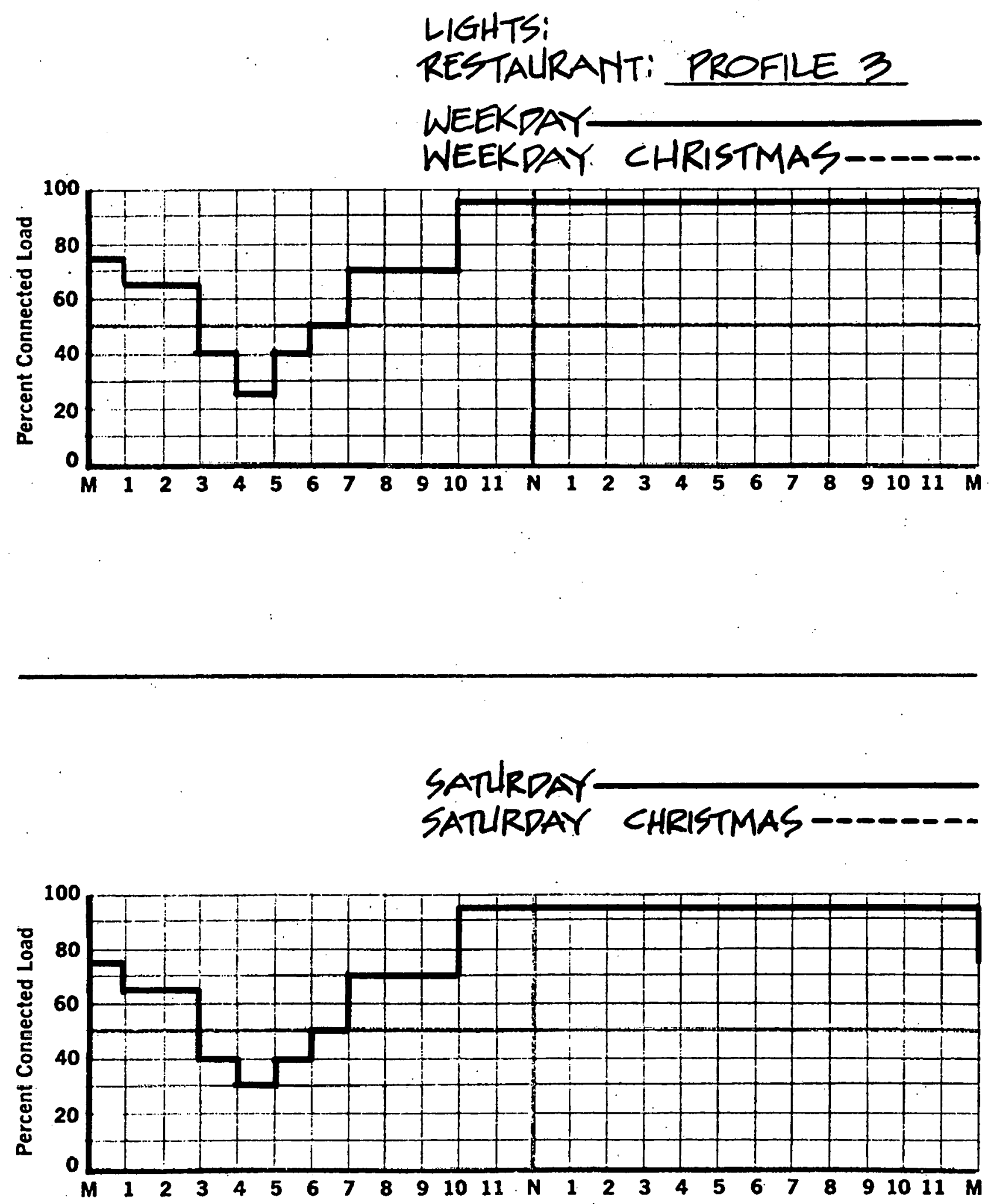
LIGHTS:

MALL ECORRIDORS: PROFILE 4 WEEKDAY

WEEKDAY CHRISTMAS------
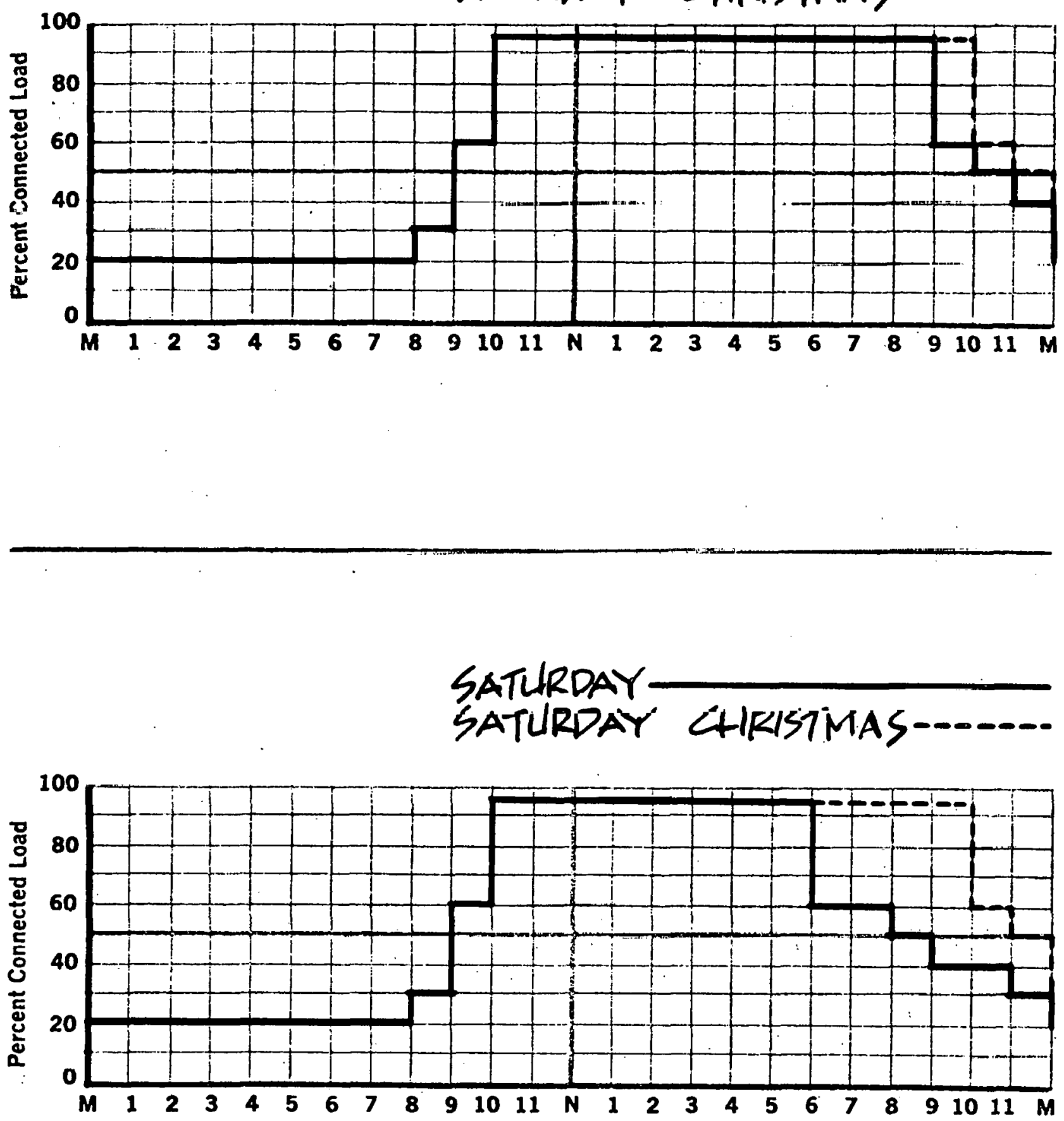


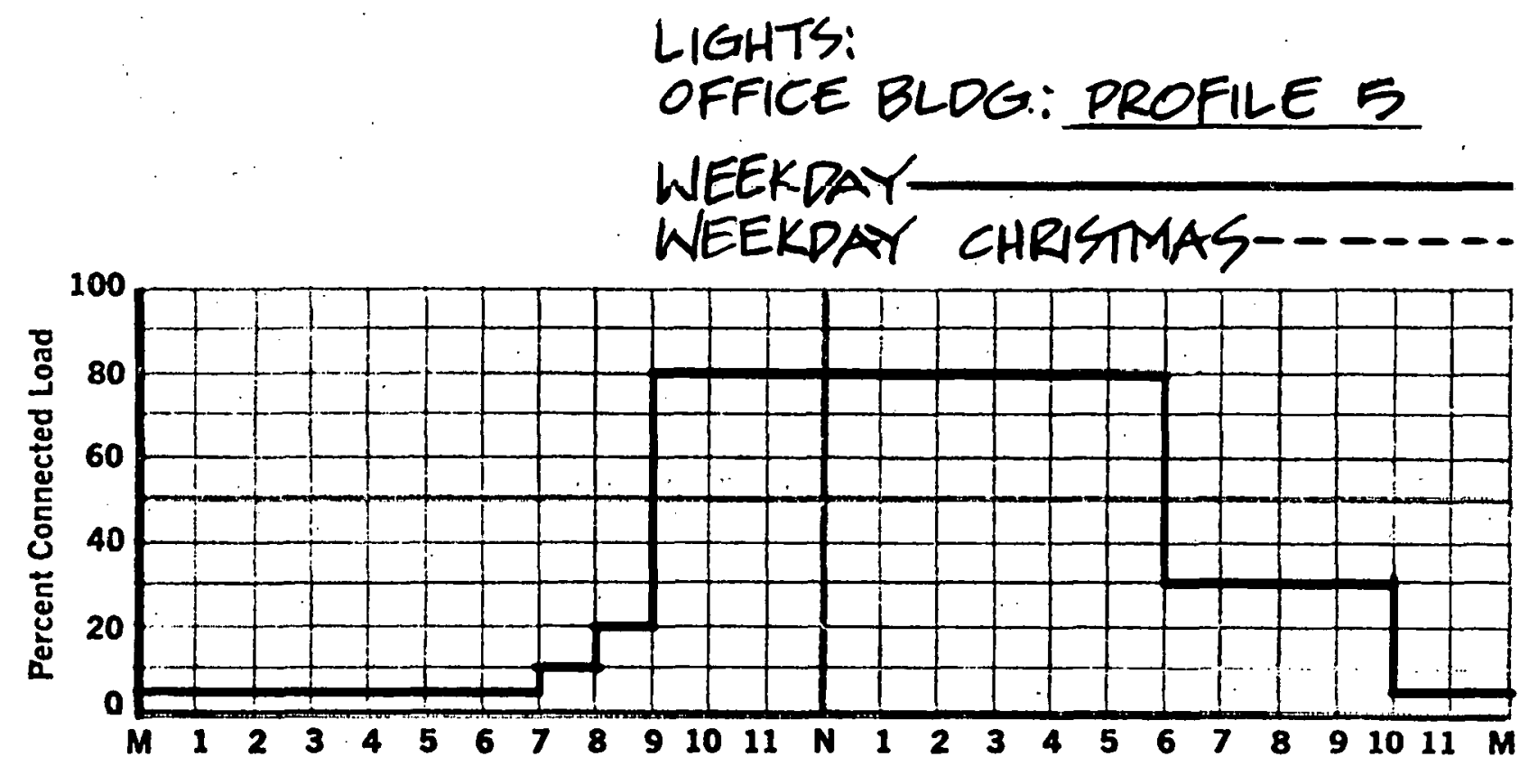

SATURPAY

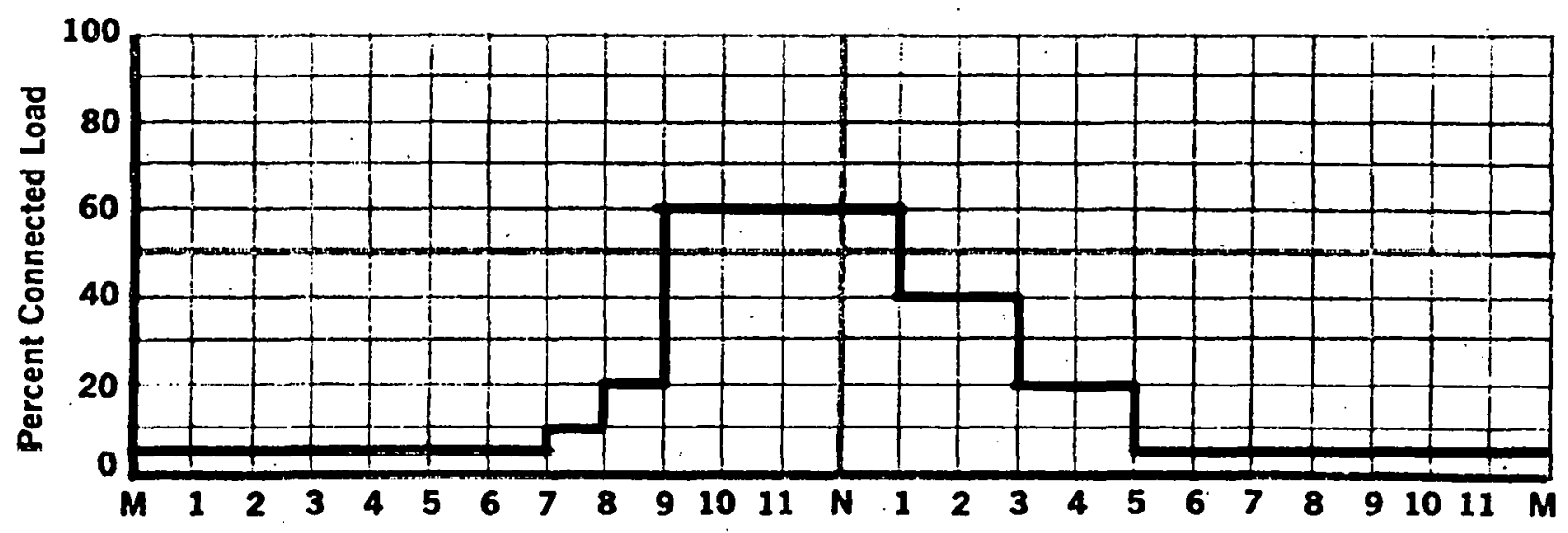



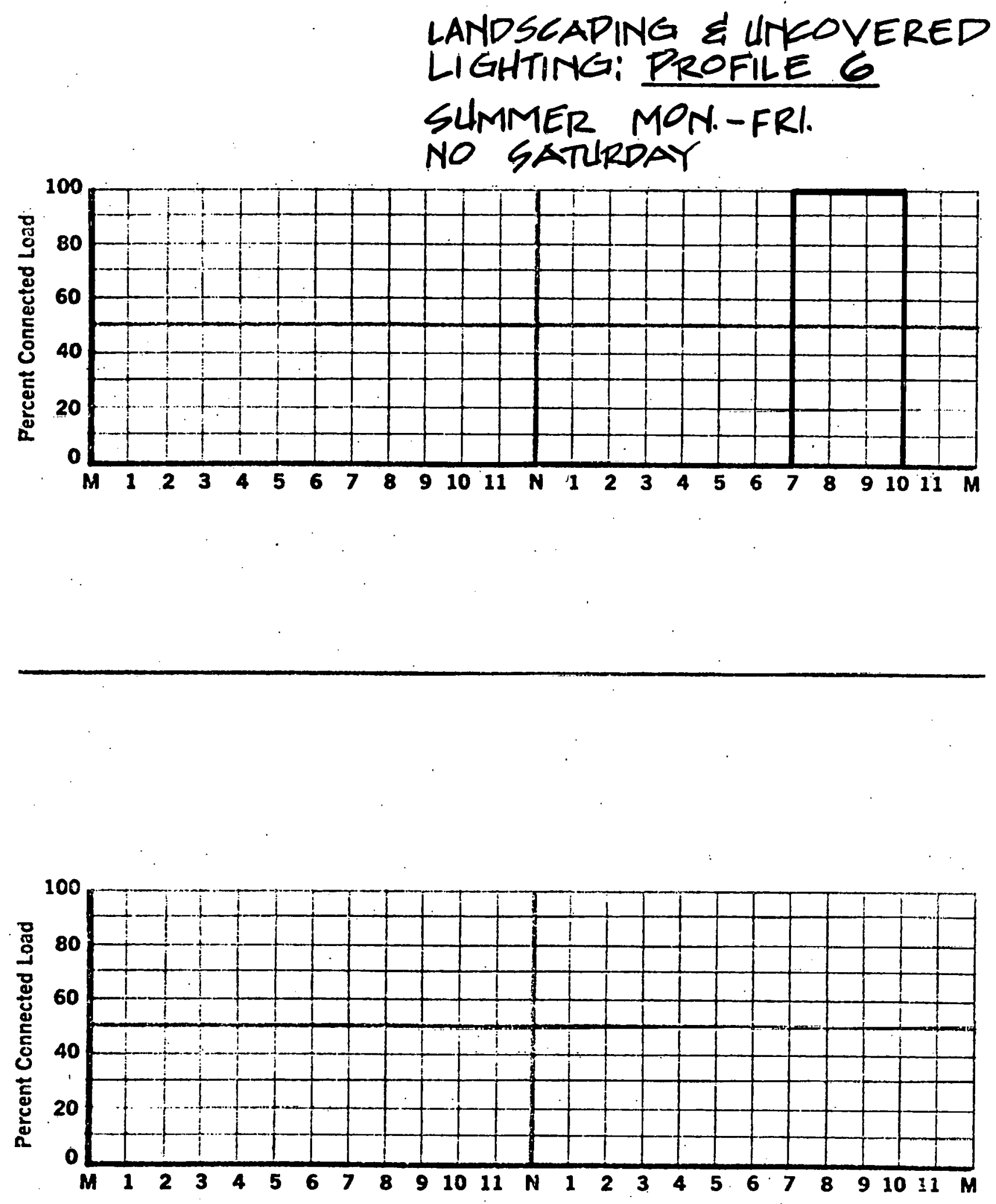
MISC. SMALL LOADS:

SHOPPING CENTER STORES: PRDFILE 7 WEEKDAY

WEEKDAY CHRISTMAS---:--

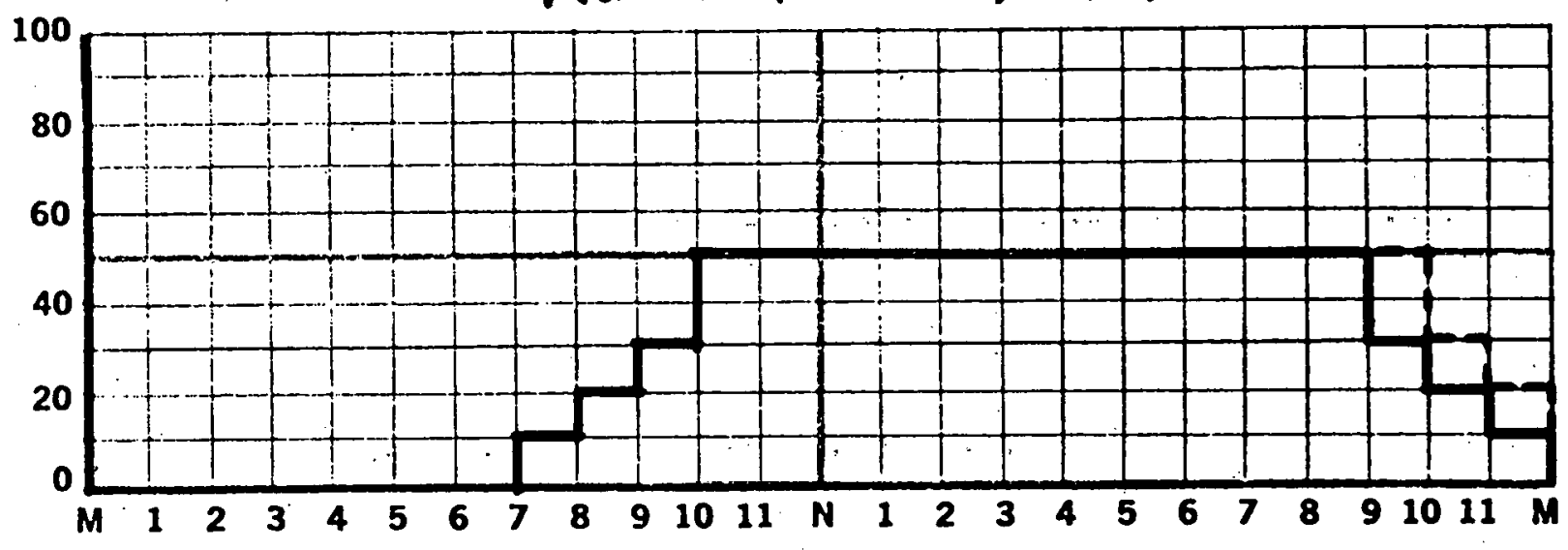

SATURDAY

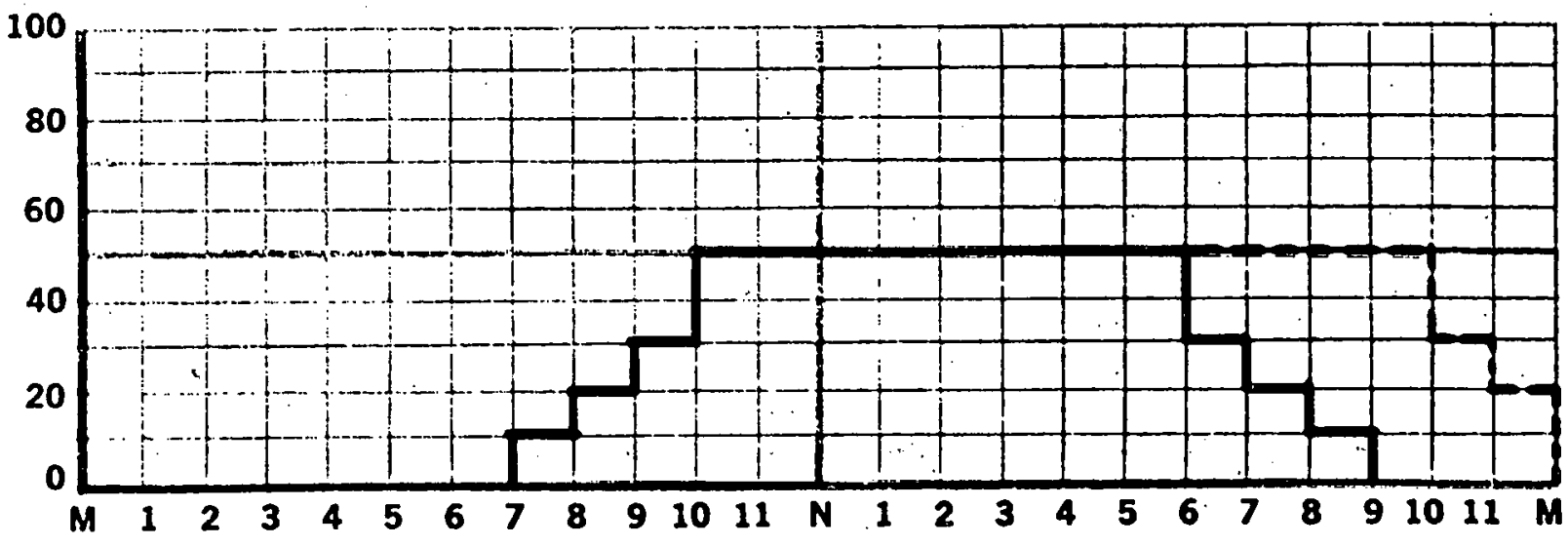



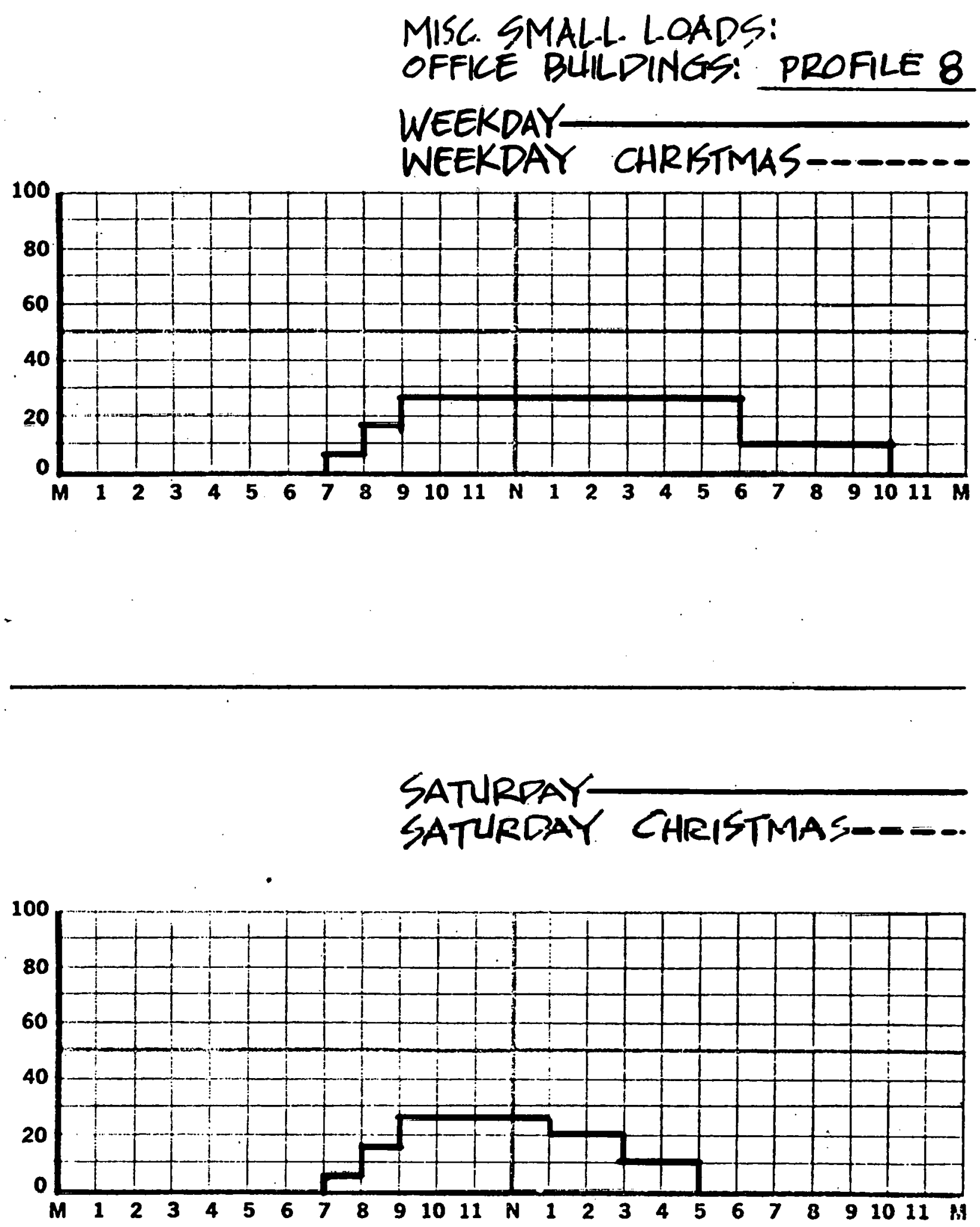
EXHALST FAN:

DEPT. STORES: PROFILE 9.

WEEKDAY WEEDAY CHRISTMAS-D--

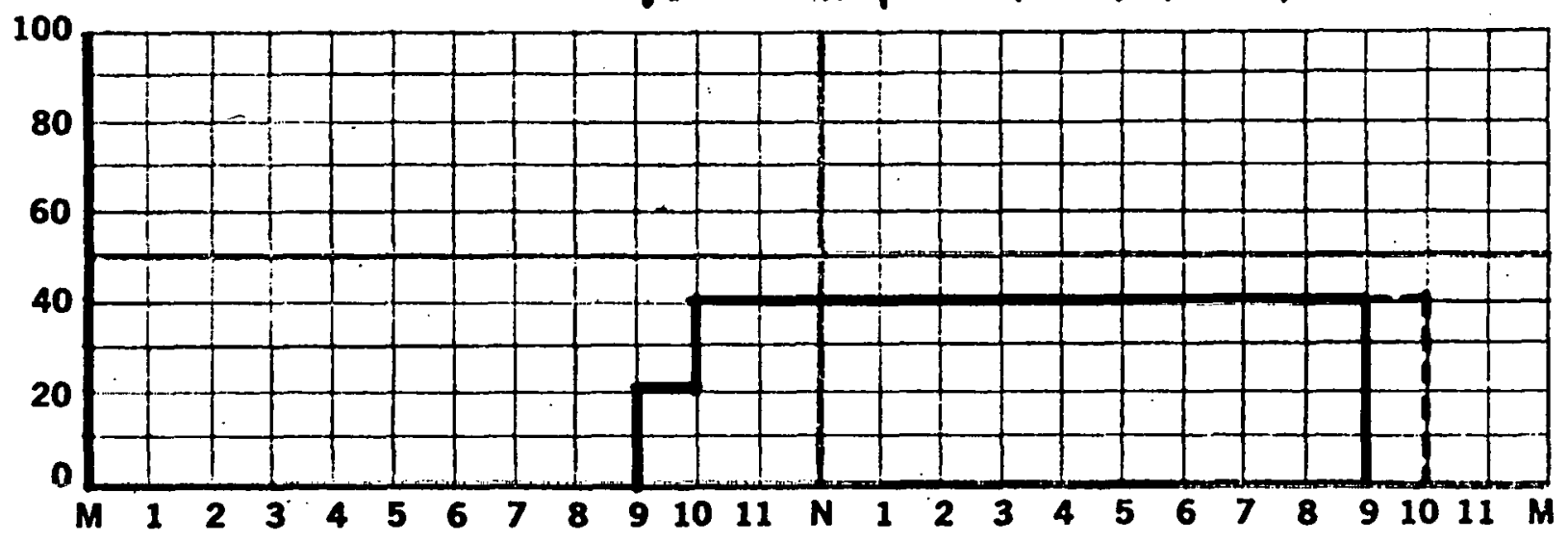

SATURDAY
SATURDAY CHRISTMAS--.-

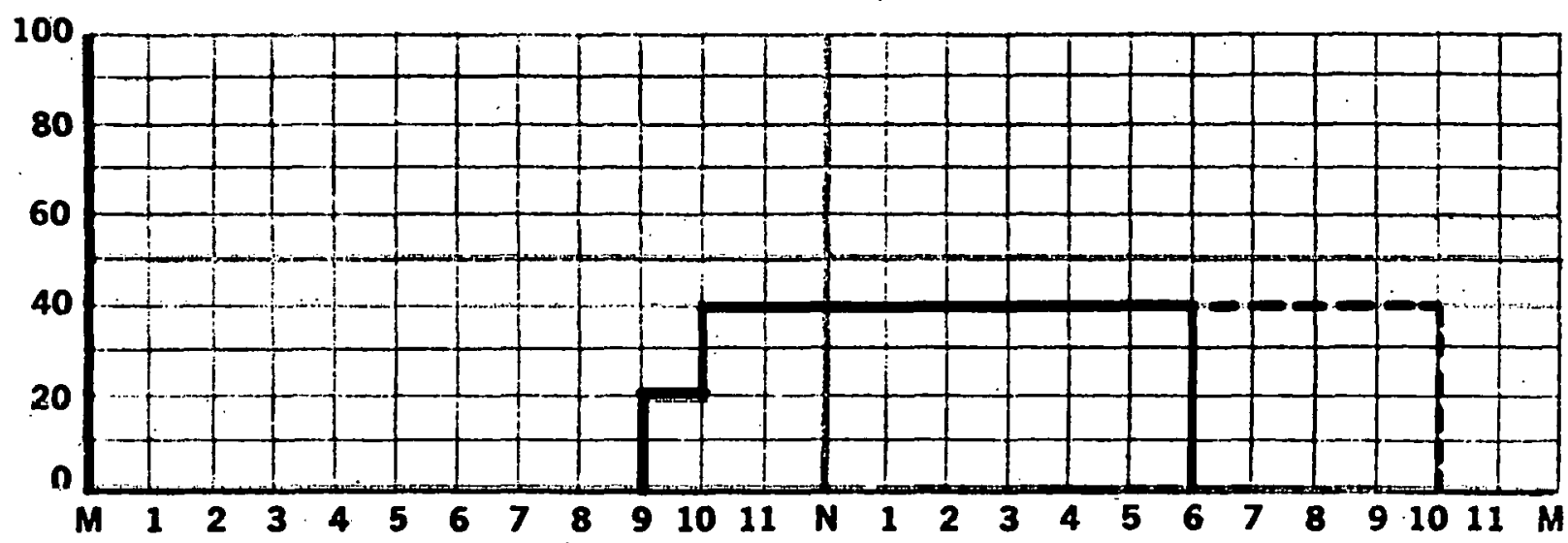


EXHAUST FANS

SHOPPING CENTER STRRES: PROFILE: 10

WEEKDAY

WEEKDAY CHRISTMAS-----

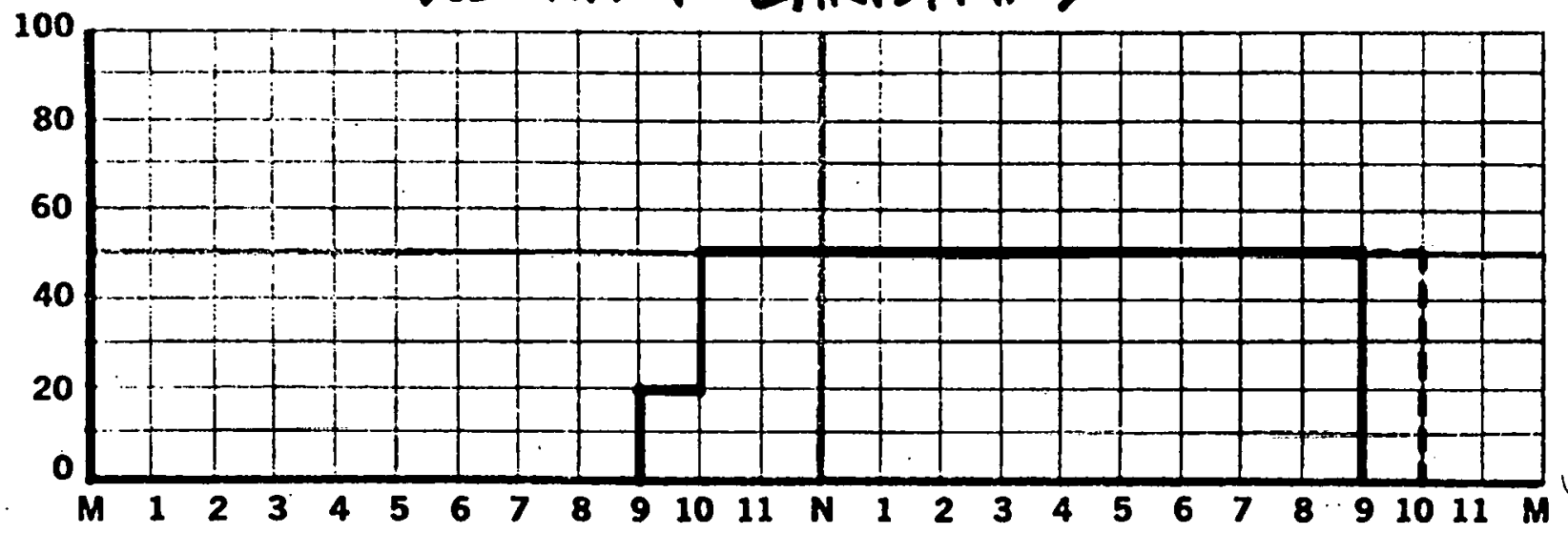

SATURDAY
SATIRPAY CHRASTMAS-D--

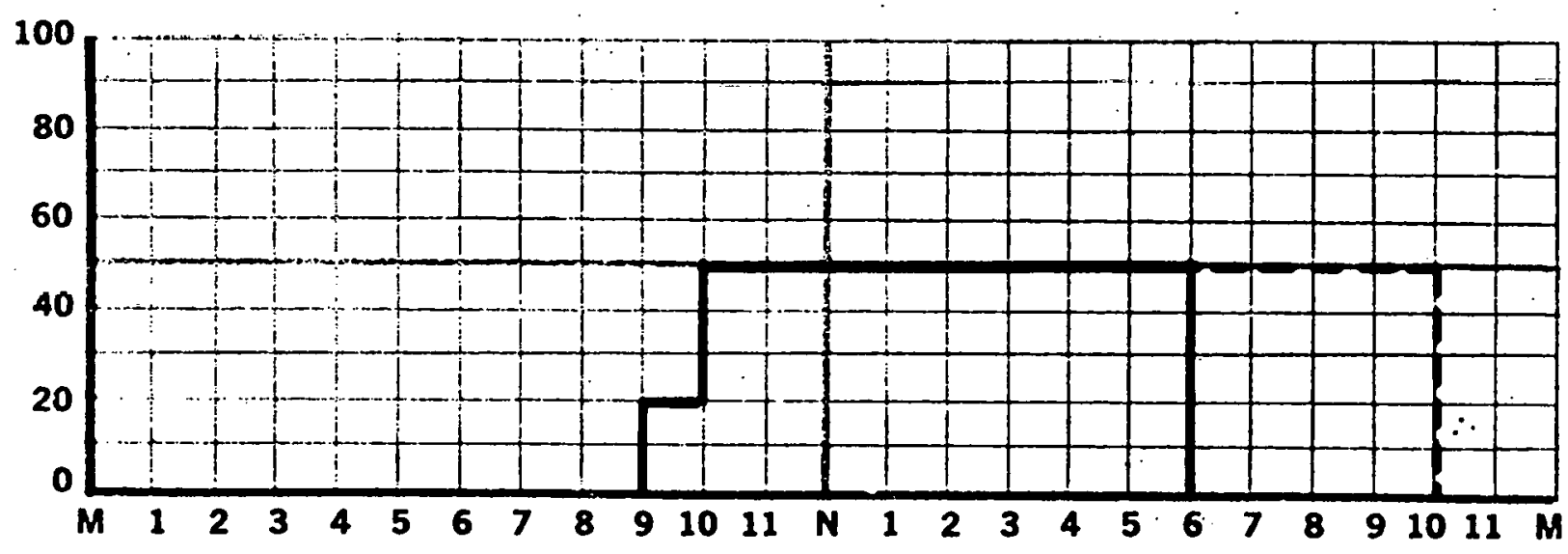


EXHALST FAN

RESTAURANT: PROFILE II

WEEKDAY

WEEKDAY CHRISTMAS-----

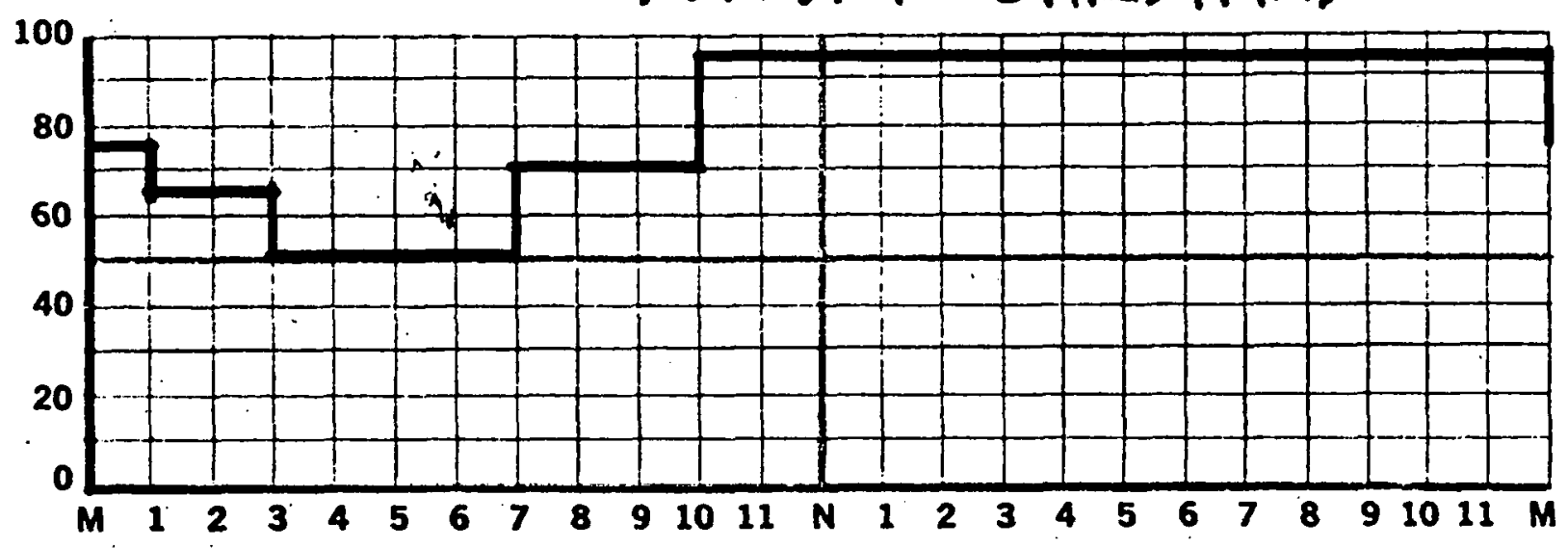

SATURDAY- CHRISTMAS----

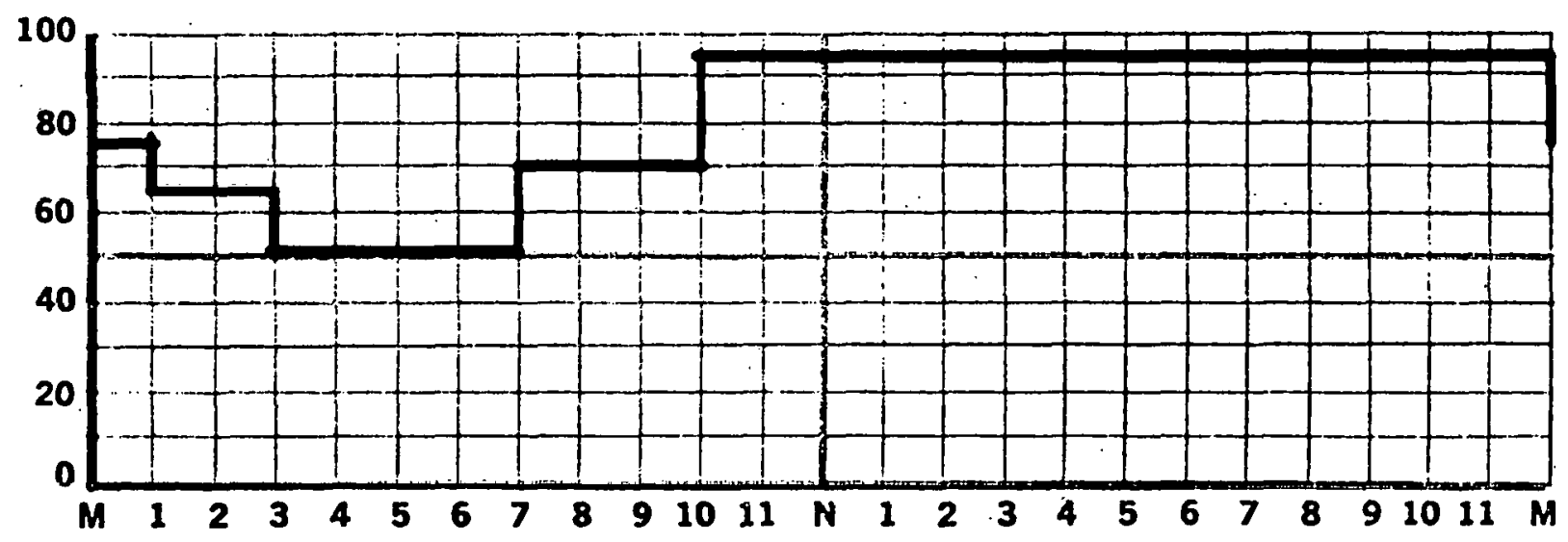


EXHALIST FANS:

OFFILE BUILDING: PROFILE IZ

WEEKDAY

WEEKDAY CHRISTMAS-----

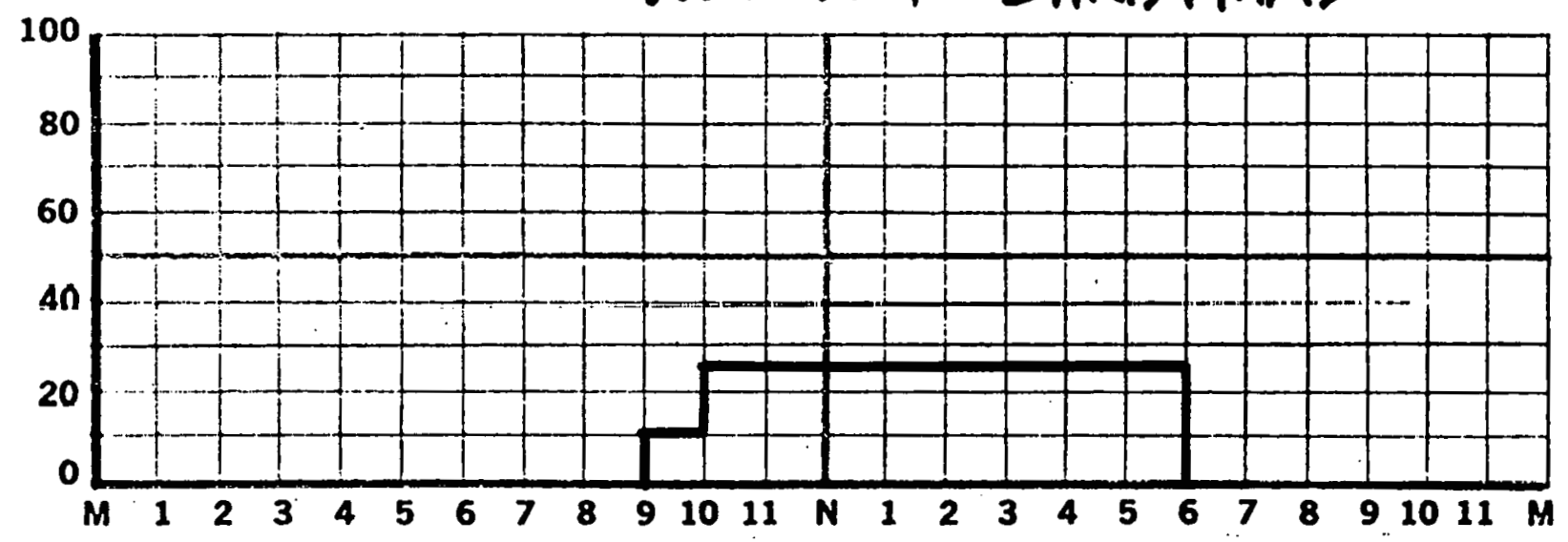

SATURPAY
SATURDAY CHRISTMAS---:-

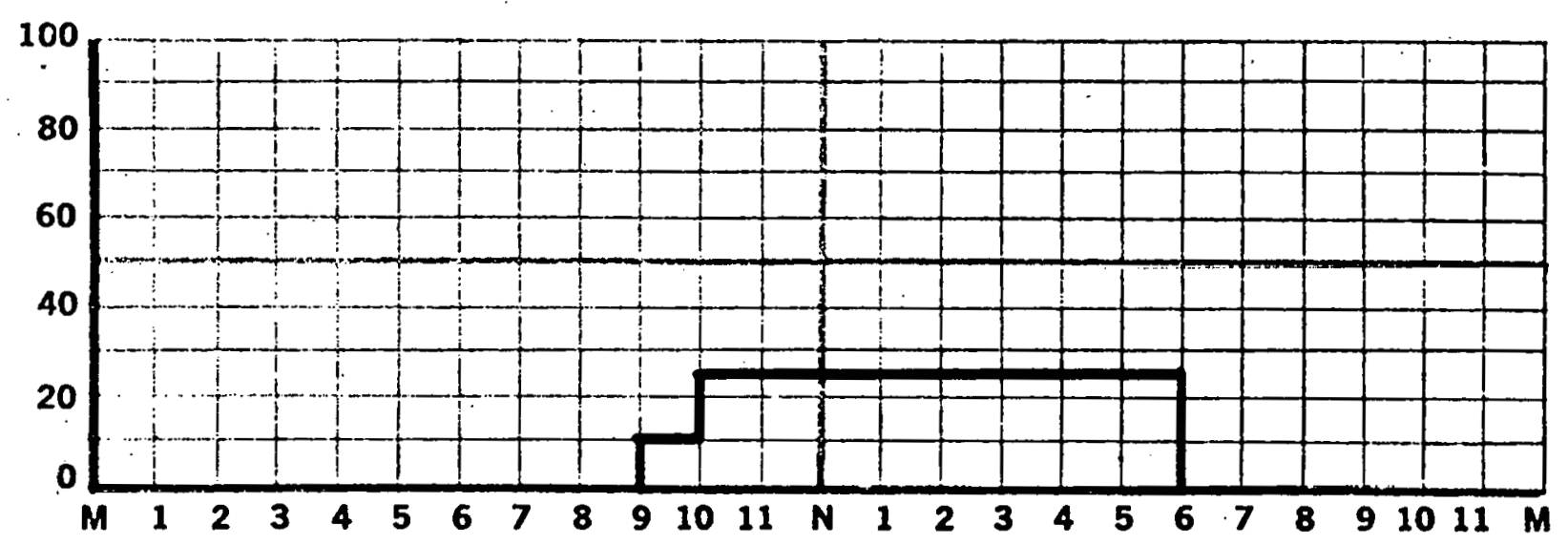


VERTILAL TRANSPORTATIONY:

DEPT. STORES \& MALLS \&

CORRIPORS: PROFILE I3 WEERDAY PRZ WEERDAY CHRISTMAS-

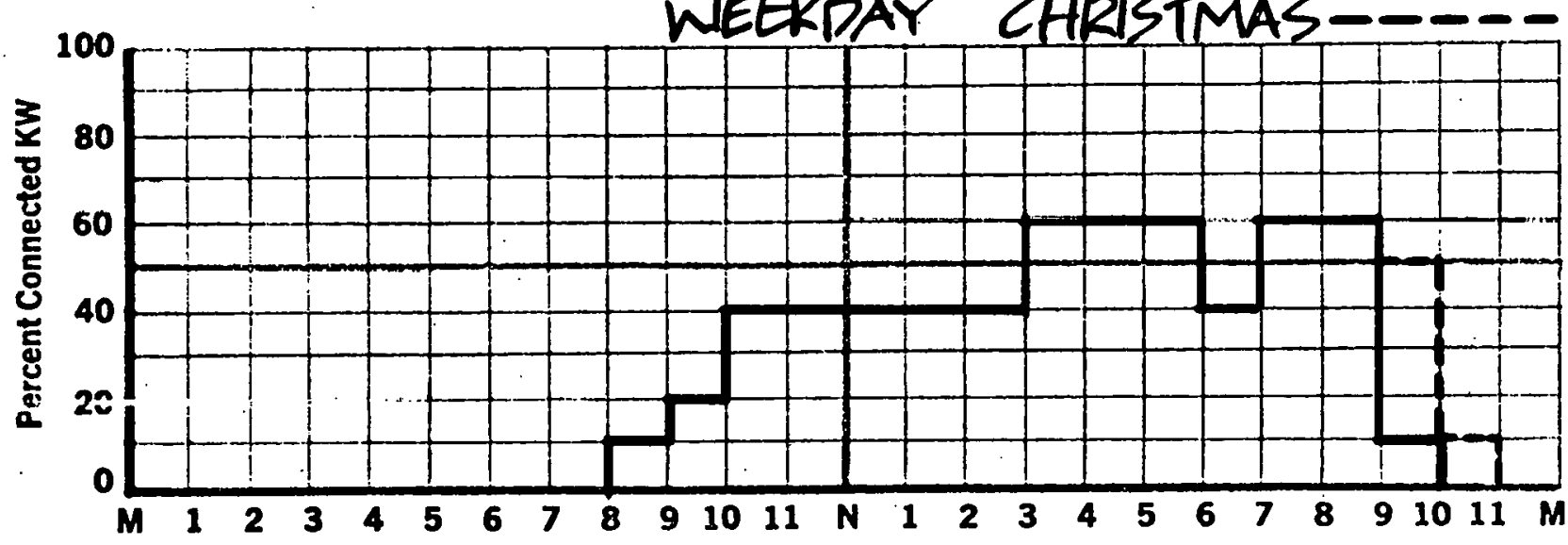

SATURDAY SATURDAY CHRISTMAS---.

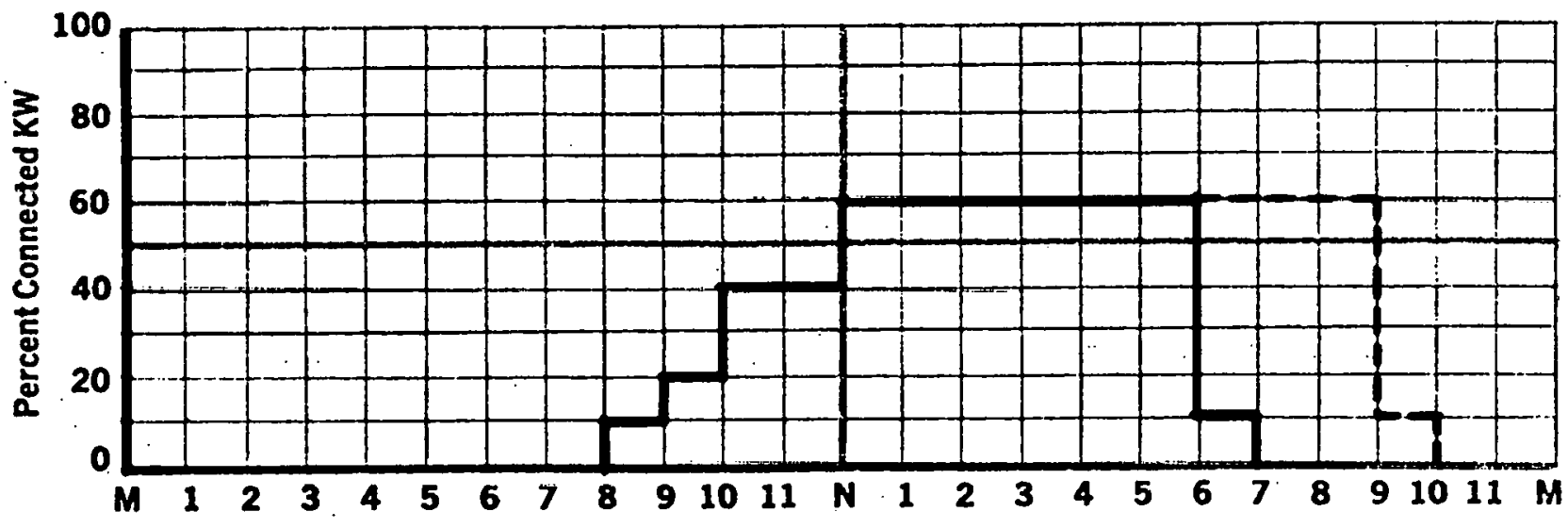

D-15 
VERTILAL TRANSPORTATION:

OFFILE BUILDINGS: PROFILE IA

WEEKDAY WEEKDAY CHRISTMAS-----

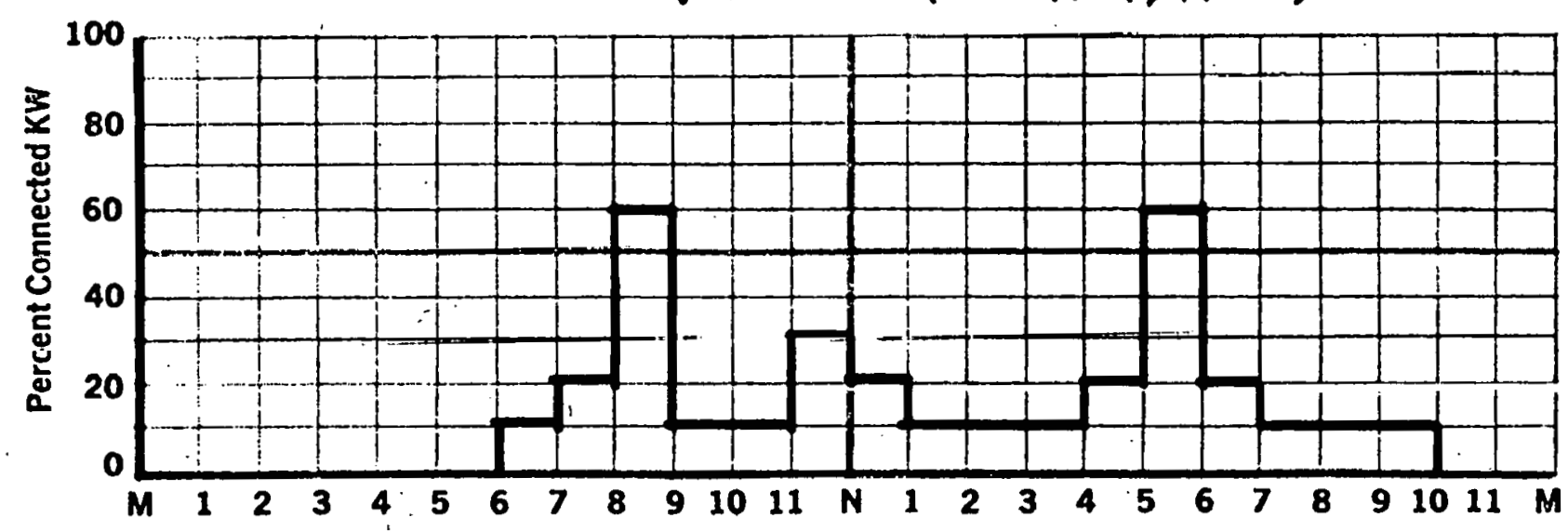

SATURDAY

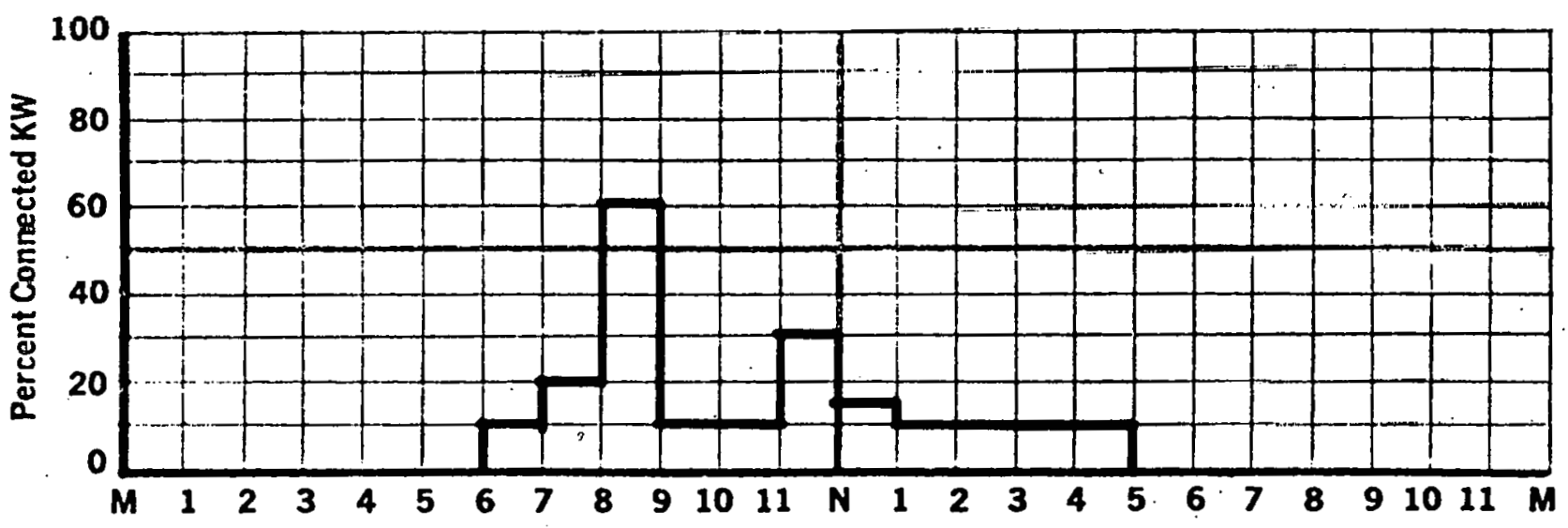



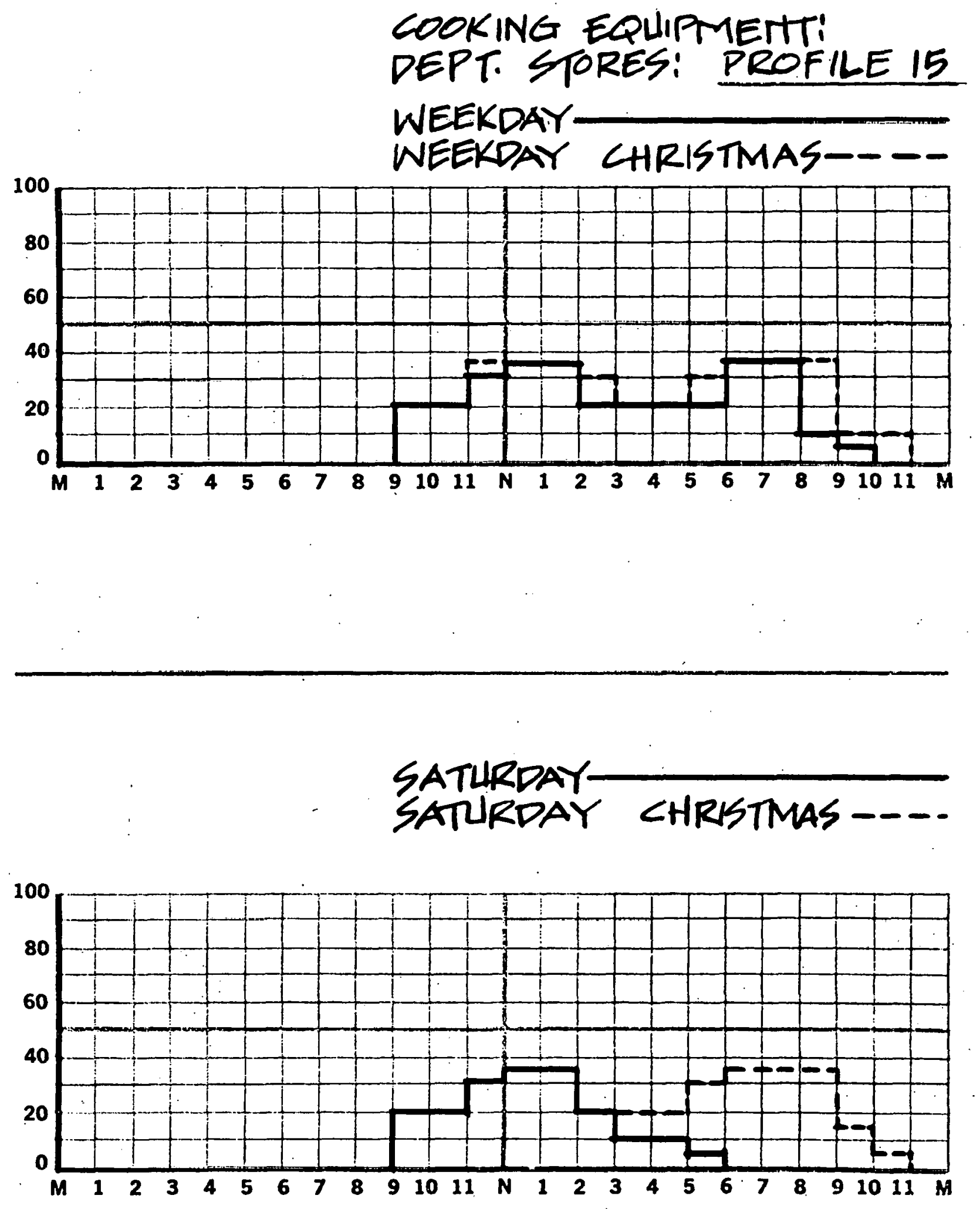
COOKING EQLIPMENT: RESTAURANT: PROFILE IG

WEEKDAY

WEEKDAY CHRISTMAS - -.--

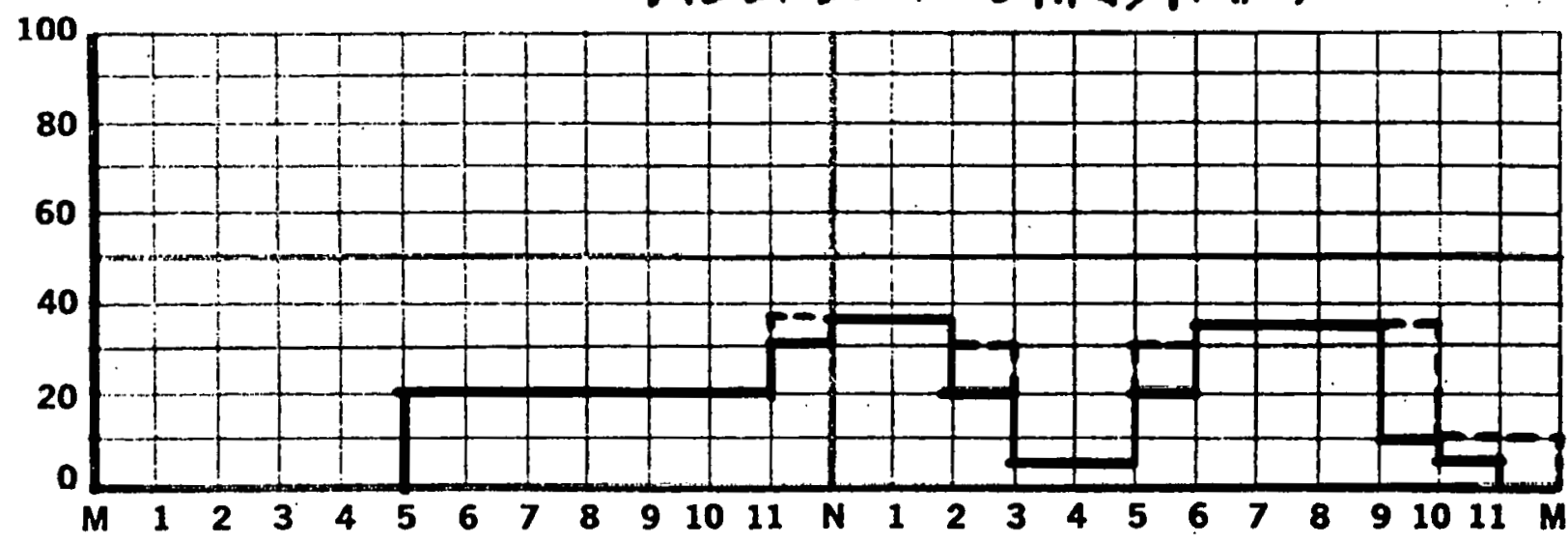

SATURDAY
SATURDAY CHRISTMAS----

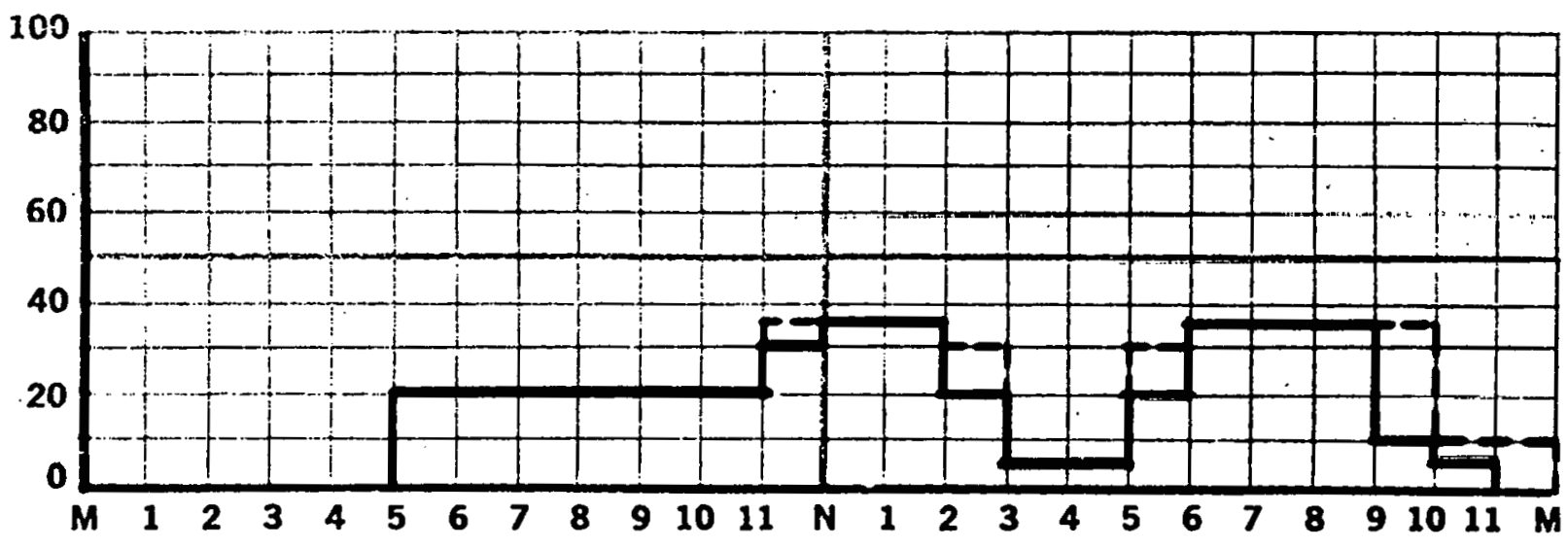


DOMESTIC WATER HEATING: DEPT. STORES: PROFILE 17 WEEKDAY

WEEKDAY CHRISTMAS----

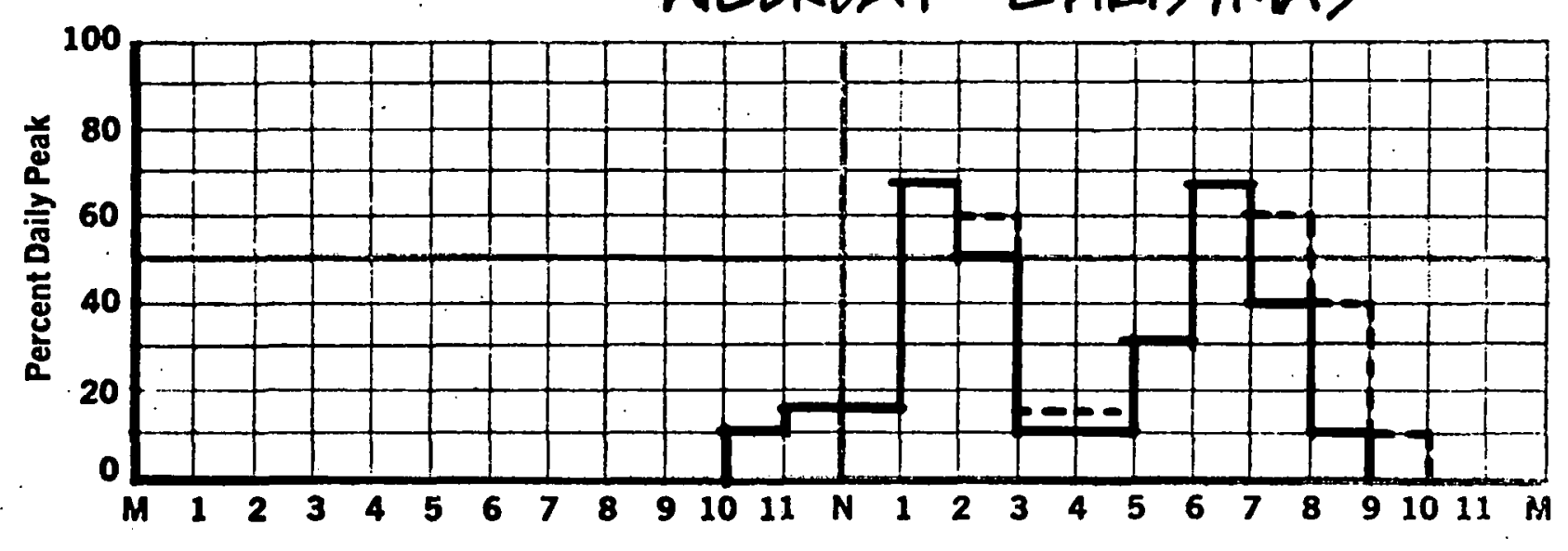

SATURDAY CHRISTMAS-D--

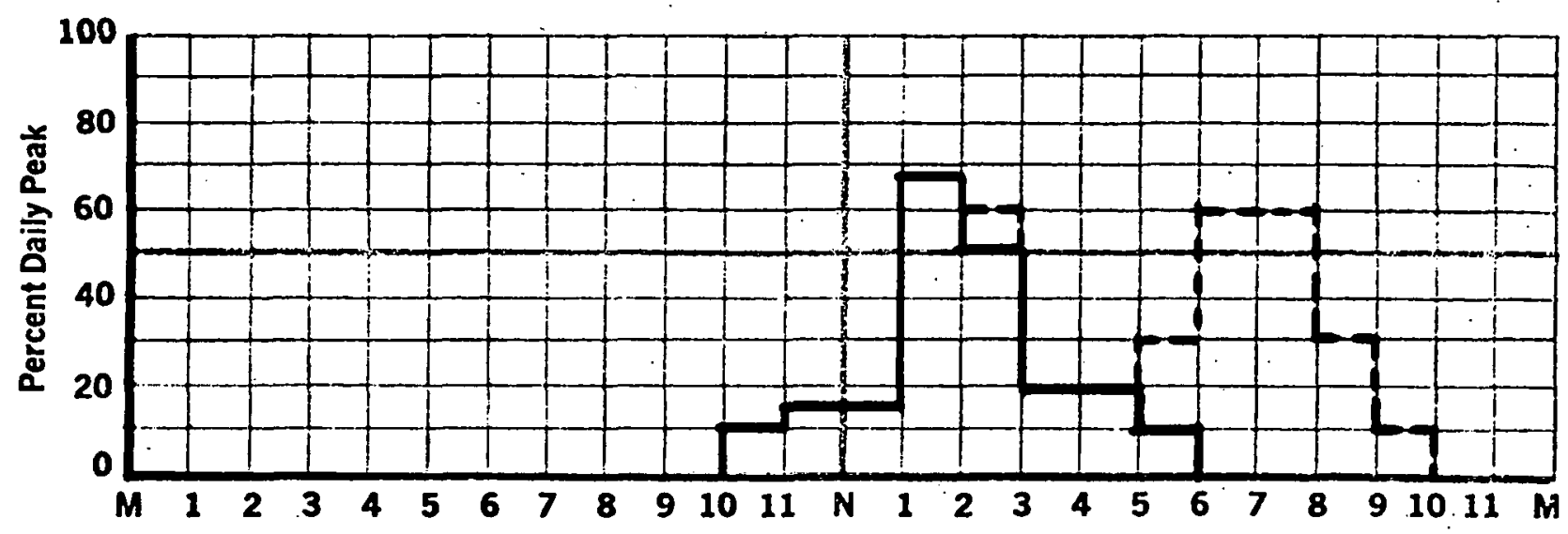

D-19 


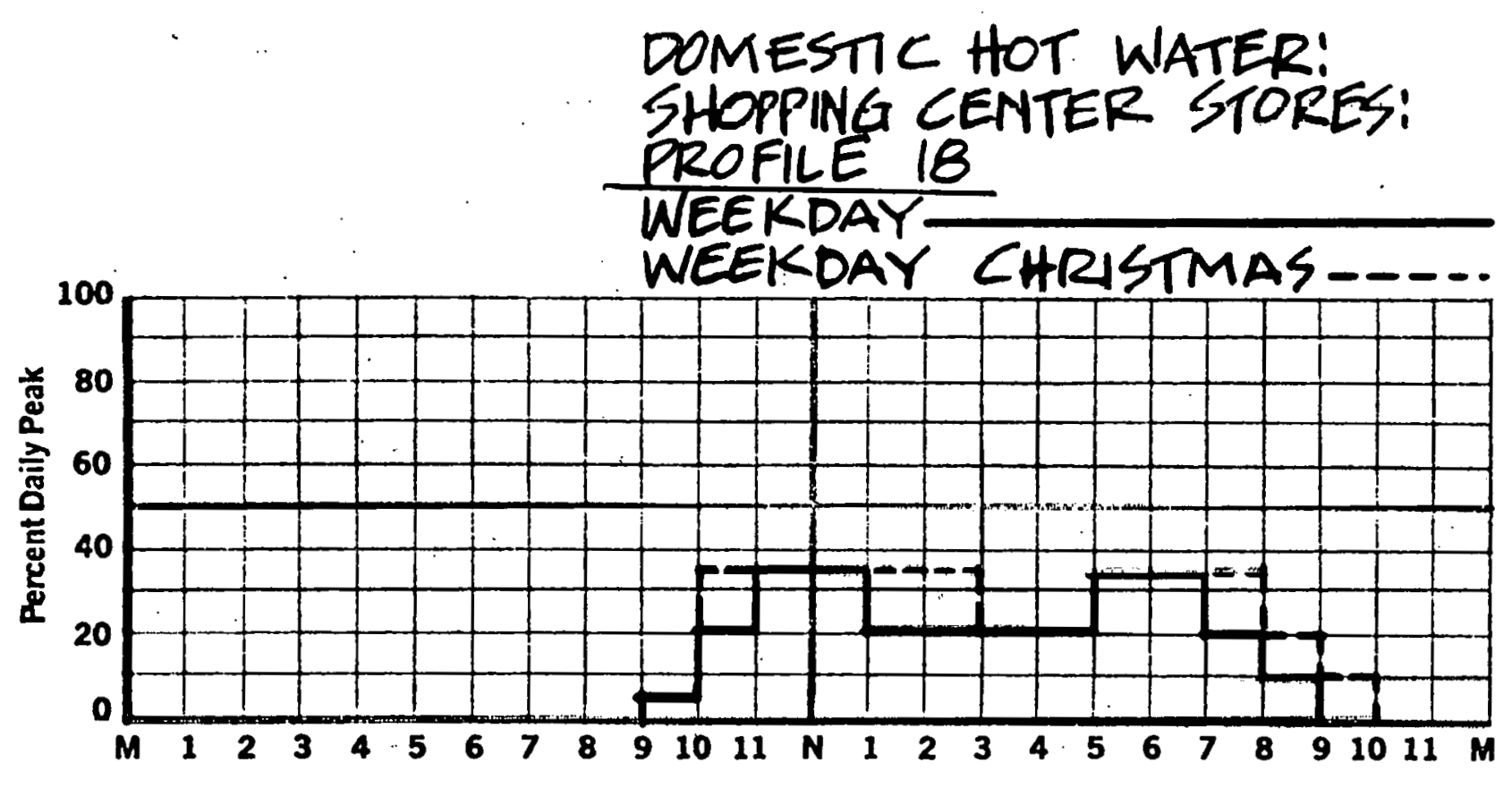

SATRRDAY CHRISTMAS-:--

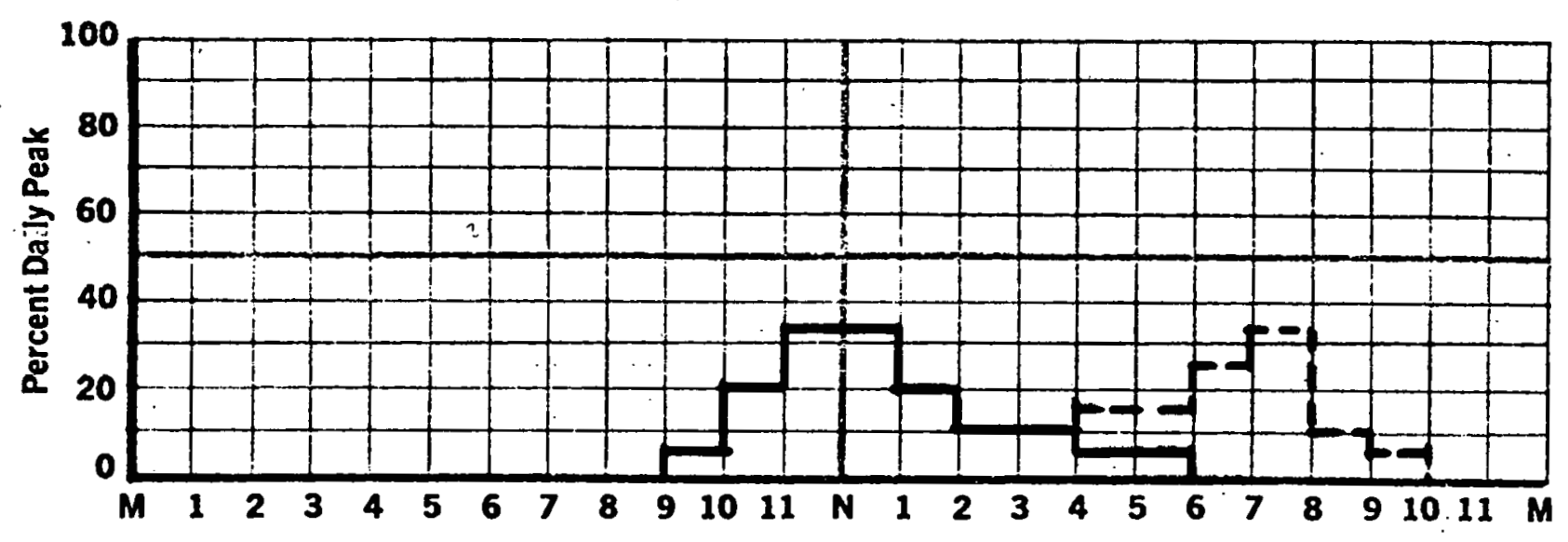


DOMESTC HOT WATER:

RESTALRANTS: PROFILE 19

WEEKDAY

WEEKDAY

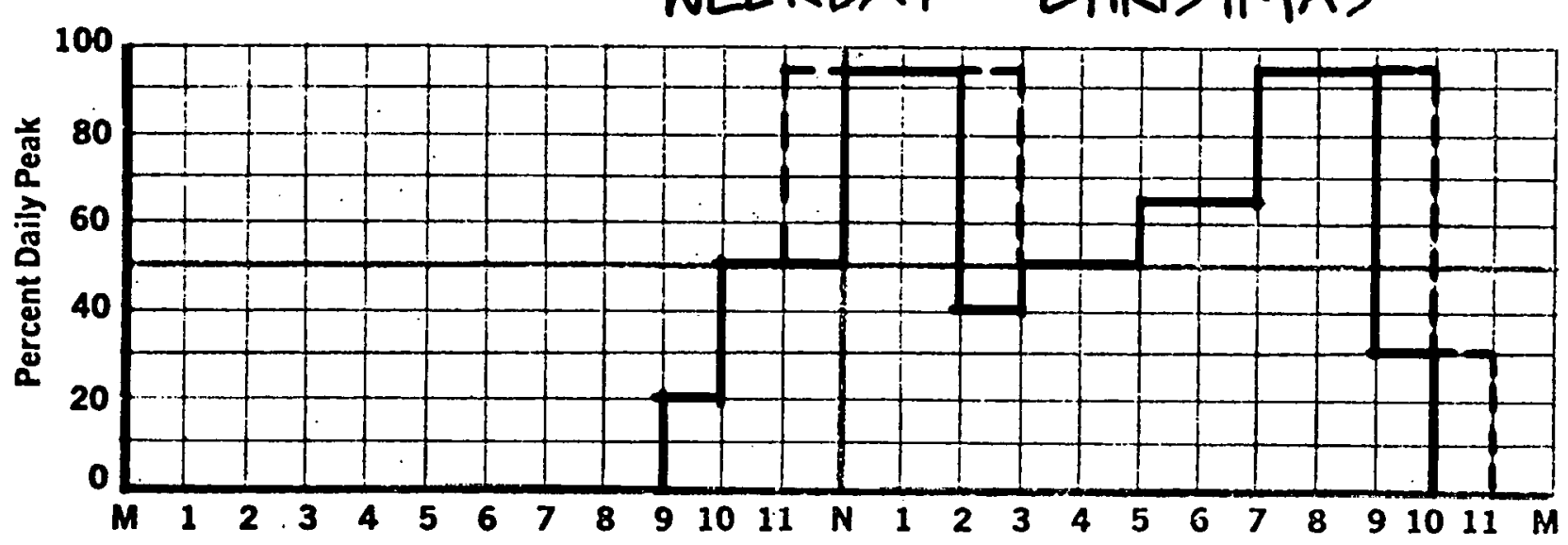

SATURDAY
SATURDAY CHRISTMAS---

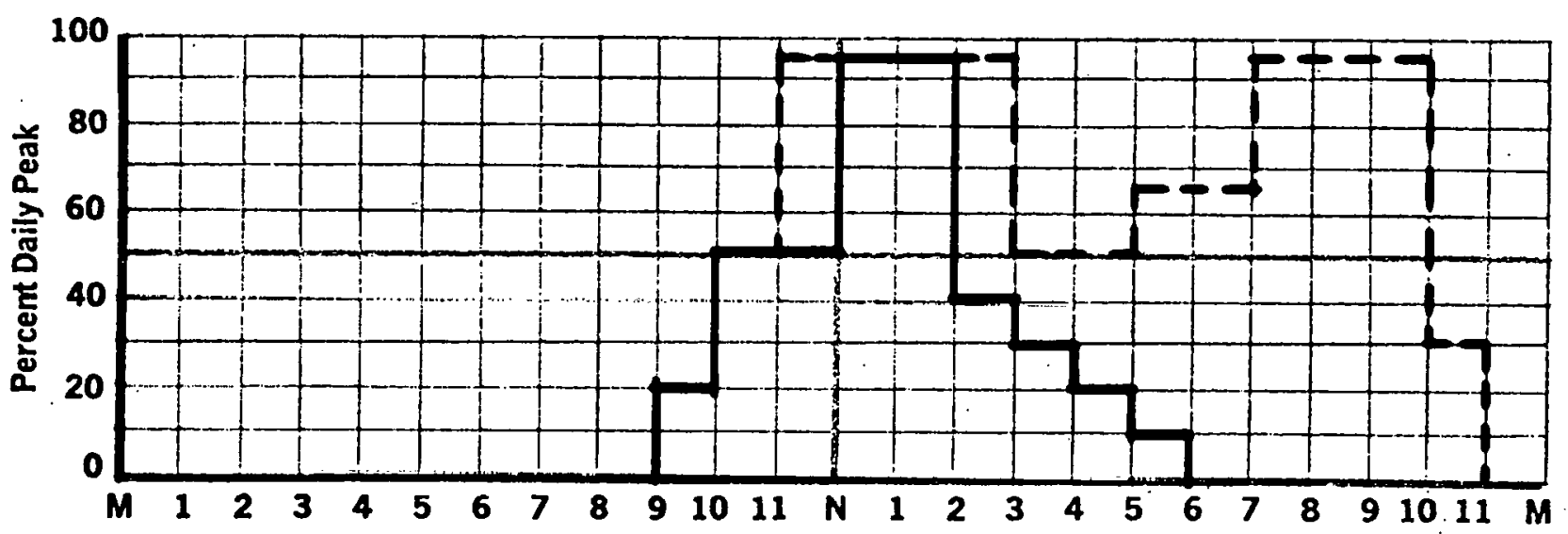


DOMESTK HOT WATER

OFFICE BLILDING: PROFILE 20

WEEKDAY

WEEKDAY CHRISTMAS ----:

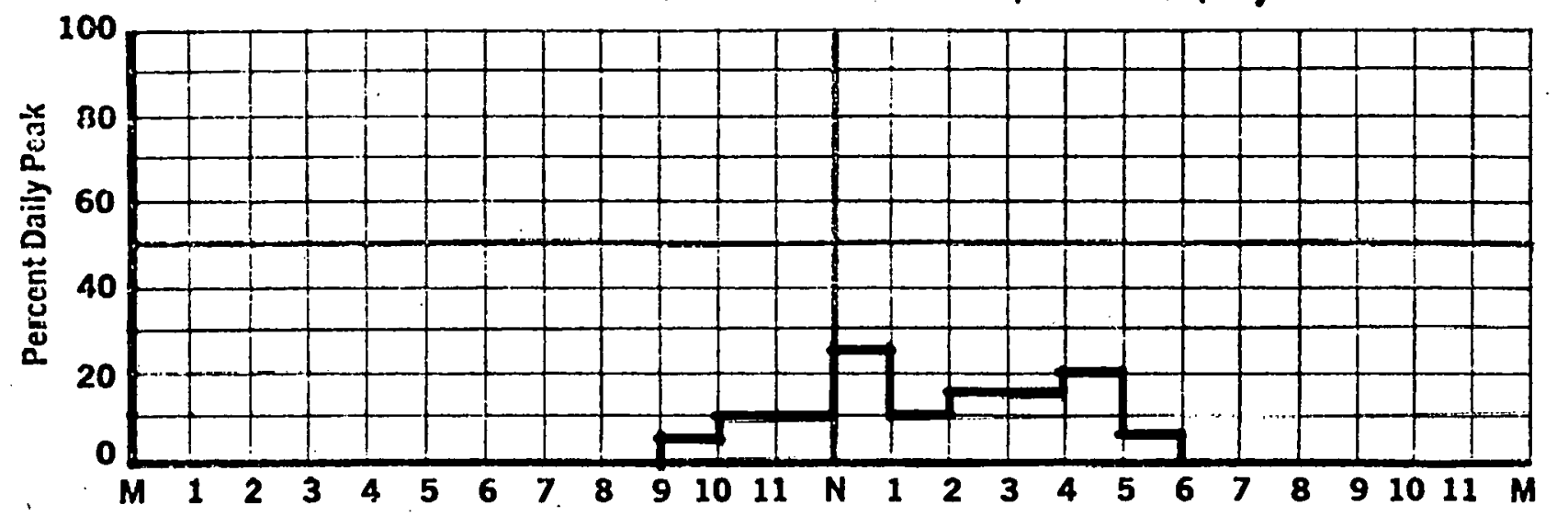

SATURDAY

SATURDAY CARISTMAS---.-

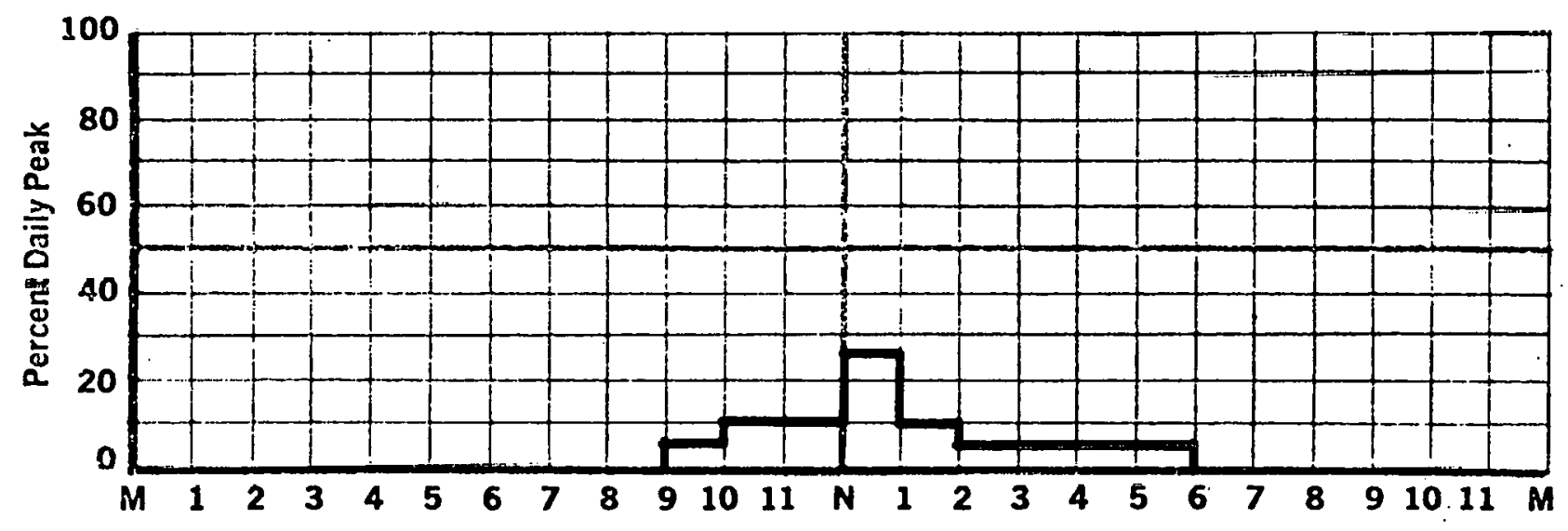


TAILOR SHOP EQLIPMENT.

DEPT STORES: PROFILE 21.

WEEKDAY

WEEKDAY CHRISTMAS----

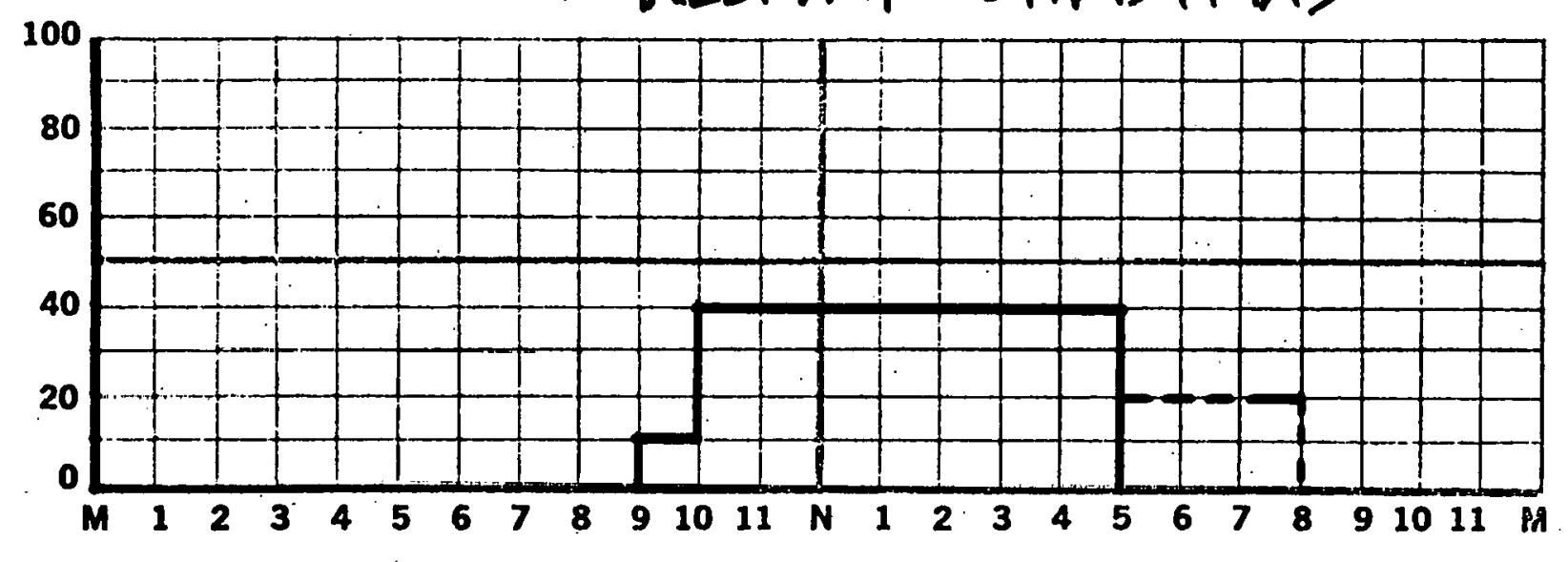

SATURDAY
SATURDAY CHRISTMAS----:

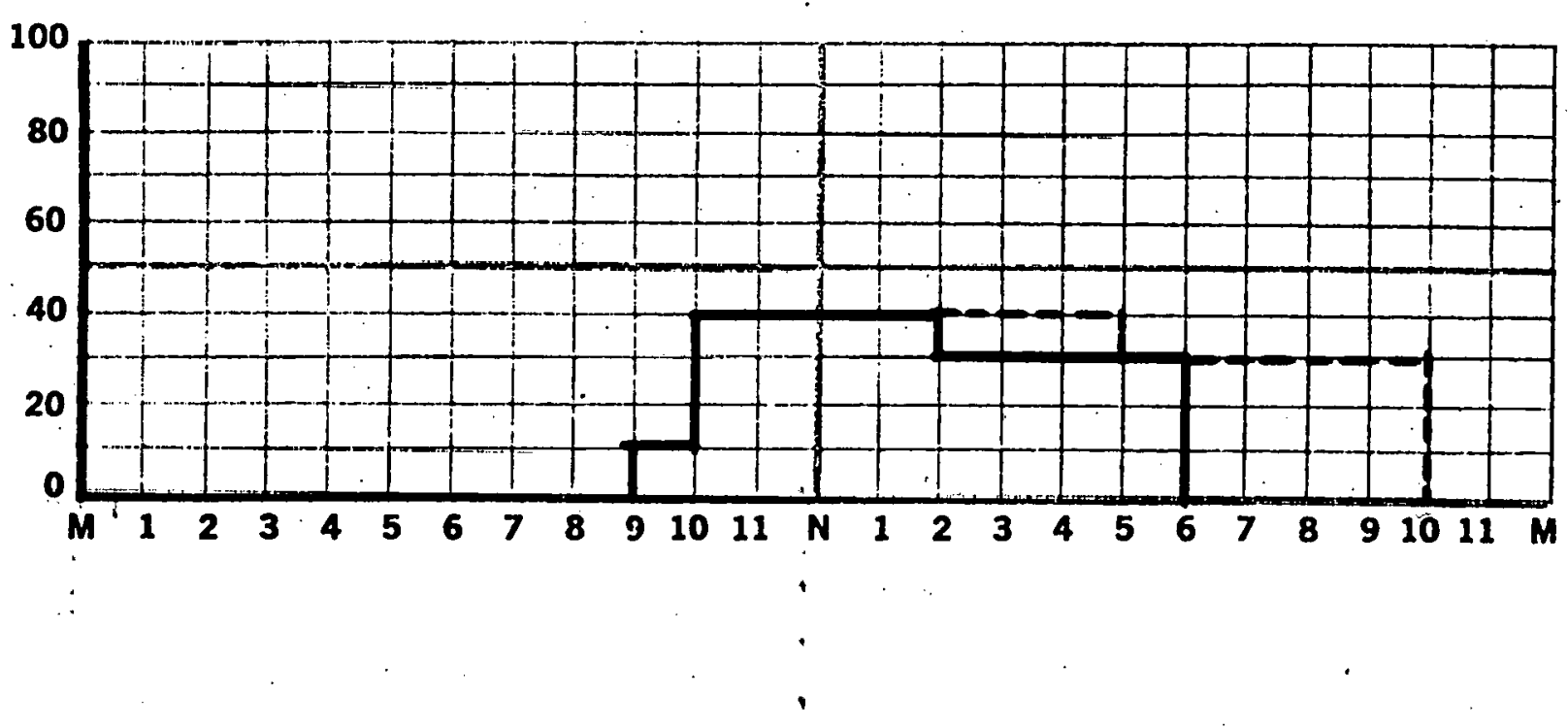

D.23 
LIGHTS \& PARKING EXHALST FANS:

COVERED PARKING: PROALE 22 WEEKDAY

WEEKDAY CHRISTMAS-- -

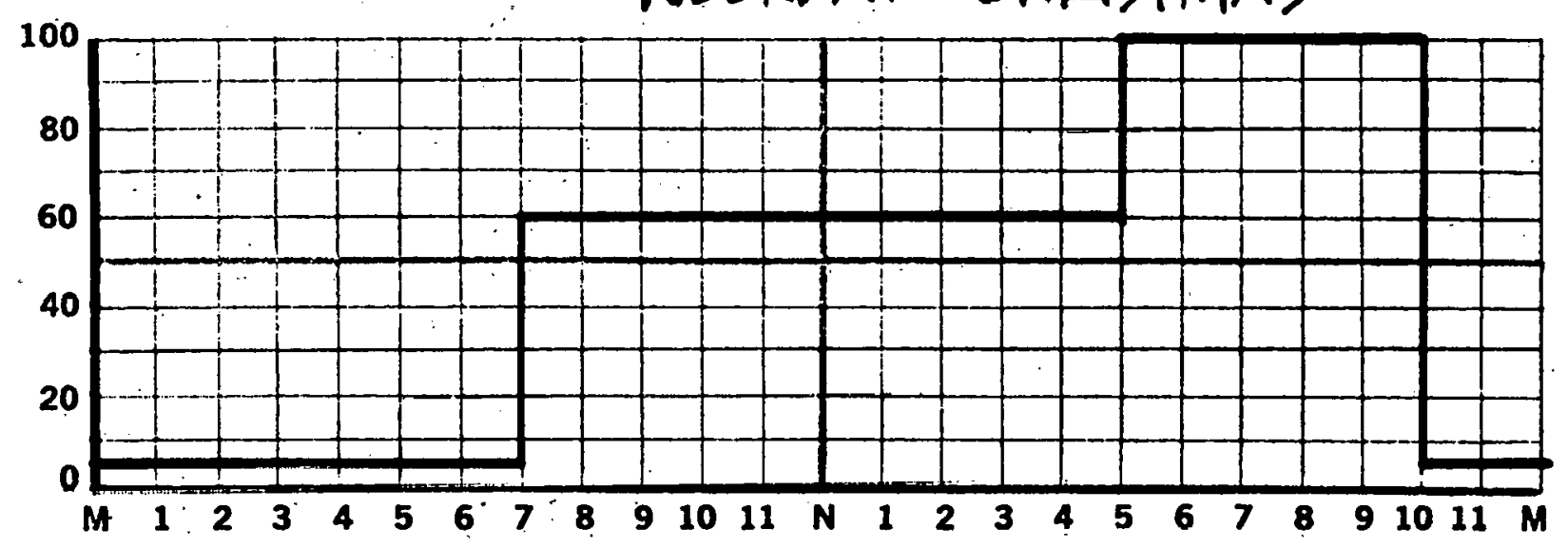

SATURDAY
SATLRDAY CHRISTMAS--

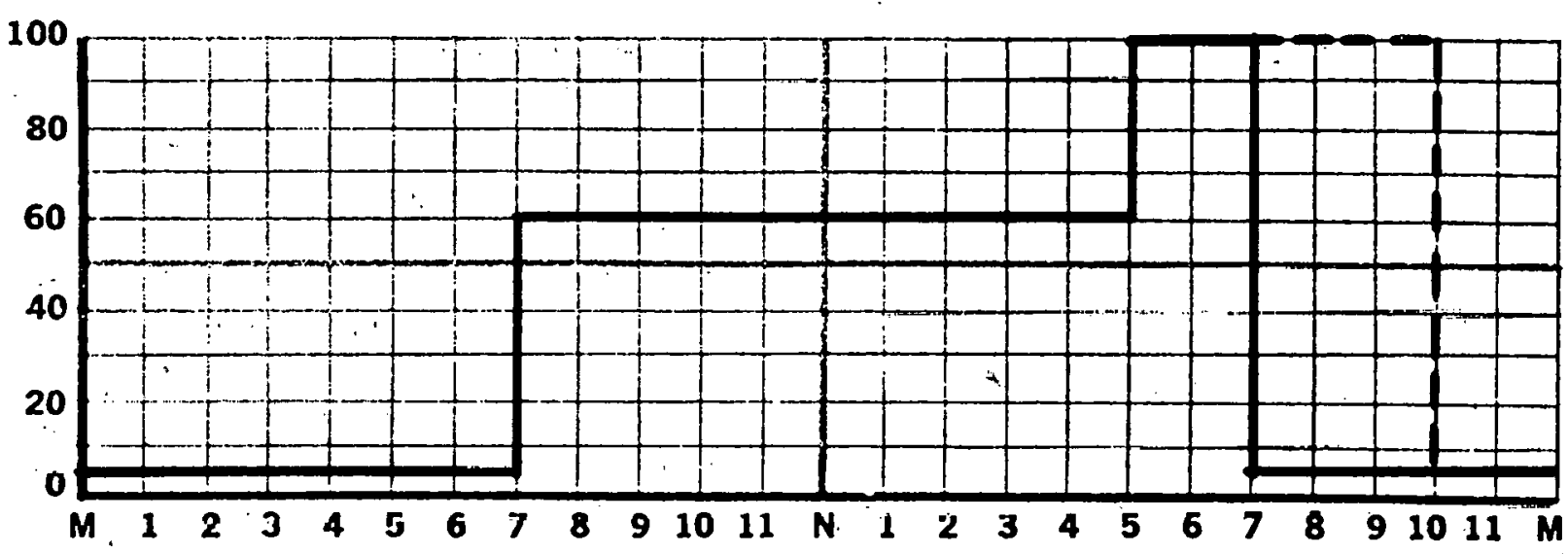




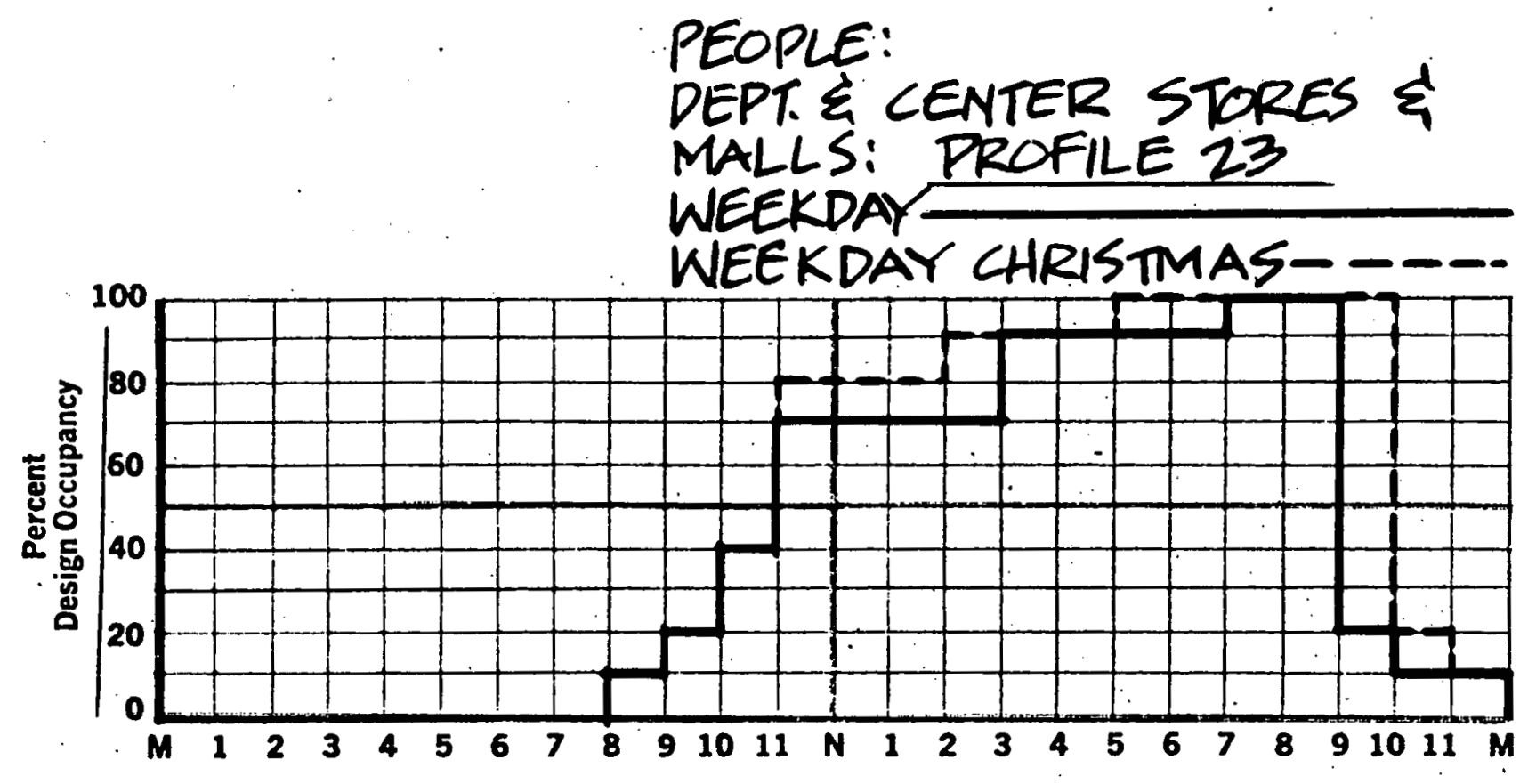

SATURDAY
SATURDAY CHRISTMAS---

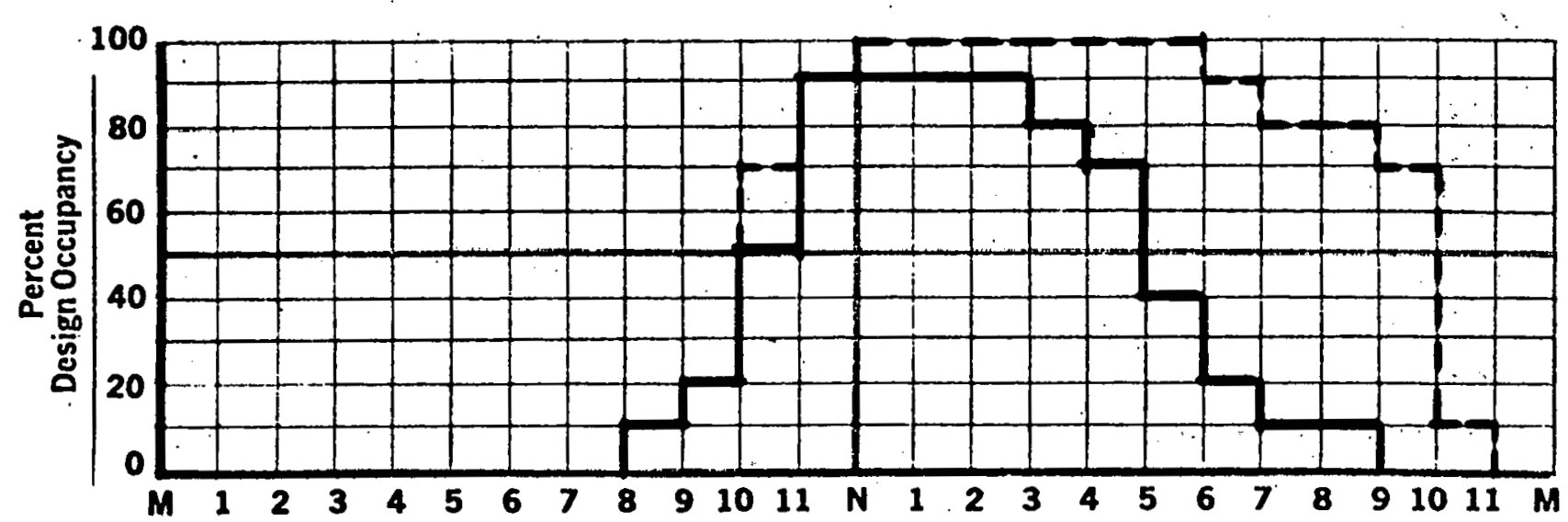




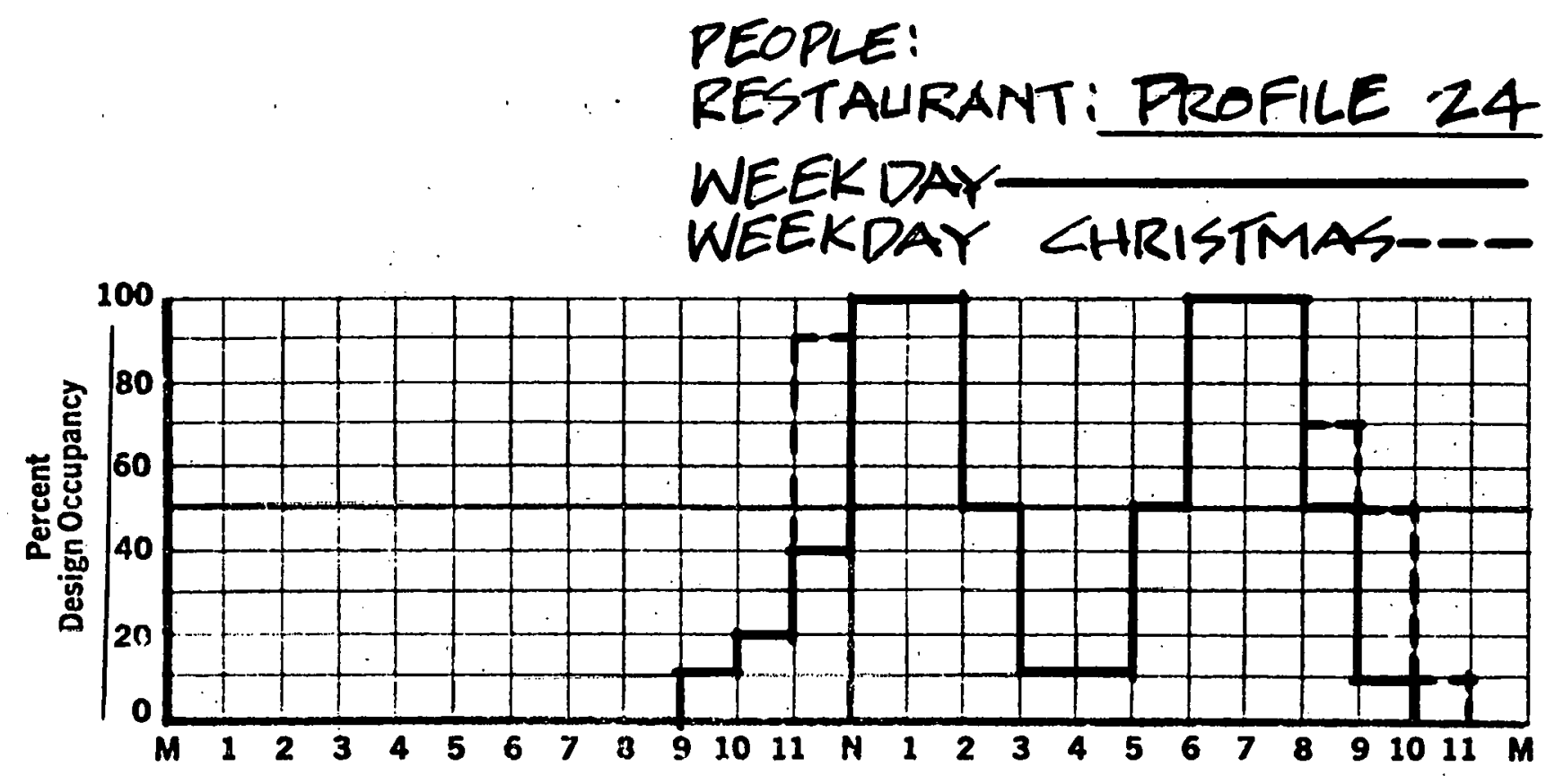

\section{SATURDAY CHRISTMAS---}

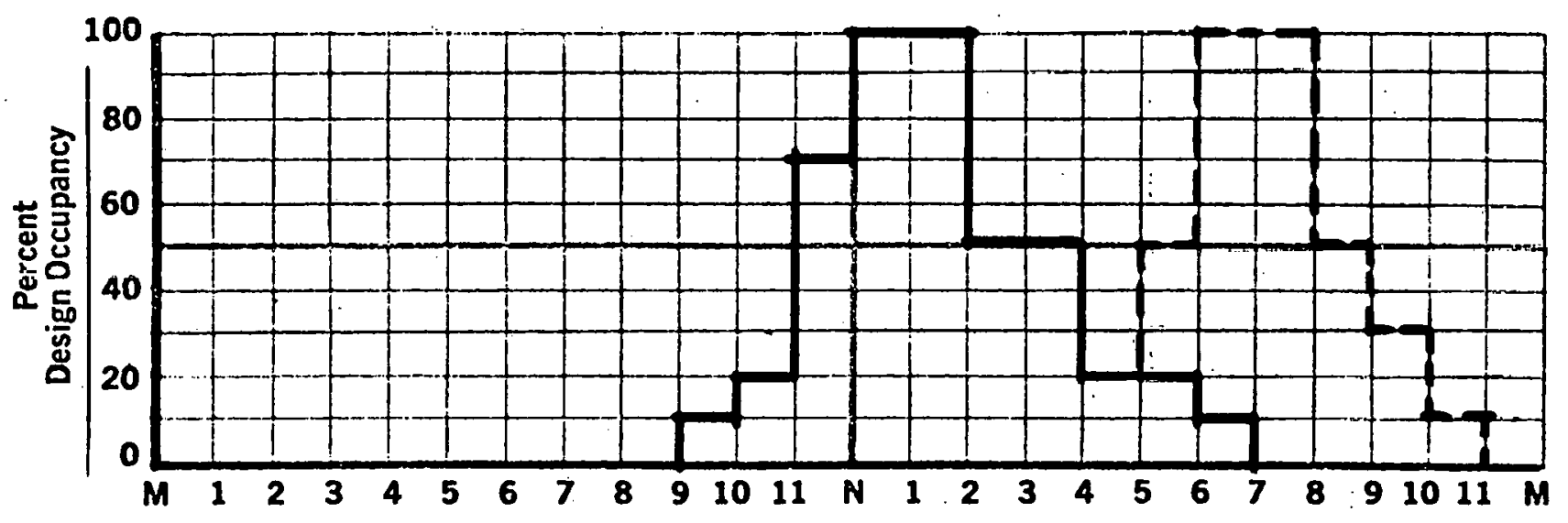




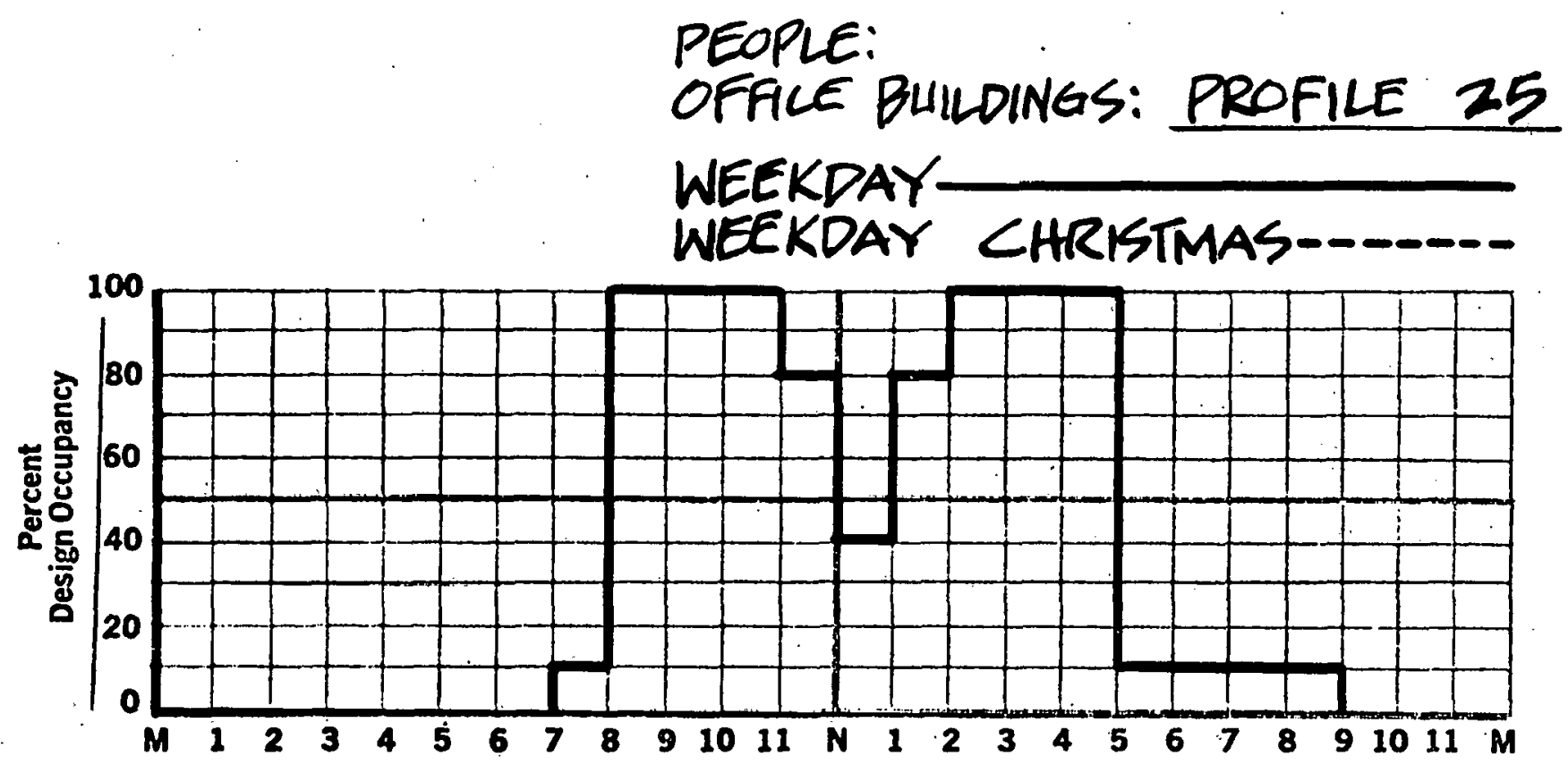

SATURDAY
SATURDAY CHRISTMAS-..-.-

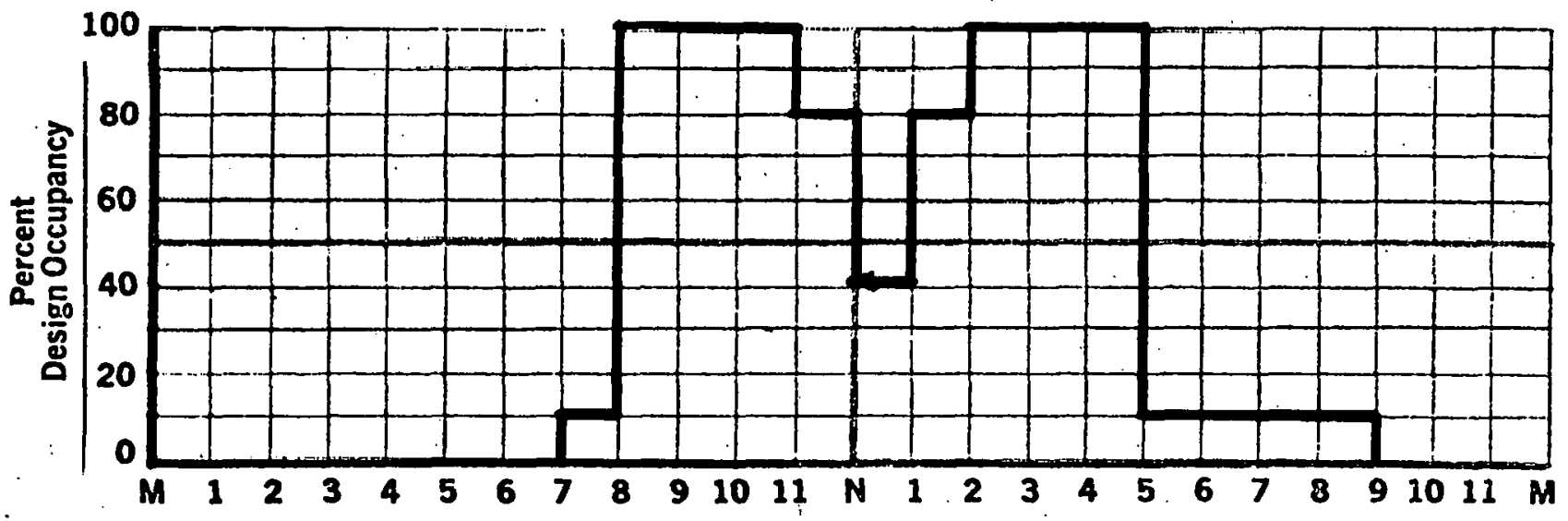



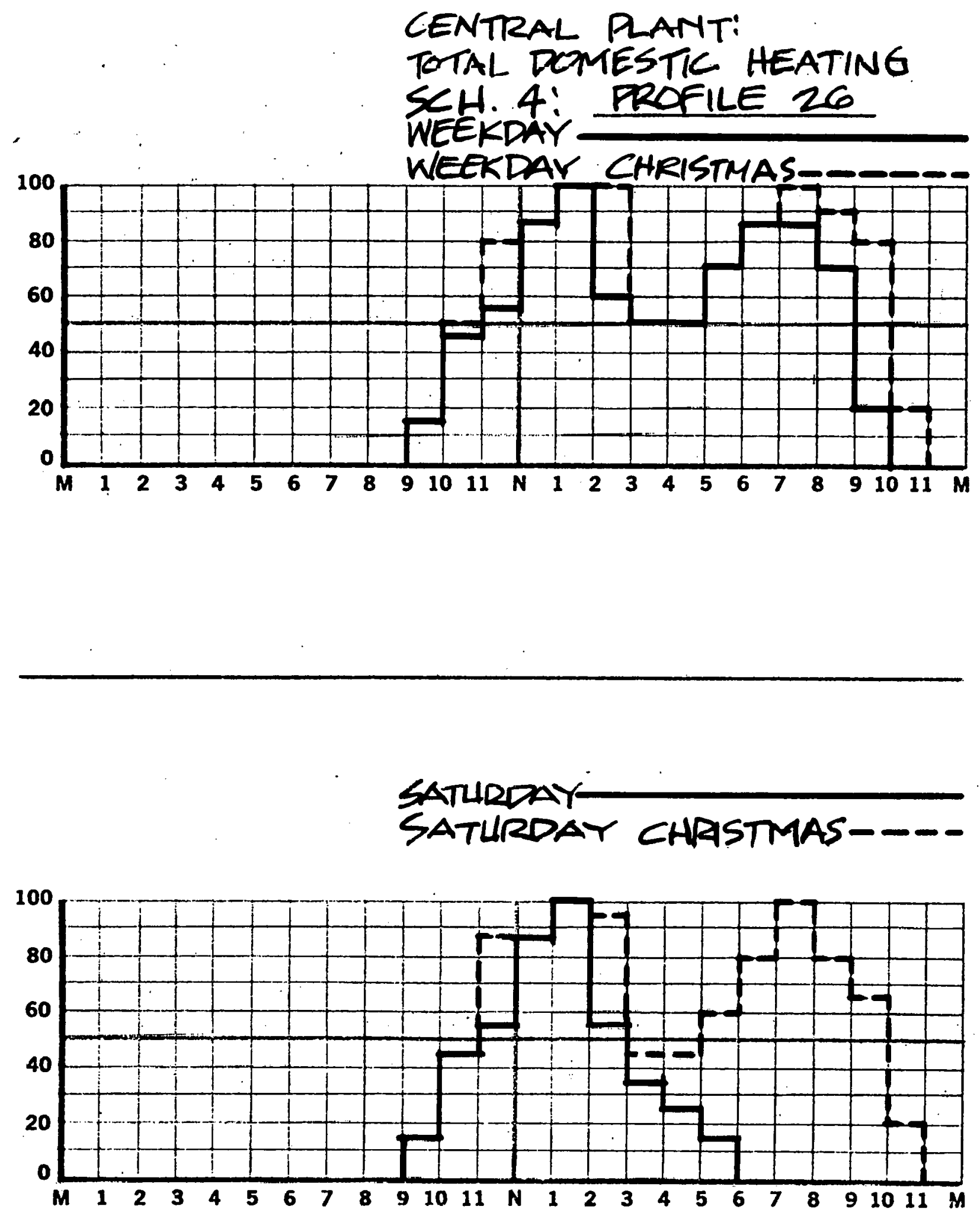


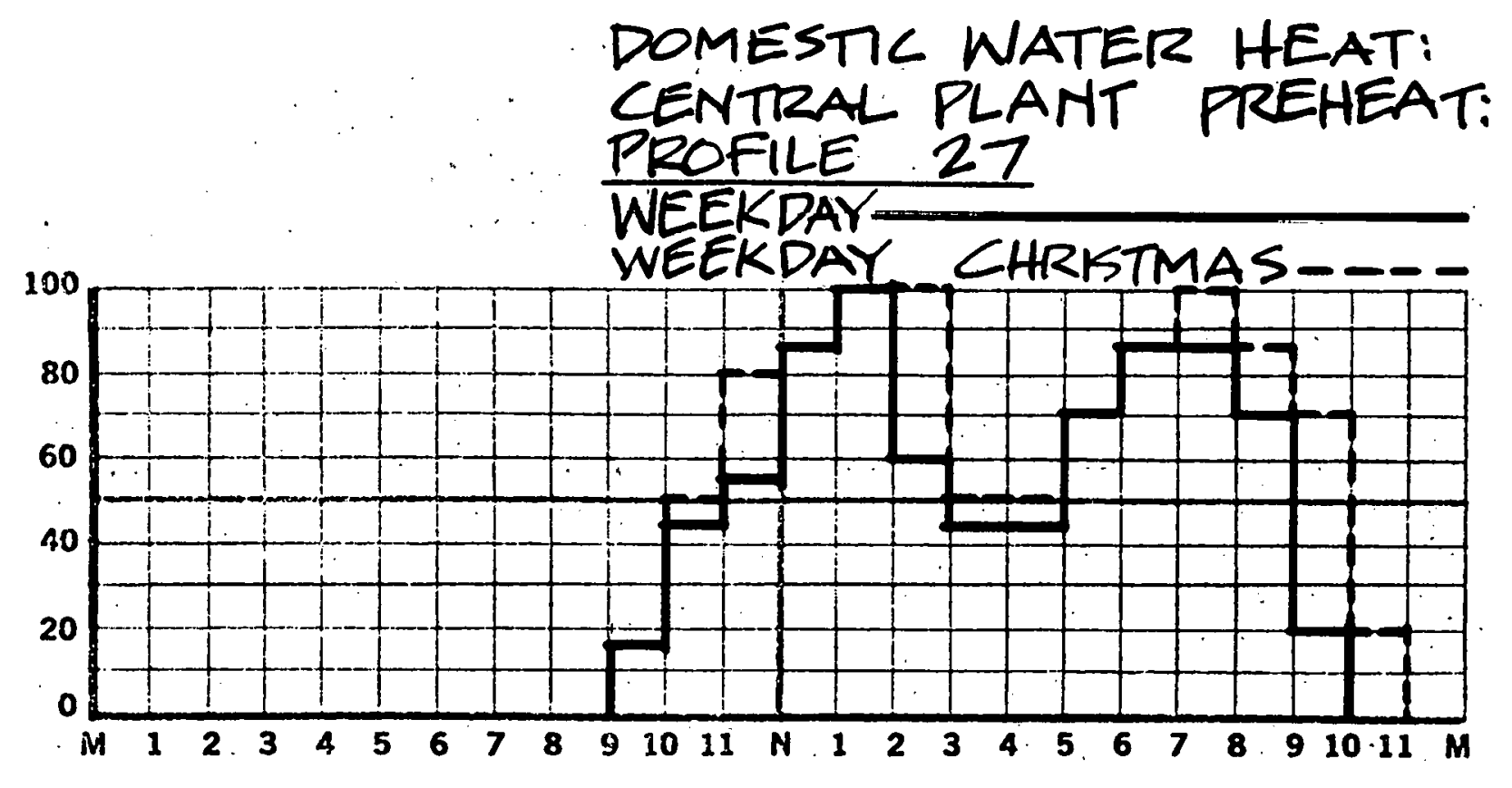

SATLURDAY
SATURDAY CHRSTMAS---

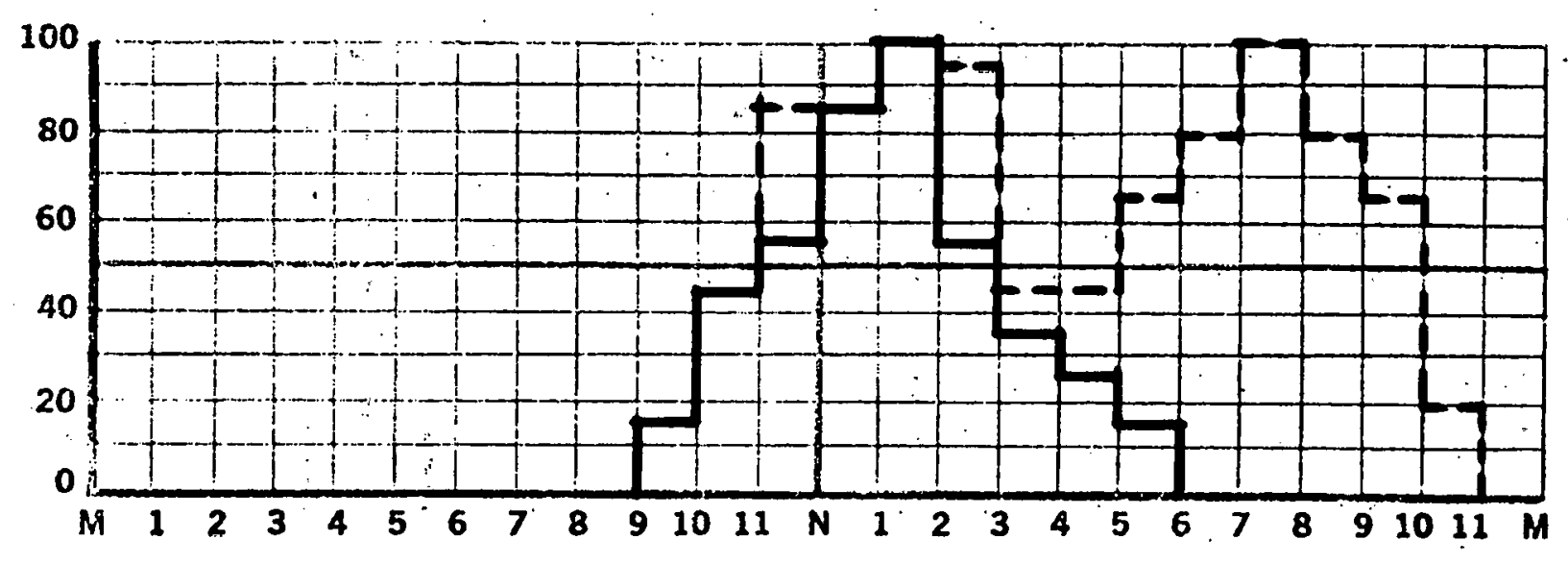


YEARLY TOTAL CONSIMPTION - FOR SCHEME 'F' ONLY (ALL OTHER SCHEMES NOT APPLICABLE TO THIS COMPUTER RUN)

METER SCHEME A SCHEME $B$ SCHEME $C$ SCHEME $C$ STE

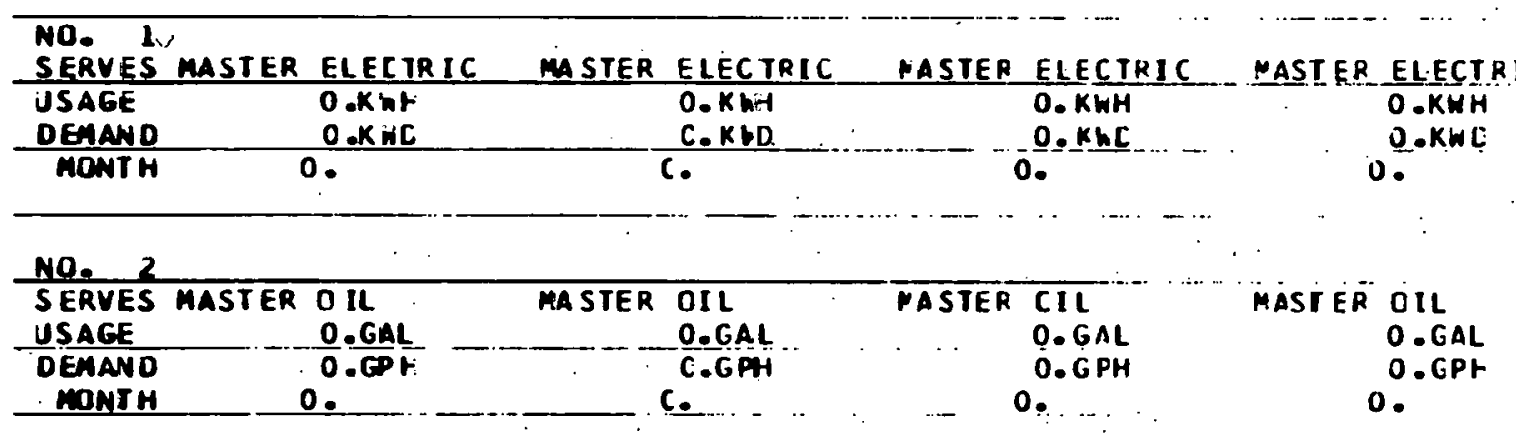

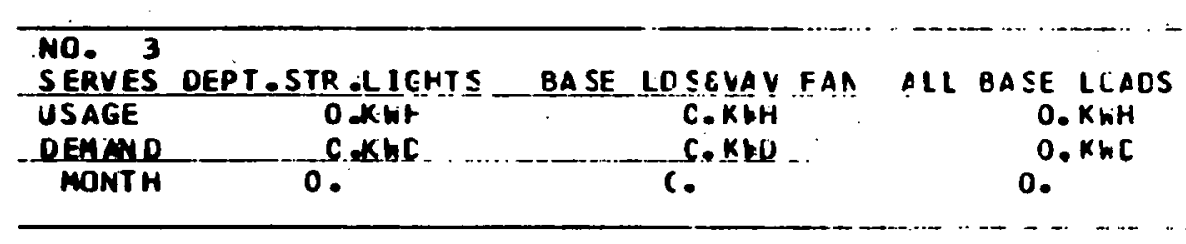

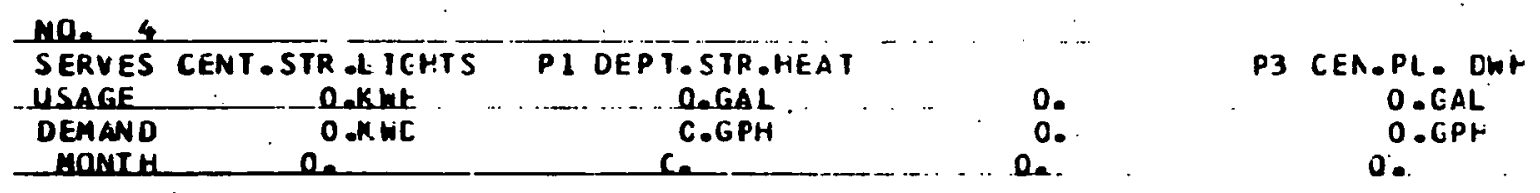
MASTER O IL 0.GAL 3477875 . TON-HRS 0.GPH 2952. ICNS
0 .

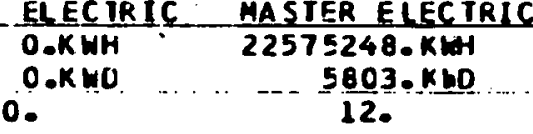

O.KWU 12 .

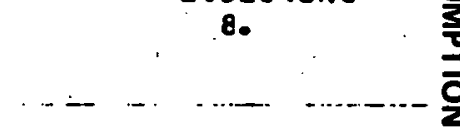

P 2 CEN.PL.HEATG. 756E.MM-BTU 10. PR-BTUA 1.

o.

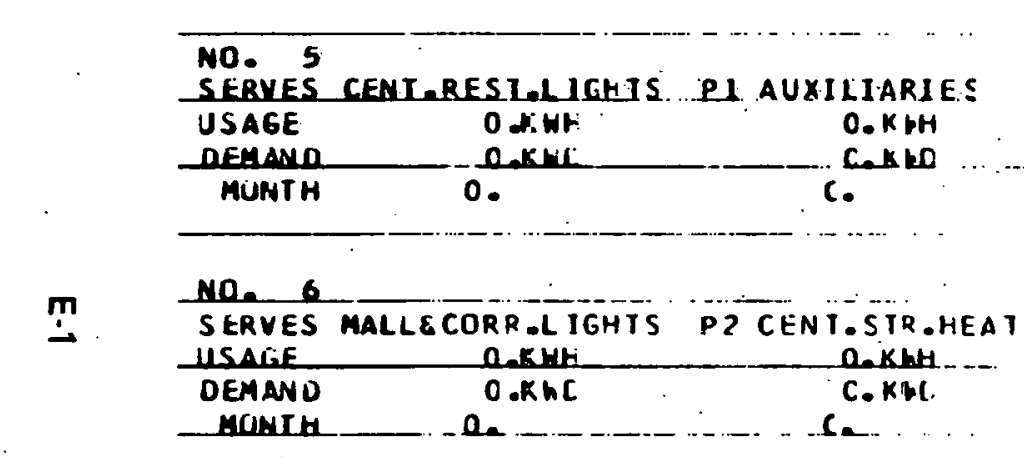

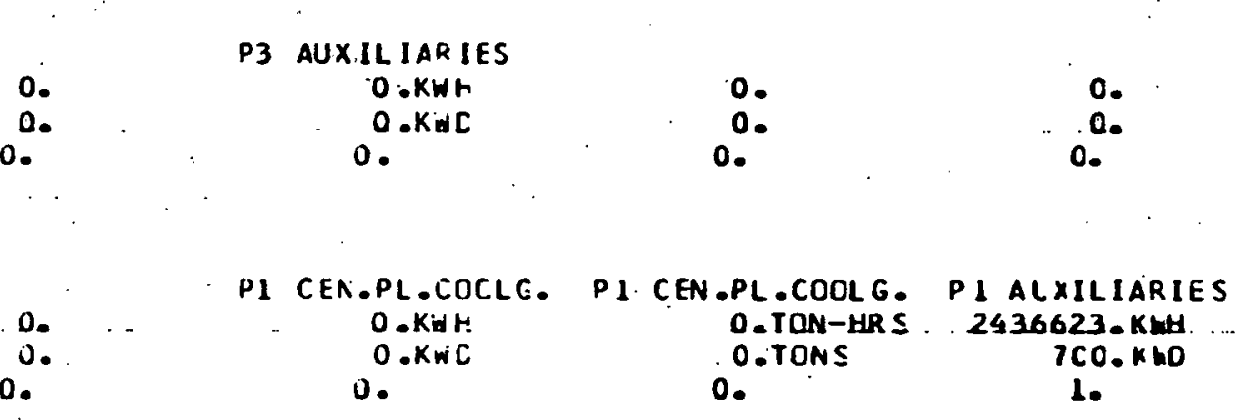
P 3 CEN.PL - OWH 2183856 . AB TL 800.MB TLH o. 0. 


\section{APPENDIX F \\ YEARLY ENERGY CONSUMPTION FOR CONVENTIONAL SYSTEM AND FOR CENTRAL PLANT SYSTEM}

\section{LISTING OF COMBINATIONS OF SCHEMES AND PRIMARY EQUIPMENT SYSTEMS ANALYZED}

(FROM AXCESS COMPUTER RUNS OF FEBRUARY 28 AND MARCH 4, 1976)

\begin{tabular}{|c|c|c|c|c|}
\hline $\begin{array}{c}\text { SCHEME } \\
\text { NO. }\end{array}$ & $\begin{array}{c}\text { PRIMARY } \\
\text { EQUIPMENT } \\
\text { SYSTEM } \\
\text { NO. }\end{array}$ & AREA SERVED & $\begin{array}{l}\text { SYSTEM } \\
\text { USAGE }\end{array}$ & $\begin{array}{l}\text { SYSTEM } \\
\text { TYPE }\end{array}$ \\
\hline $\begin{array}{l}\text { A(1) } \\
\text { With } \\
\text { economizer } \\
\text { cycle } \\
\text { terminal units }\end{array}$ & $\begin{array}{l}P-2 \\
P-3 \\
P-4 \\
P-5 \\
P-6\end{array}$ & $\begin{array}{l}\text { Department } \\
\quad \text { Stores } \\
\text { Center Stores } \\
\text { Center } \\
\text { Restaurants } \\
\text { Common Areas } \\
\text { Office Bldgs. } \\
\text { All Areas }\end{array}$ & $\begin{array}{l}\text { Cooling } \\
\text { Cooling } \\
\text { Cooling } \\
\text { Cooling } \\
\text { Heating }\end{array}$ & $\begin{array}{l}\text { Conventional } \\
\text { Conventional } \\
\text { Conventional } \\
\text { Conventional } \\
\text { Conventional } \\
\text { Central Plant }\end{array}$ \\
\hline $\begin{array}{l}B(2) \\
\text { With } \\
\text { economizer } \\
\text { cycle } \\
\text { terminal units }\end{array}$ & $\begin{array}{l}\text { P-1 } \\
P-2 \\
P-3 \\
P-4 \\
P-5 \\
P-6\end{array}$ & $\begin{array}{l}\text { Department } \\
\text { Stores } \\
\text { Center Stores } \\
\text { Restaurants } \\
\text { Common Areas } \\
\text { Office Bldgs. } \\
\text { All Areas }\end{array}$ & $\begin{array}{l}\text { Heating } \\
\text { Heating } \\
\text { Heating } \\
\text { Heating } \\
\text { Heating } \\
\text { Cooling }\end{array}$ & $\begin{array}{c}\text { Conventional } \\
\text { Conventional } \\
\text { Conventional } \\
\text { Conventional } \\
\text { Conventional } \\
\text { Central Plant }\end{array}$ \\
\hline $\begin{array}{l}C(3) \\
\text { With } \\
\text { economizer } \\
\text { cycle } \\
\text { terminal units }\end{array}$ & $\begin{array}{l}\text { P-1 } \\
\text { P-2 } \\
\text { P-3 }\end{array}$ & $\begin{array}{l}\text { All Areas } \\
\text { All Areas } \\
\text { All Areas }\end{array}$ & $\begin{array}{l}\text { Cooling } \\
\text { Heating } \\
\text { Individual } \\
\text { (separate) } \\
\text { Dom. Water } \\
\text { Heating }\end{array}$ & $\begin{array}{l}\text { Central Plant } \\
\text { Central Plant } \\
\text { Conventional }\end{array}$ \\
\hline $\begin{array}{l}D(4) \\
\text { With } \\
\text { economizer } \\
\text { cycle } \\
\text { terminal units }\end{array}$ & $\begin{array}{l}\text { P-1 } \\
\text { P-2 } \\
\text { P-3 }\end{array}$ & $\begin{array}{l}\text { All Areas } \\
\text { All Areas } \\
\text { All Areas }\end{array}$ & $\begin{array}{l}\text { Cooling } \\
\text { Heating } \\
\text { Domestic } \\
\text { Water } \\
\text { Heating }\end{array}$ & $\begin{array}{l}\text { Central Plant } \\
\text { Central Plant } \\
\text { Central Plant }\end{array}$ \\
\hline
\end{tabular}




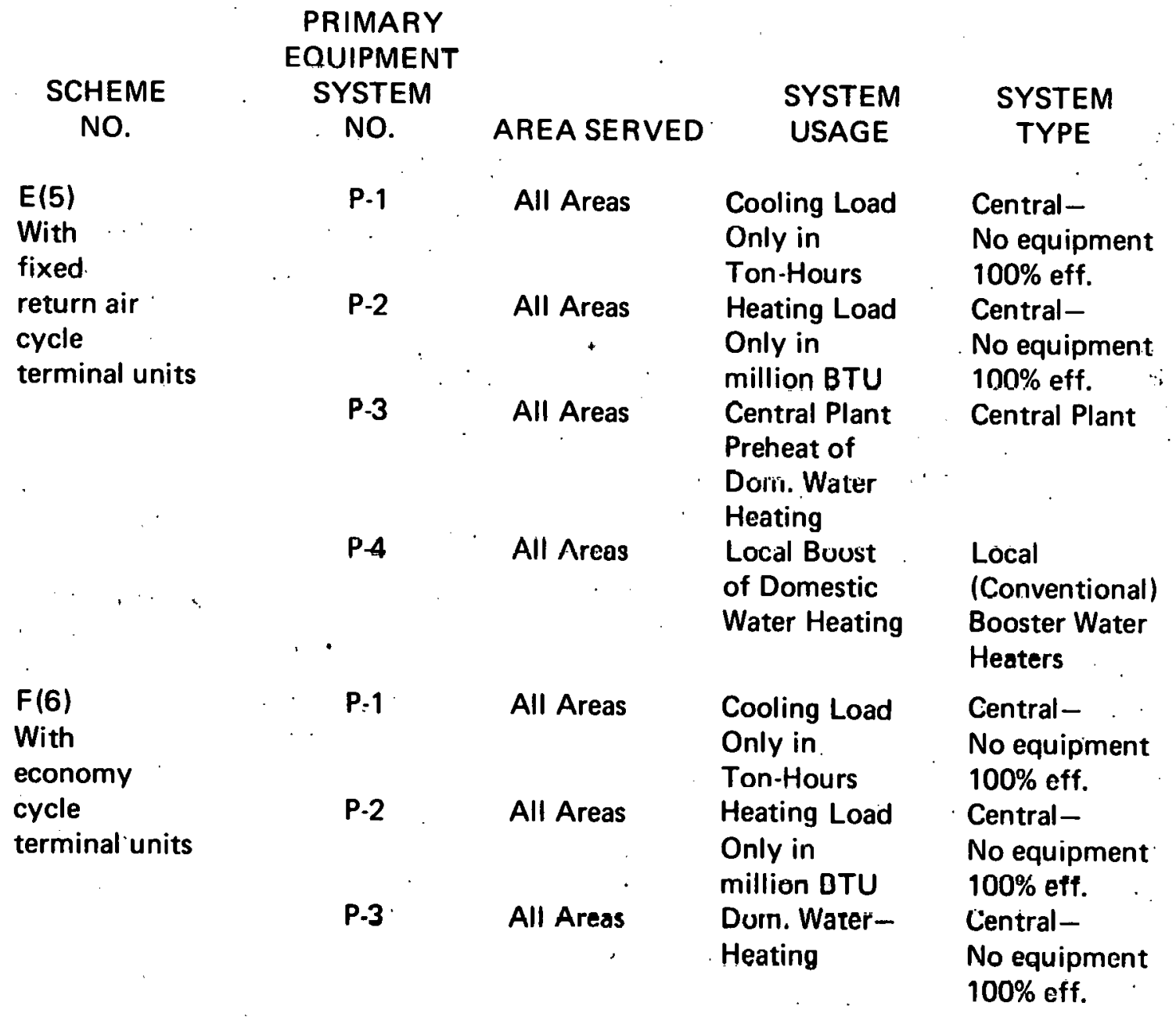




\section{YEARLY ENERGY CONSUMPTION FOR CONVENTIONAL SYSTEM \\ (FROM AXCESS COMPUTER RUN OF FEB. 28, 1976)}

(HEATING VALUE OF PURCHASED ELECTRICITY - 11,760 BTU/KWH)

(HEATING VALUE OF NO. 2 OIL = 139,000 BTU/GAL.)

YEARLY
USAGE

FROM SCHEME A(1)

Master Electric (Meter No. 1)

(includes all Conventional. [local]

Cooling Systems + Central Htg.)

Minus Elec. for Central Htg. Aux.

(Meter No. 34)

Net Total Electric Usage for

Conventional Cooling Systems

PLUS: FROM SCHEME B(2)

Master Oil (Meter No. 2)

(includes oil for Conventional

$\mathrm{Htg}$. Systems only (for Dept.

Stores \& Office Bldgs.)

$$
=29,557,376 \mathrm{KWH}
$$

9320 KWD

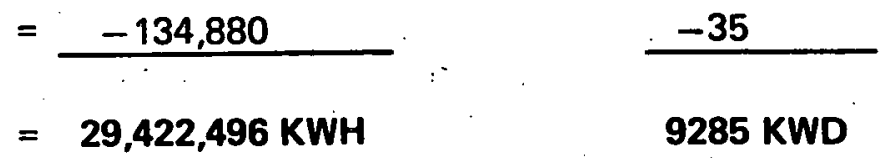

$=$

32,250 Gal.

ELECTRIC USAGE FOR CONVENTIONAL

HTG. SYSTEMS

for Dept. Stores Htg. Aux.

(Meter No. 5)

$=\quad 19,270 \mathrm{KWH}$

5 KWD

for Center [tenant] Stores $\mathrm{Htg}$.

(Meter No. 6)

$=\quad 300,472$

12

for Restaurant Htg. (Meter No. 8)

$=\quad 30,316$

129

for Common Area Htg. (Meter

Nu. 9)

$=\quad 766,703$

591

for Office Bldg. Htg. Aux. (Meter

No. 11)

$=$

19,265

5

Net Total Electric Usage for

Conventional Heating Systems

$=1,136,026 \mathrm{KWH}$

742 KWD 


$\begin{array}{ccc}\text { YEARLY } & \text { YEARLY } & \text { YEARLY } \\ \text { USAGE } & \text { USAGE } & \text { DEMAND }\end{array}$

PLUS: FROM SCHEME C(3)

ELECTRIC USAGE FOR CONVENTIONAL DWH

Total Individual [local]

DWH (Meter No. 13).

$\begin{array}{ll}\text {. 404,180 KWH } & 183 \mathrm{KWD}\end{array}$

Auxiliaries - for above (Meter

No. 14)

$==38,790$.

10

Net total Electric Usage for

Conventional DWH Systems

$=\quad 442,970 \mathrm{KWH}$

193 KWD

Total for Conventional System

$=31,001,492 \mathrm{KWH} \quad 32,250 \mathrm{Gal} .10,220 \mathrm{KWD}$

$31,001,492 \mathrm{KWH} \times \quad 11,760$

$=\quad 364,578 \mathrm{M}^{2}$ BTU/YR.

32,250 GAL $X 139,000$

$=\quad 4,483$

369,061 M² BTU/YR.

3. YEARLY ENERGY CONSUMPTION FOR CENTRAL PLANT SYSTEM

(FROM AXCESS COMPUTER RUN OF FEB. 28, 1976)

FROM CENTRAL PLANT-SCHEME D(4):

$\begin{array}{lll}\text { Total Power (Meter \#1) } & = & 27,828,336 \mathrm{KWH} \\ \text { Total Oil } & = & 87,141 \mathrm{Gal} . \\ 27,828,336 \times 11,760 & = & 327,261 \mathrm{M}^{2} \mathrm{BTU} / \mathrm{YR} \\ 87,141 \times 139,000 & = & \frac{12,113}{339,374 \mathrm{M}^{2} \mathrm{BTU} / \mathrm{YR}} \\ & & \begin{array}{l}\text { Saves } 8 \% \text { of total energy as compared to } \\ \text { Conventional System } \\ \left(29,687 \cdot \mathrm{M}^{2} \mathrm{BTU} / \mathrm{YR}\right)\end{array}\end{array}$


4. COMPARISON OF YEARLY ENERGY CONSUMPTION FOR DOMESTIC WATER HEATING SCHEMES

(FROM AXCESS COMPUTER RUN OF FEB. 28, 1976)

DOMESTIC WATER HEAT - ALL FROM CENTRAL PLANT - SCHEME D(4):

(Meter \#4) $\quad 19,639$.Gal. X 139,000 = 2,730 $\mathrm{M}^{2} \mathrm{BTU} / \mathrm{Y}: \mathrm{R}$

(Meter \#5)

$$
116,366 \mathrm{KWH} \times 11,760=\frac{1,368}{4,098} \mathrm{M}^{2} \mathrm{BTU} / \mathrm{YR}
$$

DOMESTIC WATER - PREHEATED AT PLANT = SCHEME E(5):

(Meter \# 10) $\quad 12,307 . \mathrm{Gal} . \quad \times 139,000=1,711$

(Meter \#11) $\quad 58,185 \mathrm{KWH} \times 11,760=684$

(Meter \# 12).. 120,076 KWH X: 11,760 = 1,412

$($ Meter \# 14) * 38,790 KWH X 11,760 = 456

*From Scheme C $\overline{4,263} \mathrm{M}^{2} \mathrm{BTU} / \mathrm{YR} \quad$ (4\% more than

Central Plant

Scheme above)

INDIVIDUAL (LOCAL) DOMESTIC WATER HEAT - SCHEME C(3):

(Meter \# 13) 404,180 KWH

(Meter \# 14) $\quad 38,790$

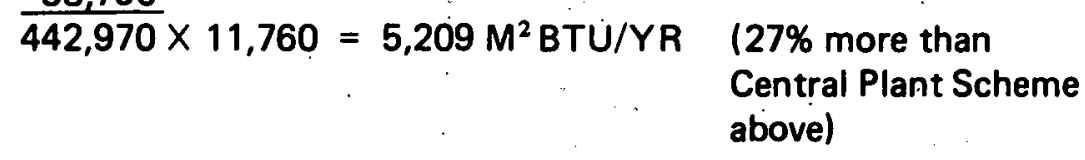




\section{APPENDIX G}

CAPITAL COSTS OF CONVENTIONAL HEATING, AIR CONDITIONING \& DOMESTIC WATER HEATING SYSTEMS

(COSTS INCLUDE EQUIPMENT, LESS AIR HANDLING UNITS, PLUS PIPING INSTALLED, PLUS 15\% MARK-UP \& $11 \%$ ANNUAL ESCALATION)

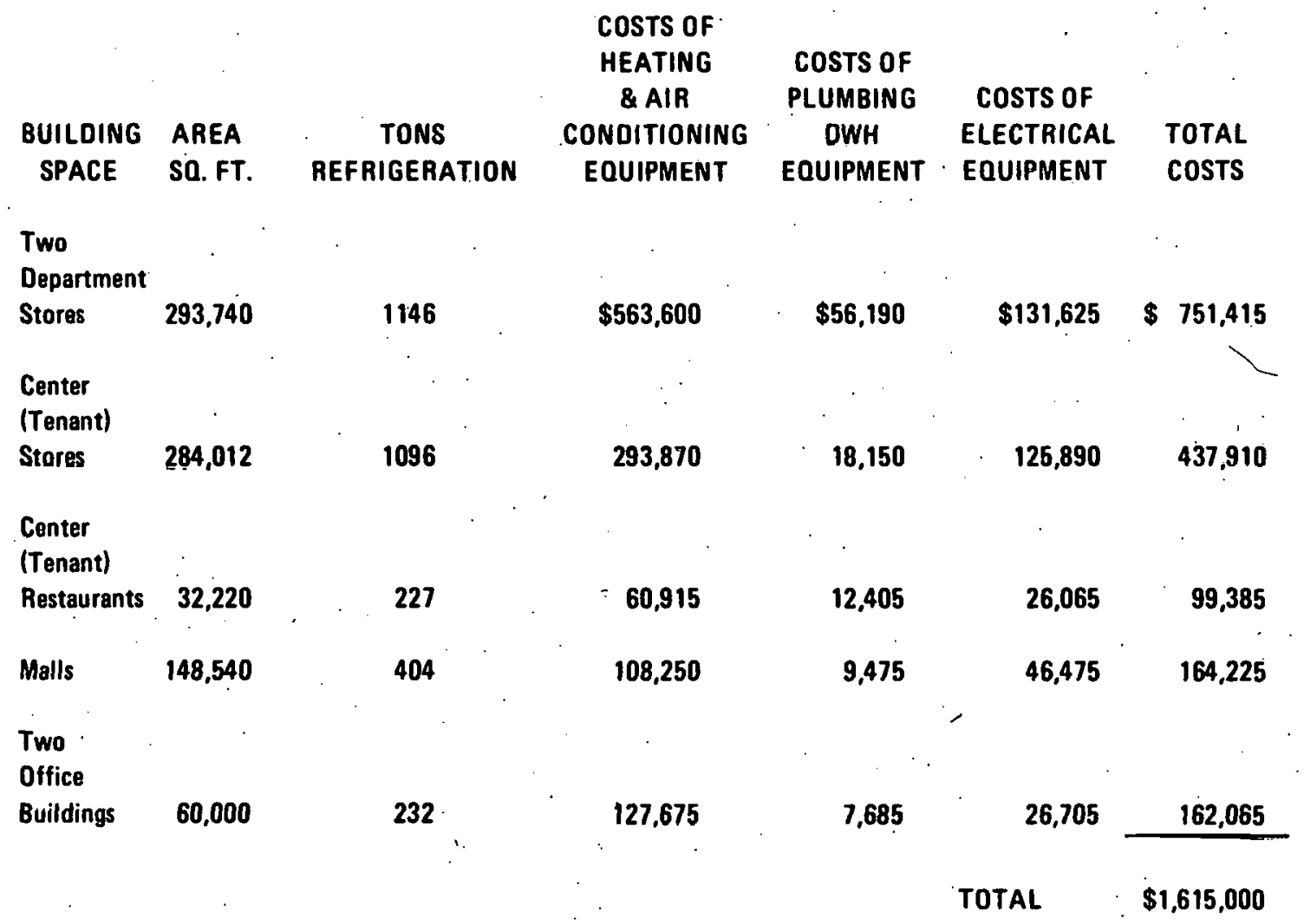




\section{APPENDIX H}

CAPITAL COST ESTIMATE FOR CENTRAL COOLING/HEATING PLANT SYSTEM

MECHANICAL/ELECTRICAL COST

3 - 1000 Ton elec. drive refrig. mach. 3000 Ton cooling tower

2 - Heating Boilers, $300 \mathrm{HP}$

2 - Domestic Hot Water Heaters (Boilers) Auxiliary equipment

Piping

Ventilation \& plumbing Labor \& installation

Plant electrical

$\$ 300,000$

150,000

50,000

20,000

60,000

330,000

50,000

250,000

200,000

Sub-Total

$1,410,000$

Contractor Mark-up \& Escalation

527,000

Sub-Total

$1,037,000$

*Plant Structure including

Utilities and Contingency

490,000

TOTAL PLANT COST

$\$ 2,427,000$

Distribution From Plant To

Site Property Line

40,000

TOTAL

$\$ 2,467,000$

* Assumes integrated structure within parking garage, Parcel $\mathrm{H}$. 


\section{APPENDIX $J$}

\section{CHILLED WATER AND HOT WATER THERMAL STORAGE CALCULATIONS}

\section{CHILLED WATER THERMAL STORAGE CALCULATIONS}

Meter Readings - Cooling BTU $\times 10^{4}$

August 13 - (Maximum Demand Day - from March 4, 1976, AXCESS Calculation . Printout)

$\begin{array}{cc}\text { TIME OF DAY } & \text { LOAD: BTU } \times 10^{4} \\ \text { 10:00 a.m. } & 3,543 \\ \text { 11:00 a.m. } & 3,073 \\ \text { 12:00 Noon } & 2,972 \\ \text { 1:00 p.m. } & 2,951 \\ \text { 2:00 p.m. } & 2,945 \\ \text { 3:00 p.m. } & 3,174 \\ \text { 4:00 p.m. } & 3,064 \\ \text { 5:00 p.m. } & 2,965 \\ \text { 6:00 p.m. } & 3,083 \\ \text { 7:00 p.m. } & 2,902 \\ \text { 8:00 p.m. } & 2,773 \\ \text { 9:00 p.m. } & 1,867 \\ \text { 10:00 p.m. } & 1,524 \\ & 36,816 \times 10^{4} \text { Total BTU Needed } \\ & =30,680 \text { Ton-Hours }\end{array}$

Capacity Required for $14 \mathrm{Hr}$. Operation:

$30,680 / 14-2,191$ Tons

Say 2,190 Tons = 3 Machines @ 730 Tons Ea.

Capacity Required for $16 \mathrm{Hr}$. Operation:

$30,680 / 16=1,917$ Tons

Say 1,920 Tons = 3 Machines @ 640 Tons Ea.

Capacity Required for $20 \mathrm{Hr}$. Operation:

$30,680 / 20=1,534$ Tons

Say 1,560 Tons = 3 Machines @ 520 Tons Ea.

Capacity Required for $24 \mathrm{Hr}$. (Continuous) Operation:

$30,680 / 24=1,278$ Tons

Say 1,290 Tons = 3 Machines @ 430 Tons Ea.

Capacity Required for $13 \mathrm{Hr}$. (No Storage) Operation:

Say 2250 Tons = 3 Machines @ 750 Tons Ea. 
- Chilled Water Storage Required - 14 Hr. Operation

2,191 Tons installed produce $2,629 \times 10^{4} \mathrm{BTU} / \mathrm{Hr}$.

Machine is overloaded entire period from 10:00a.m. through 8:00p.m. (11 hours)

Total BTU withdrawn $=(36,816-1,867-1,524) \times 10^{4}=33,425 \times 10^{4}$

BTU inserted $=11 \times 2,629=28,919$

BTU storage required $=4,506 \times 10^{4} @ 16^{\circ}$ temp. diff. $=338,085$ Gals.

Say $=370,000$ Gals.

- Chilled Water Storage Required - 16 Hr. Operation

1,920 Tons installed produce 2,304 BTU/Hr. $\times 10^{4}$

Machine is overloaded: 10:00a.m. in 8:00p.m. (11 hours)

BTU withdrawn $=33,425 \times 10^{4}$

BTU inserted $=11 \times 2,304=25,344 \times 10^{4}$

BTU storage required $=33,425-25,344=8,081 \times 10^{4} @ 16^{\circ}$ temp. diff. $=606,317$ Gals.

Say $=650,000$ Gals.

- Chilled Water Storage Required - 20 Hr. Operation

1,534 Tons installed produce $1,841 \times 10^{4} \mathrm{BTU} / \mathrm{Hr}$.

Machine is overloaded: 10:00a.m. through 9:00p.m. (12 hours)

BTU withdrawn $=36,916-1,521=35,292 \times 10^{4}$

BTU inserted $=12 \times 1,841=22,092 \times 10^{4}$

BTU storage required=13,200 $\times 10^{4}$ BTU @ 16 $6^{\circ}$ temp. diff. $=990,400$ Gals.

Say $=1,100,000$ Gals.

\section{- Chilled Water Storage Required - 24 Hr. Operation}

1,278 Tons required produce 1,534 BTU/Hr.

Machine overloaded: 10:00a.m. through 9:00p.m. (12 hours)

BTU withdrawn $=35,292 \times 10^{4}$

BTU inserted $=12 \times 1,534=18,403 \times 10^{4}$

BTU storage required $=16,889 \times 10^{4}$ BTI $@ 16^{\circ}$ tọmp. diff. $-1,267,000$ Gals:

S̄ay $=1,400,000$ Gals. 


\section{HOT WATER THERMAL STORAGE CALCULATIONS}

The hot water heating storage tank sizes and capacities were based upon the required number of gallons to hold the waste heat output of one prime mover for a two-hour period, when heated from $140^{\circ} \mathrm{F}$ to $200^{\circ} \mathrm{F}$.

An example for Scheme 1B follows:

Waste heat from one prime mover (diesel engineer generator)

$=13,140,000 \mathrm{BTU} / \mathrm{Hr}$.

$\frac{2 \times 13,140,00 \mathrm{BTU} / \mathrm{Hr}}{833 \times 60^{\circ}}=52,580$ Glas. Say $=53,000$ Gals.

$8.33 \times 60^{\circ}$ 


\section{APPENDIX K}

\section{SUPPLEMENTAL SYSTEMS}

\section{SOLAR ENERGY SYSTEM}

Solar energy was evaluated to serve the domestic hot water load of the energy community. This load was calculated by the AXCESS program to be 2,184,000 MBTU/YR. The system evaluated would provide $1,115,000 \mathrm{MBTU} / \mathrm{YR}$ with approximately 4,000 square feet of collector area, at $130^{\circ}$, with a 5600 gallon storage tank.

The capital cost of the system, including piping and storage was estimated at $\$ 35$ / square foot of collector area, or $\$ 140,000.00$.

The system evaluated represents an annual fuel savings of approximately 8,000 gallons of oil, representing an annual cost savings of approximately $\$ 2,700.00$.

Assuming an annual operating and maintenance cost of $5 \%$ of invested capital added to the owning cost, the solar energy system does not represent an economically feasible supplemental system for any of the schemes considered.

The impact of the solar system evaluated on air quality is a reduction of approxlmately $0.2 \%$ in emitted pollutants.

\section{SOLID WASTE INCINERATOR WITH HEAT RECOVERY}

This system was evaluated on the basis of providing low grade BTU's for space cooling by absorption refrigeration.

Analysis of solid waste loads from the energy community indicated that a 2,000 lb/hr. controlled air incineretor was required. This system provides $104 \mathrm{MBTU} / \mathrm{Day}$ at 15 psi, representing approximately $20 \%$ of the peak day energy requirement for cooling.

As a trial, Scheme 1E was evaluated for comparative economics. The capital cost of the incinerator, piping, stack and heat exchanger was estimated at $\$ 300,000.00$. The reduction in cost from Scheme $1 E$ for the reduction in size of the prime mover and prime mover heat recovery is $\$ 390,000$ indicating a capital cost savings of $\$ 90,000.00$ for using the incinerator. However, this does not include the cost of equipment to transport the waste from the energy community to the plant. A pneumatic chute delivery system with 3 stations ( 2 at the retail center, 1 at the office complex). was evaluated. The estimated cost of $\$ 220,000$ for this system was determined not economically justified and delivery of the waste was assumed to be done by cart train. 
For the particular example chosen, the incinerator system actually increased the amount of fuel consumed by approximately $15 \%$. On an hourly basis, the calculation for this is as follows:

With Incinerator

8. MBTU/HR input from incinerator reduces power generation by $1,914 \mathrm{KWH}$ (at $4.18 \mathrm{lb} / \mathrm{KW}$ recovery rate).

Additional 1,914. $\mathrm{KWH}$ from grid at $11,760 \mathrm{BTU} / \mathrm{KWH}=$ 22,508,000 BTU

plus $1,000,000 \mathrm{BTU}$ input fuel to incinerator $\underline{\underline{23,508,000 ~ B T U}}$

Without Incinerator

\section{$1,914 \mathrm{KWH} \times 10,600 \mathrm{BTU} / \mathrm{KWH}=20,288,000 \mathrm{BTU}$}

A similar calculation for the combustion turbine scheme indicated a negligible impact on fuel consumption with or without the incinerator.

The annual maintenance and operating cost of the incinerator would substantially increase overall plant cost because of the personnel which would have to be assigned to haul the waste, charge the incinerator and remove residual ash. A minimum of $\$ 50,000$ was estimated for annual operating and maintenance cost. A net savings in cost for removal of the solid waste to landfill was estimated at $\$ 10,000.00$ annually.

An evaluation of the incinerator's impact on air quality indicated that with venturi type scrubbers for removal of particulates, the incinerator would comply with existing air quality standards. $\mathrm{SO}_{x}$ emissions, compared to equivalent BTU of oil burned, could be reduced by one-half. However, since the City of Pasadena is located in an area which experiences particularly bad smog problems, it is difficult to determine whether approval to build or operate an incinerator can bo obtained from the Southerm California Air Pollution Control District.

Since the addition of an incinerator does not conserve energy, and in fact for some of the TIES schemes actually increases fuel consumption, and since the relatively high operating and maintenance cost precludes economic feasibility, the use of a heat recovery incinerator as a supplemental system is not recommended. 


\section{APPENDIX L \\ STATEMENT OF ARCHITECT-ENGINEER SERVICES}

The Architect-Engineer will undertake the following specific tasks under Scope of the Work. The work shall be performed so as to satisfy the requirements of both the Agency and ERDA as set forth in Prime Contract No. EY-76-C-03-1151.

The Architect-Engineer will prepare a feasibility study and report for a total energy plant which will serve an initial development of approximately $825,000 \mathrm{sq}$. $\mathrm{ft}$. of commercial and office space plus parking structures. After completion of the study, the Architect-Engineer will prepare construction documents for a plant with the chosen system.

I. Load analysis to determine the most feasible and practical system for project including:

A. Load simulation analysis for the following services using computer programming to the maximum feasible extent should be provided.

\section{1. heating}

2. cuuling

3. lighting

4. electrical, other than lighting

5. domestic hot water.

6. cooking

7. liquid and solid waste treatment

8. vertical and lateral transportation of goods and people

9. other services

NOTE: Information on proposed developments such as size, occupancy, location, hours of operation, etc. is to be provided by Project Manager. Time load profiles will be developed on hourly, daily, monthly and seasonal basis for all service and all energy forms necessary to satisfy the services. For services that computer programming are not available for simulation, the load analysis and the time-load characteristics should be determined from known or readily desirable relationships and experienced-based data.

In developing the base data for the study, the Architect-Engineer will investigate all other related studies and activities, including the MIUS program, which may have an application to this study so that maximum available relevant data will be utilized for the development of these tasks. 


\section{Integrated Systems Alternatives}

A. The data developed under Task I will be the basis of the analysis of the various integrated systems alternative. Develop a matrix interfacing the services requirements as Task $I$ and the following energy converters and energy sources.

ENERGY SOURCES

oil

gas

coal

solid waste

sewage sludge

solar unurgy

others

\section{ENERGY CONVERTERS}

steam turbine

diesel engine

combustion turbine

combined cycle (combustion turbine-steam turbine)

externally-fired closed Brayton cycle

Lurgi process gasilied coal

Гluidizèd bed burning

Thermal storage

Others

The operating characteristics of the energy convertors will be compared to the services required for the determination of the optimum combination of supply and demand and the determination of the optimum system. Computer analysis should be used to the maximum feasible extent in this synthesis and the evaluation of the cycle characteristics in conjunction to services to be provided.

B. Analysis of existing technology available (Resource research). This analysis should be performed parallel to the work for IIA. Analysis should be performed for operating data, equipment availability, cost, reliability, maintenance, and other pertinent dàta. Various equipment and engineering systems manufacturers should be contacted to determine previous data and other pertinent data necessary for the following analysis configuration.

C. Analysis configuration of all viable alternatives from above including distribution system of resulting energy forms. A viable alternative is defined as nne that will employ technologies that are within the state-of-the-art. However, modest advances of new applications of existing technologies should bc the goal for eacil alternative.

1. Procurement cost and energy analysis of each combination

2. Inter-combination comparisons and separate predictions based on:

a. unit capital cost

b. unit total annual owning and operating costs

c. energy cunsumed

d. heat recovered 

e. environmental impact
f. project reliability
g. flexibility
h. construction schedule
i. electrical integration with utility

At the end of this step, the three top contenders should be selected for further evaluation and analysis as follows. Each of the three top contenders should meet the following criteria:

1. The estimated cost of the system to be close to established budget limits.

2. The overall system will maximize conservation of energy and maximize use of replenishable forms of energy such as solar, trash, etc.

3. The system will meet the latest environmental standards.

4. The system will be adaptable to incremental expansion and integration with existing and now facilities and systems.

NOTE: Project Manager to furnish all established budget limits

D. Analysis and feasibility of incremental expansion beyond the first designed area.

1. Delineation of area of energy community of potential customers, feasibility of incremental expansion, etc.

NOTE: Project Manager to assist in determining possible future market considerations for expansion of system including increments and ultimate capacity.

E. Analysis and selection of location of facility taking into consideration energy community, incremental expansion, distrlbution system, plant size, environmental problems, traffic and parking interaction with existing power distribution, etc.

NOTE: Project Manager to assist in site evaluation process.

F. Comparison of three alternatives with conventional systems in the same elements (C. $2, a, b, c, d, e, f, g, h, i)$. The conventional system will be energy conserving systems for each building.

NOTE: Project Manager will assist in identification of conventional system. 
G. Provide technical assistance to Project Manager in analysis and resolution of problems related to interfacing and integrating the proposed systems with existing and proposed facilities with respect to:

1. space layout

2. aesthetics

3. $\quad$ site work

4. underground piping

5. existing utilities

6. electrical system

7. construction phasing

H. Prelimiirary test of design methodolugy of the three viable alternatives to include:

1. simplified flow schematic

2. general plant arrangement

3. one-line electrical schematic

At the end of this phase the Agency and the City will choose one system for further development of a design package as desrrihed subecquently.

I. A cunclse, comprehensive report should be prepared by the Architect-Engineer for publication containing all data and work that was develuped during Tasks I and II. This report should be sultable for publication and distribution for the widest dissemination gained in this work and will include the methodology used to determine the optimum system. Submission will be made by the ArchitectEngineer of the master original as approved by the Agency plus 20 copies. 